\title{
DESENVOLVIMENTO DE UMA CÂMARA DE COMBUSTÃO PARA UM MOTOR DIESEL OTTORIZADO AUXILIADO POR SIMULAÇÃO 1D / 3D.
}

\author{
SANDRO GUIMARÃES SOUZA
}

Exemplar apresentado a Escola de Engenharia de São Carlos da Universidade de São Paulo, como parte dos requisitos para defesa de tese de doutoramento em Engenharia Mecânica.

ORIENTADOR: Prof. Dr. Josmar Davilson Pagliuso.

São Carlos

2014 
AUTORIZO A REPRODUÇÃO TOTAL OU PARCIAL DESTE TRABALHO, POR QUALQUER MEIO CONVENCIONAL OU ELETRÔNICO, PARA FINS DE ESTUDO E PESQUISA, DESDE QUE CITADA A FONTE.

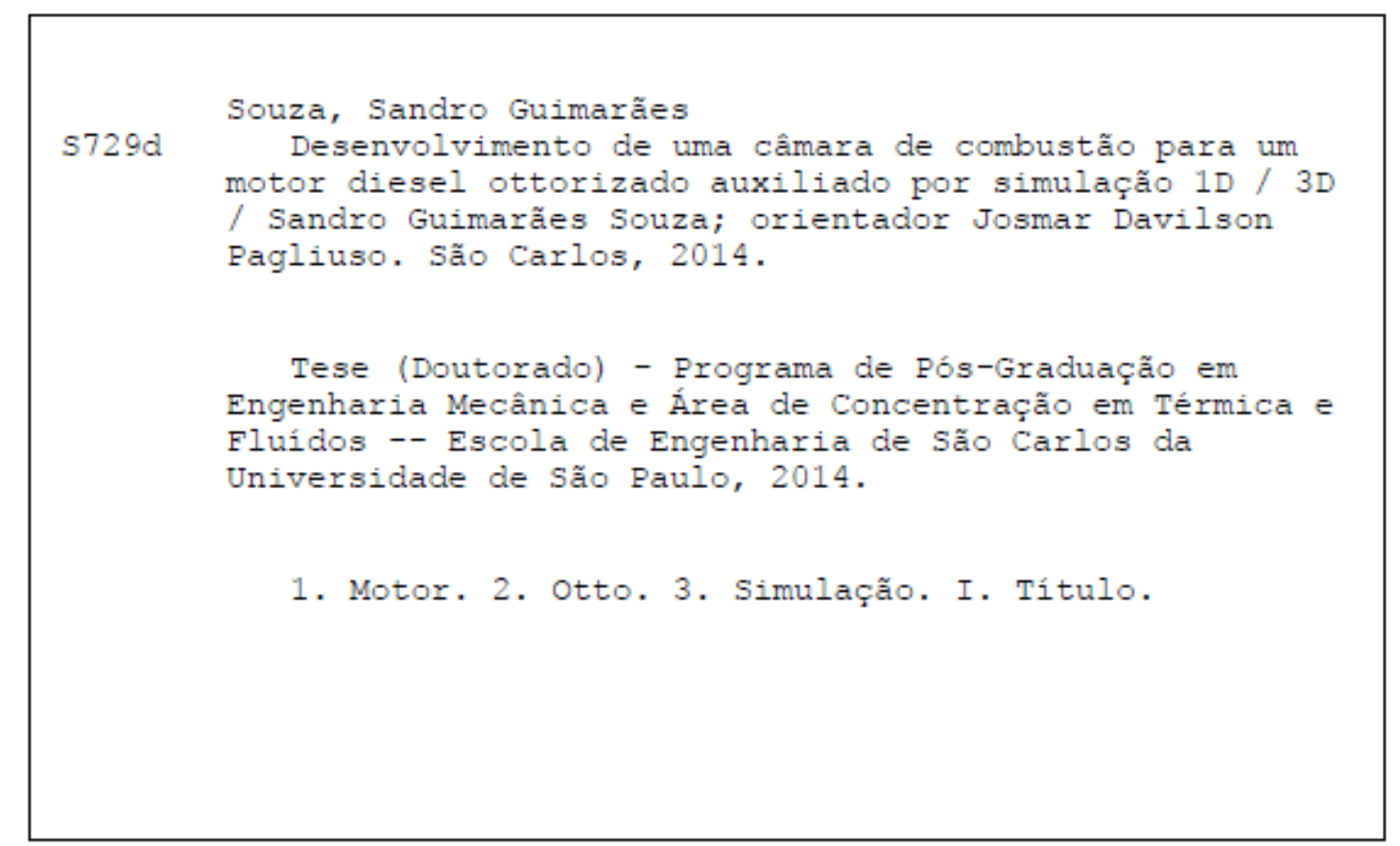




\section{FOLHA DE JULGAMENTO}

Candidato: Bacharel SANDRO GUIMARÃES SOUZA.

Título da tese: "Desenvolvimento de uma câmara de combustão para motor diesel ottorizado auxiliado por simulaçāo nld/3d".

Data da defesa: $23 / 05 / 2014$

Comissäo Julgadora:

Prof. Dr. Josmar Davilson Pagliuso (Orientador)

(Escola de Engenharia de São Carlos/EESC)

Prof. Dr. Antonio Moreira dos Santos

(Escola de Engenharia de Săo Carlos/EESC)

Prof. Dr. Mario Eduardo Santos Martins

(Universidade Federal de Santa Maria/UFSM)

Prof. Dr. Felipe Soto Pau

(Universidade Federal de Sāo Joāo del-Rei/UFSJ)

Prof. Dr. Márcio Turra de Ávila

(Universidade Federal de Sāo Carlos/UFSCar)
Resultado:
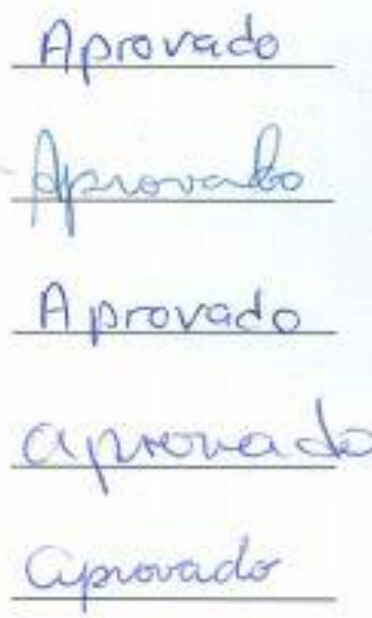

Coordenador do Programa de Pós-Graduaçăo em Engenheira Mecânica: Prof. Associado Marcelo Areias Trindade

Presidente da Comissāo de Pós-Graduaçăo:

Prof. Titular Denis Vinicius Coury 



\section{AGRADECIMENTOS}

A Jesus Cristo, meu Senhor.

Ao Prof. Dr. Josmar Davilson Pagliuso (EESC).

Ao Prof. Dr. Antônio Moreira dos Santos (EESC).

Ao Prof. Dr. Felipe Soto Pau (UFSJ).

Ao Prof. Dr. Mário Eduardo Santos Martins (UFSM).

Ao Prof. Dr. Márcio Turra de Ávila (UFSCar).

Ao Prof. Dr. Fernando Milioli (EESC).

Ao D. Sc. José Eduardo Oliveira, pela grande contribuição no trabalho de simulação 3D.

Ao Msc. Giovanni Kotinda, pela contribuição no trabalho experimental.

Ao Engenheiro Venício Nascimento, pela contribuição no trabalho experimental.

Ao Técnico Mecânico Sandro Ortega Pereira, pela contribuição em teste dinamométrico.

Ao $\mathrm{CNPq}$ (Conselho Nacional de Desenvolvimento Científico e Tecnológico), pelo imenso apoio ao desenvolvimento desta obra. 


\section{SUMÁRIO}

$1 \quad$ Introdução 1

2 Motores de Combustão Interna do Ciclo Otto 2

3 Processo de Formação da Mistura Ar-Combustível 6

3.1 Volatilidade 7

3.2 Tipo de Mistura 8

3.2.1 Motor de Mistura Homogênea____ 8

3.2.2 Motor de Carga Estratificada____ 9

3.2.3 Efeito das Condições Operacionais Sobre o Requisito de Mistura ___ 9

3.3 Dinâmica da Admissão ___ _ _ _ 11

3.3.1 Influência do Coletor de Admissão ___ 11

3.3.2 Influência do Duto de Admissão do Cabeçote ____ 14

3.3.3 Influência da configuração da válvula de admissão ___ 19

4 Formação da Mistura Ar-Combustível na Câmara de Combustão _ 24

4.1 Área de Compressão e Resfriamento (Squish e Quench) ___ 24

4.2 Relação Superfície / Volume ___ 25

4.3 Relação Curso / diâmetro___ 26

5 A Combustão nos Motores de Ignição por Centelha__ 28

5.1 Velocidade e Percurso da Frente de Chama, Taxa de Queima e Desenvolvimento de Pressão 30 
5.1.1 Efeito da Rotação do Motor ___ 31

5.1.2 Efeito da Pressão de Admissão ___ 31

5.1.3 Efeito da Razão entre as Pressões de Descarga e Admissão ___ 32

5.1.4 Efeito da Relação Combustível / Ar___ 32

5.1.5 Efeito do Número e Posições das Velas de Ignição na Câmara de Combustão ___ 33

5.2 Pré-Ignição ___ 35

5.3 Detonação ___ 36

5.4 Emissões de Poluentes ___ 37

5.5 Influência da Câmara de Combustão Sobre a Performance e Emissões do Motor 39

$6 \quad$ Estado da Arte das Câmaras de Combustão 49

6.1 Aspéctos Gerais dos Projetos das Câmaras de Combustão 49

6.1.1 Câmara Tipo "T" _ _ 49

6.1.2 Câmara Tipo "L" 50

6.1.3 Câmara Tipo "F" ___ 51

6.1.4 Câmara Tipo Coração ___ 52

6.1.5 Câmara Tipo Banheira no Pistão (Cabeçote Plano) ___ 54

6.1.6 Câmara de Combustão Tipo Cunha (Wedge Chamber) ___ 55

6.1.7 Câmara de Combustão com Câmara Auxiliar ___ 56

6.1.8 Câmara de Combustão May Fireball ___ 58

6.1.9 Câmara de Combustão Hemisférica____ 59

6.1.10 Câmara de Combustão para Motor de Queima Pobre ___ 63

6.2 Câmara de Combustão para Motor Assistido por Injeção Direta de Combustível 65

6.2.1 Requisitos do Sistema de Injeção GDI___ 67

6.2.2 Geometria da Câmara de Combustão___ 68

6.2.3 Estratégias Básicas para Formação da Mistura __ 71

6.3 Resumo dos Requisitos de uma Câmara de Combustão para Motores ICE___ 73

$7 \quad$ Modelamento $1 D$ 
7.1 Modelo 1D de Duas Zonas e Grandezas Envolvidas 75

7.1.1 Taxa de Queima (Heat Release) _ 75

7.1.2 Taxa de Liberação de Calor (Heat Release Rate) __ 75

7.1.3 Taxa de Liberação de Calor Aparente (Apparent Heat Release Rate)___ 76

7.1.4 Taxa de Queima Aparente (Apparent Burn Rate) ___ 76

7.1.5 Combustão Preditiva (Predictive Combustion) ___ 76

7.1.6 Combustão Não-Preditiva (Non-Predictive Combustion) ___ 76

7.1.7 Descrição do Método de Combustão por Duas Zonas___ 77

7.1.8 Modelo de Wiebe (Spark-Ignition Wiebe Model)___ 79

7.2 Modelo de Chama Turbulenta (Spark-Ignition Turbulent Flame Model) __ 81

7.3 Análise por Três Pressões (Three Pressure Analysis (TPA)) ___ 82

7.4 Modelo de Combustão por Múltiplas Zonas (Multi-Zone Combustion) ___ _ 86

$8 \quad$ Modelamento 3D de Combustão (CFD)___ 87

8.1 Combustão com chama Pré-Misturada (Premixed Combustion)

8.1.1 Limitações_____ 87

8.1.2 Modelo de Zimont___ 88

8.1.3 Propagação da Frente de Chama ____ 88

8.1.4 Velocidade de Chama Turbulenta ___ 89

8.1.5 Cálculo da Temperatura Adiabática ___ 90

8.1.6 Cálculo da Temperatura Não-Adiabática ___ 91

8.1.7 Cálculo da Densidade ___ 91

8.1.8 Modelo de Ignição (spark)___ 92

8.2 Modelo de Combustão com Chama Não Pré-Misturada ___ 92

9 Setup do Código CFD

9.1 Solver ___ 94

$10 \quad$ Materiais e Métodos _ 98 
10.1 Simulação 98

10.2 Etapa Experimental 99

10.2.1 Motor de Pesquisa FEV 99

10.2.2 Análise de Fluxo (PIV) 109

10.2.3 Bancada de "Spray" 111

10.2.4 Consumo de Combustível 112

11 Fase de Aprendizado 114

11.1 Simulação de fluxo Não Reativo e combustão para o Ciclo Otto 114

11.2 Simulação para o Ciclo Diesel 122

12 Fase de Desenvolvimento 130

12.1 Desenvolvimento da Câmara de Combustão 130

12.1.1 Simulação de Escoamento Não Reativo 130

12.1.2 Simulação da Combustão 136

12.1.3 Análise Experimental das Câmaras de Combustão "Chapéu Mexicano" e "Baseline”._ 149

12.1.4 Análise da Formação da Mistura Ar/Combustível (simulação 3D) 153

13 Conclusões 174

14 Propostas Para Trabalhos Futuros 175

15 Bibliografia 176

15.1 Bibliografia Referenciada 176

15.2 Bibliografia Consultada 180 


\section{LISTA DE FIGURAS}

Figura 01 - Diagrama de válvulas. (SANTOS, 2000) 3

Figura 02 - Cabeçotes em T, F, L, I. (RINSCHLER e ASMUS, 1995). 5

Figura 03 - Coletor de comprimento variável (HEISLER, 1995). 12

Figura 04 - Coletor de diâmetro variável (HEISLER, 1995). 13

Figura 05 - Comparação entre um coletor de comprimento continuamente variável e um convencional (LENZ, 1992). 14

Figura 6 - Duto de admissão helicoidal para geração de FRH (swirl) (HEISLER, 1995). 15

Figura 7 - Fluxo Rotacional Vertical (HEISLER, 1995). 16

Figura 08 - Duto de admissão de fluxo direto (HEISLER, 1995). 17

Figura 9 - Duto de admissão de parede semicircular (HEISLER, 1995). 17

Figura 10 - Duto de admissão com válvula restrita (HEISLER, 1995). 18

Figura 11 - Duto de admissão com paredes de deflexão (HEISLER, 1995). 19

Figura 12 - Diferentes combinações de múltiplas válvulas de admissão restritas (LEE, 1938). 21

Figura 13 - Geração de FRH por meio de válvula auxiliar (AUTOMOTIVE ENGINEER, 1977). 22

Figura 14 - Duto de admissão variável (AUTOMOTIVE ENGINEERING, 1987). 23

Figura 15 - Área de compressão (HEISLER, 1995). 25

Figura 16 - Relação superfície-volume (HEISLER, 1995). 26

Figura 17 - Regiões da câmara de combustão (JUDGE, 1965). 29

Figura 18 - Efeito da relação combustível / ar no avanço da centelha e performance do motor (GERRISH e VOSS, 1940).

Figura 19 - Efeito do número e posições das velas de ignição sobre a performance do motor (MARVIN et al., 1935). 34

Figura 20 - Efeito da relação ar-combustível sobre os fenômenos de pré-ignição e detonação (MOGI et al., 1998).

Figura 21 - Influência da temperatura do cabeçote sobre o fenômeno de detonação, para misturas ricas e pobres (SANDERS e PETERS, 1945).

Figura 22 - Controle de emissões (http://www.ambiente.sp.gov.br).

Figura 23 - Efeito da rotação sobre o requisito de octanas (CARIS et al., 1956).

Figura 24 - Influência do requisito de octanas sobre o tempo de queima, temperatura e pressão do gás na zona extrema (CARIS et al., 1956).

Figura 25 - Efeito da geometria da câmara de combustão sobre o período de queima (CARIS et al., 1956).42

Figura 26 - Efeito do gap na área de compressão sobre o requisito de octanas (CARIS et al., (1956).43

Figura 27 - Área de compressão inclinada e plana (UEDA et al., 1999). 
Figura 28 - Efeito da área de compressão inclinada sobre a performance do motor (UEDA et al., 1999). 45

Figura 29 - Efeito da localização da área de compressão (FUJIMOTO et al., 2002). 46

Figura 30 - Câmara tipo “T” (MALEEV, 1945).

Figura 31 - Câmaras tipo "L" de baixa turbulência (a) e alta turbulência (b) (MALEEV, 1945). 51

Figura 32 - Câmara tipo "F” (JUDGE, 1965).

Figura 33 - Câmara em forma de coração (HEISLER, 1995). 53

Figura 34 - Câmara tipo banheira no pistão (HEISLER, 1995). 54

Figura 35 - Câmara de combustão tipo cunha (HEISLER, 1995). 56

Figura 36 - Câmara de combustão com câmara auxiliar (LENZ, 1992).

Figura 37 - Câmara do Porsche SKS com injeção mecânica (LENZ, 1992). 57

Figura 38 - Câmara de combustão May fireball (HEISLER, 1995). 58

Figura 39 - Câmara hemisférica de três válvulas (HEISLER, 1995). 60

Figura 40 - Efeito do número de válvulas sobre a performance do motor (HEISLER, 1995). 62

Figura 41 - Câmara hemisférica de quatro e cinco válvulas (HEISLER, 1995). 62

Figura 42 - Câmara com duas velas de ignição (HEISLER, 1995). 65

Figura 43- Motor Benz 300 SL (ZHAO et al., 1999). 70

$\begin{array}{ll}\text { Figura } 44 \text { - Câmaras de combustão GDI (ZHAO et al., 1999). } & 71\end{array}$

Figura 45 - Fluxo Rotacional Vertical Reverso (reverse tumble) (ZHAO et.al., 1999). 72

Figura 46 - Comparativo de "heat release". $\quad 80$

$\begin{array}{ll}\text { Figura } 47 \text { - Comparativo de "burn rate". } & 81\end{array}$

Figura 48 - Calibração do modelo 1D.

Figura 49 - Simulação de uma combustão anormal.

Figura 50 - Resultados experimentais de uma combustão anormal. 85

Figura 51 - Método segregado.

Figura 52 Método acoplado. $\quad 96$

$\begin{array}{lr}\text { Figura } 53 \text { - Motor FEV. } & 100\end{array}$

$\begin{array}{lr}\text { Figura } 54 \text { - Visão dos termopares. } & 101\end{array}$

Figura 55 - Cabeçote do motor FEV.

Figura 56 - Sensores ópticos. 102

Figura 57 - Hardware do "Visio Scope". 102

Figura 58 - Captura de imagem. 102

Figura 59 - IndiModul. 103

Figura 60 - Tipos de transdutores utilizados. 103

Figura 61 - Sensor de posicionamento do PMS. 104

Figura 62 - Esquema de utilização do sensor de PMS. 105

Figura 63 - Análise aplicada a motor multicilíndrico. 106

$\begin{array}{ll}\text { Figura } 64 \text { - Diagrama P x V. } & 107\end{array}$

Figura 65 - Pressão no cilindro e taxa de queima. $\quad 108$

$\begin{array}{ll}\text { Figura } 66 \text { - Resposta em frequência. } & 108\end{array}$ 
Figura 67 - Bancada de fluxo (PIV) 109

Figura 68 - Esquema tridimensional dos gradientes de velocidades $\quad 110$

$\begin{array}{lr}\text { Figura } 69 \text { - Fluxo em uma secção transversal } & 110\end{array}$

Figura 70 - Fluxo em uma secção vertical 110

$\begin{array}{ll}\text { Figura } 71 \text { - Bancada de "spray”. } & 111\end{array}$

Figura 72 - Injeção de combustível. $\quad 112$

Figura 73 - Princípio de funcionamento. 112

$\begin{array}{ll}\text { Figura } 74 \text { - Medidor de Fluxo. } & 113\end{array}$

$\begin{array}{ll}\text { Figura } 75 \text { - Malha não estruturada. } & 114\end{array}$

$\begin{array}{ll}\text { Figura } 76 \text { - Fluxo frio } & 115\end{array}$

Figura 77 - Taxa de "Tumble". 116

$\begin{array}{lr}\text { Figura } 78 \text { - Perfil de escoamento. } & 117\end{array}$

$\begin{array}{ll}\text { Figura } 79 \text { - Evolução da temperatura. } & 118\end{array}$

$\begin{array}{ll}\text { Figura } 80 \text { - Evolução da frente de chama. } & 119\end{array}$

$\begin{array}{lr}\text { Figura } 81 \text { - Formação de produtos. } & 120\end{array}$

$\begin{array}{ll}\text { Figura } 82 \text { - Liberação de calor (acumulado). } & 121\end{array}$

$\begin{array}{lr}\text { Figura } 83 \text { - Curva de pressão no cilindro. } & 122\end{array}$

$\begin{array}{ll}\text { Figura } 84 \text { - Malhas computacionais } & 123\end{array}$

Figura 85 - Propriedade de simetria (ângulo de 60) 123

Figura 86 - Perfil de velocidade tangencial. $\quad 126$

$\begin{array}{ll}\text { Figura } 87 \text { - Perfil de velocidade radial. } & 126\end{array}$

$\begin{array}{ll}\text { Figura } 88 \text { - Perfil de temperatura total. } & 127\end{array}$

$\begin{array}{lr}\text { Figura } 89 \text { - Perfil de energia cinética turbulenta. } & 128\end{array}$

$\begin{array}{ll}\text { Figura } 90 \text { - Perfil de temperatura estática. } & 129\end{array}$

Figura 91 - Simulação x Experimental 130

$\begin{array}{ll}\text { Figura } 92-\text { Geometrias propostas. } & 131\end{array}$

Figura 93 - Energia cinética turbulenta. 132

Figura 94 - Comparativo Biflow e Beseline (TKE). 133

Figura 95 - Comparativo Screw e Baseline (TKE). 133

Figura 96 - Novas propostas de câmaras de combustão. 134

Figura 97 - Energia Cinética Turbulenta. 135

Figura 98 - Comparativo chapéu mexicano e baseline. 135

Figura 99 - Projetos mais promissores 136

$\begin{array}{ll}\text { Figura } 100 \text { - Massa de ar no cilindro. } & 137\end{array}$

$\begin{array}{lr}\text { Figura } 101 \text { - Pressão no cilindro. } & 138\end{array}$

Figura 102 - Comparativo entre dados simulados e experimentais. 139

Figura 103 - Comparativo entre dados simulados - calor acumulado. 139

Figura 104 - Frente de chama e taxa de queima a $8^{\circ}$ APMS ("Baseline”). 140

Figura 105 - Frente de chama e taxa de queima a $8^{\circ}$ APMS (“Biflow”). 141 
Figura 106 - Frente de chama e taxa de queima a $8^{\circ}$ APMS ("Mexhat'). 141

Figura 107 - Frente de chama e taxa de queima a 2 APMS ("Baseline”). 142

Figura 108 - Frente de chama e taxa de queima a 2 APMS ("Biflow”). 142

Figura 109 - Frente de chama e taxa de queima a 2 APMS ("Mexhat"). 143

Figura 110 - Frente de chama e taxa de queima a $8^{\circ}$ DPMS ("Baseline"). 143

Figura 111 - Frente de chama e taxa de queima a $8^{\circ}$ DPMS (“Biflow”). 144

Figura 112 - Frente de chama e taxa de queima a $8^{\circ}$ DPMS ("Maxhat"). 144

Figura 113 - Frente de chama e taxa de queima a 12 DPMS ("Baseline”). 145

Figura 114 - Frente de chama e taxa de queima a $12^{\circ}$ DPMS ("Biflow”). 145

Figura 115 - Frente de chama e taxa de queima a 12 DPMS ("Mexhat"). 146

Figura 116 - Frente de chama a $8^{\circ}$ DPMS (“Baseline”). 146

Figura 117 - Frente de chama a $8^{\circ}$ DPMS (“Biflow”). 147

Figura 118 - Frente de chama a 8 DPMS (“Mexhat”). 147

Figura 119 - Frente de chama e energia cinética turbulenta a $8^{\circ}$ APMS (“Baseline”). 148

Figura 120 - Frente de chama e energia cinética turbulenta a 8 APMS ("Biflow”). 148

Figura 121 - Frente de chama e energia cinética turbulenta a 8 APMS (“Mexhat”). 149

$\begin{array}{ll}\text { Figura } 122 \text { - Ângulo efetivo de queima. } & 151\end{array}$

Figura 123 - Ângulo efetivo de queima. $\quad 151$

Figura 124 - Rendimento indicado. 152

Figura 125 - Rendimento indicado. 153

Figura 126 - Câmara de combustão e pórticos de admissão. 154

Figura 127 - Injeção de combustível.

Figura 128 - Distorção do jato de combustível. 156

Figura 129 - Distorção do jato de combustível. 157

Figura 130 - Fechamento da válvula de admissão. 158

Figura 131 - Momento de ignição (25ํ APMS). 159

Figura 132 - Evaporação das gotas. 160

Figura 133 - Distribuição de $\Phi$ na câmara de combustão. $\quad 161$

Figura 134 - Efeito da inclinação do injetor (durante cruzamento de válvulas). 162

Figura 135 - Efeito da inclinação do injetor (término da admissão). 163

Figura 136 - Efeito da inclinação do injetor (momento da ignição). 164

Figura 137 - Efeito do ângulo do cone de injeção (371 graus). 165

Figura 138 - Efeito do ângulo do cone de injeção (579 graus). 166

Figura 139 - Efeito do ângulo do cone de injeção (695 graus). 166

Figura 140 - Efeito do ângulo do cone de injeção com inclinação (361 graus). 167

Figura 141 - Efeito do ângulo do cone de injeção com inclinação (579 graus). 167

Figura 142 - Efeito do ângulo do cone de injeção com inclinação (695 graus). 168

Figura 143 - Sequência 371, 579 e 695

Figura 144 - Comparação entre simulação e experimentação. 169 
Figura 145 - Comparação entre simulação e experimentação. 170

$\begin{array}{lr}\text { Figura } 146 \text { - Refluxo de combustível para o pleno (experimental). } & 170\end{array}$

$\begin{array}{lr}\text { Figura } 147 \text { - Formação de filme líquido. } & 171\end{array}$

Figura 148 - Comparativo de quantidade de filme líquido. 172

Figura 149 - Comparativo de quantidade de filme líquido. 172 


\section{GLOSSÁRIO}

A / C - Relação entre as massas de ar e combustível

APMS - Antes do Ponto Morto Superior

BSFC - Break Specific Fuel Consumption (Consumo Específico de Combustível)

CONAMA - Conselho Nacional de meio Ambiente

DPMS - Depois do Ponto Morto Superior

ICE - Ignição por Centelha Elétrica

FRC - Fluxo Radial de Compressão (squish)

FRE - Fluxo Radial de Expansão (reverse squish)

FRH - Fluxo Rotacional Horizontal (swirl)

FRV - Fluxo Rotacional Vertical (tumble)

FRVR - Fluxo Rotacional Vertical Reverso (reverse tumble)

GDI - Gasoline Direct Injection (Injeção Direta de Gasolina)

imep - Indicated Mean Effetive Pressure (Pressão Média Efetiva Indicada)

MBT - Mean Best Torque (Média do melhor torque)

mep - Mean Effetive Pressure (Pressão Média Efetiva)

MPFI - Multiport Fuel Injection (Injeção de combustível multiponto)

PFI - Port Fuel Injection (Injeção de combustível atrás da válvula de admissão)

PMI - Ponto Morto Inferior

PMS - Ponto Morto Superior

PROCONVE - Programa de Controle da Poluição do Ar por Veículos Automotores 
$\begin{array}{ll}\text { RPM } & - \text { Rotações Por Minuto } \\ \text { WOT } & - \text { Wide Open Throttle (Borboleta de Aceleração Totalmente Aberta) }\end{array}$ 


\section{Resumo}

SOUZA, S.G. (2014). "DESENVOLVIMENTO DE UMA CÂMARA DE COMBUSTÃO DE UM MOTOR DIESEL OTTORIZADO AUXILIADO POR SIMULAÇÃO 1D / 3D". São Carlos. Tese de Doutorado - Escola de Engenharia de São Carlos - USP.

Este trabalho apresenta uma análise comparativa entre diferentes geometrias de câmaras de combustão, no intuito de eleger a que proporcione queima mais adequada de etanol a um motor originalmente projetado para operar no ciclo Diesel que foi transformado para operar no ciclo Otto. O processo de formação de mistura é analisado desde a injeção de combustível no pórtico de admissão até o momento da ignição na câmara de combustão. Esta análise se baseia em simulações 1D e 3D, cujos modelos foram previamente validados em bancada experimental.

Palavras chave: motor, simulação, CFD, câmara de combustão, etanol, combustível alternativo. 


\begin{abstract}
SOUZA, S.G. (2014). “A COMBUSTION CHAMBER DEVELOPMENT AIDED FOR 1D / 3D SIMULATION FOR A DIESEL ENGINE CONVERTED TO OTTO CYCLE”.

This work presents a comparative analysis between different combustion chambers, in order to elect one to provide a more suitable burning ethanol in engine originally designed to operate on diesel cycle which has been converted to operate on Otto cycle. The mixture formation process is analyzed since the port fuel injection until ignition timing in combustion chamber. This analysis is based on 1D and 3D simulations, of which models were previously validated in experimental bench.
\end{abstract}

Keywords: engine, simulation, CFD, combustion chamber, ethanol. 


\section{INTRODUÇÃO}

Um motor Diesel Ottorizado é, em sua essência, um motor originalmente desenvolvido para operar no ciclo Diesel transformado para operar no ciclo Otto. Normalmente, seu cabeçote é plano e a câmara de combustão é determinada pela geometria do pistão, e no lugar do injetor de combustível se instala a vela de ignição. A razão de compressão é ajustada alterando-se o volume interno da câmara no pistão, e por consequência, sua forma.

Faz-se necessária uma avaliação do impacto da geometria dessa nova câmara de combustão desse novo "hardware motor" na eficiência da combustão.

Este trabalho tem por objetivo apresentar uma análise comparativa entre diferentes geometrias de câmaras de combustão no intuito de eleger a que proporcione queima mais adequada de etanol a um motor originalmente projetado para operar no ciclo Diesel que foi transformado para operar no ciclo Otto. Propõem-se análises qualitativas, por meio de ferramentas computacionais 1D / 3D, dos processos de formação de mistura e combustão. Embora muitos recursos experimentais tenham sido utilizados neste trabalho de pesquisa, futuros projetos de desenvolvimento dessa área podem ter seus tempos e custos reduzidos, uma vez que os modelos de tais ferramentas computacionais foram validados.

A conversão em questão também foi realizada, tornando viável o uso do etanol hidratado como fonte renovável de energia alternativa aos combustíveis fósseis. 


\section{MOTORES DE COMBUSTÃO INTERNA DO CICLO}

\section{OTTO}

Segundo Obert (1971), os motores de combustão interna com ignição por centelha (ICE), ou ciclo Otto, tiveram início em 1862, quando o físico francês Beau de Rochas propôs uma sequência de operações que futuramente, se tornaria típica dos motores de ignição por centelha.

Essa sequência determina o ciclo de trabalho, sendo descrita da seguinte forma:

Admissão: uma mistura ar-combustível é aspirada para o interior do cilindro, com a válvula de admissão aberta e a de descarga fechada, quando o pistão desloca-se do ponto morto superior (PMS) ao ponto morto inferior (PMI), gerando uma região de baixa pressão no interior do cilindro, permitindo assim, que a pressão atmosférica empurre a mistura para o interior do cilindro.

Compressão: com as duas válvulas fechadas, inicia-se a subida do pistão, comprimindo a mistura ar-combustível;

Expansão: nas proximidades do ponto morto superior, gera-se uma centelha que será responsável pelo início da queima do combustível, e na medida em que a frente de chama se propaga no interior da câmara de combustão, há, consequentemente, grandes aumentos de pressão e temperatura no interior do cilindro. Quando o pistão passa pelo PMS, a pressão se aproxima de seu valor máximo, fazendo com que o pistão seja fortemente empurrado para baixo, realizando trabalho. 
Exaustão: com a válvula de exaustão aberta e a de admissão fechada, inicia-se a subida do pistão, promovendo a expulsão dos gases queimados para o sistema de escapamento. A partir daí todo o processo se repete.

Apesar de Beau de Rochas ter formulado as condições de funcionamento desse motor, foi Nikolaus Otto, em 1876, quem construiu o primeiro motor ICE de quatro tempos (OBERT. 1971).

A abertura e o fechamento das válvulas de admissão e exaustão ocorrem em momentos específicos definidos pelo projeto do motor, em função da maior eficiência volumétrica, e do perfil da curva de torque desejada. Na Figura 01 observa-se um diagrama típico dos motores modernos, para os processos de abertura e fechamento das válvulas.

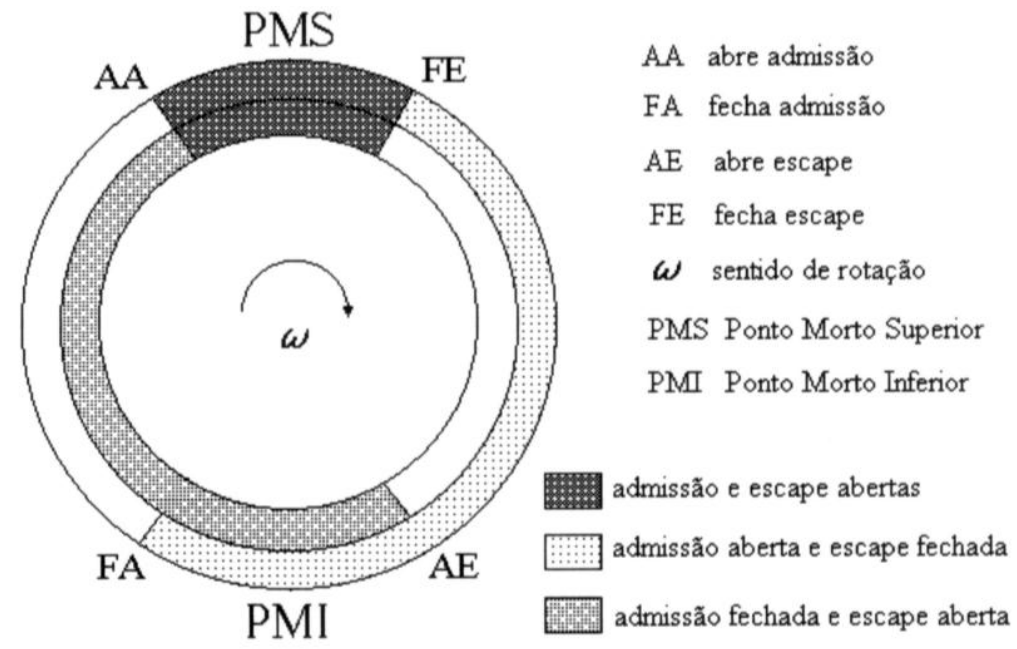

Figura 01 - Diagrama de válvulas. (SANTOS, 2000)

Os motores de combustão interna têm sido instrumento de pesquisa há mais de um século, período em que sofreram diversas modificações tecnológicas.

$\mathrm{Na}$ busca de motores de maior desempenho e baixo consumo específico que sejam capazes de atender às normas de emissões de poluentes, a eletrônica embarcada têm sido uma 
das maiores aliadas ao processo de integração e automação dos diversos dispositivos dos motores modernos.

O processo de formação da mistura ar-combustível sempre é alvo de muita investigação, pois é necessário que se tenha um completo controle sobre as diversas variáveis que regem tal fenômeno para as mais diversas condições de funcionamento do motor, seja em regime estacionário ou transitório. Esse conhecimento possibilita modelagens mais realísticas capazes de representar matematicamente os fenômenos físico-químicos envolvidos nesse processo.

Idealmente, o fornecimento de mistura aos cilindros do motor deveria se dar com a mínima perda de eficiência volumétrica, por exemplo, o diâmetro e o comprimento do coletor de admissão deveriam variar continuamente em função da rotação. É claro que tal situação parece ser pouco provável de se encontrar na prática. O que normalmente se encontram são coletores cujos comprimentos variam de forma discreta em diferentes regimes de rotações.

Também é notável a evolução do sistema de ignição, onde os tradicionais dispositivos mecânicos, de funcionalidades limitadas, deram lugar a dispositivos de controle eletrônicos, muitas vezes integrados ao sistema de injeção eletrônica, capazes de gerenciar o momento ideal para o disparo da centelha com maior grau de confiabilidade a partir de um mapeamento (tabela de pontos), com dados levantados numa bancada dinamométrica.

No processo de evolução dos motores de ignição por centelha, as câmaras de combustão do início do século 20 possuíam formas que as faziam ser identificadas por letras, como por exemplo, cabeçote tipo “T”, utilizado pela Mercedes - Benz em 1901, com o sistema de admissão de um lado do cilindro e o sistema de escapamento do outro, com as respectivas faces voltadas para cima; cabeçote tipo "L", uma versão mais simples dos cabeçotes tipo “T”, utilizada a partir de 1910, onde as válvulas de admissão e escape encontram-se do mesmo lado do cilindro, mas ambas com as faces para cima; cabeçote tipo "I", utilizado pela Buick, 
assemelhando-se às atuais câmaras em forma de cunha; e os cabeçotes tipo "F" (RINSCHLER e ASMUS, 1995). Alguns exemplos dessas câmaras são mostrados na Figura 02:

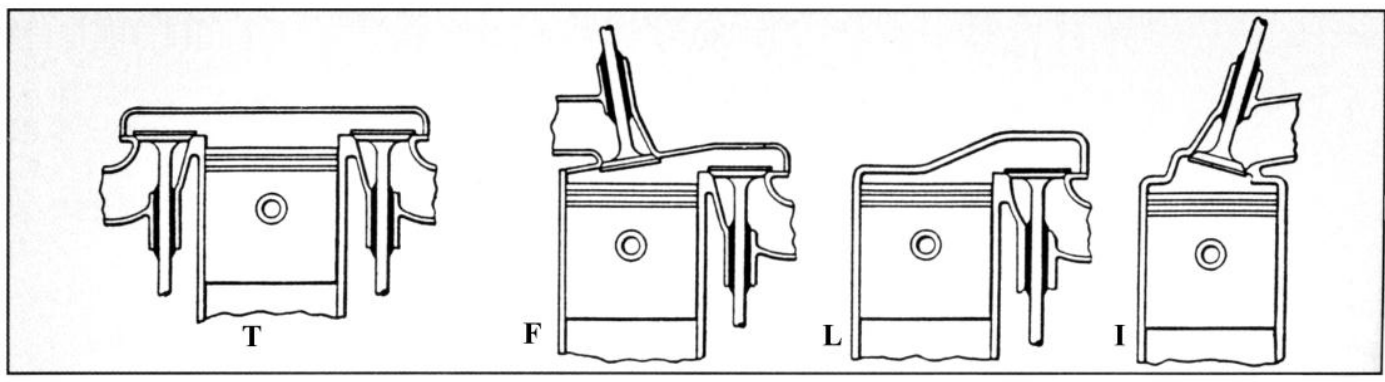

Figura 02 - Cabeçotes em T, F, L, I. (RINSCHLER e ASMUS, 1995).

Ao longo deste trabalho serão mostrados mais detalhes de tais câmaras.

Naturalmente, outro aspecto fundamental para o funcionamento dos motores é o combustível que utilizam. Os combustíveis derivados do petróleo têm sido os de mais ampla utilização, mas, nas últimas décadas, os combustíveis renováveis, principalmente o etanol, têm ganhado importância, inicialmente em razão da escassez e / ou custo do petróleo e, mais recentemente, em razão de regulamentação de emissões poluentes.

O Brasil tem mostrado ao mundo sua experiência na aplicação do etanol hidratado como combustível alternativo. 


\section{PROCESSO DE FORMAÇÃO DA MISTURA AR- COMBUSTÍVEL}

Em função do regime de funcionamento, um motor ICE pode operar com uma grande variação da relação ar / combustível, sendo essa relação definida como a razão entre as massas de ar e de combustível na mistura (A/C). A razão entre A/C real admitida pelo motor e A/C estequiométrica (mistura quimicamente correta) é definida como fator de excesso de ar $(\lambda)$ :

$$
\lambda=\frac{(A / C) \operatorname{Re} a l}{(A / C) \text { Estequiometrica }}
$$

Sendo:

$\lambda=1$ indica uma mistura estequiométrica;

$\lambda>1$ indica uma mistura pobre (excesso de ar, ou seja, com menos combustível que a estequiométrica);

$\lambda<1$ indica uma mistura rica (falta de ar, ou seja, com mais combustível que a estequiométrica).

Os valores ilustrados abaixo representam uma ideia aproximada da faixa de operação prática dos valores de $\lambda$ :

$0,75<\lambda<0,85$ - máxima potência;

$0,85<\lambda<0,90$ - transição rápida entre regimes;

$1,0<\lambda<1,4-$ economia de combustível; 
$0,95<\lambda<1,05$ - funcionamento ideal do catalisador de 3 vias;

Alguns motores atuais podem operar com $\lambda$ em torno de 1,7 em determinados regimes, visando máxima economia de combustível e menores índices de emissões de poluentes.

\subsection{VOLATILIDADE}

A volatilidade é um fator importante no processo de formação de mistura, sendo definida como a tendência de um líquido de evaporar. Segundo Taylor (1976), nos motores que queimam uma mistura uniforme de vapor de combustível e ar, a razão vapor / ar não deve ser inferior a cerca de metade da estequiométrica para ignição satisfatória à propagação da chama. Dessa forma a volatilidade do combustível deve ser suficiente para fornecer pelo menos essa razão vapor / ar no instante da ignição em todas as condições de operação, incluindo a partida e aquecimento de um motor frio.

A razão da massa de vapor de combustível para a massa de ar, em dado instante, pode ser expressa pela equação (2):

$$
F_{v}=\frac{m_{f v} p_{f}}{M_{a r}\left(p-p_{f}\right)}
$$

Sendo $F_{v}$ a razão da massa de combustível evaporado em relação à massa de ar; $m_{f v}$ o peso molecular médio do vapor de combustível; $p_{f}$ a pressão parcial do vapor de combustível; $M_{a r}$ a massa molecular do ar; e $p$ a pressão total da mistura.

Se o combustível é uma mistura de vários constituintes, para qualquer constituinte no equilíbrio com combustível líquido, temos:

$$
p_{f}=p_{v}\left(\frac{M}{M_{L}} \frac{m_{L}}{m}\right)
$$


Sendo $p_{v}$ a pressão normal de vapor do constituinte em questão; $M$ a massa do constituinte no líquido; $M_{L}$ a massa do líquido remanescente; $m$ o peso molecular do constituinte; $m_{L}$ o peso molecular médio do líquido remanescente.

Embora a volatilidade a baixas temperaturas seja desejável para a partida, o bloqueio de vapor ("vapour lock"), devido a uma rápida formação de vapor no sistema de fornecimento de combustível é claramente indesejável na temperatura normal de funcionamento.

Outro fator indesejável é a perda por evaporação no tanque de combustível por combustíveis de alta volatilidade, provocando problemas em relação a poluição do ar. Em contrapartida, baixa volatilidade do combustível pode provocar diluição do óleo lubrificante pelo combustível não evaporado, reduzindo a viscosidade do mesmo.

\subsection{TIPO DE MISTURA}

Os motores do ciclo Otto podem ser classificados como: motores de mistura homogênea (distribuição uniforme da mistura ar-combustível na câmara de combustão) e motores de carga estratificada (distribuição não uniforme da mistura ar-combustível na câmara de combustão).

\subsubsection{Motor de Mistura Homogênea}

Os motores de mistura homogênea devem preparar e queimar uma mistura devidamente homogeneizada, devendo diminuir, ao máximo, as variações inevitáveis desse grau de homogeneidade. Esses motores podem trabalhar com mistura estequiométrica ou pobre, dependendo de seu projeto. No caso de se buscarem menores índices de emissões e de consumo de combustível, a estratégia de empobrecimento da mistura homogênea deve ser feita de maneira criteriosa, pois o empobrecimento da mistura na região da vela de ignição aumenta a probabilidade de falhas do motor. Por isso, os primeiros motores de queima pobre utilizavam câmara auxiliar. 
Automotive Engineering (1974) apresentou uma matéria sobre o motor Honda CVCC (compound vortex controled-combustion) que utilizava câmara auxiliar, (normalmente com aumento de 4 a $12 \%$ do volume do cilindro) onde a mistura pobre era introduzida no cilindro através do sistema de alimentação convencional, enquanto que uma mistura rica era formada na câmara auxiliar, na qual se localizava a vela de ignição. Embora seja aparente uma estratificação de carga, muitas vezes a mesma tem o intuito apenas de garantir a queima da mistura homogênea excessivamente pobre na câmara principal.

\subsubsection{Motor de Carga Estratificada}

A estratificação pode ser feita com ou sem o auxílio de câmara auxiliar, caracterizando-se pela admissão de ar fresco para o interior do cilindro, e ao final da fase de compressão por uma concentração de mistura rica em torno da vela, seja por meio de injeção direta na câmara de combustão ou pela injeção na câmara auxiliar. No caso do motor Honda CVCC, a estratificação será realmente consolidada quando possivelmente não houver admissão de mistura pelo sistema principal (AUTOMOTIVE ENGINEERING, 1974).

\subsubsection{Efeito das Condições Operacionais Sobre o Requisito de Mistura}

Os requisitos de mistura para os motores de ignição por centelha podem mudar substancialmente em função das condições operacionais do motor, como: partida a frio, aquecimento, marcha lenta, carga parcial, plena carga e acelerações, conforme mostrado a seguir:

\subsubsection{Partida a frio}

Durante a partida a frio, a baixa taxa de evaporação do combustível torna a mistura na câmara de combustão muito pobre, devido à remoção de uma fração do combustível gasoso pelo contato com as superfícies ainda frias do motor. Para compensar esse empobrecimento e 
facilitar a partida, promove-se um débito suplementar de combustível, variável conforme estratégia do fabricante.

\subsubsection{Fase de aquecimento}

Após a partida a frio, o motor ainda precisa de um enriquecimento da mistura até que o coletor de admissão, o cabeçote e a parede dos cilindros atinjam uma temperatura capaz de alcançar uma máxima eficiência no processo evaporativo do combustível.

\subsubsection{Marcha Lenta}

Nessa condição, o motor está operando com a borboleta fechada, sem carga aplicada ao motor. Todo o torque produzido pelo motor é suficiente apenas para manter o motor operante.

Devido ao cruzamento das válvulas de admissão e descarga e como a pressão no interior do cilindro ao final do curso de descarga é maior que a pressão no coletor de admissão, parte dos gases resultantes da combustão penetra no coletor de admissão, diluindo a mistura fresca, e diminuindo a taxa de queima da mesma. Para compensar, faz-se um enriquecimento da mistura.

\subsubsection{Cargas Parciais}

Regime compreendido desde a abertura da borboleta até aproximadamente $3 / 4$ da abertura total. Normalmente, os motores convencionais trabalham com mistura estequiométrica nesse regime, mas alguns motores a gasolina de queima pobre estão aptos a trabalhar com relação ar-combustível entre 18:1 e 25:1.

\subsubsection{Plena Carga}

Regime de carga obtida com a borboleta quase que totalmente aberta (mais de $3 / 4$ de sua abertura total). $\mathrm{O}$ enriquecimento da mistura é fundamental nesse regime devido ao requisito de potência. 


\subsubsection{Acelerações}

O potencial de evaporação é fortemente afetado pelo nível de pressão no coletor de admissão. $\mathrm{O}$ aumento repentino na pressão do coletor provocado pela abertura rápida da borboleta de aceleração provoca baixos níveis de evaporação de combustível nas paredes do coletor, do cabeçote e do cilindro, exigindo o enriquecimento da mistura.

\subsubsection{Desaceleração}

O processo de evaporação na desaceleração é o inverso do verificado na aceleração, uma vez que o nível de evaporação é aumentado com a queda repentina de pressão no coletor de admissão, tornando a mistura mais rica.

Como esse enriquecimento é desnecessário nessa condição, adota-se a estratégia dash-pot (desaceleração progressiva) e cut-off (bloqueio momentâneo no suprimento de mistura ou combustível) eliminando-se esse inconveniente, responsável por emitir altos índices de poluentes.

\subsection{DINÂMICA DA ADMISSÃO}

\subsubsection{Influência do Coletor de Admissão}

O coletor de admissão tem uma importância fundamental no processo de formação de mistura, e conseqüentemente, no desempenho do motor. A escolha do coletor deve ser feita de forma criteriosa em função dos requisitos de projeto do motor, ou seja, requisito de alto torque em baixas rotações, requisito de potência em altas rotações, etc., uma vez que tais requisitos podem ser conflitantes entre si. A eficiência volumétrica e a Mep (pressão média efetiva) são afetadas pela dinâmica do sistema de admissão. Em geral, um coletor de admissão deve atender a diversos requisitos, como por exemplo:

- Promover distribuição uniforme de mistura para todos os cilindros do motor; 
- Promover rápida descarga de mistura para os cilindros;

- Promover baixa perda de carga;

- Promover baixo acúmulo de filme de combustível não vaporizado;

Para isso, alguns critérios devem ser adotados:

\subsubsection{Comprimento do Coletor}

Segundo Heisler (1995), quando se fixa o diâmetro do coletor de admissão, observa-se que (Figura 03):

- Um coletor longo possui uma área de atrito maior que a de um coletor curto, provocando maior resistência ao fluxo de ar ou mistura;

- Uma maior área de atrito também corresponde a uma maior área para troca de calor;

- O valor de pico da eficiência volumétrica é alcançado a menores rotações quando se aumenta o comprimento do coletor;

- O valor de pico da eficiência volumétrica é maior no coletor longo do que o valor de pico para o coletor curto;

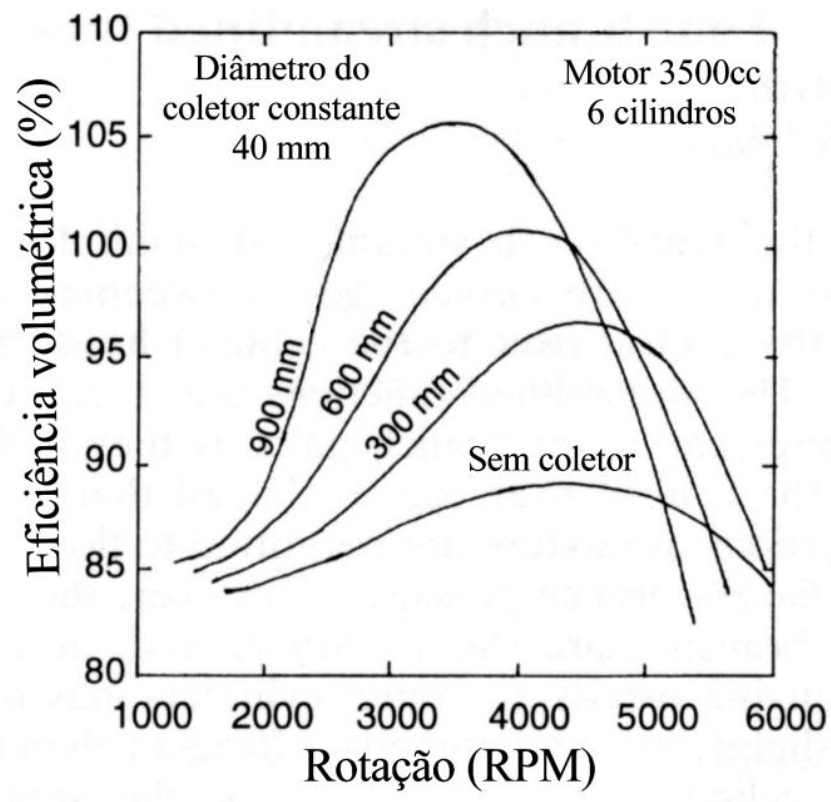

Figura 03 - Coletor de comprimento variável (HEISLER, 1995). 


\subsubsection{Diâmetro do Coletor}

Segundo Heisler (1995), quando se fixa o comprimento do coletor de admissão, observase que (Figura 04):

- Um coletor de maior diâmetro possui uma área de troca de calor maior que a de um coletor de menor diâmetro;

- Um coletor de menor diâmetro aumenta a velocidade de escoamento do fluido diminuindo a rotação em que ocorre o pico da eficiência volumétrica;

- O valor de pico da eficiência volumétrica praticamente não parece variar com o diâmetro do coletor, somente a rotação em que ocorre;

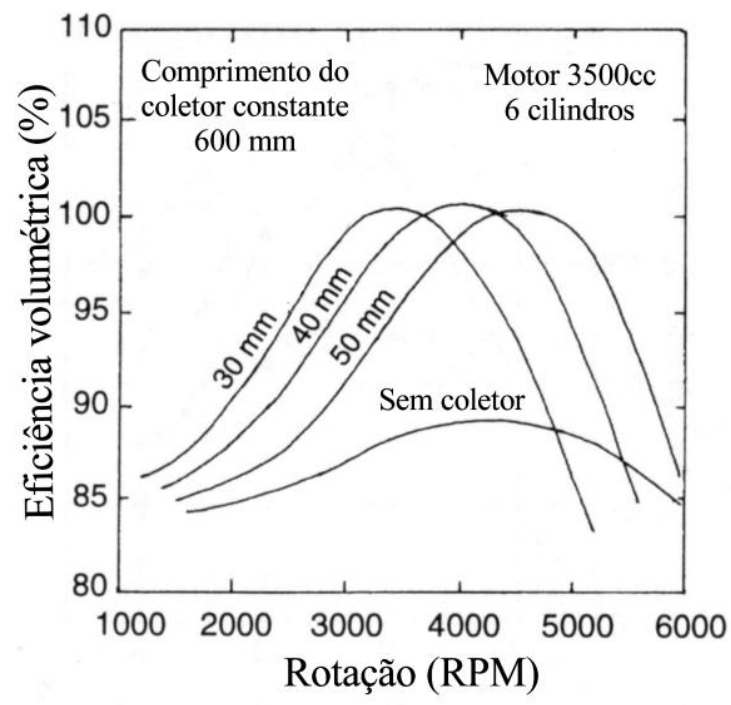

Figura 04 - Coletor de diâmetro variável (HEISLER, 1995).

Lenz (1992) mostrou um ensaio feito com um motor cujo coletor de admissão era de variação contínua do comprimento, o qual demontrou uma apreciável melhora na dinâmica da admissão, gerando maior desempenho do motor. A Figura 05 mostra a relação entre a pressão média efetiva (Mep) e a rotação do motor para esse tipo de coletor e para o mesmo motor com coletor comum. 


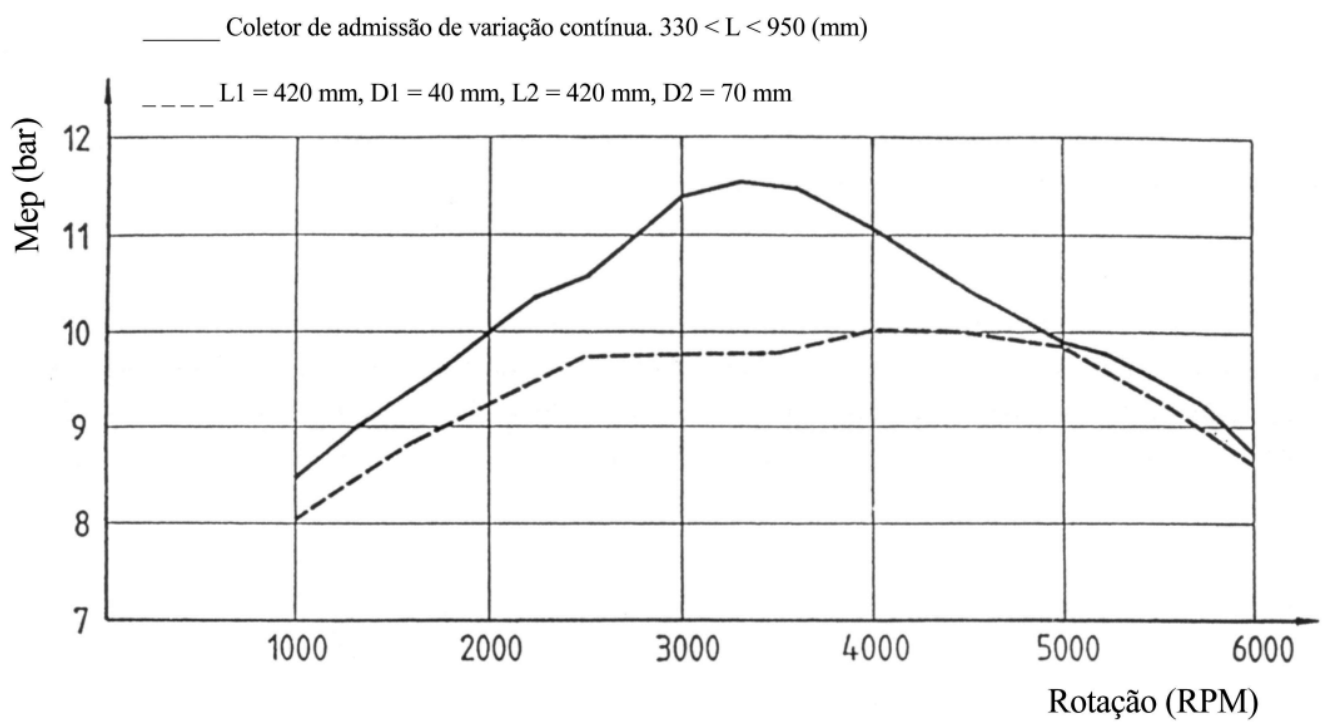

Figura 05 - Comparação entre um coletor de comprimento continuamente variável e um convencional (LENZ, 1992).

Analisando a Figura 05, pode-se perceber o melhor desempenho do sistema de coletor de variação contínua em todos os regimes de rotações ensaiados.

\subsubsection{Influência do Duto de Admissão do Cabeçote}

O projeto do cabeçote tem uma vital importância no processo de formação de mistura, onde a geometria e dimensões de seus componentes são responsáveis pela garantia de que a mistura estará nas condições ideais de queima prevista pelo projeto do motor. Fatores como dimensões e geometria do duto de admissão, válvula(s) de admissão, câmara de combustão, diagrama de válvulas, etc., devem ser cuidadosamente analisados.

Diversas formas de duto de admissão foram desenvolvidas para garantir os níveis de turbulência desejados:

\subsubsection{Geração de Fluxo Rotacional Horizontal (FRH)}

FRH é o fluxo rotacional da carga no interior do cilindro em torno de seu eixo, produzido pelo posicionamento do duto de entrada para um lado do eixo do cilindro, a fim de induzir um fluxo de carga tangencial à parede do cilindro, ou mesmo pela adição de elementos direcionadores de fluxo capazes de gerar o mesmo efeito (Figura 6). 
Para fins quantitativos, define-se a taxa de FRH como a velocidade rotacional da carga (velocidade angular) dividida pela velocidade rotacional do virabrequim. O FRH também é conhecido como "swirl", utilizado sem tradução em algumas literaturas.

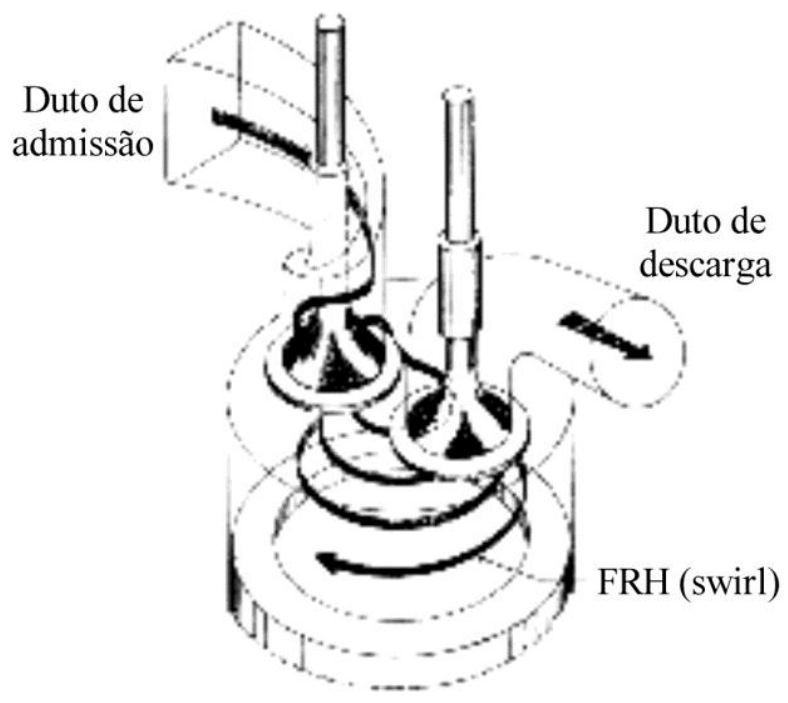

Figura 6 - Duto de admissão helicoidal para geração de FRH (swirl) (HEISLER, 1995).

\subsubsection{Geração de Fluxo Rotacional Vertical (FRV)}

FRV é o fluxo rotacional da carga no interior do cilindro em torno de um eixo horizontal em forma de loop, que normalmente se estende até o final da fase de compressão, produzido pelo posicionamento do duto de admissão e pela inclinação da (s) válvula (s) de admissão. O FRV é geralmente característico de câmaras em forma de telhado (pentroof). O FRV também é conhecido como "tumble", como pode ser observado na Figura 7. 


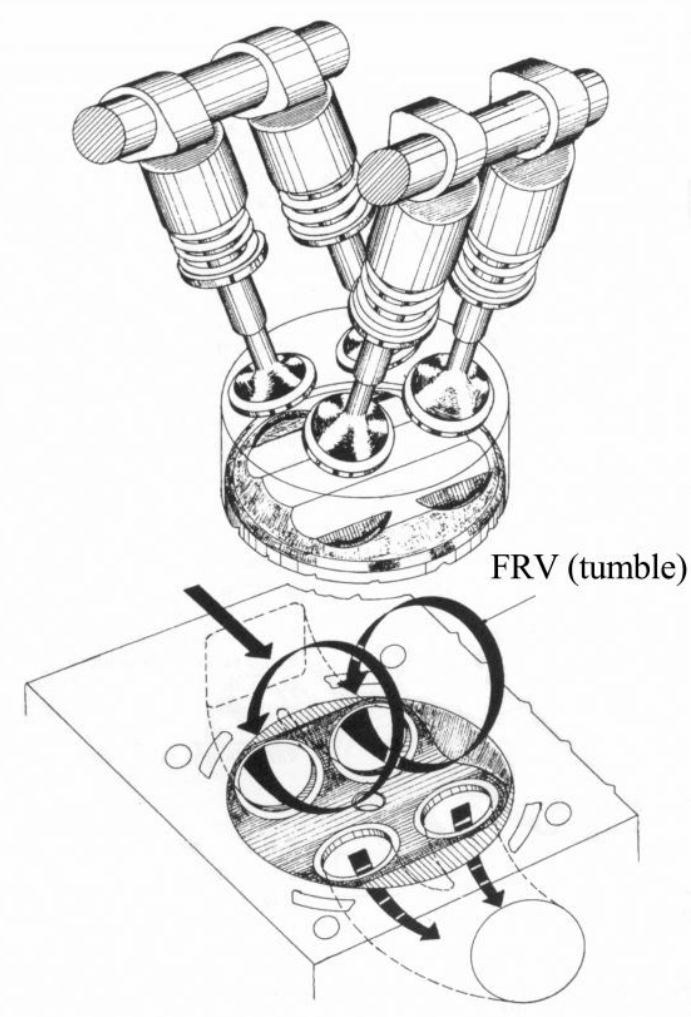

Figura 7 - Fluxo Rotacional Vertical (HEISLER, 1995).

\subsubsection{Duto de Admissão de Fluxo Direto}

$\mathrm{O}$ ar ou a mistura fresca é induzido a passar por um duto geralmente de paredes paralelas (Figura 08), provocando um fluxo direto através da válvula de admissão devidamente posicionada para garantir a geração de FRH no interior do cilindro. Quando a câmara possui duas ou mais válvulas de admissão, esse tipo de duto é geralmente utilizado para a geração de FRV. 


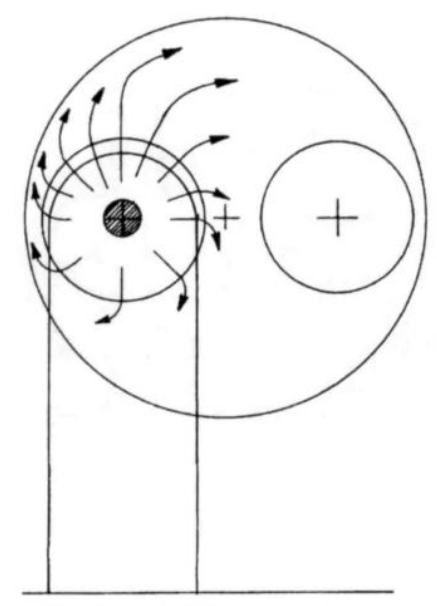

Figura 08 - Duto de admissão de fluxo direto (HEISLER, 1995).

\subsubsection{Duto de Admissão de Parede Semicircular}

$\mathrm{O}$ ar ou a mistura fresca é forçado a fluir por um duto de entrada de parede levemente encurvada (Figura 9) a fim de promover um fluxo semicircular até a válvula, por onde passa, provocando um movimento em forma de espiral descendente no interior do cilindro.

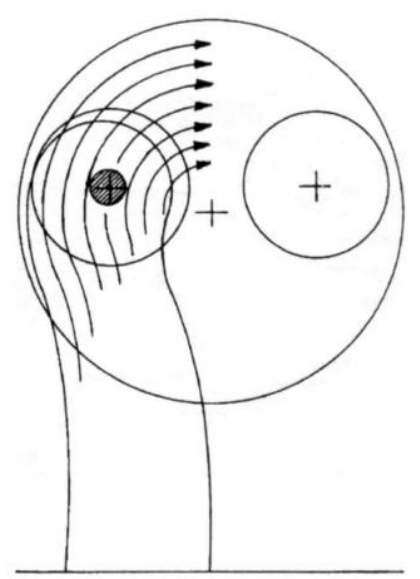

Figura 9 - Duto de admissão de parede semicircular (HEISLER, 1995). 


\subsubsection{Duto de Admissão com Válvula Restrita}

$\mathrm{O}$ ar ou a mistura fresca é normalmente forçado a fluir por um duto de fluxo direto, onde o direcionamento do fluxo é feito por uma máscara de restrição na válvula de admissão (Figura 10).

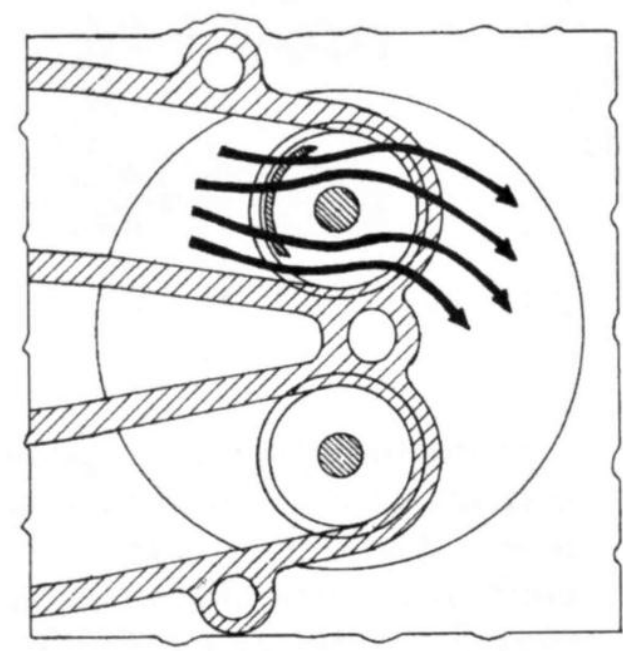

Figura 10 - Duto de admissão com válvula restrita (HEISLER, 1995).

\subsubsection{Duto de Admissão Helicoidal}

Nessa configuração, o FRH é gerado no interior do duto de admissão, acima da sede da válvula de admissão, sendo então, a mistura descarregada no interior do cilindro, normalmente utilizado em motores de queima pobre (Figura 6).

\subsubsection{Duto de Admissão com Paredes de Deflexão}

A mistura é forçada a fluir por um duto de inclinação acentuada, tendo uma parede que restringe o fluxo em uma extremidade da válvula de admissão, onde a descarga de mistura é feita em direção à vela de ignição.

Segundo Heisler (1995), uma característica muito importante desse tipo de duto é sua interação com a geometria da câmara de combustão, que produz o movimento de rotação mais 
significativo do que o movimento descendente, garantindo um intenso FRH durante o curso de admissão (Figura 11).

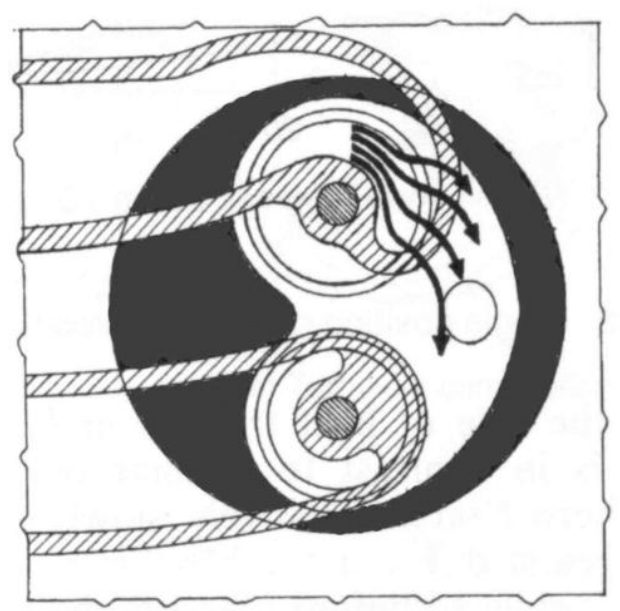

Figura 11 - Duto de admissão com paredes de deflexão (HEISLER, 1995).

\subsubsection{Influência da configuração da válvula de admissão}

Como já foi dito antes, a baixa eficiência volumétrica dos motores de combustão interna certamente é o fator mais importante no fornecimento de mistura aos cilindros. A eficiência volumétrica pode ser definida como a massa de mistura fresca que entra no cilindro, em um curso de aspiração, dividida pela massa de mistura que encheria o espaço correspondente ao deslocamento do pistão, para uma determinada densidade da mistura, expressa algebricamente por:

$$
e_{v}=\frac{2 M_{i}}{N V_{d} \rho_{i}}
$$

Sendo $e_{v}$, a eficiência volumétrica; $M_{i}$, a massa de mistura fresca por unidade de tempo; $N$, rotações por unidade de tempo; $V_{d}$, volume de deslocamento total do motor; $\rho_{i}$, a densidade da mistura de admissão.

Nos motores cujos cruzamentos de válvulas são variáveis, as diferentes combinações de cruzamentos das válvulas são otimizadas para se obter a máxima eficiência volumétrica para as diversas condições de funcionamento do motor. Seja de forma eletrônica ou mecânica, esse tipo de configuração permite que se trabalhe com um cruzamento de válvulas de zero grau 
para o regime de marcha lenta impedindo o refluxo de gases queimados para o coletor de admissão e permitindo o emprego de misturas mais pobres nessa condição, o que diminui também a variação de pressão no cilindro ciclo a ciclo (variação cíclica), como mostrado por Henry (2001). Na medida em que se aumenta a rotação do motor, aumenta-se o cruzamento de válvulas, melhorando-se a eficiência volumétrica do motor.

No caso do sistema de acionamento eletrônico das válvulas, pode-se ainda aumentar a permanência de abertura de cada válvula, algo que não se pode fazer com o sistema mecânico.

Mas até se chegar a essa tecnologia, muitas tentativas foram feitas no intuito de se melhorar a eficiência volumétrica dos motores de ignição por centelha sem o comprometimento dos níveis de turbulência exigidos para uma ótima homogeneização da mistura antes da queima.

Lee (1938) ensaiou diferentes tipos de escoamentos de ar de admissão por meio de válvulas restritas com máscara de restrição de $180^{\circ}$ sob diferentes posicionamentos, para um motor de injeção direta de combustível, como mostrado na Figura 12.

Observou-se que a velocidade de escoamento era o dobro da velocidade obtida com válvulas sem restrição. As taxas de FRH obtidas pelos arranjos B e E foram iguais e menores que as dos arranjos A e C. Altos índices de turbulência foram atingidos, provavelmente porque em cada caso uma válvula descarregava em direção à outra.

Nesse experimento, concluiu-se que:

- O movimento do ar criado no cilindro na fase de admissão continuava durante a fase de compressão, auxiliando na distribuição do jato de gasolina injetada no cilindro;

- A velocidade de indução de ar era aproximadamente proporcional à rotação do motor e inversamente proporcional à área de entrada da válvula de admissão;

- A máxima taxa de FRH era alcançada em torno de $110^{\circ}$ do eixo do virabrequim após o começo da fase de admissão, sendo esse movimento encontrado até o final da fase de exaustão; 
- Quando as válvulas eram postas a garantir um fluxo direto, como na configuração F, era gerado FRV, que se estendia até o final da fase de compressão.

É importante notar que nessas experiências eram mantidas rotações muito baixas, onde a eficiência volumétrica não era um problema. Possivelmente seus resultados não podem ser extrapolados para altas rotações, onde as perdas de cargas são consideráveis. Portanto, a utilização de válvulas restritas só seria interessante para baixas rotações, mas inviáveis para altas (LEE, 1938).

No caso dos motores com duas válvulas de admissão, a solução para o problema de perda de eficiência volumétrica parece ter sido feita pela utilização de borboleta de restrição em um dos dutos de entrada, de forma que essa possa ser aberta quando necessário.

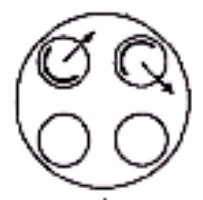

A

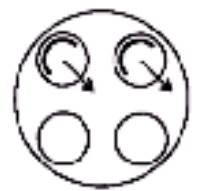

D

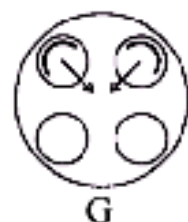

$\mathrm{G}$

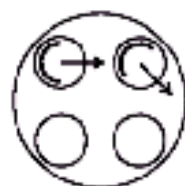

B

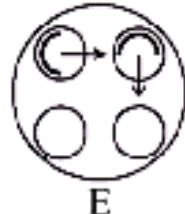

E

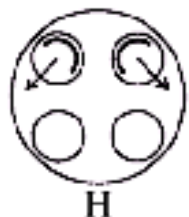

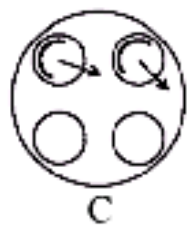
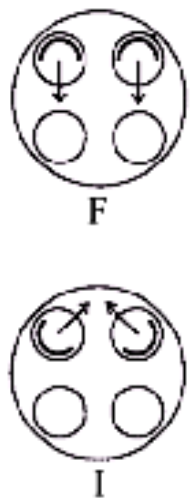

Figura 12 - Diferentes combinações de múltiplas válvulas de admissão restritas (LEE, 1938).

Urushihara et al. (1996) mostraram que as taxas de FRH e FRV são maiores na utilização de duplo duto de entrada com borboleta restritiva em um deles do que na utilização de válvulas restritas.

Automotive Engineer (1977) mostrou outra estratégia para se aumentar a indução de FRH, através da utilização de uma pequena válvula auxiliar (cerca de $10 \mathrm{~mm}$ para um 
diâmetro de $80 \mathrm{~mm}$ ) na câmara de combustão, que está ligada a um by-pass de menor diâmetro, aumentando a velocidade de escoamento a baixas rotações (Figura 13, p. 24).

Admissão e Compressão

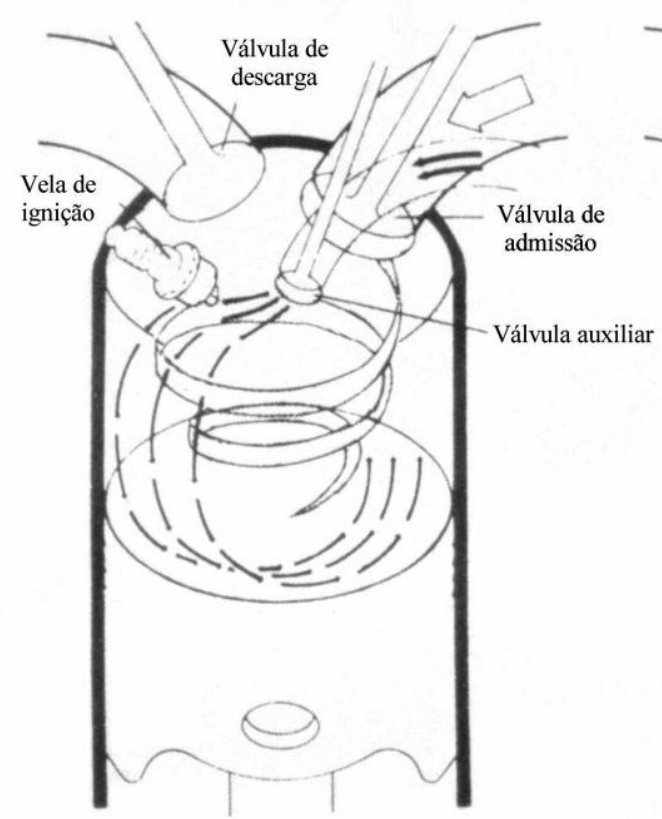

Compressão e Ignição

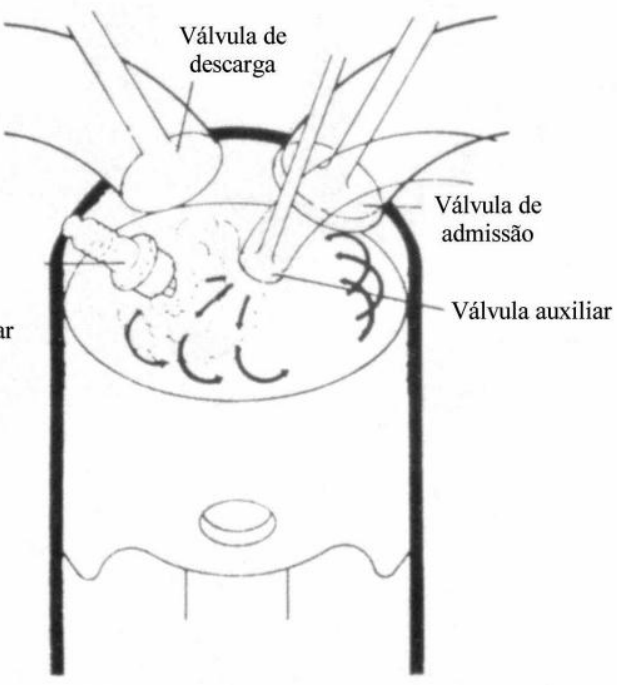

Figura 13 - Geração de FRH por meio de válvula auxiliar (AUTOMOTIVE ENGINEER, 1977).

Outra forma é utilizar dutos de admissão variáveis (Figura 14), onde duas ou mais válvulas de admissão têm o fluxo de ar ou de mistura ar-combustível controlados simultaneamente por uma borboleta de restrição, onde por meio de uma passagem auxiliar em apenas um dos dutos pelo qual o fluxo será estabelecido. Ou seja, em baixas rotações a borboleta de restrição encontra-se fechada, bloqueando o fluxo no duto principal, havendo apenas fluxo na passagem auxiliar, que se comunica com apenas uma das válvulas de admissão. Em rotações mais elevadas a borboleta de restrição encontra-se aberta, permitindo fluxo livre por todas as válvulas de admissão. 


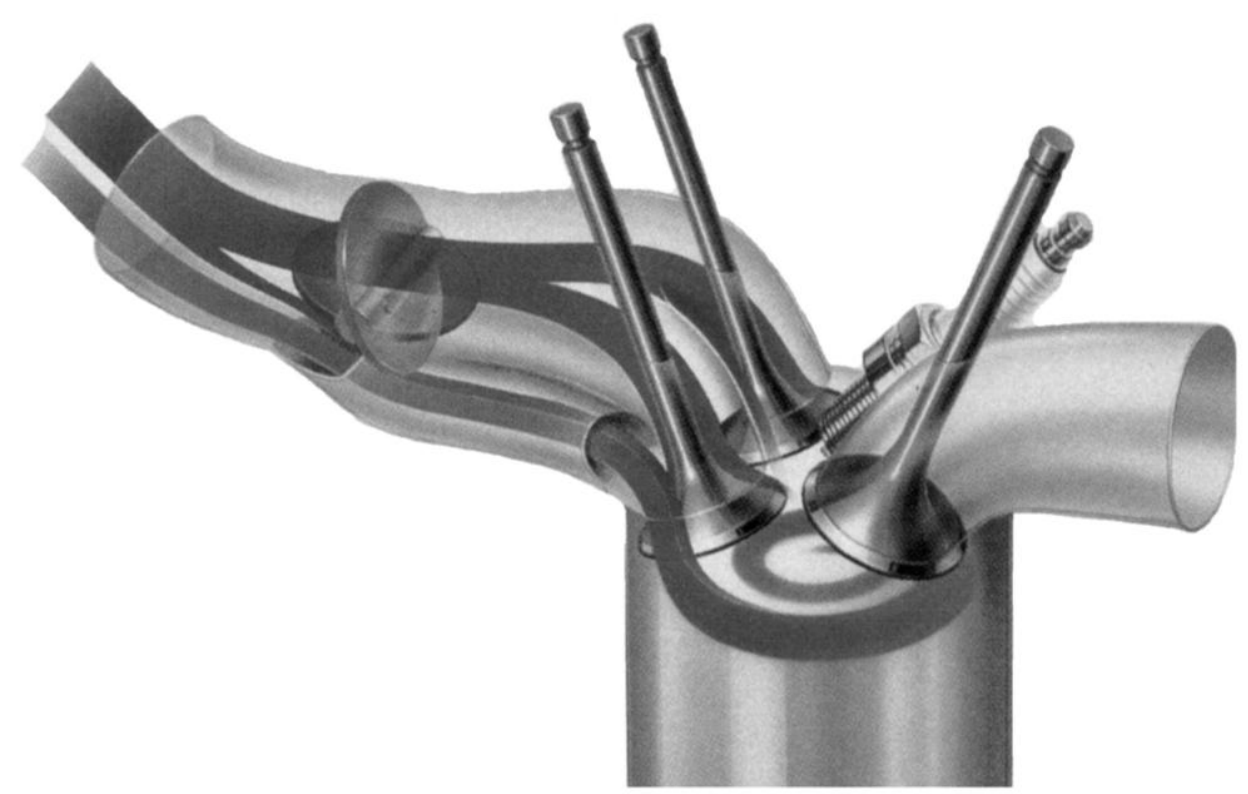

Figura 14 - Duto de admissão variável (AUTOMOTIVE ENGINEERING, 1987).

Outro aspecto importante da configuração das válvulas de admissão é a relação entre o momento de abertura das válvulas e o de injeção de combustível, no caso de injeção PFI (injeção no duto de admissão).

Brehm e Whitelow (1999) analisaram o comportamento do motor com injeção no duto de admissão com válvula de admissão aberta, e com válvula fechada, e concluíram que:

- Injeção de combustível com válvula fechada tem vantagens sobre injeção com válvula aberta, com o motor aquecido e em condições de mistura homogênea;

- Injeção de combustível com válvula aberta tem vantagens sobre injeção com válvula fechada na fase de aquecimento, quando a evaporação do combustível ainda é deficiente promovendo acúmulo de combustível líquido na válvula de admissão, e nas condições transitórias, assim como em plena carga. 


\section{FORMAÇÃO DA MISTURA AR-COMBUSTÍVEL NA CÂMARA DE COMBUSTÃO}

Algumas características dos motores tais como: torque, potência, consumo de combustível, etc., são profundamente afetadas pela taxa de compressão, forma da câmara de combustão, número e tamanho das válvulas de admissão e descarga e posição da vela de ignição. Dessa forma, não se pode falar de câmara de combustão sem falar de todos esses fatores. Um exemplo importante dessa interação é o "duto de admissão com paredes de deflexão", visto na sessão 3.3.2.7, que mostra uma forte relação entre o projeto do duto de admissão e da câmara de combustão.

Os motores à gasolina com injeção direta de combustível (GDI) possuem câmaras de combustão projetadas para que o processo de formação de mistura se dê exclusivamente em seu interior (ver sessão 6.2, p. 63), mas mesmo nos motores cuja preparação da mistura se inicia fora da câmara de combustão, a etapa final desse processo certamente se dá em seu interior. O direcionamento do fluxo de mistura que entra no cilindro para as regiões mais aquecidas da câmara e os mecanismos de geração de turbulência são recursos comumente utilizados para tentar garantir uma completa atomização na etapa final do processo de formação da mistura (ZHAO et al., 1999).

Heywood (1988) mostrou que o fluxo turbulento de carga no interior do cilindro torna o processo de mistura e as taxas de transferência de calor inúmeras vezes maior do que no processo de difusão molecular. $\mathrm{O}$ autor sugere ainda recursos para geração de turbulência no interior do cilindro, como por exemplo, a criação de áreas de compressão (squish) para intensificar os níveis de turbulência na fase final do curso de compressão.

\section{1 ÁREA DE COMPRESSÃO E RESFRIAMENTO (SQUISH E QUENCH)}

A área de compressão e resfriamento é a porção paralela do pistão e do cabeçote que quase se tocam na fase final do curso de compressão. Essas superfícies possuem grandes áreas 
relativas ao pequeno volume contido entre elas. Consequentemente, há uma grande transferência de calor entre a mistura e assas superfícies (HEISLER, 1995).

Normalmente, a área de compressão (squish area) e de resfriamento (quench area) são coincidentes, diferenciando-se apenas pela funcionalidade (Figura 15). O fluxo radial gerado durante a compressão é chamado de "fluxo radial de compressão" (FRC), e o fluxo radial em sentido contrário ao FRC, gerado durante a expansão é chamado de "fluxo radial de expansão" (FRE).

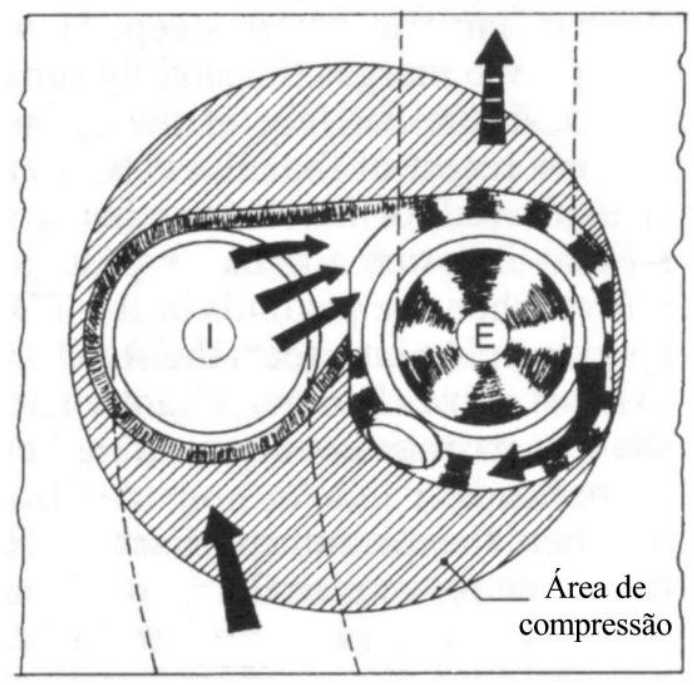

Figura 15 - Área de compressão (HEISLER, 1995).

O FRC também é conhecido como "squish", enquanto que o FRE é conhecido como "reverse squish".

\subsection{RELAÇÃO SUPERFÍCIE / VOLUME}

Para minimizar as perdas de calor na câmara de combustão e as emissões de hidrocarbonetos não queimados, a área superficial da câmara deve ser minimizada em relação ao seu volume. A relação superfície-volume é dada pela área da superfície da câmara dividida pelo volume da mesma. 
Um dos gráficos mostrados na Figura 16 traz a relação entre a emissão de hidrocarbonetos e a relação superfície / volume de uma câmara de combustão, onde é mostrado que quanto maior for a relação superfície / volume, maiores serão as emissões de hidrocarbonetos. Pode-se observar que o aumento da razão de compressão implica na diminuição do volume da câmara de combustão, para um dado curso do pistão e diâmetro do cilindro. Isto aumenta sua relação superfície-volume, resultando em maiores índices de emissões de hidrocarbonetos.
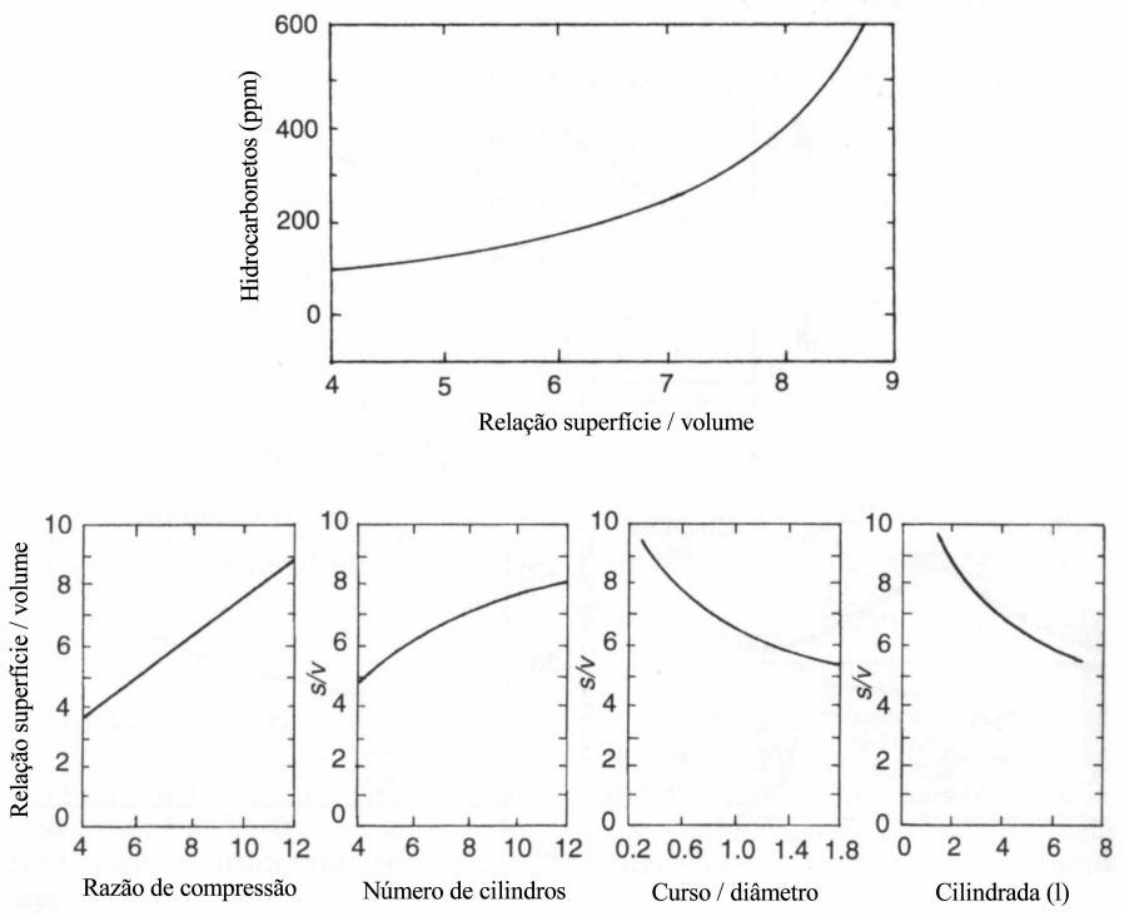

Figura 16 - Relação superfície-volume (HEISLER, 1995).

\subsection{RELAÇÃO CURSO / DIÂMETRO}

É a relação entre o curso do pistão no interior do cilindro e seu respectivo diâmetro. Quando essa relação é 1 o motor é dito quadrado; quando menor que 1 é dito super-quadrado; quando maior que 1 é dito sub-quadrado. 
Uma maior relação curso / diâmetro acarreta uma menor relação superfície / volume e, consequentemente, menor emissão de hidrocarbonetos.

Outros fatores como capacidade do cilindro e número de cilindros também afetam a relação superfície / volume, como pode ser visto na Figura 16. 


\section{A COMBUSTÃo NOS MOTORES DE IGNIÇÃO POR CENTELHA}

Devido à grande rapidez com que ocorre a combustão e às temperaturas muito elevadas, a observação dos processos químicos envolvidos é muito difícil. A despeito do prosseguimento das pesquisas nesse campo, as teorias sobre combustão e propagação da chama permanecem ainda bastante especulativas.

Segundo Taylor (1976), a composição química dos gases não queimados e a dos produtos da combustão podem ser determinadas após resfriamento. Entretanto, a evidência experimental indica que a transição entre esses estados envolve inúmeros compostos intermediários. Ele cita que uma possível teoria considera a combustão da mistura dependente das reações em cadeia, nas quais uns poucos constituintes altamente ativos (radicais) provocam reações que geram constituintes ativos adicionais somados aos produtos finais, multiplicando o número de reações até que a combustão seja completa, ou até que um ponto em que as reações de destruição das cadeias sejam mais fortes que as da formação de cadeias. Na frente de chama, as reações de formação da cadeia podem apenas atingir certa distância no interior da carga relativamente fria e não queimada antes de se partirem e, dessa forma, estabelece-se uma chama definida. Entretanto, se o gás não queimado se tornar quente o suficiente para manter a reação, o gás restante terá uma rápida autoignição. Na combustão normal de uma mistura homogênea, por exemplo, a que ocorre a volume praticamente constante, define-se uma frente de chama que se propaga desde a vela de ignição até as 
extremidades do cilindro, mas isso não se dá de forma tão simples, pois a elevação de pressão dos gases queimados comprime a parte não queimada da carga. Por essa razão, a carga não queimada próxima à frente de chama move-se em relação à câmara, sendo o movimento da chama a soma do movimento da chama para o interior de parte não queimada da carga e o movimento relativo à forma como a frente de queima é empurrada pela expansão dos gases queimados.

Judge (1965) mostra uma ilustração que representa as três regiões básicas de uma câmara de combustão, através das quais todo o processo de combustão se desenvolve (Figura 17).

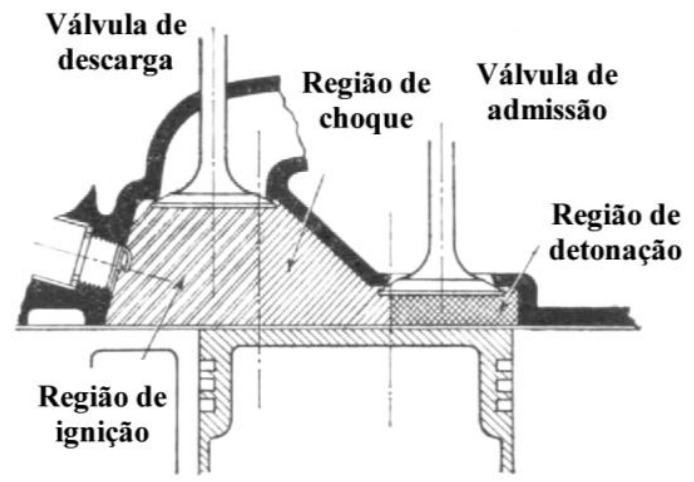

Figura 17 - Regiões da câmara de combustão (JUDGE, 1965).

A primeira região é conhecida como "região de ignição". Nessa região os materiais que compõem a câmara de combustão ficam por mais tempo expostos aos gases da combustão, onde os mesmos atingem máxima temperatura. O ideal é que essa região seja protegida contra perda de calor. A construção de câmara de combustão que utiliza vela de ignição próxima da válvula de descarga, além de aquecer a mistura para o início da combustão e aumentar a taxa de queima, ameniza as perdas de calor nessa região (JUDGE, 1965).

A segunda região é conhecida como "região de choque", pois nessa etapa da combustão o pistão passa pelo ponto morto superior e as partes móveis do motor estão sob grandes esforços 
mecânicos, devido às pressões atingidas nessa etapa. É desejável que a taxa de queima, e portanto, a taxa de elevação de pressão nessa região seja reduzida (JUDGE, 1965).

A terceira região é conhecida como "região de detonação", onde a relação superfície / volume local deve ser alta, para um controle satisfatório do fenômeno de detonação, por isso, também se costuma instalar a válvula de admissão nessa região (JUDGE, 1965).

Diversos trabalhos foram feitos a fim de se compreender melhor o processo de combustão nos motores de ignição por centelha (JANEWAY, 1929; ZINNER, 1939; ROTHROCK e SPENCER, 1939; ROTHROCK e BIERMANN, 1940; CARIS et al., 1955, etc.), assim sendo, os tópicos desse capítulo apresentarão alguns desses trabalhos.

\subsection{VELOCIDADE E PERCURSO DA FRENTE DE CHAMA, TAXA DE QUEIMA E DESENVOLVIMENTO DE PRESSÃO}

O desenvolvimento de pressão no cilindro do motor e sua consequente performance dependem da natureza da frente de chama, de sua velocidade, assim como da relação ar / combustível (ou combustível / ar), do grau de homogeneidade da mistura, avanço da centelha, rotação do motor, das ondas de choque, pré-ignição, efeito de detonação, etc.

Para fins de análise das curvas de pressão-tempo ou pressão-ângulo de manivela, costumam-se definir as seguintes grandezas:

Ângulo de queima (ou período de queima): período entre a centelha e uma fração de massa queimada em torno de $90 \%$;

Ângulo de atraso (ou período de atraso): período entre a ocorrência da centelha e o surgimento de uma elevação mensurável de pressão acima da pressão de compressão (motoring);

Ângulo efetivo de queima (ou período): ângulo de queima menos o ângulo de atraso; 
Velocidade média da chama: distância do ponto de disparo da centelha até a parte mais remota da câmara de combustão dividida pelo período de queima;

Segundo Heisler (1995), após a frente de chama atingir a parede do cilindro, ainda restará cerca de $25 \%$ da carga a ser queimada. Nesse estágio (pós-combustão), a taxa de queima, diminuída pela carência de oxigênio, pelas trocas de calor com a parede e pela superfície mais fria do pistão, provoca um rápido decréscimo da curva de pressão.

\subsubsection{Efeito da Rotação do Motor}

Trabalhos desenvolvidos por Marvin et al. (1936); Rothrock e Spencer (1939); mostram que a velocidade da chama aumenta quase que proporcionalmente ao aumento da rotação do motor, bem como o aumento da taxa de queima, por causa do aumento dos níveis de turbulência no sistema de admissão e interior da câmara. Dessa forma, o ângulo de queima permanece praticamente constante.

Sem essa característica, os motores de ignição por centelha não poderiam operar a velocidades do pistão muito elevadas, como as usadas nos motores atuais.

Segundo HEISLER (1995), velocidades típicas da frente de chama nos motores atuais encontram-se entre $15 \mathrm{~m} / \mathrm{s}$ em marcha lenta e $70 \mathrm{~m} / \mathrm{s}$ a $6000 \mathrm{rpm}$.

\subsubsection{Efeito da Pressão de Admissão}

A velocidade da chama aumenta com o aumento da pressão inicial de admissão, justificado pela diminuição do ângulo de queima medido no eixo do virabrequim. Isso explica por que é necessário avançar a centelha para os motores que operam em cidades de grandes altitudes (FIOCK et al., 1940). 


\subsubsection{Efeito da Razão entre as Pressões de Descarga e Admissão}

A diluição da carga com um gás inerte reduz a velocidade da chama, por isso, o aumento da relação entre a pressão de descarga e a de admissão aumenta a fração de gás queimado presente na carga, e dessa forma, reduz a velocidade da chama, implicando na necessidade do avanço da centelha (FIOCK et al., 1940).

\subsubsection{Efeito da Relação Combustível / Ar}

A velocidade da chama aumenta com o enriquecimento da mistura. Para misturas muito pobres, a velocidade da chama pode ser tão lenta a ponto de se extinguir. O limite de pobreza depende da composição do combustível, do projeto do motor e das condições de operação.

Gerrish e Voss (1940) mostraram o efeito da relação combustível-ar no avanço da centelha e na performance do motor (Figura 18). Nesse ensaio, a Imep máxima se deu para uma relação combustível / ar de $0.082(\mathrm{~A} / \mathrm{C}=12,2)$. Nota-se que para misturas mais ricas o avanço da centelha não tem efeito significativo sobre a performance do motor e como o consumo específico, enquanto que para misturas mais pobres, o avanço da centelha tem expressivo efeito sobre os dois aspéctos. 


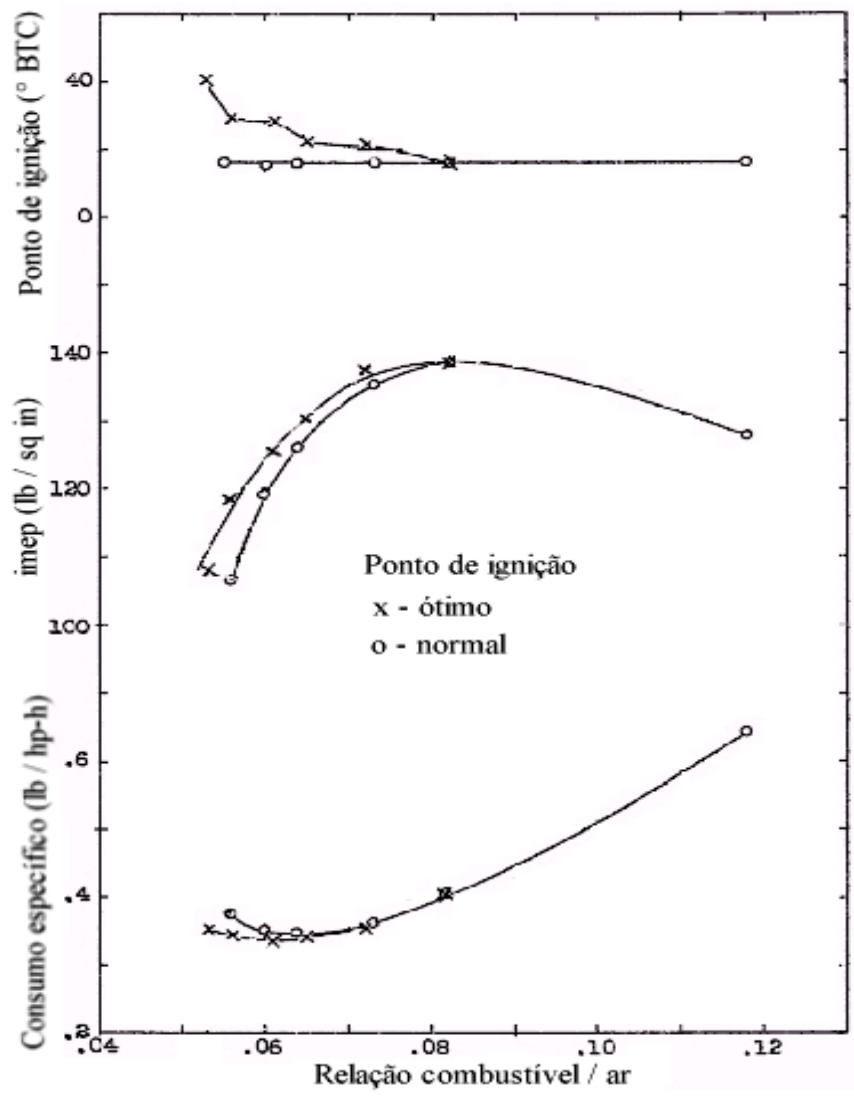

Figura 18 - Efeito da relação combustível / ar no avanço da centelha e performance do motor (GERRISH e VOSS, 1940).

\subsubsection{Efeito do Número e Posições das Velas de Ignição na Câmara de Combustão}

Marvin et al. (1935) levantaram a curva de pressão no interior do cilindro contra o ângulo de manivela para um motor com o avanço da centelha fixo, para diversas velas em diferentes posições, operando simultaneamente ou individualmente. A Figura 19 mostra sete ensaios feitos com diferentes configurações de velas, onde fica nítida a vantagem de se utilizar uma vela centralizada, pois se obtem maiores níveis de pressões no cilindro, devido ao menor percurso da frente de chama, o que gera maior taxa de elevação de pressão no interior da câmara de combustão. Esse efeito também é notado nos ensaios 6 e 7, onde foram utilizadas duas velas opostas. Eles igualmente mostraram que uma vela de eletrodo mais longo gera uma taxa de elevação de pressão maior do que a encontrada com uma vela de eletrodo mais curto, embora isso não diminua o período de queima. 
É importante observar que, embora o efeito da posição da vela de ignição no interior da câmara seja significativo, ele está essencialmente relacionado ao menor ângulo de queima e à maior taxa de elevação de pressão, pois essas propriedades podem ser manipuladas de outras formas como, por exemplo, aumentando-se a velocidade da frente de chama por meio de geração de maior índice de turbulência da mistura previamente preparada.
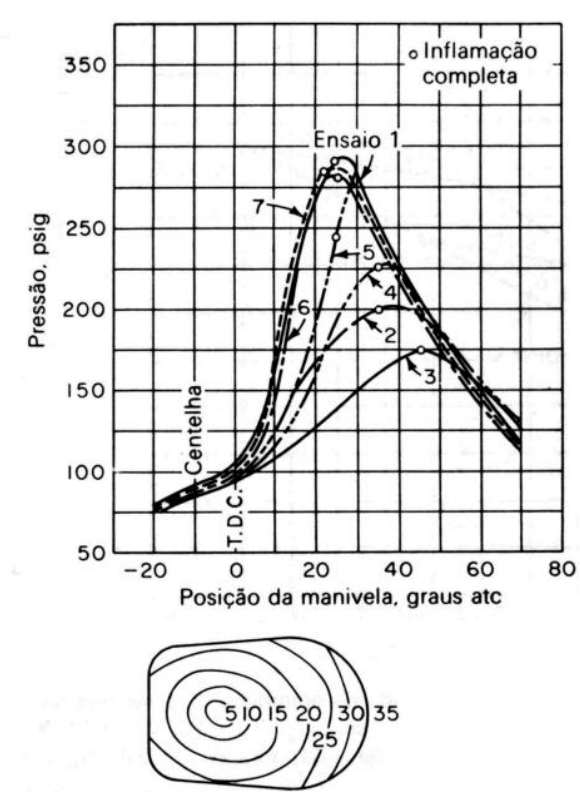

Ensaio 1
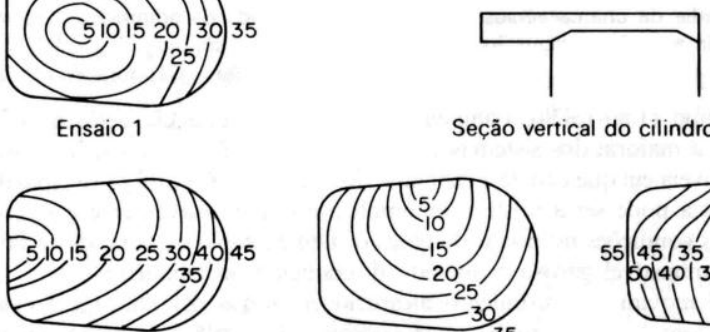

Ensaio 2

Seça vertical do cilindro

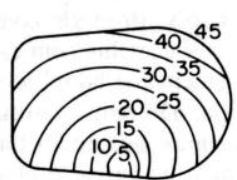

Ensaio 4

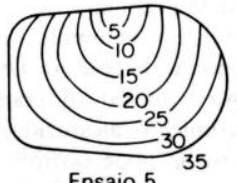

Ensaio 5

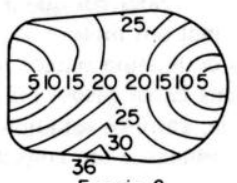

Ensaio 6

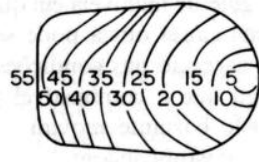

Ensaio 3

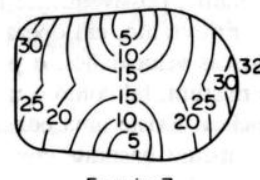

Ensaio 7

Figura 19 - Efeito do número e posições das velas de ignição sobre a performance do motor (MARVIN et al., 1935).

Diggs (1953) mostrou que o tempo de queima com dezessete velas de ignição igualmente distribuídas na câmara de combustão de seu motor era aproximadamente a metade do tempo obtido com uma só vela posicionada para se ter o menor tempo de queima possível. 
Swett Jr. (1949) mostrou que a vela de ignição no interior da câmara de combustão, para gerar ignição satisfatória (sem falhas), deve estar localizada numa região de baixa velocidade do fluxo de mistura e de baixa turbulência.

\subsection{PRÉ-IGNIÇÃO}

Muitos estudos têm sido feitos para se entender o mecanismo da pré-ignição e os efeitos dos diversos tipos de combustíveis nesse fenômeno. Alguns mecanismos de prevenção têm sido buscados para evitar esse fenômeno nocivo aos motores de combustão interna, tais como: a redução da temperatura da câmara de combustão em altas rotações e em plena carga, por meio do enriquecimento da mistura; ajuste adequado do grau térmico das velas de ignição; redução do acúmulo de depósitos na câmara, etc.

Segundo Mogi et al. (1998), pré-ignição é a ignição da mistura ar-combustível pelo contato com superfícies superaquecidas na câmara de combustão como, vela de ignição, depósitos, etc. Eles mostraram que a pré-ignição ocorre preferencialmente a altas razões de compressão e $\lambda$ em torno de 1 (Figura 20).

4800 RPM WOT Combustível de 96 octanas

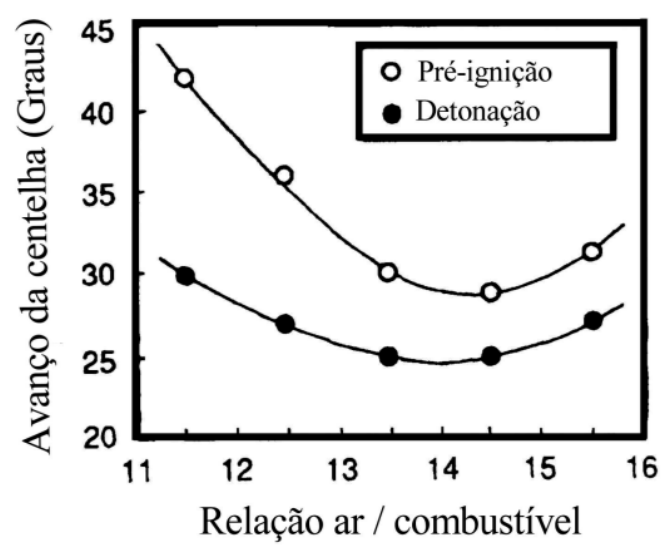

Figura 20 - Efeito da relação ar-combustível sobre os fenômenos de pré-ignição e detonação (MOGI et al., 1998). 


\subsection{DETONAÇÃO}

Embora pré-ignição e detonação sejam efeitos do mesmo tipo de combustão anormal e ocorrerem geralmente sob condições semelhantes, elas são fenômenos substancialmente diferentes.

A detonação é o efeito da ignição espontânea dos gases não queimados na região de detonação da câmara de combustão (end zone), onde altos gradientes de temperatura e pressão são gerados durante o curso da frente de chama, acarretando na propagação de ondas de pressão de altas amplitudes e frequências no interior da câmara de combustão.

Mogi et al. (1998) também apresentaram uma proposta de prevenção de pré-ignição pela estratégia de controle de detonação, porque eles perceberam que a detonação sempre precede a pré-ignição (Figura 20). Dessa forma, ao se detectar o início da detonação, a mistura deve ser imediatamente enriquecida para promover o resfriamento dos pontos quentes no interior da câmara de combustão.

Lee (1938) mostrou que o aumento da temperatura da mistura é acompanhado de um acentuado decréscimo da taxa de compressão necessária para a ocorrência de detonação.

Rothrock e Biermann (1940) mostraram que a detonação depende da densidade e da temperatura do gás na região de detonação da câmara de combustão, onde a densidade máxima do gás nessa região, imediatamente antes de detonar, é dada por:

$$
\rho_{3}=\frac{R p_{1}}{K T_{1}}\left(1+\frac{H}{c_{V} T_{1} R^{\gamma-1}}\right)^{\frac{1}{\gamma}}
$$

Sendo $\rho_{3}$ a densidade do gás imediatamente antes de detonar; $p_{1}$, a pressão do ar de admissão; $T_{1}$, a temperatura do ar de admissão; $\gamma$, o coeficiente adiabático; $c_{V}$, o calor específico da mistura a volume constante; $R$, a taxa de compressão; $H$ e $K$, constantes.

O valor máximo da temperatura do gás extremo seria então dado por: 


$$
T_{3}=T_{1} R^{\gamma-1}\left(1+\frac{H}{c_{V} T_{1} R^{\gamma-1}}\right)^{\frac{\gamma-1}{\gamma}}
$$

Sanders e Peters (1945) mostraram testes feitos com um combustível de 100 octanas em um motor arrefecido a ar, sob duas condições distintas de relação combustível-ar, A temperatura do cabeçote praticamente não teve efeito sobre a detonação quando misturas ricas foram usadas, mas mostrou uma considerável influência sob misturas pobres. (Figura 21).

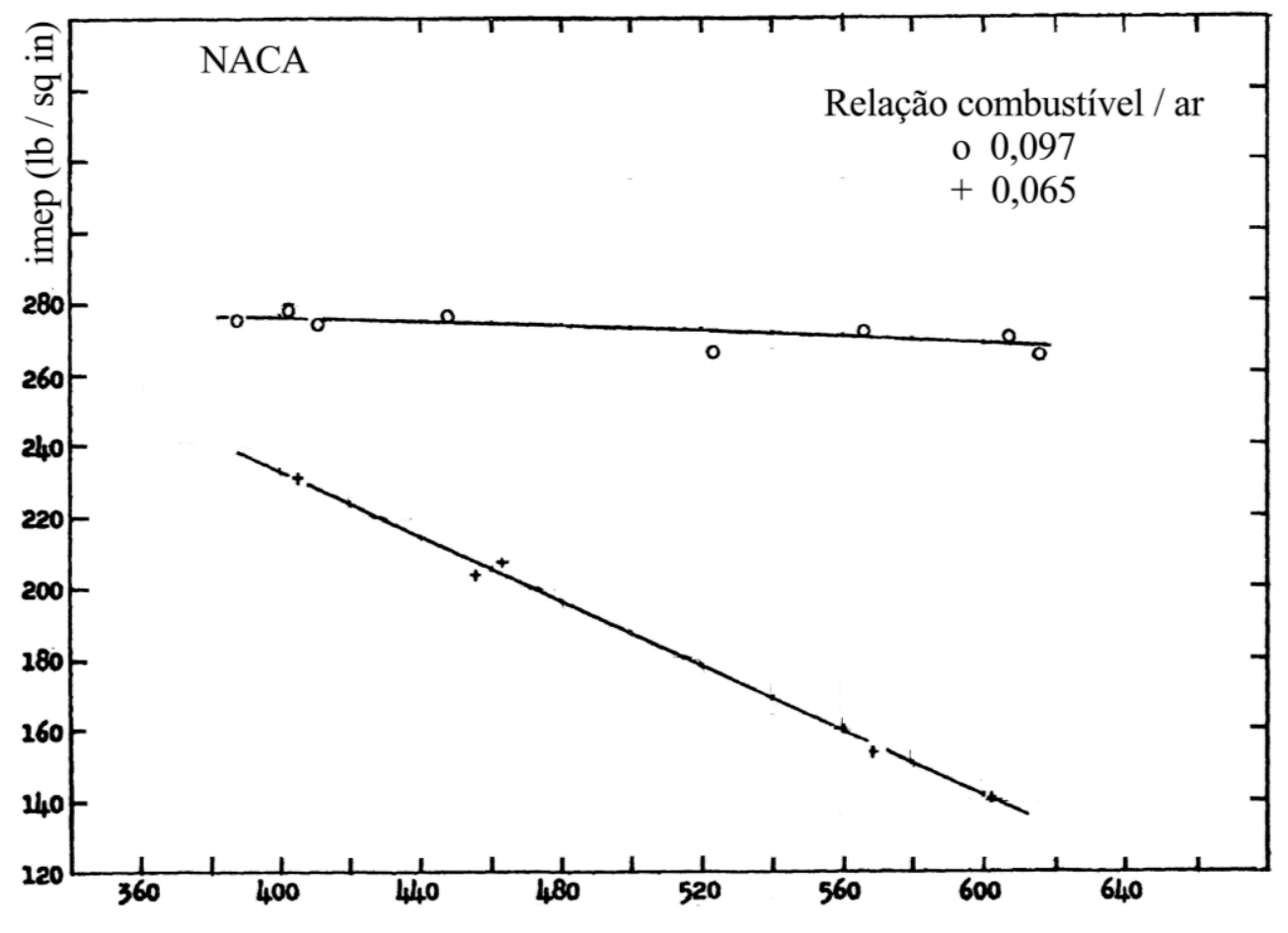

Temperatura na vela de ignição $\left({ }^{\circ} \mathrm{F}\right)$

Figura 21 - Influência da temperatura do cabeçote sobre o fenômeno de detonação, para misturas ricas e pobres (SANDERS e PETERS, 1945).

\subsection{EMISSÕES DE POLUENTES}

Segundo Pagliuso (2003), poluentes são substâncias que existem em concentrações inadequadas, em determinados momentos e locais, e que por vezes ultrapassam a capacidade de reciclagem natural do planeta. 
Os poluentes do ar podem ser divididos basicamente em duas categorias, a dos poluentes gasosos e a dos materiais particulados. Nesta segunda categoria, estão incluídos tanto sólidos como líquidos.

De modo geral, todo processo de combustão libera água, dióxido de carbono, monóxido de carbono, hidrocarbonetos, óxidos de nitrogênio, etc.

O dióxido de carbono não é considerado tecnicamente um poluente por ter pouco efeito direto sobre a vida e a propriedade, porém, tem sido apontado como um dos principais responsáveis pelo principal aumento do efeito estufa que pode conduzir a uma elevação geral da temperatura do planeta.

O monóxido de carbono é produto da oxidação parcial do carbono durante o processo de combustão devido à falta de oxigênio na mistura ou mesmo pela sua não homogeneidade.

Os óxidos de nitrogênio são produtos da oxidação do nitrogênio quando a temperatura na câmara excede $900^{\circ} \mathrm{C}$.

As emissões de hidrocarbonetos são consequência da queima incompleta dos combustíveis durante o processo de combustão.

O Programa de Controle de Poluição do Ar por Veículos Automotores (PROCONVE) Resolução n. ${ }^{\circ}$ 18/86 do Conselho Nacional do Meio Ambiente (CONAMA), a partir de 1988, estabeleceu limites máximos de emissão de gases poluentes $(\mathrm{CO}, \mathrm{HC}, \mathrm{NOx}, \mathrm{CHO}$, emissões evaporativas e material particulado) que devem ser respeitados por todo veículo produzido no país ou importado. Estes limites são modificados de tempos em tempos e se tornam cada vez mais rigorosos.

Esses poluentes causam vários efeitos sobre a saúde humana, a saber:

Monóxido de Carbono (CO): Liga-se à hemoglobina, substância do sangue que leva oxigênio ao corpo, formando a carboxihemoglobina e diminuindo a oxigenação do sangue. Causa tontura e vertigens e pode ser fatal em ambiente fechado; 
Hidrocarbonetos (HC): Considerados carcinogênicos e mutagênicos. Provocam irritação nos olhos, nariz, pele e aparelho respiratório;

Aldeídos (CHO): Irritação dos olhos, nariz e garganta (possíveis agentes carcinogênicos);

Óxidos de Nitrogênio (NOx): Desconforto respiratório, diminuição da resistência a infecções e alterações celulares.

Os gráficos da Figura 22 mostram os valores impostos pela norma de controle de emissões para diferentes épocas e os respectivos valores conseguidos pelos veículos com diferentes combustíveis no país:
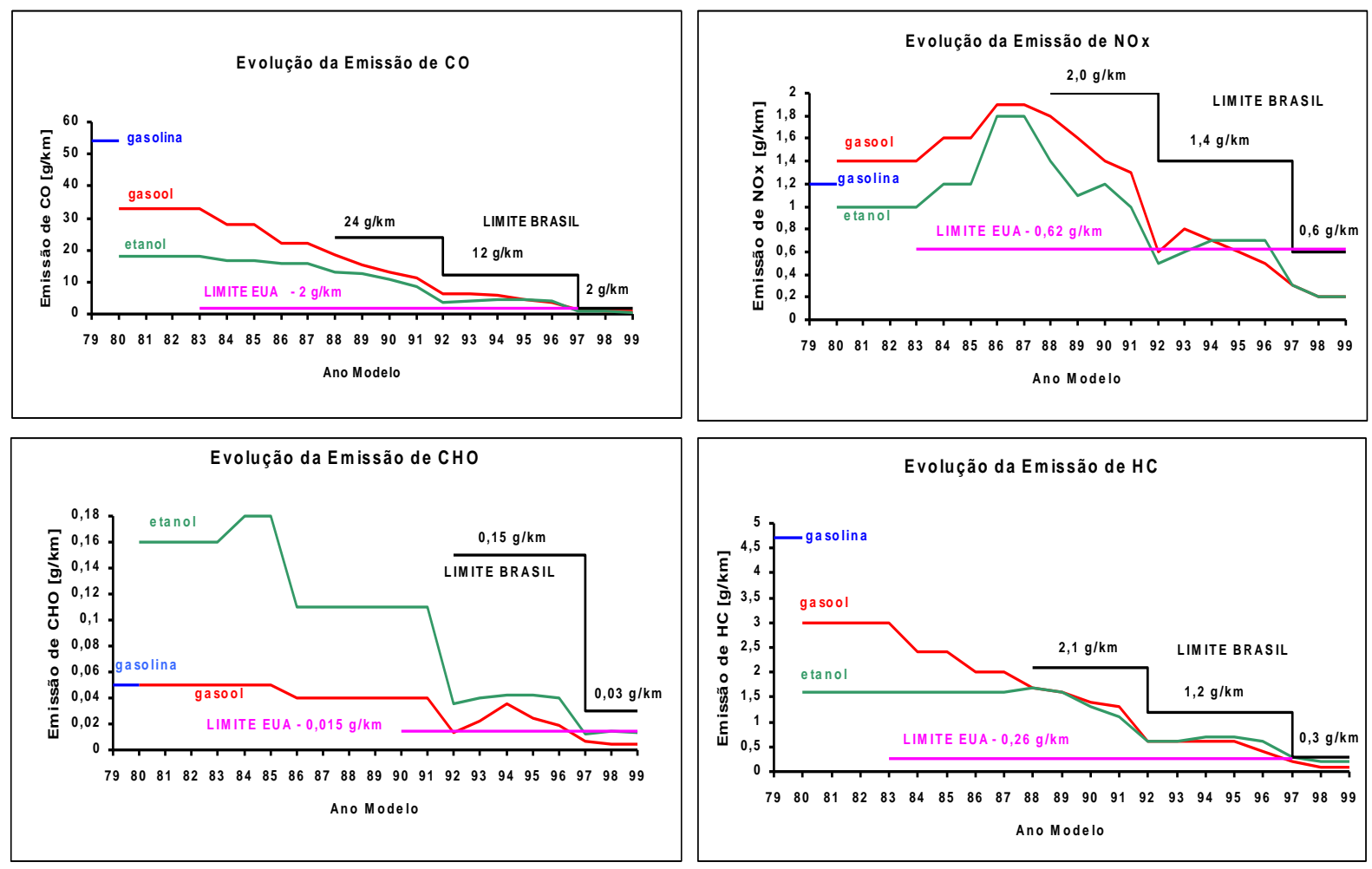

Figura 22 - Controle de emissões (http://www.ambiente.sp.gov.br).

\subsection{INFLUÊNCIA DA CÂMARA DE COMBUSTÃO SOBRE A PERFORMANCE E EMISSÕES DO MOTOR}


Caris et al. (1956) afirmaram que o aumento da rotação diminui o "requerimento de octanas" (número de octanas mínimo requerido de um combustível para que o motor opere na iminência de detonar em um dado regime), diminuindo as chances de ocorrer detonação. Isto pode ser visto na Figura 23, que compara dois tipos de câmara de combustão, uma plana (X) e outra em forma de cunha (Y). Na medida em que se aumenta a rotação do motor, diminui-se a tendência a detonar, fato justificado pelo aumento do nível de turbulência na câmara de combustão que aumenta a velocidade da frente de chama e diminui o tempo de queima. A influência da geometria da câmara de combustão é nitidamente percebida pelo fato da diferença dos requisitos de octanas entre a câmara em forma de cunha e a plana permanecer em torno de 10 octanas para todos os regimes de rotação. O menor percurso da frente de chama e a área de resfriamento na extremidade da câmara, oposta à vela de ignição, proporciona à câmara em cunha essa enorme vantagem relativa à câmara em disco. Eles também mostraram a relação entre o requisito de octanas de uma câmara de combustão e o ângulo de queima, temperatura e pressão do gás na zona extrema (Figura 24), evidenciando uma relação linear entre o ângulo de queima e o requisito de octanas.

Ficou mostrado também que, um curto percurso da chama, altos níveis de turbulência e concentração da carga na região da vela de ignição geram altas taxas de queima, diminuindo o tempo de queima.

Na Figura 25, Caris et al. (1956) mostram o efeito da geometria da câmara de combustão no período de queima para dois tipos de câmaras, uma do tipo plana (A) e outra do tipo côncava na cabeça do pistão (B). Observou-se que no tipo (A) era necessário $50^{\circ}$ do eixo de manivela para a queima total da mistura, enquanto que o tipo (B) requeria apenas $27^{\circ}$.

A conclusão mais importante desse trabalho é que embora um tempo de queima mais curto aumente a temperatura e a pressão do gás na zona extrema da região de detonação, 
fatores estes que tendem a gerar detonação, a diminuição mais acentuada do próprio tempo de queima tem efeito dominante sobre tais variáveis, diminuindo assim o requisito de octanas.

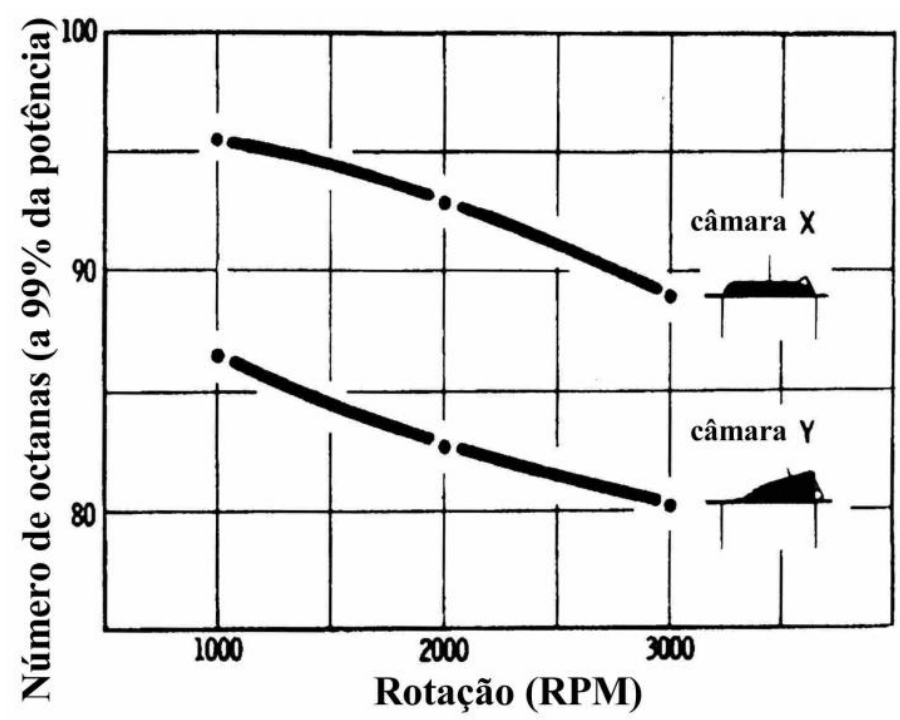

Figura 23 - Efeito da rotação sobre o requisito de octanas (CARIS et al., 1956).

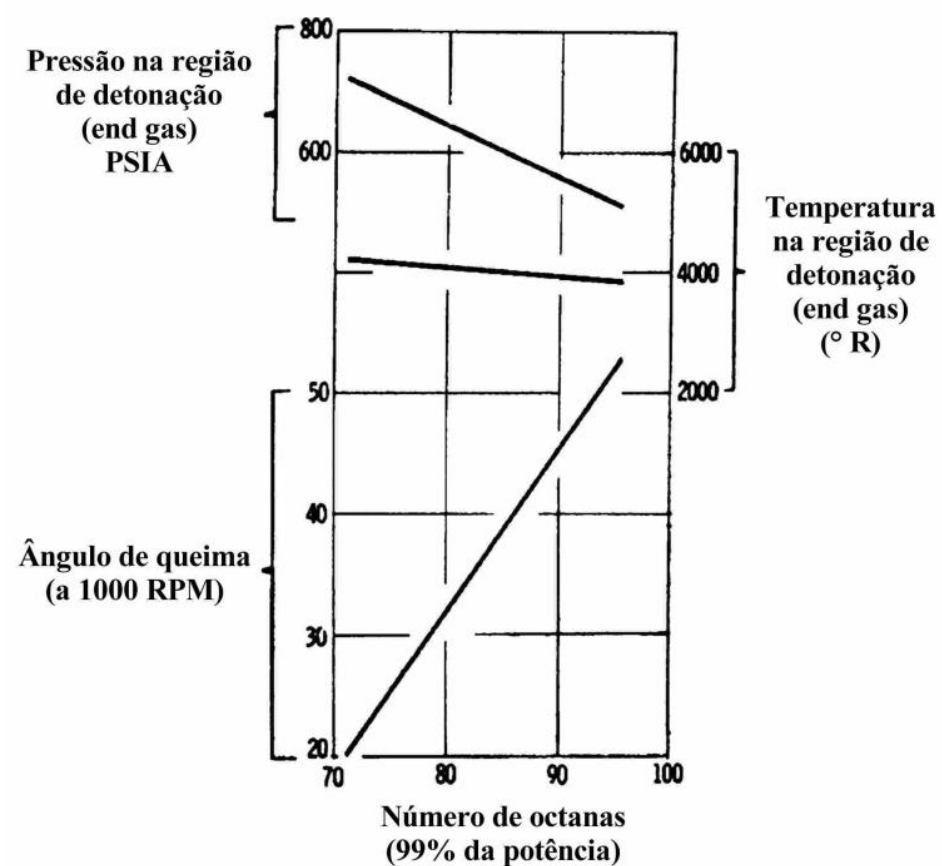

Figura 24 - Influência do requisito de octanas sobre o tempo de queima, temperatura e pressão do gás na zona extrema (CARIS et al., 1956). 


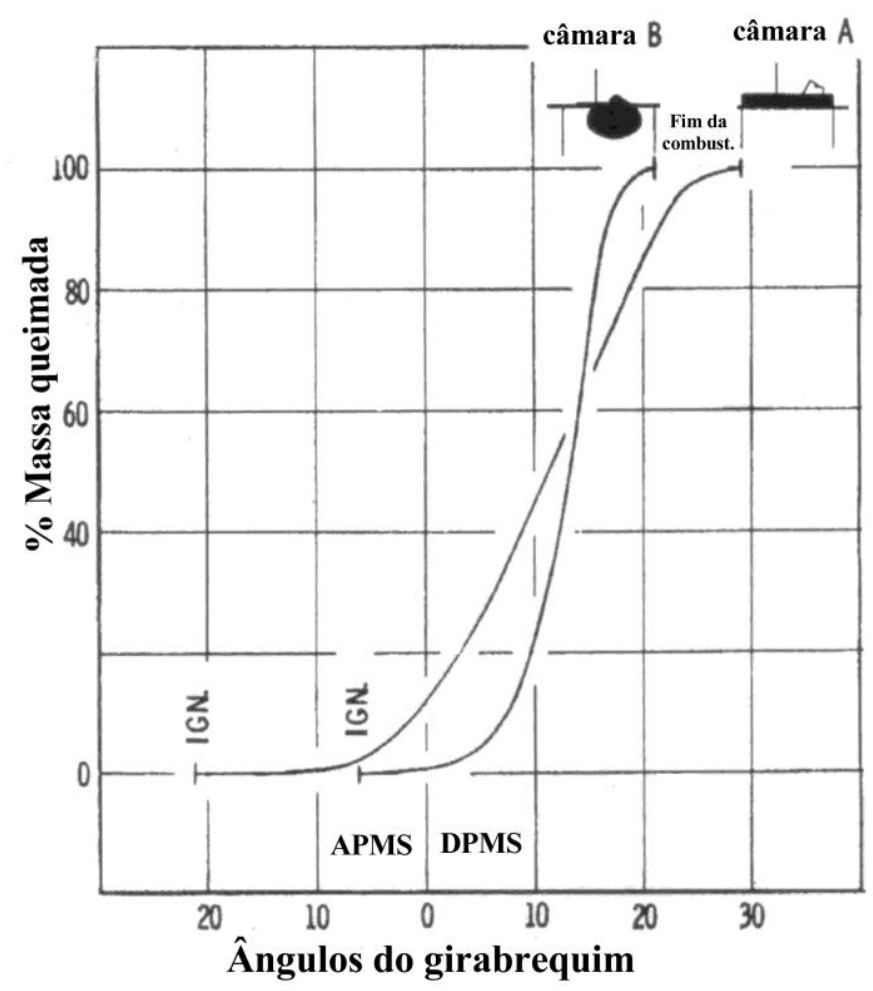

Figura 25 - Efeito da geometria da câmara de combustão sobre o período de queima (CARIS et al., 1956).

A câmara "Y" da figura 23 e a câmara "B" da figura 25, embora tenham se mostradas eficientes em diversos aspectos, normalmente possuem áreas de resfriamentos bem maiores do que a da câmara "X" e da câmara "A", ocasionando maiores índices de emissões poluentes (HEISLER, 1995).

Diggs (1953) também estudou as variáveis: pressão, temperatura, e tempo de queima, e também reportou efeitos similares. Ou seja, uma câmara de combustão que proporciona curto período de queima é também uma câmara que permite uso de combustível de menor octanagem.

Janeway (1929) mostrou que intensifica os níveis de turbulência na câmara, eleva a taxa de queima, aumenta a velocidade dos gases não queimados, melhora a taxa de troca de calor com as superfícies da câmara e parede do cilindro e diminui a tendência a detonar. 
Caris et al. (1956) mostraram que diminuir o espaçamento (gap) entre o topo do pistão e o cabeçote na área de compressão (squish), mantendo-se constante a razão de compressão, diminui o requisito de octanas (Figura 26).

O maior resfriamento provocado pelo FRE (fluxo radial de expansão) durante o avanço da frente de chama nessa região de menor volume (gap) pode extinguir a chama, ocasionando maiores índices de emissões poluentes (hidrocarbonetos não queimados) (HEISLER, 1995).

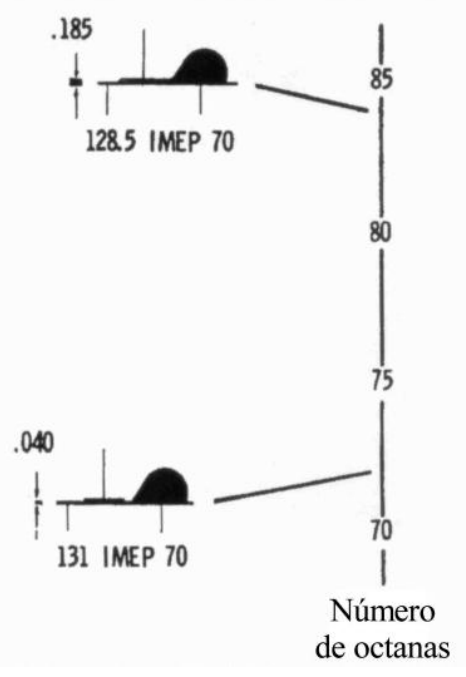

Figura 26 - Efeito do gap na área de compressão sobre o requisito de octanas (CARIS et al., (1956).

Heron e Felt (1950) também estudaram em detalhes esse efeito. Eles mostraram que no movimento de descida do pistão, a frente de chama é acelerada em direção à parede do cilindro, o que reduz o tempo de queima, onde o aumento da área de compressão e a diminuição do espaçamento, anteriormente citado, acentuam esse efeito.

Ueda et al. (1999) compararam o efeito da área de compressão inclinada (slant squish), ideal para câmara em forma de telhado (pentroof), com a área de compressão plana (convencional) sobre a performance do motor. Com a área de compressão inclinada (Figura 27), o requisito de octanas é diminuído, o torque é melhorado em todas as rotações, e o consumo específico diminuído (Figura 28). O FRE, com alta velocidade e turbulência, acelera 
a frente de chama em direção à parede do cilindro sobre a área de compressão (resfriamento), aumentando o efeito antidetonante, além de diminuir o ângulo de queima.

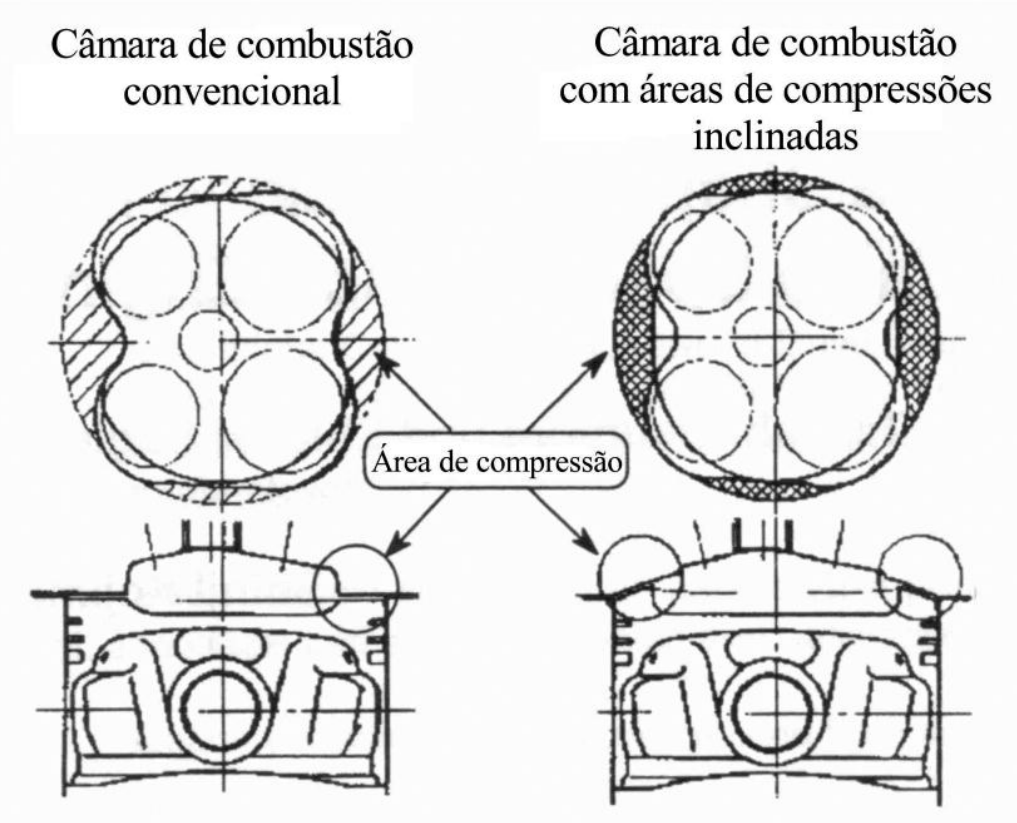

Figura 27 - Área de compressão inclinada e plana (UEDA et al., 1999). 

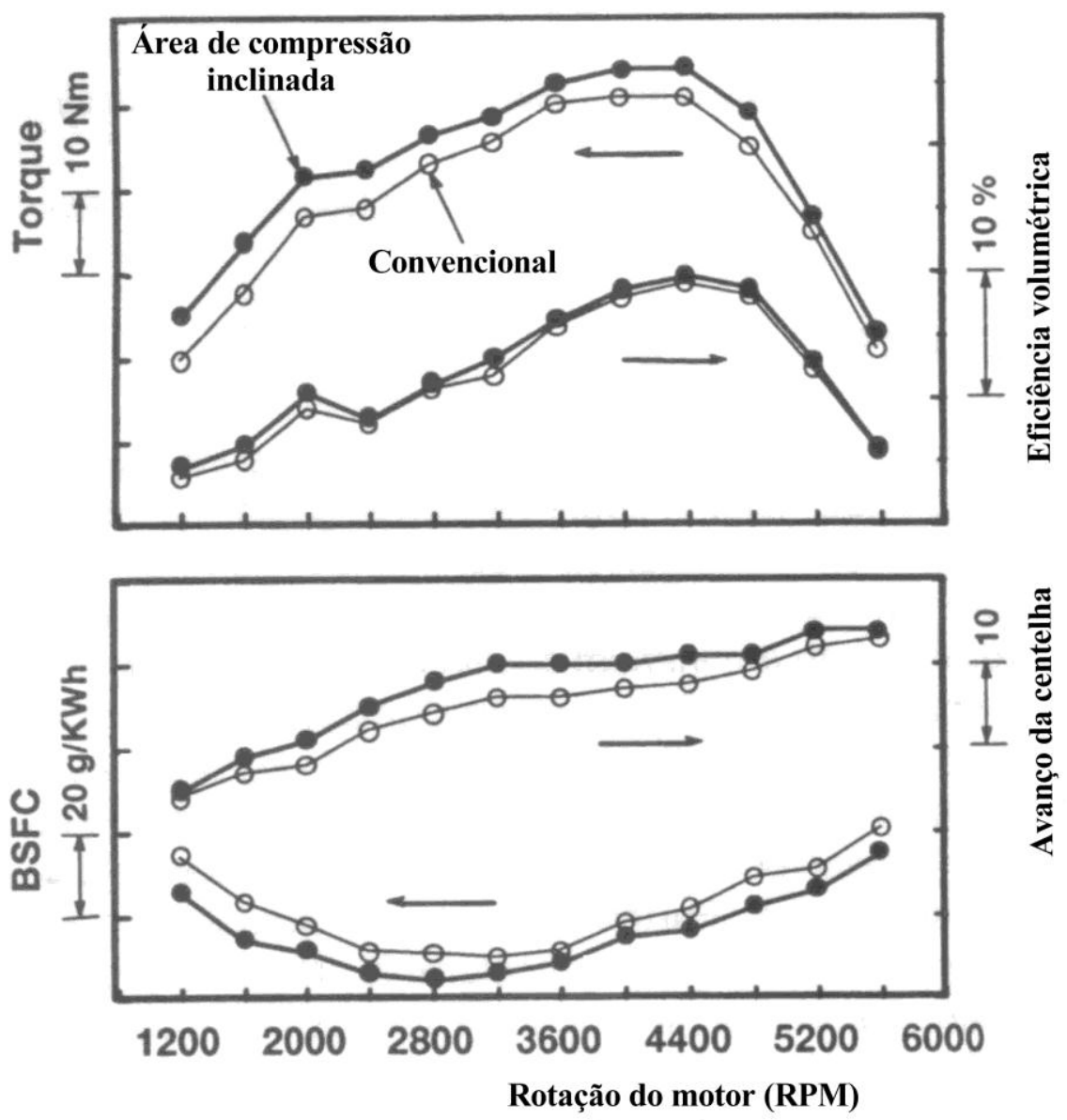

Figura 28 - Efeito da área de compressão inclinada sobre a performance do motor (UEDA et al., 1999).

Fujimoto et al. (2002) mediram o efeito do pistão com $20 \%$ de área de compressão na região da válvula de admissão (intake squish piston), assim como na área de descarga (exhaust squish piston) sobre o FRV, o FRC e o FRE no interior de cilindro, e suas respectivas influências no ângulo de queima e controle de detonação (Figura 29). 


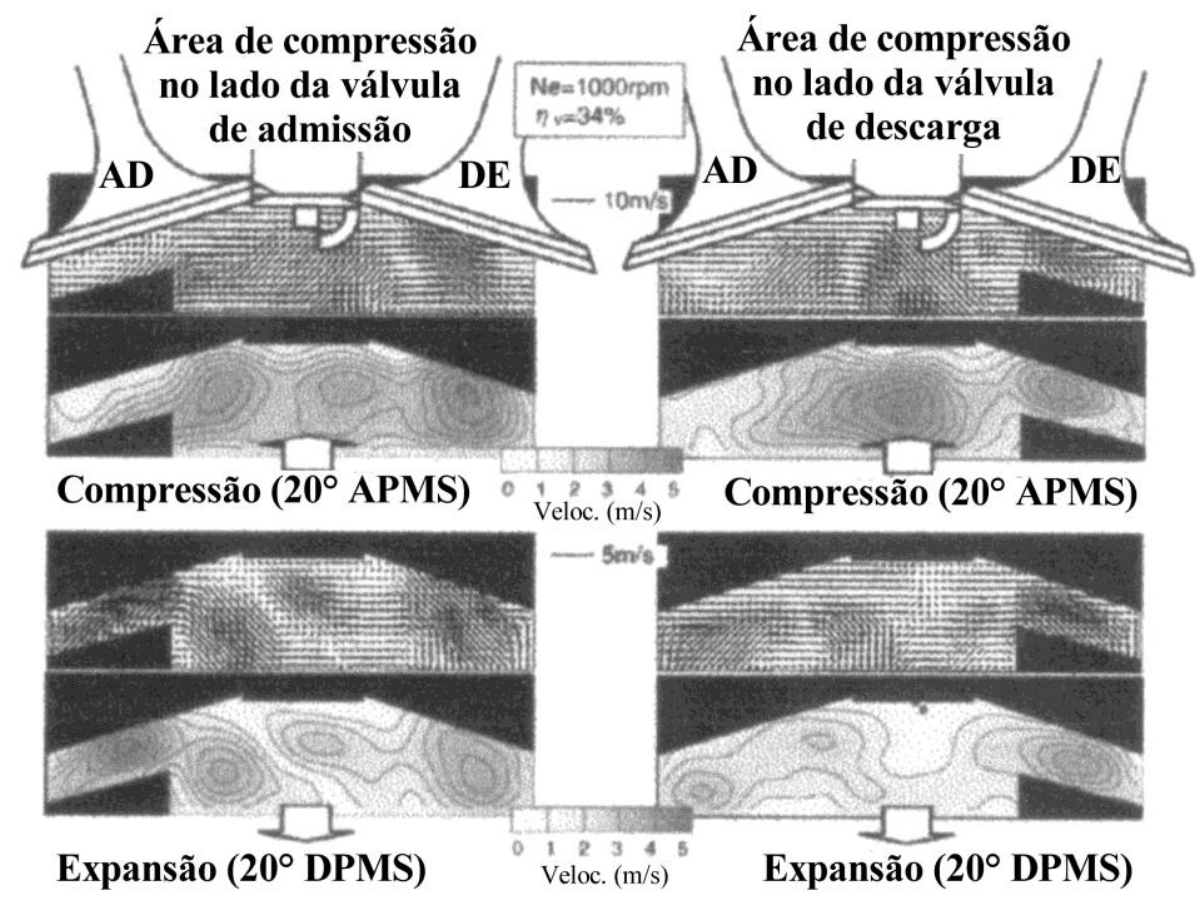

Efeito da localização da área de compressão na geração de FRC, FRE e FRV

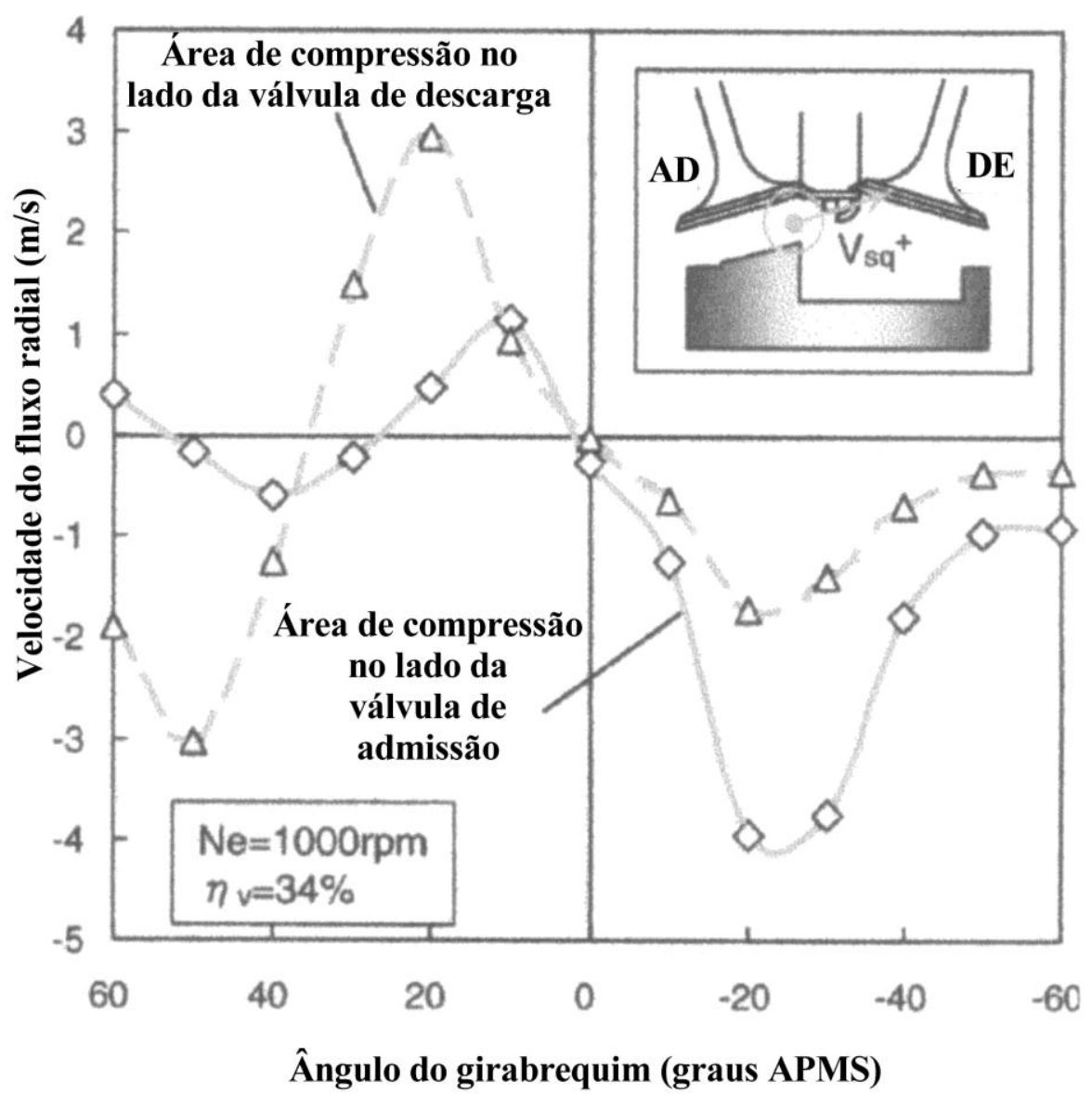

Figura 29 - Efeito da localização da área de compressão (FUJIMOTO et al., 2002). 
Fujimoto et al. (2002) concluiram que:

- Quando a área de compressão é localizada no lado da válvula de descarga, o FRV é colapsado ao final do curso de compressão, devido ao intenso fluxo vindo da área de compressão (FRC), enquanto que para a localização no lado da válvula de admissão o efeito do FRC, embora mais fraco, intensifica o FRV. Como o FRE (gerado quando o pistão começa a descer) é mais intenso, a frente de chama se acelera em direção à parede do cilindro na etapa final do processo de combustão, o que tem o efeito de diminuir o ângulo de queima;

- Com a área de compressão no lado da válvula de admissão, a alta taxa de troca de calor ao final da combustão, devido ao acentuado FRE, possui efeito antidetonante;

Em resumo, podem-se considerar alguns fatores que afetam o desenvolvimento da chama e sua propagação no interior da câmara de combustão, como: a geometria da câmara de combustão; a localização da vela de ignição; as características do fluxo de carga e sua correspondente geração de turbulência durante o processo de formação de mistura; o nível de turbulência durante a combustão; a relação ar / combustível; a diluição por gases queimados; a temperatura e pressão, etc.

A geometria da câmara de combustão determina o desenvolvimento da área superficial da frente de chama durante a combustão, regulando as taxas de queima em suas diferentes regiões, em função dos requisitos de performance, suavidade de funcionamento, economia de combustível, emissões poluentes, etc.

Heywood (1988) reportou que as câmaras de cavidades nos pistões e câmaras hemisféricas chegam a gerar áreas superficiais das frentes de chama cerca de 30 por cento maiores do que as geradas por câmaras do tipo "disco" sob iguais condições de operação, e 
que o posicionamento da vela de ignição para uma dada câmara de combustão tem efeito ainda mais significativo, de forma que uma câmara hemisférica com vela de ignição central possui o valor máximo da área da frente de chama cerca de 75 por cento maior do que para a mesma câmara com vela de ignição instalada lateralmente.

A taxa de queima aumenta com o nível de turbulência na câmara de combustão, entretanto a eficiência da combustão em uma câmara de alta turbulência é menor do que em uma câmara convencional, sob mesmas condições de operação, devido às maiores trocas térmicas da combustão turbulenta. Poulos e Heywood (1983) mostraram que previsões feitas através de modelagem computacional para a taxa de queima e a eficiência da combustão, para uma dada câmara de combustão e condição de funcionamento, indicaram que enquanto o tempo de queima decrescia cerca de um terço devido à maior turbulência, a eficiência da combustão decrescia cerca de $6 \%$. Isso mostra que sempre é necessário se considerar uma relação de compromisso entre o requisito de performance e eficiência da combustão. 


\section{ESTADO DA ARTE DAS CÂMARAS DE COMBUSTÃO}

\subsection{ASPÉCTOS GERAIS DOS PROJETOS DAS CÂMARAS DE COMBUSTÃO}

Os cabeçotes planos acomodam válvulas menores do que os dos tipos hemisféricos, cujas inclinações das válvulas normalmente se encontram entre $20^{\circ}$ e $40^{\circ}$. Um método de melhorar o enchimento do cilindro é construir cabeçotes multiválvulas, onde mesmo havendo a necessidade de se diminuir o tamanho de cada válvula, a área total de enchimento é aumentada. Com o aumento do número de válvulas, diminui-se a área de compressão disponível, muito importante na geração de turbulência e resfriamento da região de detonação da câmara de combustão. Dessa forma, diversos fatores devem ser levados em consideração nos projetos das câmaras de combustão.

Diferentes requisitos e aspectos evolutivos dos projetos de câmaras de combustão podem ser observados a seguir:

\subsubsection{Câmara Tipo "T"}

Câmara utilizada nos motores mais antigos (1901), quando não se utilizavam válvulas no cabeçote, e parecia bem natural empregar o sistema de descarga afastado do sistema de admissão. Embora já se conhecesse o fenômeno de detonação, as suas causas ainda pareciam obscuras, ou seja, detalhes como influência do longo percurso da frente de chama e tempo de queima não pareciam ser levados em consideração nos projetos dessas câmaras de combustão.

A Figura 30 mostra um exemplo desse tipo de configuração. 


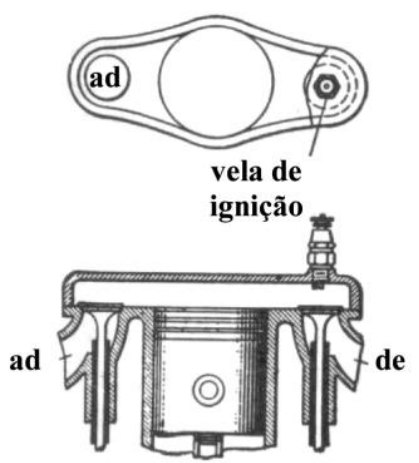

Figura 30 - Câmara tipo “T” (MALEEV, 1945).

Durante o curso de admissão, parte da mistura fresca, que vem da válvula de admissão, entra no compartimento do cilindro, e outra parte percorre um longo trajeto até a região da válvula de descarga, onde está instalada a vela de ignição. Ao final do curso de compressão, a mistura é impelida para as regiões das válvulas, com níveis consideravelmente baixos de turbulência se comparados com os níveis alcançados com outras câmaras em etapas seguintes. O aquecimento da mistura pela válvula de descarga garante boa atomização e alta taxa de queima na região de ignição. O longo percurso da frente de chama e, consequentemente longo período de queima, acarretam um alto requisito de octanas, a fim de evitar o fenômeno de detonação. Por isso, as razões de compressões utilizadas pelos motores com essa câmara eram as mais baixas da época (LICHTY, 1967).

\subsubsection{Câmara Tipo "L"}

Segundo Maleev (1945), esse tipo de câmara resulta do melhoramento da câmara tipo “T”, com respeito ao mecanismo de acionamento de válvulas e controle de detonação. Com a válvula de admissão instalada no mesmo lado da válvula de descarga, o percurso da frente de chama é diminuído, implicando em menor requisito de octanas, porém muito distante do conseguido por motores com válvulas no cabeçote. 
A câmara tipo "L" de alta turbulência, típica de 1919, foi desenvolvida por Ricardo (RICARDO, 1945), sendo ele o pioneiro no estudo do fenômeno de detonação. Essa câmara traz modificações importantíssimas para as tradicionais câmaras de combustão, como, área de compressão (resfriamento) na região de detonação e perfil hemisférico na região de combustão, conseguindo-se altas taxas de queima e melhor controle de detonação.

É importante lembrar que a queima não se dá exatamente a volume constante, o que implica que a combustão continua na região de detonação. Embora se diga com frequencia que a construção de área de compressão diminua o percurso da frente de chama, isso deve ser observado com cautela.

A Figura 31 ilustra dois tipos de câmaras tipo "L", sendo a ilustração "a" referente à câmara de baixa turbulência, e a "b" a câmara de alta turbulência desenvolvida por Ricardo
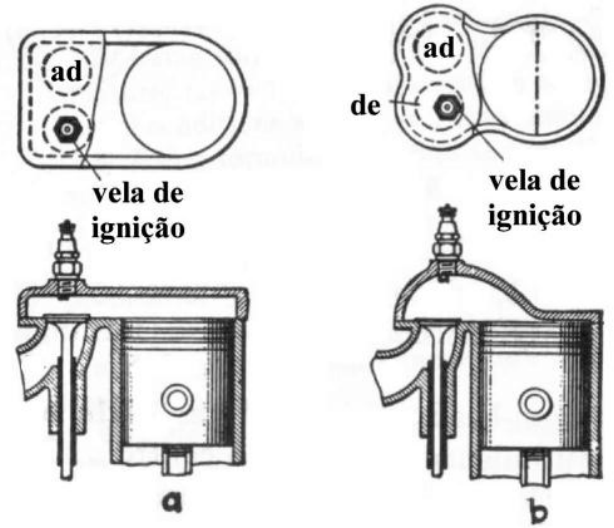

Figura 31 - Câmaras tipo "L" de baixa turbulência (a) e alta turbulência (b) (MALEEV, 1945).

\subsubsection{Câmara Tipo "F"}

Também desenvolvida por Ricardo, esse tipo de câmara é uma evolução da câmara tipo "L". A válvula de descarga se mantém no bloco do motor, enquanto que a válvula de admissão é instalada no cabeçote. Normalmente, a vela de ignição se mantém sobre a válvula de descarga (Figura 32). 
As principais vantagens dessa câmara em relação à anterior são compactação da câmara de combustão e maior diâmetro da válvula de admissão.

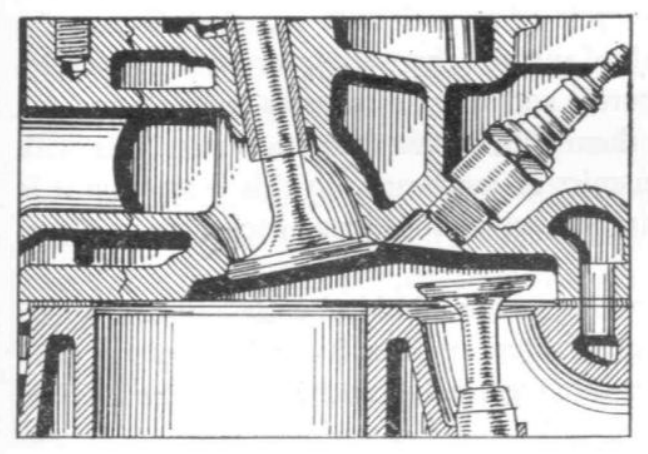

Figura 32 - Câmara tipo "F" (JUDGE, 1965).

\subsubsection{Câmara Tipo Coração}

Nesse tipo de configuração, as válvulas geralmente são planas e em linha, com acentuada área de compressão. As válvulas encontram-se abrigadas na área restrita em forma de coração, sendo a região da vela de ignição mais exposta, permitindo uma indução de mistura sem restrições ao FRH descendente no interior do cilindro.

Ao final do curso de compressão, a mistura é fortemente impelida para a cavidade da câmara de combustão por meio da área de compressão, gerando alta turbulência momentos antes do período de combustão. O nível de turbulência gerado pelo FRH induzido, e pelo FRC, se eleva praticamente de forma proporcional ao aumento de rotação do motor, e consequentemente aumentando a velocidade de queima, mantendo praticamente constante o ângulo de queima.

$\mathrm{Na}$ fase final do processo de exaustão, já com a velocidade de escoamento dos gases queimados relativamente baixa, o ressalto em forma de "nariz" mostrado na Figura 33 acentua essa velocidade no processo de descarga. 
Uma variação desse tipo de câmara é a do Porsche 928, que possui as válvulas inclinadas de um ângulo de $20^{\circ}$ em relação ao eixo do cilindro.
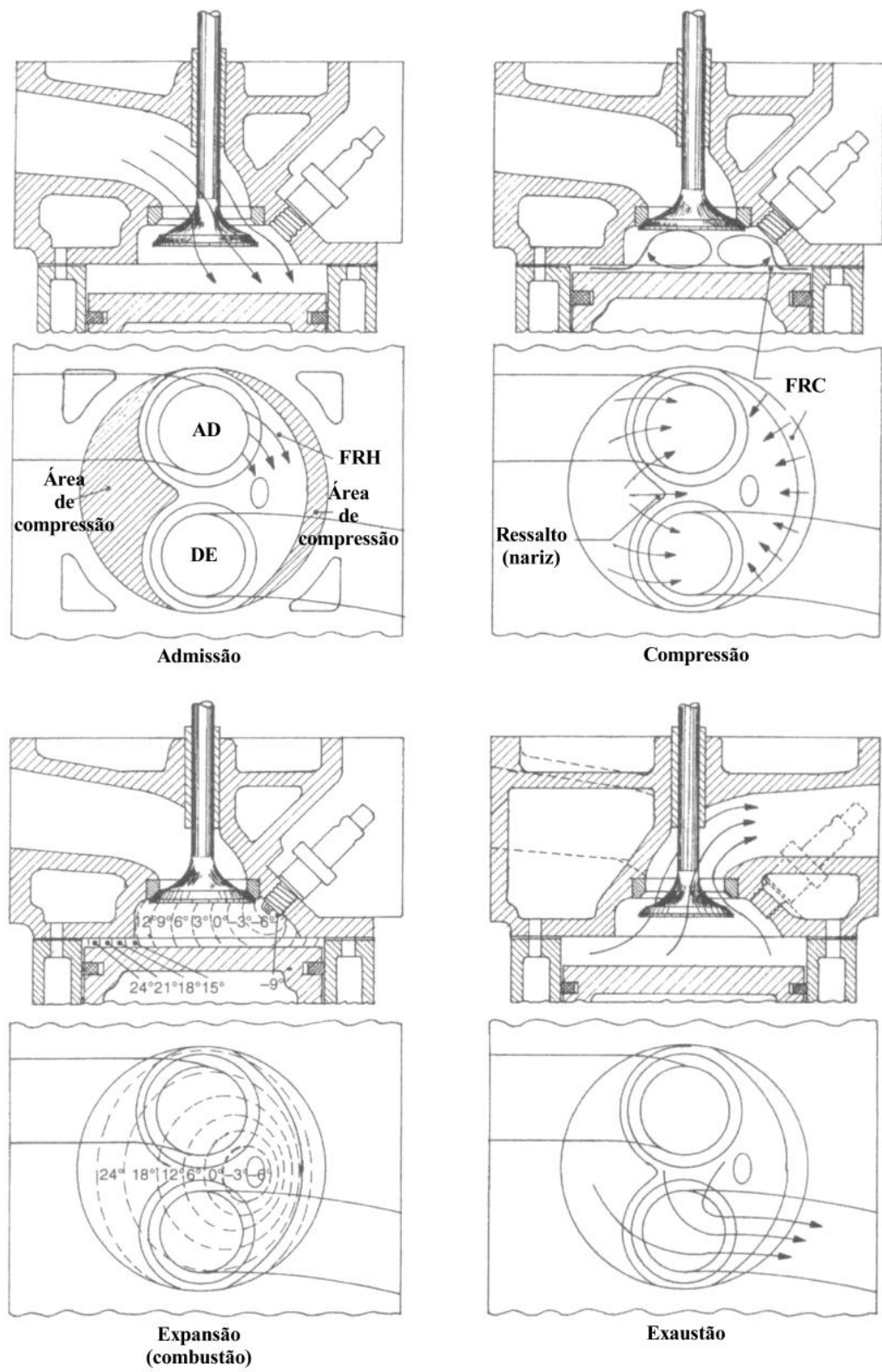

Figura 33 - Câmara em forma de coração (HEISLER, 1995). 


\subsubsection{Câmara Tipo Banheira no Pistão (Cabeçote Plano)}

Nesse tipo de configuração, o cabeçote é do tipo plano, geralmente com uma cavidade circular na cabeça do pistão, e com um duto de admissão de inclinação mais vertical, favorecendo uma indução direta.

Ao final do período de compressão, a área de compressão de contorno circular promove um movimento radial de toda mistura que se encontra próxima da parede do cilindro, concentrando-a nessa cavidade central, em cuja extremidade está a vela de ignição. Como o nível de turbulência é alto nessa configuração, o grau de homogeneidade da mistura também é grande (Figura 34).
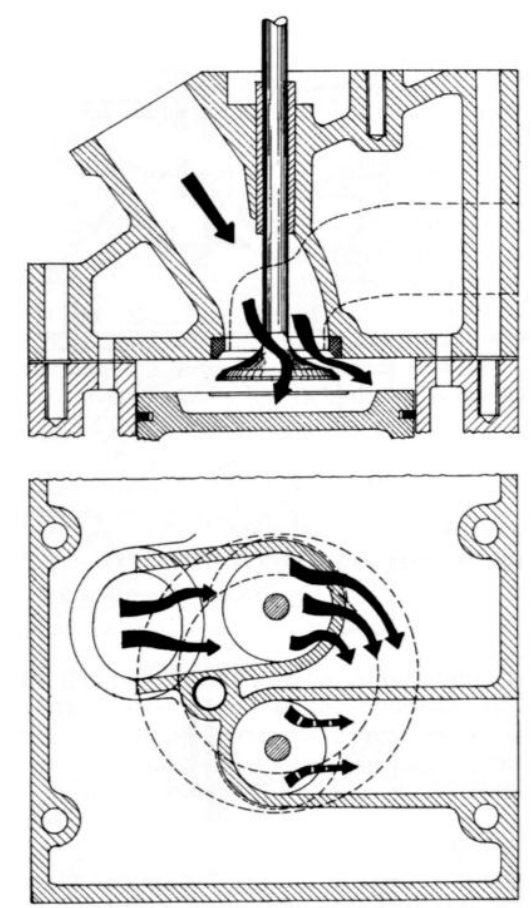

Figura 34 - Câmara tipo banheira no pistão (HEISLER, 1995).

Quando a cavidade circular é no cabeçote e o pistão é plano, costuma-se chamar a câmara de combustão de "câmara tipo banheira invertida (no cabeçote)". A câmara tipo coração é uma variação desse tipo de câmara. 


\subsubsection{Câmara de Combustão Tipo Cunha (Wedge Chamber)}

Essa câmara possui um rebaixo inclinado em forma de cunha no cabeçote, sendo normalmente utilizado um pistão de cabeça plana. As válvulas são acomodadas na face menos inclinada, sendo a vela de ignição localizada na face oposta mais inclinada, e entre as válvulas.

A mistura que entra no cilindro é direcionada a essa face mais inclinada, gerando FRH descendente.

Ao final do curso de compressão, a mistura é fortemente impelida para a região da vela de ignição por meio da área de compressão, e após o disparo da centelha, a frente de chama se propaga por toda a cavidade da câmara de combustão, onde alcançará a sua máxima temperatura. Após penetrar na área de resfriamento onde a relação superfície-volume e o nível de turbulência são altos, a mistura é rapidamente resfriada, podendo até mesmo causar a extinção da chama.

Esse processo tem um efeito positivo quanto à detonação, mas pode aumentar os índices de emissões de hidrocarbonetos (HEISLER, 1995). A Figura 35 mostra uma representação desse tipo de câmara. 


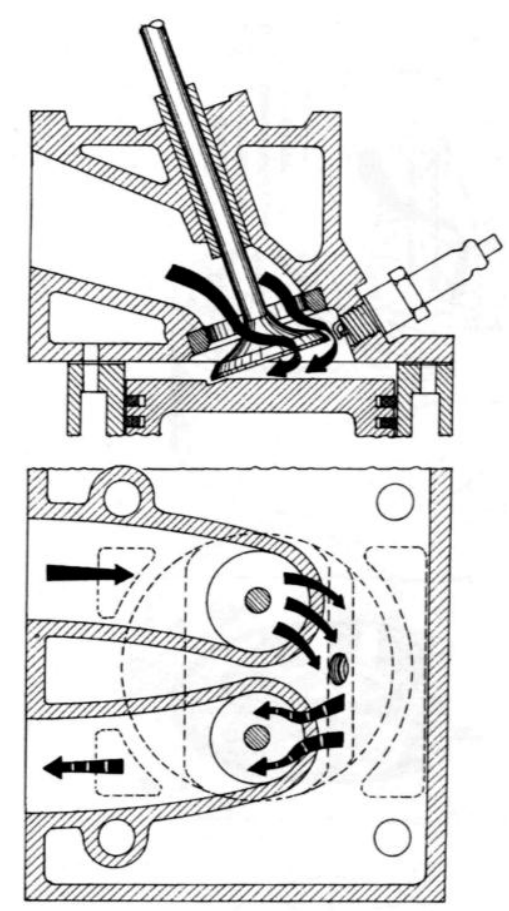

Figura 35 - Câmara de combustão tipo cunha (HEISLER, 1995).

\subsubsection{Câmara de Combustão com Câmara Auxiliar}

Esse tipo de configuração foi apresentado pela Honda em 1975 no motor CVCC (compound vortex controled-combustion), concebido para trabalhar com mistura pobre e homogênea, de modo a produzir baixas emissões de poluentes (Figura 36).

Uma câmara auxiliar, que possuía uma pequena válvula de admissão próxima à vela de ignição, admitia uma mistura mais rica do que a aspirada pela câmara principal. Era necessário um carburador especialmente destinado a fornecer a essa câmara auxiliar uma mistura mais rica, transmitida por meio de uma passagem auxiliar.

No início da fase de admissão, as duas válvulas eram abertas, e era admitida uma mistura bem mais pobre pela válvula da câmara principal do que pela câmara auxiliar. Quando se iniciava a fase de compressão, parte da mistura pobre da câmara principal invadia a câmara auxiliar, tornando a mistura que estava excessivamente rica próxima da vela, em condições ideais para uma boa queima. 
Uma versão mais moderna desse tipo de câmara é a do Porsche SKS (Figura 37), onde o carburador foi substituído por um sistema de injeção mecânica.
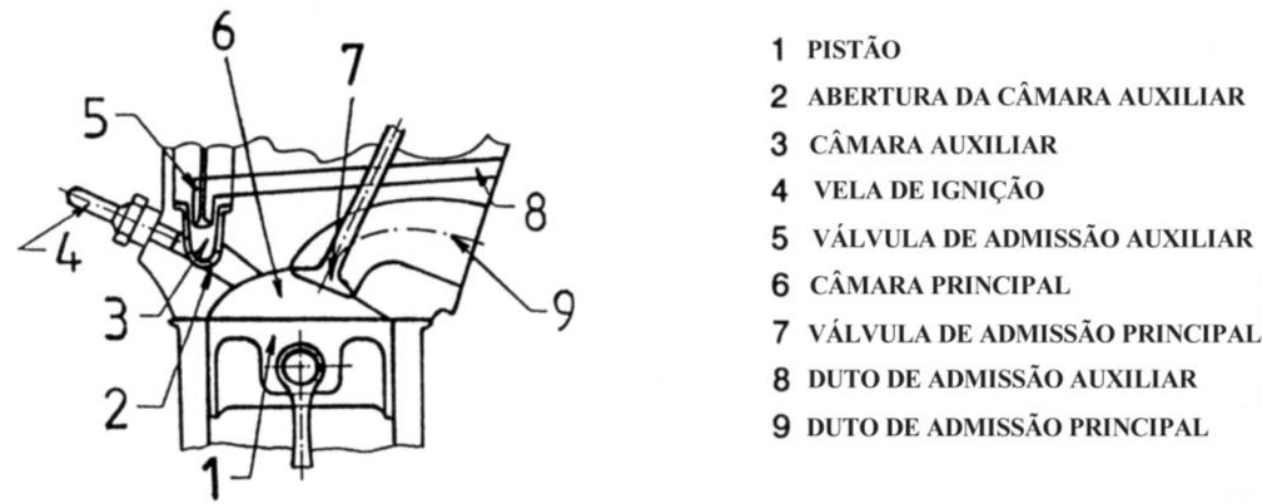

Figura 36 - Câmara de combustão com câmara auxiliar (LENZ, 1992).

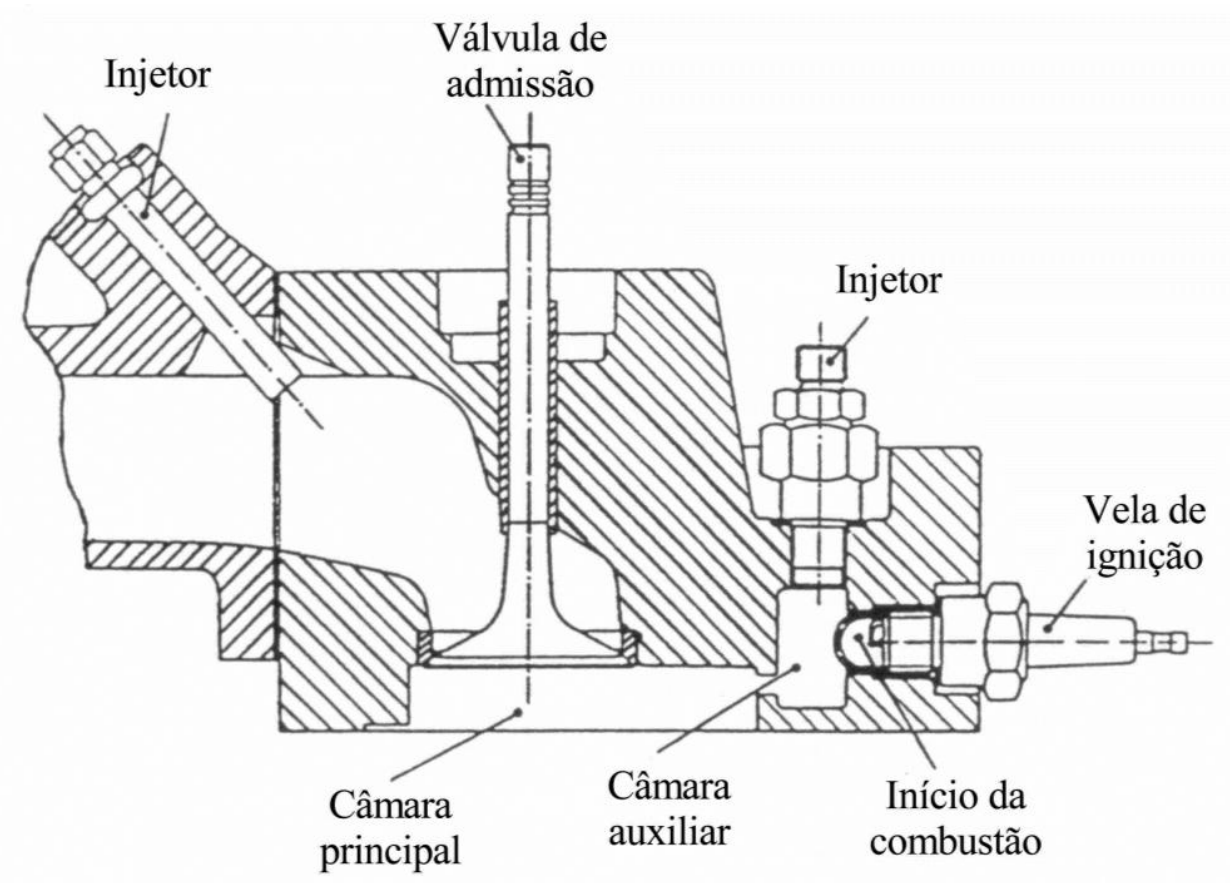

Figura 37 - Câmara do Porsche SKS com injeção mecânica (LENZ, 1992). 


\subsubsection{Câmara de Combustão May Fireball}

Possui esse nome em homenagem a seu criador Michael May. Nesse tipo de câmara de combustão, o pistão é do tipo plano e as válvulas de admissão e descarga são paralelas e verticais. A cavidade da câmara está localizada abaixo das válvulas de admissão e descarga, e a elevação do nível da válvula de descarga em relação à de admissão é extremamente acentuada, como mostra a Figura 38.
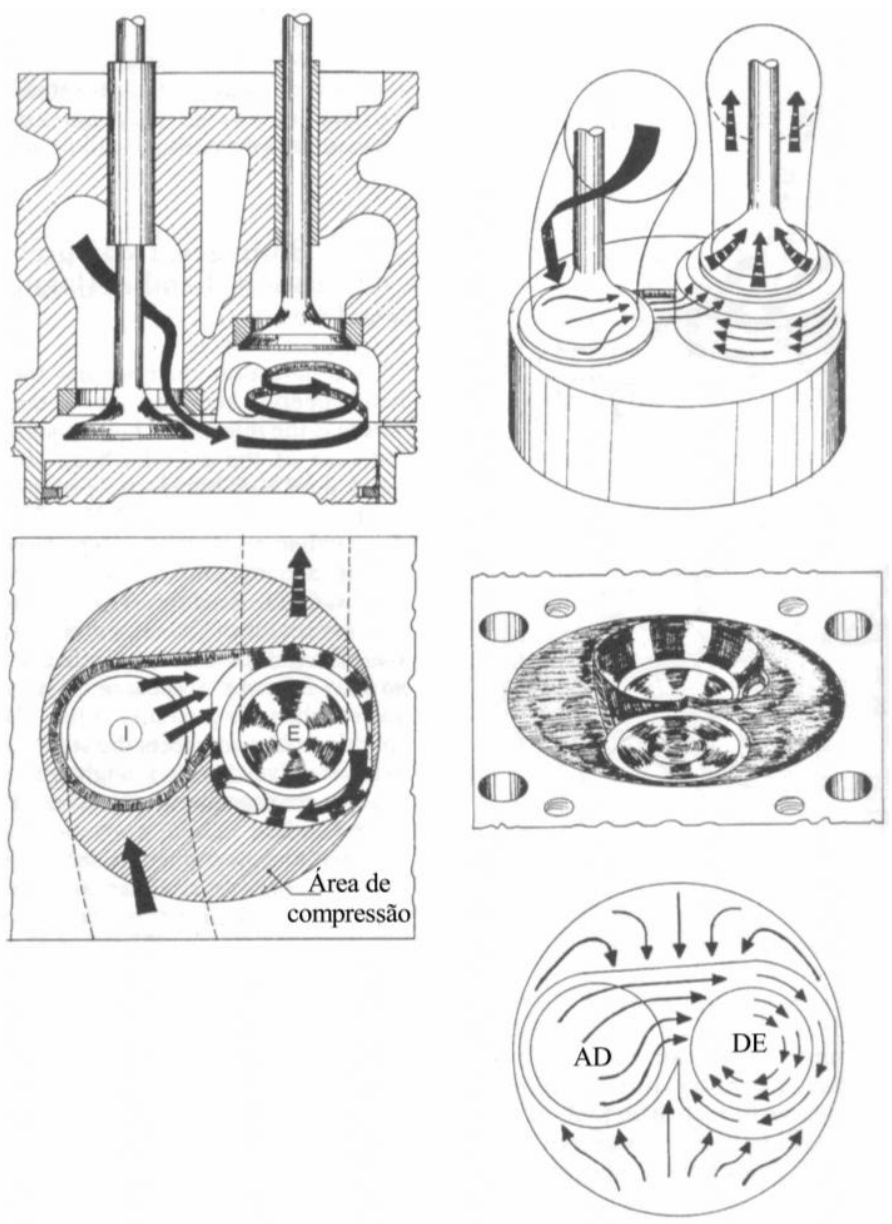

Figura 38 - Câmara de combustão May fireball (HEISLER, 1995).

Toda superfície remanescente compreende a área de compressão, que impele de forma violenta a mistura para o interior da cavidade da câmara. Outro efeito importante é o movimento da mistura da região abaixo da válvula de admissão em direção à região da 
válvula de descarga, que ao passar pelo ressalto em forma de nariz, a restrição entre as válvulas aumenta o nível de FRH na fase de compressão.

Segundo Heisler (1995), esse tipo de configuração pode permitir que um motor utilizando gasolina de 92 octanas trabalhe com uma razão de compressão de 12:1 sem risco de detonação. A Figura 38 ilustra esse tipo de câmara.

\subsubsection{Câmara de Combustão Hemisférica}

Nesse tipo de configuração as válvulas de admissão e descarga encontram-se inclinadas entre si, possibilitando a utilização de válvulas maiores em câmaras compactas, onde normalmente os dutos de admissão e exaustão estão dispostos de forma a garantir uma ótima eficiência volumétrica em altas rotações (cross-flow). A câmara de combustão hemisférica possui uma relação superfície-volume muito baixa, o que diminui as perdas de calor para suas paredes e consequentemente aumenta a eficiência térmica do motor.

Embora esse tipo de construção possibilite a utilização de uma vela de ignição central, a posição da vela de ignição depende de vários fatores como o número de válvulas, criação de área de compressão, etc.

Algumas dessas câmaras utilizam pistões planos, que exigem uma complexidade maior da própria câmara para a criação da área de compressão, enquanto outras utilizam pistões trabalhados para a geração dessa área.

Há uma relação de compromisso entre construção de área de compressão e criação de perfis hemisféricos. Normalmente, quanto mais próximo do perfil hemisférico, menos área de compressão fica disponível para geração de turbulência ao final da fase de compressão. Isto torna necessário alto nível de turbulência gerado pelo FRH no curso de admissão, sendo bastante crítico em baixas rotações, e quanto mais áreas de compressão existirem, maiores serão os níveis de turbulência ao final do curso de compressão, essenciais para regimes de baixas rotações, porém, isso normalmente incrementa a relação superfície / volume, aumentando as perdas de calor durante o processo de combustão. 
As câmaras hemisféricas geralmente podem ter de duas a seis válvulas por cilindro.

Devido às suas variações de forma, elas também poderão ser chamadas, em alguns casos, de câmaras "telhado" (pentroof), quando possuem faces retilíneas que as tornem com aparência de "telhado de duas águas". Embora essa forma não seja realmente hemisférica, é comum encontrá-la classificada como tal em diversas literaturas.

\subsubsection{Câmara Hemisférica de Três Válvulas}

Nesse tipo de câmara normalmente utilizam-se duas válvulas de admissão de mesmo diâmetro acomodadas paralelamente na mesma face, cuja inclinação costuma ser em torno de $20^{\circ}$ em relação à vertical, enquanto que a válvula de descarga, de maior diâmetro, encontra-se solitária na face oposta também inclinada do mesmo ângulo, só que para o lado oposto, formando um ângulo total de $40^{\circ}$ entre as válvulas de admissão e descarga (Figura 39).

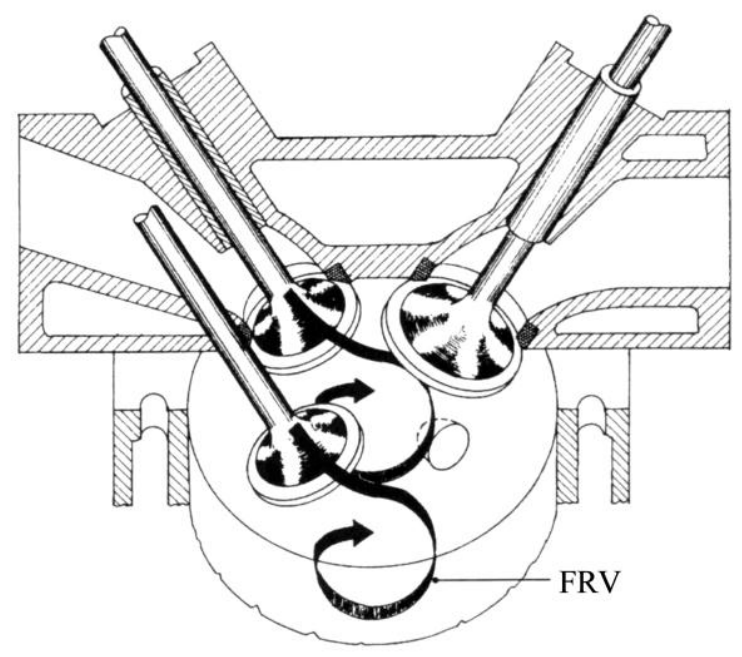

Figura 39 - Câmara hemisférica de três válvulas (HEISLER, 1995).

A vela de ignição é instalada o mais próximo possível do centro da câmara, para que o percurso da chama seja o menor possível, além de proporcionar uma maior área de compressão disponível. 
As duas válvulas de admissão aumentam a capacidade de enchimento do cilindro, diminuindo a necessidade de um cruzamento de válvulas acentuado, minimizando os índices de emissões de poluentes em marcha lenta e em cargas parciais, além de atenuar a inércia de funcionamento de cada válvula (HEISLER, 1995).

\subsubsection{Câmara Hemisférica de Quatro Válvulas}

Utilizada na grande maioria dos motores multiválvulas, esse tipo de configuração mostrase superior à versão de três válvulas por também ser capaz de promover um ótimo esvaziamento do cilindro a altas rotações. Embora a área de compressão seja normalmente pequena quando se utilizam pistões planos, a utilização de pistões de cabeça trabalhada pode incrementar essa área. Em altas rotações, normalmente a eficiência volumétrica é diminuída, porém essa configuração proporciona maior fluxo de entrada, que ocasiona uma menor perda de eficiência volumétrica, e os níveis de turbulência desejáveis podem ser adquiridos pela geração de FRV assistido por FRC (FUJIMOTO et al., 2002).

O FRH, muito importante em baixas rotações, normalmente característico de motores com somente uma válvula de admissão, é comprometido nesse tipo de construção, a menos que se adote uma estratégia de diminuir ou até mesmo de bloquear completamente o fluxo de carga por uma das válvulas (AUTOMOTIVE ENGINEERING, 1987).

Em geral, aumentar o número de válvulas por cilindro melhora o seu enchimento e esvaziamento e eleva as curvas de torque e potência em médias e altas rotações (Figura 40), mas pode não trazer efeitos benéficos em baixas rotações. Isto ocorre devido à diminuição da velocidade de entrada da carga, que faz os níveis de turbulência nesse regime decrescerem, aumentando até mesmo a variação cíclica no regime de marcha lenta e tornando necessários dispositivos auxiliares, como dito anteriormente, capazes de garantir níveis de turbulência ideais (AUTOMOTIVE ENGINEERING, 1987).

A Figura 41 mostra exemplos de câmaras de quatro e cinco válvulas por cilindro. 


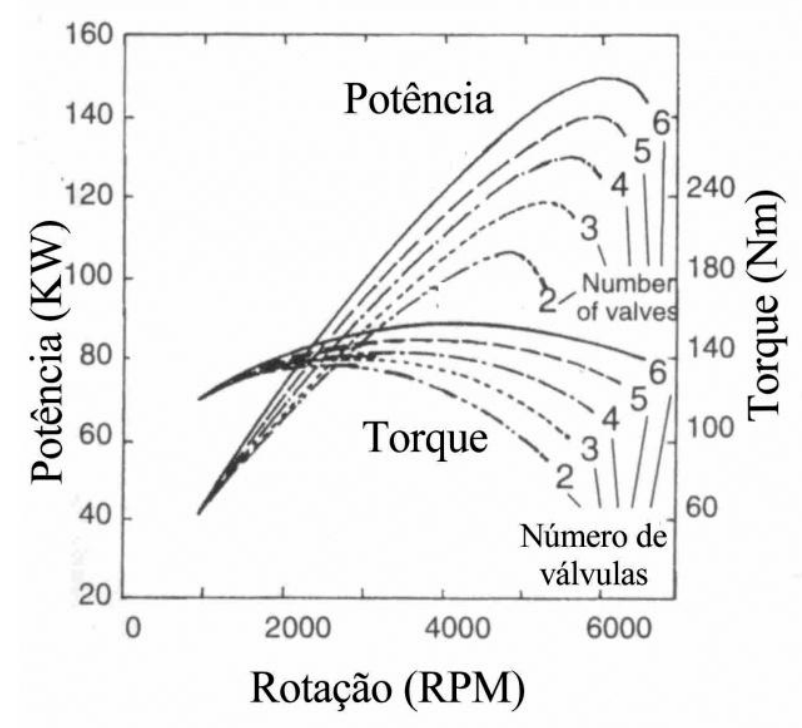

Figura 40 - Efeito do número de válvulas sobre a performance do motor (HEISLER, 1995).
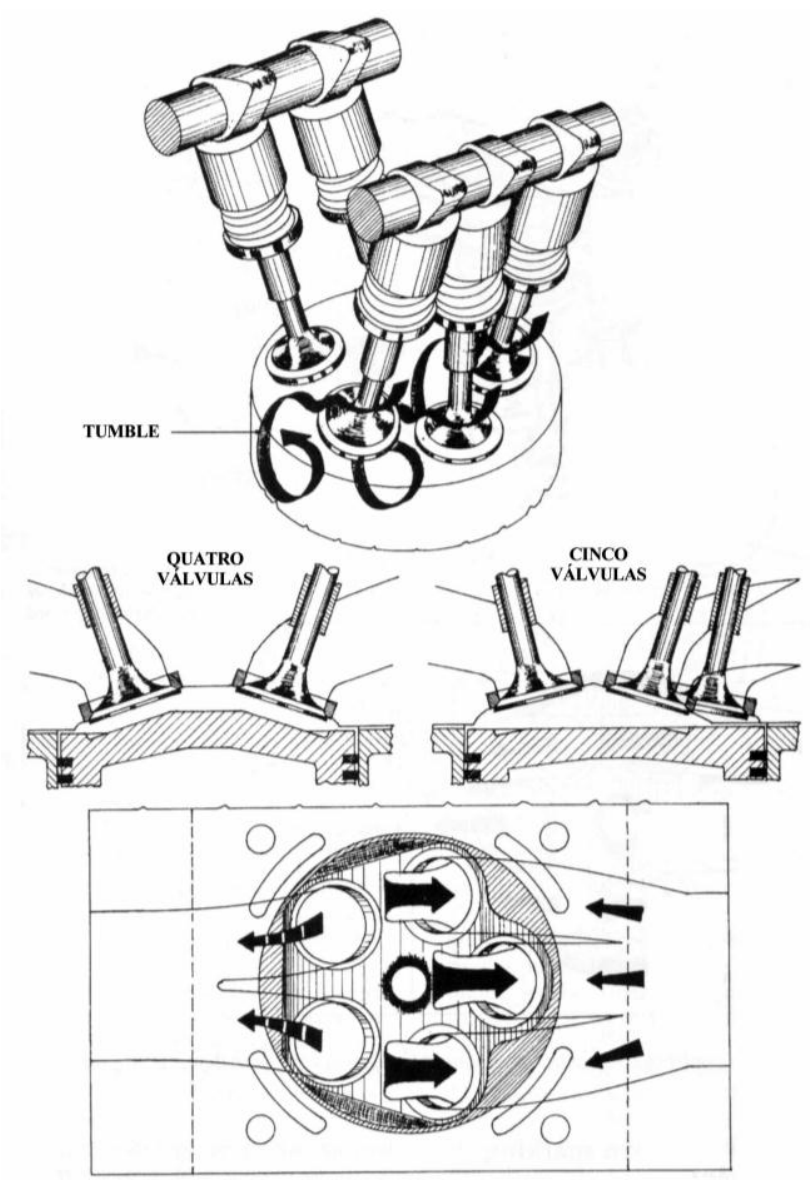

Figura 41 - Câmara hemisférica de quatro e cinco válvulas (HEISLER, 1995). 


\subsubsection{Câmara de Combustão para Motor de Queima Pobre}

Uma característica marcante dos motores de queima pobre é a velocidade da frente de chama relativamente baixa. Para se aumentar essa velocidade as câmaras de combustão desses motores devem gerar altos níveis de turbulência (URUSHIHARA, 1996). Por isso, alguns modelos utilizam câmaras com dutos de admissões helicoidais, para garantir altas taxas de FRH (Figura 6).

Outra saída comum é a utilização de uma vela de ignição tão centralizada quanto possível, onde o percurso da chama é minimizado, ou a utilização de múltiplas velas de ignição para obter o mesmo efeito.

Como já foi dito antes, a posição da vela tem um papel fundamental no controle do tempo de queima na câmara de combustão, mas algo tão importante quanto o tempo de queima é a taxa de elevação de pressão no interior do cilindro em relação ao ângulo de manivela, que pode variar consideravelmente em função da posição e do número de velas de ignição (MARVIN et al., 1936).

Quanto menor for o período de queima, menores serão as perdas devido ao tempo e, dessa forma, maior eficiência será obtida com o menor tempo de combustão. Por outro lado, quanto menor o tempo de combustão, maior será a taxa de elevação de pressão no cilindro, exigindo mais da estrutura do motor (MARVIN et al., 1936).

Atualmente, costumam-se utilizar duas velas de ignição em motores de queima pobre, devido à menor velocidade de propagação da chama no interior da câmara de combustão. Dessa forma, pode-se reduzir o período de queima nesses motores.

Heisler (1995) mostrou uma configuração atual de duas velas de ignição para motor de queima pobre (Figura 42). Percebeu-se que para o caso (a), a centelha foi disparada a $12^{\circ}$ APMS e a combustão completa se deu até $24^{\circ}$ DPMS, totalizando $32^{\circ}$ do eixo de manivela. No caso (b), o disparo da centelha se deu a $8^{\circ}$ APMS e a combustão completa se deu até $18^{\circ}$ 
DPMS, totalizando $26^{\circ}$ do eixo de manivela. Esse menor período de queima tem efeitos positivos, como já foi mencionado antes. Segundo o autor, dupla ignição:

- Sob condições favoráveis, permite que a relação ar-combustível da mistura varie entre 17:1 a 21:1 em cargas parciais, mas não traz nenhum benefício à plena carga, onde a mistura é consideravelmente rica;

- Diminui a variação cíclica de pressão no interior do cilindro, melhorando o funcionamento do motor em marcha lenta e em cargas parciais;

- Permite que o motor possa operar com cruzamento de válvulas relativamente alto, sob condições de marcha lenta e válvula borboleta parcialmente aberta, sem o aumento de emissões de poluentes;

- Desenvolve maior torque em baixas rotações, mas não tem efeito significativo em altas rotações;

- Tende a melhorar o consumo de combustível em condições de cargas parciais;

- Capacita o motor a operar com um avanço da centelha menor, melhorando sua qualidade de funcionamento;

- Permite usar maior recirculação de gases do escapamento, melhorando os índices de emissões de poluentes; 

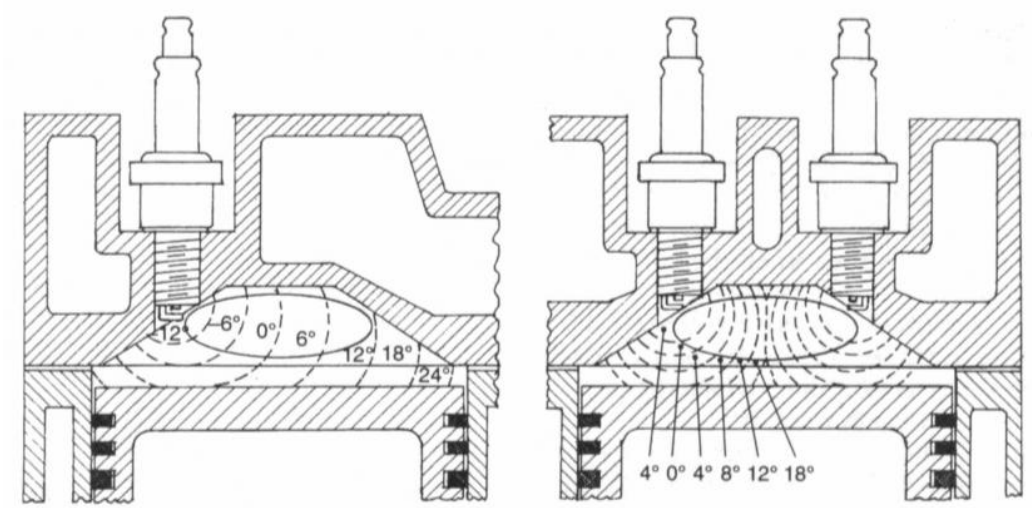

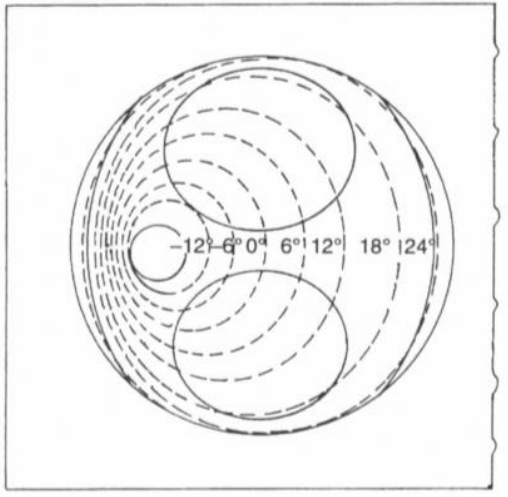

(a) ignição simples

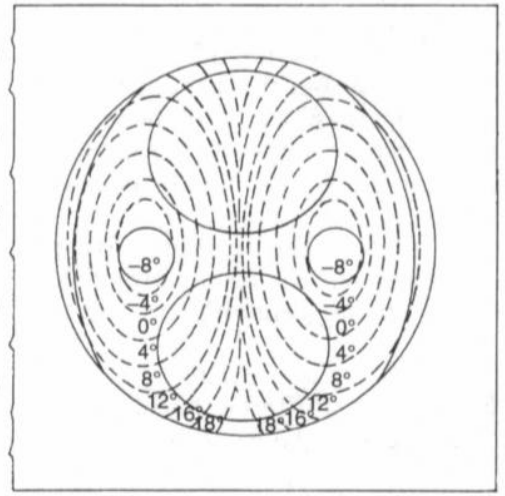

(b) dupla ignição

Figura 42 - Câmara com duas velas de ignição (HEISLER, 1995).

\subsection{CÂMARA DE COMBUSTÃO PARA MOTOR ASSISTIDO POR INJEÇÃO DIRETA DE COMBUSTÍVEL}

O desenvolvimento de motores do ciclo Otto assistidos por injeção direta de combustível no interior da câmara de combustão tem sido motivado pela busca de motores de baixo consumo de combustível, que sejam mais eficientes nos regimes transitórios e na partida a frio, e de baixos índices de emissões de poluentes. O processo de injeção, a vaporização e atomização do jato de combustível, as trocas de calor da carga com as paredes da câmara de combustão e topo do pistão, a preparação da mistura e controle do movimento do fluxo de ar na câmara, são itens de grande importância para tais motores.

A maior diferença entre o motor de injeção direta de combustível (GDI) e o motor de injeção na válvula de admissão (PFI) está na estratégia de formação de mistura. No sistema 
PFI, o combustível é injetado antes da válvula de admissão, com a mesma aberta ou fechada, dependendo do regime de funcionamento. Na maioria dos casos essa injeção se dá com a válvula fechada com o motor aquecido e em regime permanente, e com a válvula aberta nas condições de mudança de regime, partida a frio, aquecimento e solicitação de potência. $\mathrm{O}$ diâmetro médio das gotas imediatamente após injeção é cerca de 16 mícrons para o sistema GDI, contra cerca de 120 mícrons do PFI. No sistema GDI o combustível é injetado diretamente na câmara de combustão, podendo operar com mistura homogênea ou carga estratificada, em função do momento de injeção de combustível.

Durante a partida do motor, com o sistema PFI, são necessários cerca de 10 ciclos para que o motor entre em funcionamento, devido ao filme de líquido que está se formando no duto de admissão, enquanto que no sistema GDI bastam apenas cerca de dois ciclos, como relatam Zhao et al. (1999). Eles também descrevem algumas vantagens do sistema GDI, como:

- Melhora do consumo de combustível;

- Menor perda de carga;

- Utilização de maior taxa de compressão, por consequência do resfriamento da carga durante a injeção;

- Maior eficiência volumétrica;

- Melhor resposta transitória, exigindo menos enriquecimento na aceleração, devido a não condensação do combustível no coletor;

- Controle mais preciso da relação ar-combustível;

- Menor emissão de hidrocarbonetos na partida a frio;

- Menor emissão de dióxido de carbono;

Embora o sistema GDI possua inúmeras vantagens sobre o PFI, existem várias limitações tecnológicas para a sua efetiva utilização, como citadas por Zhao et al. (1999): 
- Dificuldade no controle da estratificação de carga e combustão na faixa de operação requerida;

- Complexidade tecnológica para o controle da injeção em diferentes condições de carga e estratégia;

- Taxa de formação de depósitos relativamente alta no injetor dos motores a gasolina;

- Emissões de hidrocarbonetos relativamente altas em condições de baixas cargas;

- Emissões de $\mathrm{NO}_{\mathrm{X}}$ relativamente alta em condições de altas cargas;

- Alta produção de $\mathrm{NO}_{\mathrm{X}}$ sob cargas parciais na condição de injeção com carga estratificada;

- Condições de operação incompatíveis com o uso de catalisadores;

- Necessidade de componentes do sistema de injeção que resistam à alta pressão e baixa lubricidade do combustível.

Esses dados se referem à utilização de gasolina como combustível sob diversas condições de operação, pois na medida em que esforços são feitos para que os motores atuais operem em condições de misturas muito pobres, as altas emissões de $\mathrm{NO}_{\mathrm{X}}$ citadas acima podem ser reduzidas. Embora não seja possível reduzir os índices de $\mathrm{NO}_{\mathrm{X}}$ em cerca de $90 \%$ como eventualmente fazem os catalisadores atuais, pesquisas recentes apontam para a possibilidade do desenvolvimento de catalisadores de $\mathrm{NO}_{\mathrm{X}}$ que operem de forma eficiente com misturas pobres.

\subsubsection{Requisitos do Sistema de Injeção GDI}

Um sistema de injeção direta de combustível para motor de ignição por centelha deve ser capaz de promover injeção tardia de combustível, ao final do período de compressão, para a operação com carga estratificada normalmente obtida em condições de cargas parciais, e 
injeção antecipada, ainda durante o período de admissão, para a formação de mistura homogênea requerida em plena carga (STAN et al., 2001); (WYSZYNSKI et al., 2002).

Sob cargas parciais, é desejável um jato compacto capaz de promover uma rápida formação de mistura e controlar a estratificação, enquanto que em plena carga é desejável um jato bem disperso, para garantir a homogeneidade da mistura. A pressão de injeção também deve poder variar em função da estratégia (STAN, 2001).

Nota-se que as duas condições de formação do jato não parecem ser algo fácil para uma única válvula de injeção, por isso algumas montadoras adotam apenas uma estratégia de funcionamento, por motivo de simplicidade (ZHAO et al., 1999).

A utilização de válvulas injetoras com características intermediárias, auxiliadas por sistemas de variação de pressão de injeção, também tem sido feita.

Pequenas variações no ângulo de injeção podem alterar de forma significativa a performance do motor GDI (STAN, 2001).

O tipo de combustível utilizado também tem efeito na qualidade da injeção. Como reportado por Stan et al. (2001), a qualidade do jato de combustível injetado no interior da câmara de combustão é maior para o etanol do que para a gasolina, quando em mesma condição de operação do motor e com o volume de injeção calibrado para se obter mistura estequiométrica.

\subsubsection{Geometria da Câmara de Combustão}

A geometria da câmara de combustão precisa ter um forte vínculo com a estratégia de formação de mistura e do processo de combustão. Para os motores de ignição por centelha que queimam uma mistura homogênea, é desejável a geração de altos níveis de turbulência (difusiva) da mistura no interior da câmara de combustão, e de baixa velocidade da carga (convectiva) na região da vela de ignição. Isso normalmente é realizado por motores de injeção PFI e GDI que operam exclusivamente com injeção antecipada. Entretanto, para os 
motores GDI que trabalham com injeção tardia é desejável alta velocidade do fluxo (convectivo), e baixos níveis de turbulência (difusiva), que auxiliam numa estratificação mais estável (ZHAO et al., 1999).

A geração de FRH (swirl), FRV (tumble) e FRC (squish) são recursos utilizados por todos os motores de combustão interna, que dependem fortemente da geometria da câmara de combustão. Estes recursos são empregados em função da estratégia de formação de mistura e de combustão de cada motor em questão.

Uma câmara de combustão para um motor assistido por injeção direta de combustível deve ser capaz de proporcionar a melhor localização e orientação do injetor de combustível relativamente à vela de ignição, pois na condição de carga estratificada o momento da injeção e sua duração devem manter um vínculo com o momento do disparo da centelha. Deve-se considerar uma relação de compromisso entre o momento de injeção e ignição, pois avançar a centelha e retardar a injeção pode ser conflitante, devido ao tempo necessário para a atomização da mistura. $\mathrm{O}$ injetor deve ser posicionado de forma a garantir uma estratificação de carga estável sob cargas leves e utilizar, de maneira proveitosa, o fluxo de ar da admissão para a formação de uma mistura homogênea em cargas elevadas (injeção antecipada). Os diâmetros das válvulas de admissão e descarga podem vir a ser penalizados por tais requisitos.

Um exemplo de câmara de combustão utilizada na primeira geração de motores GDI, é a do motor Benz 300SL de 1954 ilustrada na Figura 43. Essa câmara possuía uma região de confinamento da mistura próxima da vela de ignição, porém esse motor não utilizava a estratégia de estratificação de carga, pois ele trabalhava apenas com injeção antecipada, ou seja, mistura homogênea. Seu sistema de injeção mecânica trazia limitações de estratégia, pois uma vez que a injeção tardia requer um sistema de controle mais fino do momento e duração da injeção de combustível (ZHAO et al., 1999). 


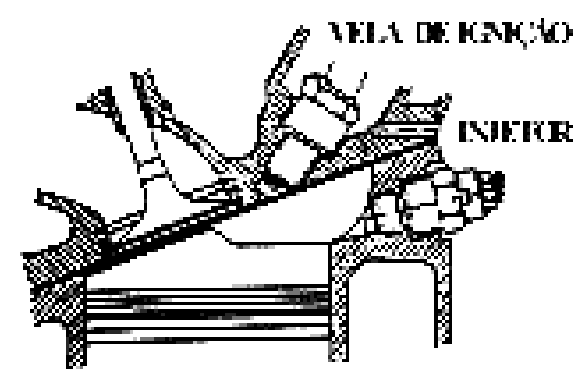

Figura 43- Motor Benz 300 SL (ZHAO et al., 1999).

No período compreendido entre os anos de 1960 e 1979, diversos motores GDI foram propostos a fim de explorar seu grande potencial. Motores como: MAN-FM, Texaco TCCS e Ford PROCO possuíam a câmara de combustão na cabeça do pistão, sendo os dois primeiros caracterizados pela estratégia única de carga estratificada, gerada através da interação do jato de combustível com a parede interna da câmara no pistão e auxiliada pela rotação do ar (FRH) em seu interior. Essa estratégia permitia baixo consumo em cargas parciais, porém era ineficiente em transições de regimes e em plena carga. O terceiro possuía injeção centralizada com dupla vela de ignição, possibilitando um maior atraso do momento da ignição, porém, também não se mostrava eficiente em plena carga (ZHAO et al., 1999).

Atualmente, com o auxílio de sistemas de gerenciamentos eletrônicos sofisticados, podese modificar a estratégia de alimentação e ignição, em função das condições de operação do motor. Quanto mais versátil for o sistema, maior o custo de implementação, o que faz com que, ainda hoje, alguns sistemas de injeção direta sejam muito limitados. De modo geral, os sistemas mais modernos integram quatro estratégias básicas de operações: injeção antecipada (homogênea) estequiométrica para partida a frio, transitórios e cargas elevadas; injeção antecipada pobre em cargas parciais "médias" para menores consumos e emissões; injeção 
tardia (carga estratificada) pobre em marcha lenta e cargas leves para máxima economia de combustível.

\subsubsection{Estratégias Básicas para Formação da Mistura}

As câmaras de combustão, normalmente são projetadas em função das estratégias de alimentação e formação de mistura. Itens como posicionamento da vela de ignição e injetor, tipo de jato, dimensão e localização da área de compressão, associada ao tipo de movimentação da carga no interior da câmara (FRH ou FRV), basicamente definem a forma da câmara de combustão. A Figura 44 mostra quatro estratégias básicas de formação de mistura e as formas das câmaras de combustão de sistemas GDI utilizadas para as mesmas:

(a)
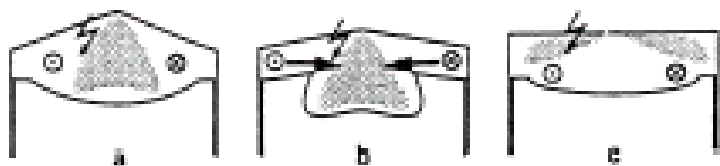

(b)
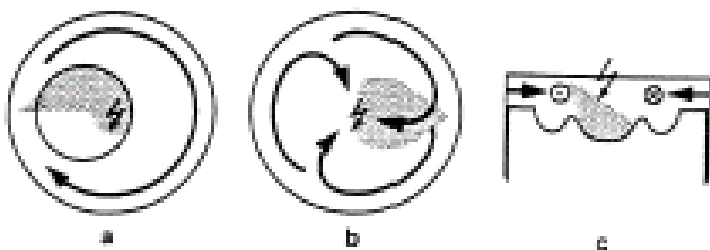

(c)
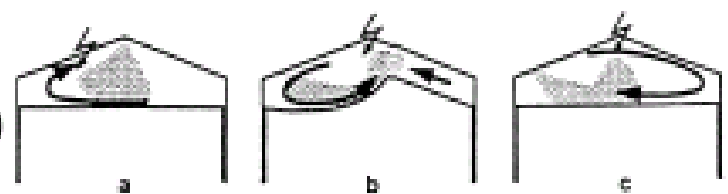

(d)
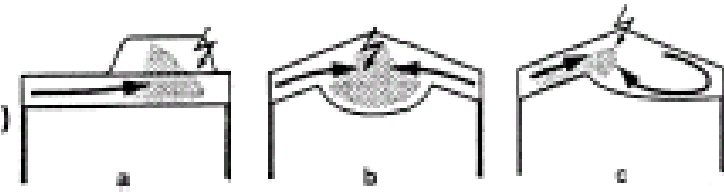

Figura 44 - Câmaras de combustão GDI (ZHAO et al., 1999).

- (a): sistemas com injeções centrais assistidos por FRH, normalmente utilizados em câmaras abertas $(a)$ ou em câmaras na cabeça do pistão $(b, c)$; 
- (b): sistemas com velas de ignição centrais e injetores laterais, também assistidos por FRH, mais comumente utilizados com câmaras excêntricas no pistão $(a)$;

- (c): sistemas assistidos por FRV $(a, b, c)$, normalmente utilizados para estratégia de injeção tardia, em particular, esse tipo de movimento de carga é fortemente intensificado quando associado ao FRC (b) no final da fase de compressão;

- (d): sistemas assistidos por FRC, para geração de altos níveis de turbulência;

Zhao et al.(1999) reportam, como resultado da aceleração rotacional da carga durante a compressão, que o FRV pode ser eficaz na preparação da mistura em caso de injeção tardia, sendo amplamente aplicado em motores GDI. Eles mostram um sistema desenvolvido por engenheiros da Mitsubishi e Ricardo que adota o conceito de "fluxo rotacional vertical reverso" (FRVR), como ilustrado na Figura 45.

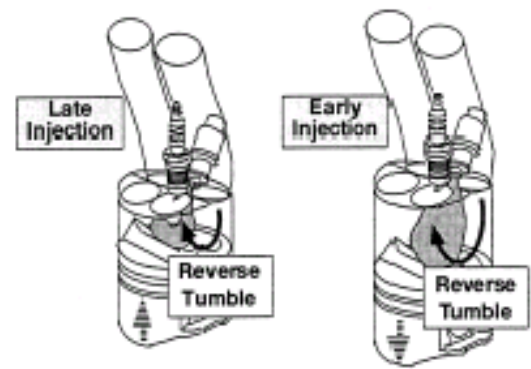

(a)

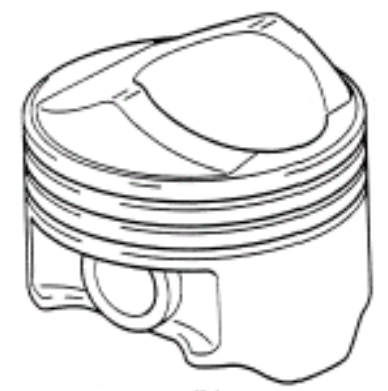

(b)

Figura 45 - Fluxo Rotacional Vertical Reverso (reverse tumble) (ZHAO et.al., 1999).

Esse tipo de movimento é gerado pela posição praticamente vertical do duto de admissão, direcionando o fluxo de ar para a cavidade do pistão, de forma a gerar rotação favorável ao jato de combustível que deve ser acelerado em direção à vela de ignição. 


\subsection{RESUMO DOS REQUISITOS DE UMA CÂMARA DE COMBUSTÃO PARA MOTORES ICE}

Com base nas informações anteriores, pode-se concluir que os principais requisitos de uma câmara de combustão para motor do ciclo Otto deve:

- Possuir a menor relação superfície / volume possível, para minimizar as perdas de calor para as regiões frias que prejudicam a combustão;

- Proporcionar o menor percurso da chama possível, para minimizar o período de queima, aumentando a taxa de elevação de pressão, além de seu valor de pico;

- Possuir áreas de compressões e resfriamentos com dimensões capazes de, além de gerar altos níveis de turbulência, evitar o superaquecimento da mistura na região de detonação (end-gas), prevenindo do fenômeno de detonação, porém, tomandose cuidado para não exceder o limite de emissões de hidrocarbonetos.

- Possuir a vela de ignição localizada o mais próximo possível da válvula de escape, a fim de garantir à mistura uma temperatura ideal para a queima, sendo o grau térmico da vela ajustado para que a mesma não seja um "ponto quente", o que provoca a pré-ignição. Consequentemente essa estratégia também faz com que a válvula de escape não esteja próxima da região de detonação;

- Ser capaz de gerar níveis de turbulência adequados para promover uma rápida homogeneização da mistura, atingir taxas de queima e elevações de pressões ideais, sem gerar excessiva perda de calor e sem sobrecarregar mecanicamente o motor;

- Garantir que a temperatura da válvula de escape se encontre em condições ideais de funcionamento, sem gerar autoignição; 
- Possuir a máxima razão de compressão possível para uma maior eficiência térmica, sem gerar detonação ou mesmo sacrificar as partes mecânicas do motor por esforço excessivo (severidade);

- Promover a entrada de mistura fresca e a saída de gases queimados com a menor restrição possível, sob quaisquer condições de funcionamento. 


\section{MODELAMENTO 1D}

Este trabalho apresenta duas propostas de modelamentos de combustão para motor de ignição por centelha. A primeira analisa a quentão de maneira fenomenológica, sem levar em conta características tridimensionais de escoamentos turbilhonares, por exemplo. A segunda aborda o problema tridimensional aplicado à combustão pré-misturada. Para ambos os casos é feita uma comparação com dados experimentais para a validação dos mesmos.

\subsection{MODELO 1D DE DUAS ZONAS E GRANDEZAS ENVOLVIDAS}

No modelo 1D, é adotado o modelo de duas zonas, onde a mistura ar-combustível é considerada homogênea no interior do cilindro, havendo transferência de entalpia da zona não queimada para a zona queimada, resultante da energia química contida no combustível.

\subsubsection{Taxa de Queima (Heat Release)}

É definida como sendo a taxa instantânea de consumo de combustível no processo de combustão. No caso, em questão, esta é a taxa em que as moléculas da mistura são transferidas da zona não queimada para a zona queimada, ocorrendo o processo de reação química, não necessariamente de todas as espécies envolvidas.

\subsubsection{Taxa de Liberação de Calor (Heat Release Rate)}

Comumente definido como sendo a taxa instantânea de conversão de energia química contida nas moléculas de combustível em energia térmica no interior da câmara de combustão. 
Durante o processo de reação, pode ocorrer a formação de produtos intermediários antes da combustão completa, provocando uma diferença momentânea entre a "taxa de liberação de calor" e a "taxa de queima" calculada.

\subsubsection{Taxa de Liberação de Calor Aparente (Apparent Heat Release Rate)}

A taxa de liberação de energia térmica instantânea é calculada com base na medida de pressão do cilindro. A taxa de liberação de calor atual é impossível de se medir por métodos convencionais, pelo fato de não se poder determinar a composição química instantânea no interior do cilindro durante o processo de combustão. Entretanto, a taxa de liberação de calor deve ser inferida da medida de pressão no cilindro, fazendo-se hipóteses simplificadoras.

\subsubsection{Taxa de Queima Aparente (Apparent Burn Rate)}

Este será o termo usado para fazer referência à taxa de queima imposta em uma simulação de combustão não preditiva, a fim de reproduzir a curva de pressão no cilindro.

\subsubsection{Combustão Preditiva (Predictive Combustion)}

Modelo de combustão onde a taxa de queima é predita a partir de dados apropriados (inputs), como: pressão, temperatura, relação ar-combustível, fração residual da combustão anterior (ciclo), etc.

\subsubsection{Combustão Não-Preditiva (Non-Predictive Combustion)}

Modelo de combustão onde a taxa de queima é diretamente imposta como um dado de simulação (input). Com esse modelo, a taxa de queima não depende de variáveis como fração de gás residual ou pressão no cilindro, mas apenas as quantidades de reagentes (ar e combustível) suprirão a queima em uma taxa prescrita. 


\subsubsection{Descrição do Método de Combustão por Duas Zonas}

Método utilizado neste trabalho (1D)

Seja para motor do ciclo Otto ou do ciclo Diesel, o início da combustão é dividido em duas zonas: zona de gases não queimados e queimados. Todo o conteúdo do cilindro se inicia na zona não queimada, incluindo uma fração de gás residual aprisionada a partir do ciclo anterior ou mesmo proveniente da recirculação de gases queimados do escapamento (EGR).

A cada "time step", a mistura ar-combustível é transferida da zona não queimada para a queimada. A quantidade transferida na unidade de tempo define a taxa de queima (burn rate). Nesse processo, aplica-se cálculo de equilíbrio químico para todas as espécies envolvidas, tendo: $\mathrm{C}, \mathrm{H}, \mathrm{O}, \mathrm{N}$ presentes na zona não queimada e $\mathrm{N}_{2}, \mathrm{O}_{2}, \mathrm{H}_{2} \mathrm{O}, \mathrm{CO}_{2}, \mathrm{CO}, \mathrm{H}_{2}, \mathrm{~N}, \mathrm{O}, \mathrm{H}, \mathrm{NO}$, $\mathrm{OH}$ para os produtos na zona queimada. Esse processo é extremamente dependente da temperatura e, em menor grau, da pressão envolvida.

Uma vez que uma nova composição da zona queimada é obtida, a energia interna de cada espécie é calculada. Assim, a energia interna total da zona queimada é obtida somando-se todas as energias internas de cada espécie. Pelo princípio da conservação da energia, as novas temperaturas e pressões das zonas são encontradas.

As equações de conservação de energia são resolvidas separadamente para cada "time step" em cada zona:

\subsubsection{Zona queimada:}

Zona não Queimada:

$$
\frac{d\left(m_{u} e_{u}\right)}{d t}=-p \frac{d V_{u}}{d t}-Q_{u}-\left(\frac{d m_{f}}{d t} h_{f}+\frac{d m_{a}}{d t} h_{a}\right)+\frac{d m_{f, i}}{d t} h_{f, i}
$$

Onde:

$m_{u}=$ massa na zona não queimada; 


$$
\begin{aligned}
& m_{f}=\text { massa de combustível; } \\
& m_{a}=\text { massa de ar; } \\
& m_{f, i}=\text { massa de combustível injetada; } \\
& e_{u}=\text { energia na zona não queimada; } \\
& p=\text { pressão no cilindro; } \\
& V_{u}=\text { volume da zona não queimada; } \\
& Q_{u}=\text { transferência de calor na zona não queimada; } \\
& h_{f}=\text { entalpia da massa de combustível; } \\
& h_{a}=\text { entalpia da massa de ar; } \\
& h_{f, i}=\text { entalpia da massa de combustível injetada; }
\end{aligned}
$$

Zona Queimada:

$$
\frac{d\left(m_{b} e_{b}\right)}{d t}=-p \frac{d V_{b}}{d t}-Q_{b}-\left(\frac{d m_{f}}{d t} h_{f}+\frac{d m_{a}}{d t} h_{a}\right)
$$

Onde:

O sub índice "b" denota zona queimada.

$\mathrm{Na}$ equação de energia para a zona queimada há quatro termos do lado direito que dizem respeito a trabalho de pressão, transferência de calor, combustão e adição de entalpia proveniente do combustível, respectivamente. O terceiro termo (combustão) contém a taxa instantânea de consumo de combustível ou "burn rate" $\left(\mathrm{dm}_{\mathrm{f}} / \mathrm{dt}\right)$ 


\subsubsection{Modelo de Wiebe (Spark-Ignition Wiebe Model)}

Modelo não preditivo utilizado para motores de ignição por centelha pelo qual se impõe a taxa de queima usando a função Wiebe que representa, com boa aproximação, as características da curva de taxa de queima dos motores típicos.

A equação de Wiebe é dada abaixo:

Dados de entrada:

$\mathrm{AA}=$ Ângulo de ancoramento (Anchor Angle);

$\mathrm{D}=$ Duração;

$\mathrm{E}=$ Expoente da "Wiebe";

$\mathrm{CE}=$ Eficiência da combustão (Fração de combustível queimada);

$\mathrm{BM}=$ Percentual de combustível queimado no ângulo de ancoramento (50\%);

$\mathrm{BS}=10 \%$ de massa de combustível queimada;

$\mathrm{BE}=90 \%$ de massa de combustível queimada;

$\mathrm{BMC}=-\ln (1-\mathrm{BM})$

$\mathrm{BSC}=-\ln (1-\mathrm{BS})$

$\mathrm{BEC}=-\ln (1-\mathrm{BE})$

$\mathrm{WC}=$ Constante de "Wiebe";

SOC = Ângulo de início da combustão;

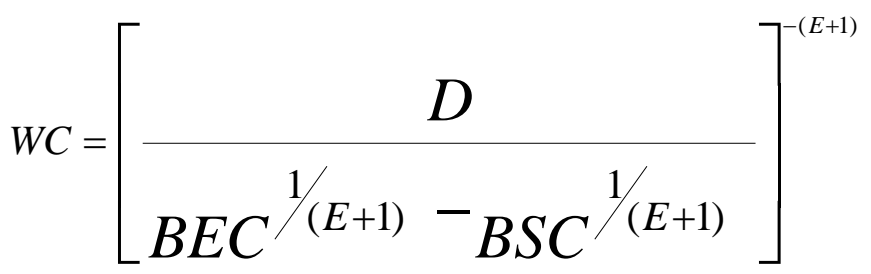




$$
S O C=A A-\frac{(D)(B M C)^{1 /(E+1)}}{B E C^{1 /(E+1)}-B S C^{1 /(E+1)}}
$$

\subsubsection{Cálculo da Taxa de Queima}

A taxa de queima acumulada é calculada normalizando-a para 1. A combustão começa em $0(0 \%)$ e termina em $1(100 \%)$.

$$
\operatorname{Combustão}(\theta)=(C E)\left[1-e^{-(W C)(\theta-S O C)}(E+1)\right]
$$

Existem outros modelos de Wiebe mais complexos, que são mais representativos para injeção direta de combustível, mas nesse trabalho, considera-se apenas a combustão de uma mistura previamente homogeneizada, sendo bem representada pela Wiebe acima.

Abaixo, têm-se análises comparativas entre a taxa de queima calculada pela Wiebe e a taxa experimental, sendo o primeiro quadro ilustrativo (Figura 46) da queima acumulada referente à equação (10), e mais abaixo (Figura 47) ligado à taxa de queima instantânea:

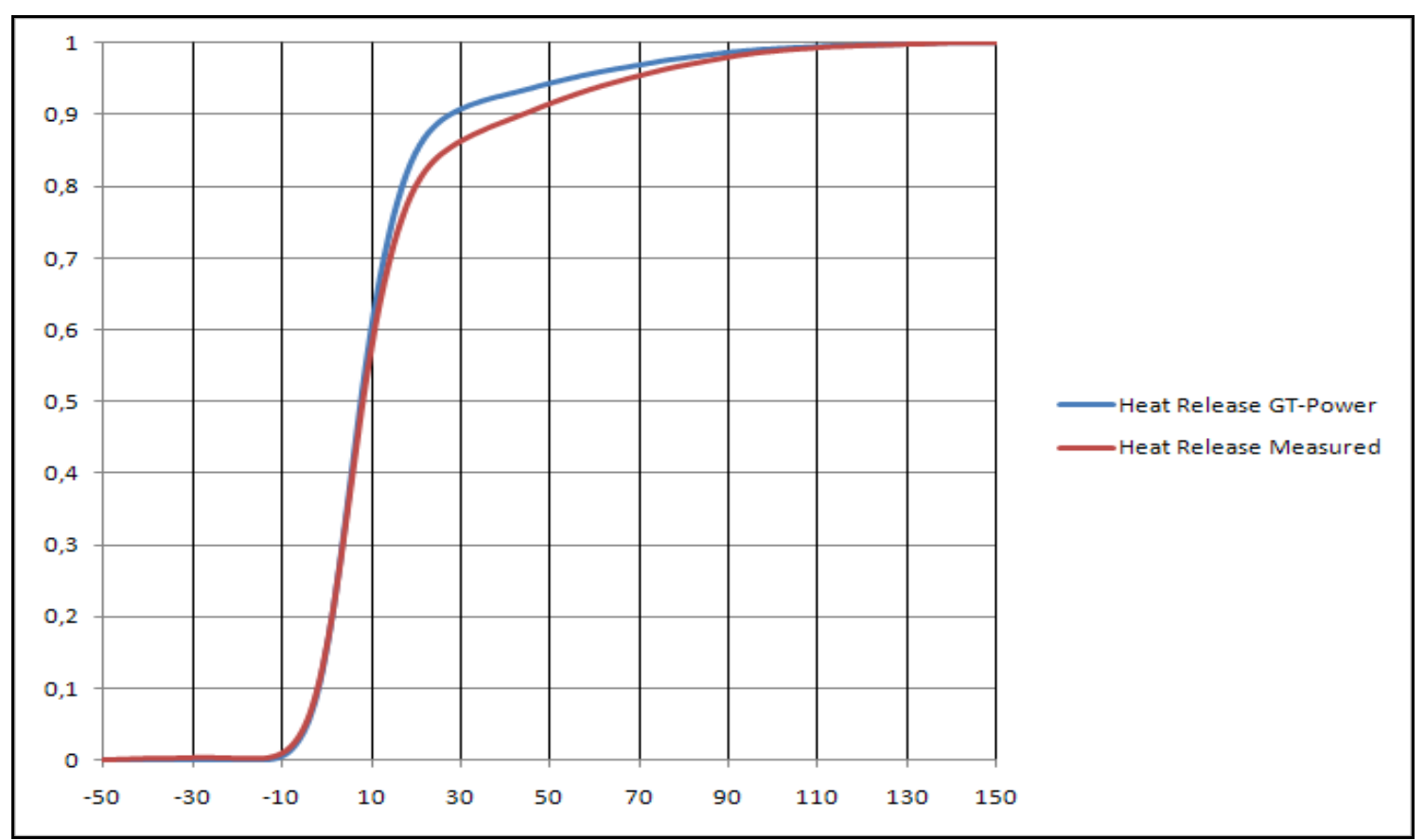

Figura 46 - Comparativo de "heat release". 


\section{SI Wiebe Burn Rate \& Comparison}

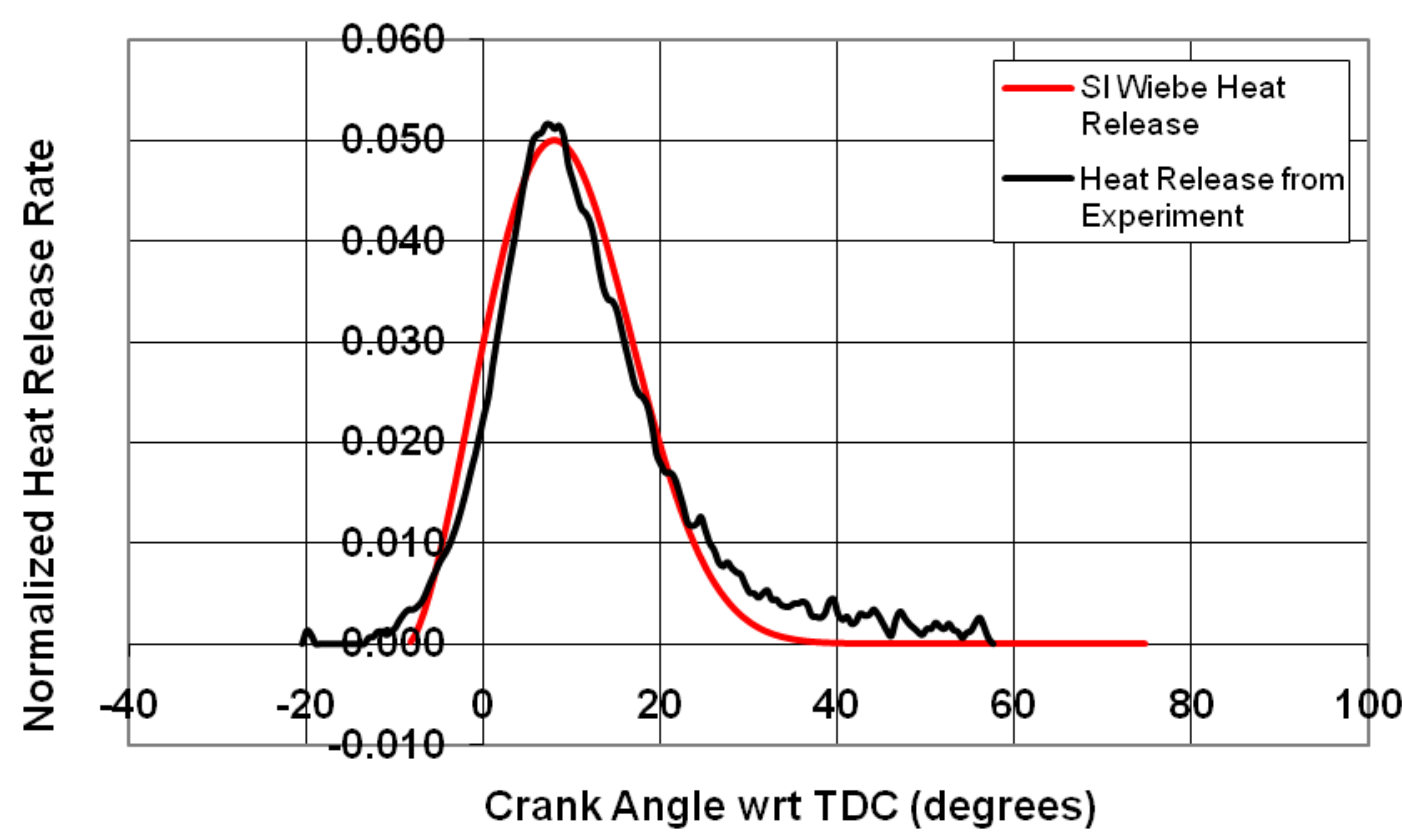

Figura 47 - Comparativo de "burn rate".

\subsection{MODELO DE CHAMA TURBULENTA (SPARK-IGNITION TURBULENT}

\section{FLAME MODEL)}

Modelo preditivo utilizado para mistura homogênea que leva em conta a geometria da câmara de combustão, avanço de ignição, movimento da mistura e propriedades do combustível. A dinâmica da frente de chama é governada pelas três equações a seguir:

$$
\begin{aligned}
& \frac{d M_{e}}{d t}=\rho_{u} A_{e}\left(S_{T}+S_{L}\right) \\
& \frac{d M_{b}}{d t}=\frac{\left(M_{e}-M_{b}\right)}{\tau} \\
& \tau=\frac{\lambda}{S_{L}}
\end{aligned}
$$

Onde: 
$M_{e}=$ Massa penetrante na frente de chama proveniente da mistura não queimada;

$t=$ tempo;

$\rho_{u}=$ densidade da massa não queimada;

$A_{e}=$ Área da frente de chama;

$S_{T}=$ Velocidade de chama turbulenta;

$S_{L}=$ Velocidade de chama laminar;

$M_{b}=$ Massa queimada;

$\tau=$ Constante de tempo;

$\lambda=$ Comprimento da microescala de Taylor.

Estas equações estabelecem que a mistura não queimada penetra na frente de chama através da sua área a uma taxa proporcional à soma das velocidades laminar e turbulenta dessa frente de chama.

A taxa de queima é proporcional à quantidade de massa não queimada atrás da frente de chama $\left(\mathrm{M}_{\mathrm{e}}-\mathrm{M}_{\mathrm{b}}\right)$, dividida por uma constante de tempo $\tau$ que, por sua vez, é calculada dividindo-se a micro escala de Taylor $\lambda$ pela velocidade laminar da chama.

Esse modelo depende fortemente de uma prévia calibração baseada em dados experimentais.

\subsection{ANÁLISE POR TRÊS PRESSÕES (THREE PRESSURE ANALYSIS (TPA))}

Algumas quantidades são muito difíceis, ou mesmo impossíveis de ser mensuradas com acuracidade em um motor real, por isso, um procedimento muito comum é isolar um cilindro do motor e impor condições de fronteiras usando dados de medidas de pressão que nos permita predizer tais grandezas como: gás residual, fluxo de massa nas válvulas, taxa de queima, etc. Um requisito para essa técnica é tomar três pontos de medidas de pressões. Duas 
dessas medidas são feitas nos pórticos de admissão e descarga, respectivamente, e a terceira no interior do cilindro. Essas medidas devem ter resoluções baseadas em ângulos de virabrequim, não sendo suficientes medidas de pressões médias nos pórticos, como é muito comum de se fazer. Temperaturas médias são requeridas para o método em questão.

Em resumo:

- Pressão no pórtico de admissão - Pressão instantânea medida depois dos injetores (Port Fuel Injection)

- Pressão no pórtico de descarga - Pressão instantânea

- Pressão no cilindro - Pressão instantânea

- Temperatura nos pórticos - Temperatura média no mesmo ponto onde as pressões foram medidas

- Fração de EGR - Descarga média de EGR

Equacionamento:

$$
\frac{d\left(m_{t o t} e_{t o t, f}\right)}{d t}=-p \frac{d V_{t o t}}{d t}-Q_{t o t}-\frac{d\left(m_{t o t} e_{t o t, s}\right)}{d t}
$$




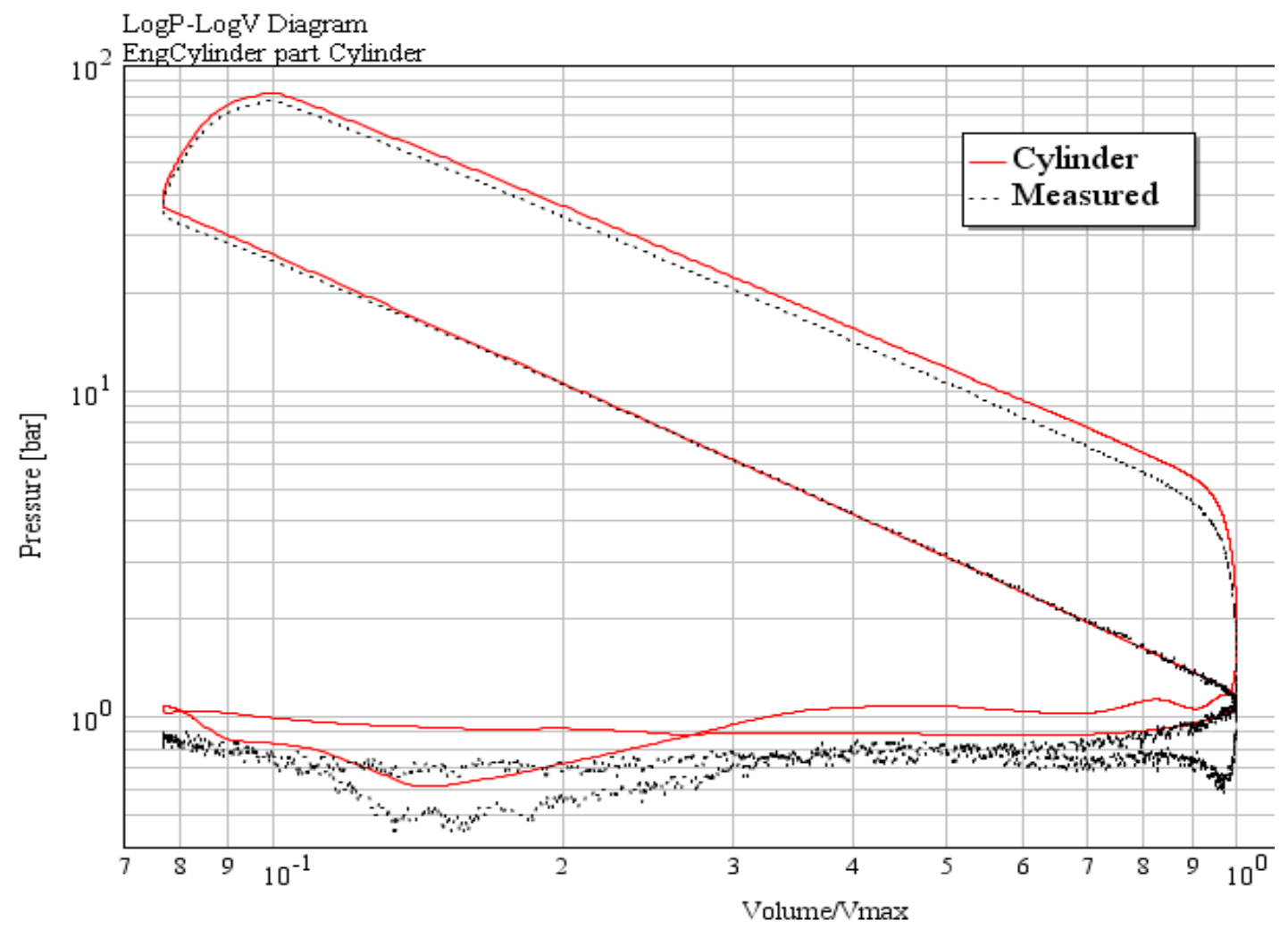

Figura 48 - Calibração do modelo 1D.

A Figura 48 representa uma tentativa de calibração do modelo 1D a partir de uma curva de pressão no interior do cilindro medida experimentalmente (Diagrama $\mathrm{P}$ x V). 


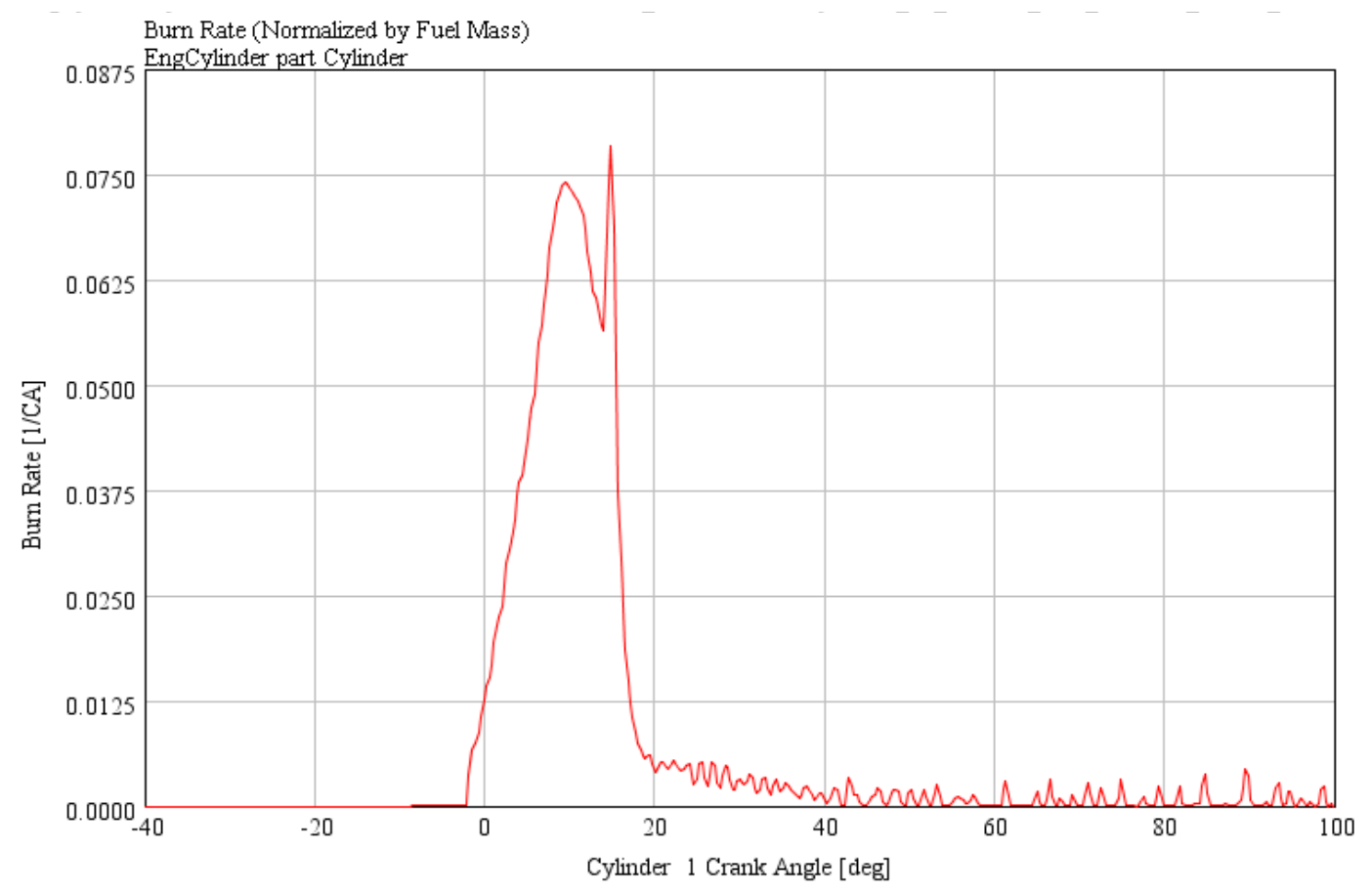

Figura 49 - Simulação de uma combustão anormal.

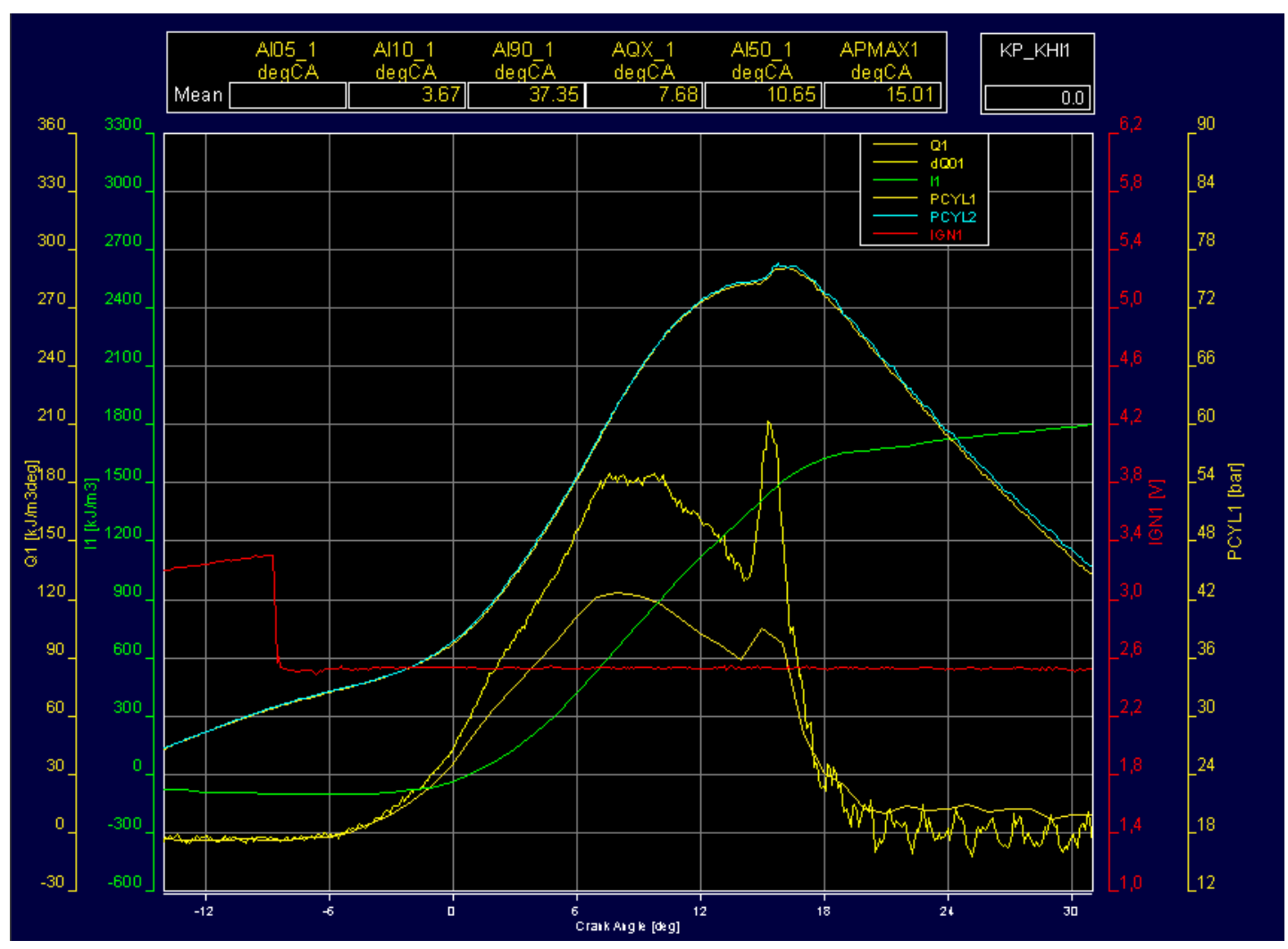

Figura 50 - Resultados experimentais de uma combustão anormal. 
As duas figuras acima (Figura 49 e Figura 50) representam, respectivamente, a simulação 1D e análise experimental de uma combustão anormal (ressaltos nas curvas azul e amarela).

A curva azul do segundo quadro é a curva de pressão no cilindro e as amarelas a taxa de queima (sinal filtrado e não filtrado).

\subsection{MODELO DE COMBUSTÃO POR MÚLTIPLAS ZONAS (MULTI-ZONE COMBUSTION)}

Modelo empregado para predição de combustão de diesel que normalmente utiliza acima de 500 zonas principais. Cada uma dessas zonas principais contém três subzonas para líquido não queimado, mistura ar-combustível não queimada e gás queimado. As zonas, queimada e não queimada, sempre são modeladas com temperaturas diferentes. 


\section{MODELAMENTO 3D DE COMBUSTÃO (CFD)}

\subsection{COMBUSTÃO COM CHAMA PRÉ-MISTURADA (PREMIXED COMBUSTION)}

No modelo de combustão pré-misturada adotado, combustível e ar são misturados ao nível molecular primordial para a ignição. A combustão se propaga isotropicamente como uma frente de chama que avança pelos reagentes na câmara de combustão.

Modelos de chamas pré-misturadas costumam ser mais complexos do que não prémisturadas, devido ao fato do primeiro ocorrer em uma fina camada da frente de chama, que, geralmente, é distorcida pela turbulência. Para fluxos subsônicos, a taxa de propagação da frente de chama é determinada pelas parcelas correspondentes às velocidades laminar e turbulenta.

\subsubsection{Limitações}

Modelo válido apenas para fluxos com velocidades subsônicas, específico do presente trabalho.

Esse modelo também não pode ser usado em conjunção com modelos de formação de poluentes, como fuligem e $\mathrm{NO}_{\mathrm{X}}$, por exemplo. Entretanto, é possível acoplá-lo a um modelo de chama parcialmente pré-misturada para esse fim. 


\subsubsection{Modelo de Zimont}

Esse trabalho se baseia no modelo de chama turbulenta pré-misturada de Zimont, que envolve a solução da equação de transporte pelo progresso das variáveis reatantes. A condição de clausura (fechamento) das equações é baseada na definição de velocidade de chama turbulenta.

\subsubsection{Propagação da Frente de Chama}

A propagação da frente de chama é modelada resolvendo-se a equação de transporte para $c$ (mean reaction progress variable), como se segue:

$$
\frac{\partial(\rho c)}{\partial t}+\nabla \cdot(\rho \vec{v} c)=\nabla \cdot\left(\frac{\mu_{t}}{S c_{t}} \nabla c\right)+\rho S_{c}
$$

Onde:

$$
\begin{aligned}
& c=\text { Variável de progresso de reação; } \\
& S c_{t}=\text { Número de Schmidt (turbulento); } \\
& S c=\text { Termo fonte de progresso de reação }\left(s^{-1}\right) .
\end{aligned}
$$

Sendo $c$ definida como uma soma normalizada dos produtos da reação, ou seja:

$$
c=\frac{\sum_{i=1}^{n} Y_{i}}{\sum_{i=1}^{n} Y_{i, e q}}
$$

Onde:

$n=$ Número de produtos;

$Y_{i}=$ Fração de massa do produto da espécie $i$;

$Y_{i, e q}=$ Equilíbrio da fração de massa do produto de espécie $i$. 
Com base nessa definição, tem-se $c=0$ quando a mistura ainda não foi queimada, e $c=1$ quando queimada.

O valor de $c$ é definido como uma condição de fronteira para todos os fluxos entrantes.

A taxa de reação na equação principal é modelada como sendo:

$$
\rho S_{c}=\rho_{u} U_{t}|\nabla c|
$$

Onde:

$$
\begin{aligned}
& \rho_{u}=\text { Densidade da mistura não queimada } \\
& U_{t}=\text { Velocidade de chama turbulenta. }
\end{aligned}
$$

\subsubsection{Velocidade de Chama Turbulenta}

A chave do modelo de combustão pré-misturada é a predição de $\boldsymbol{U}_{\boldsymbol{I}}$, ou seja, a velocidade de chama turbulenta normal à superfície da chama. Essa velocidade é influenciada pela própria velocidade laminar que, por sua vez, é determinada pela concentração de combustível, temperatura, as propriedades difusivas das moléculas bem como sua cinética química.

A condição de clausura para a velocidade de chama turbulenta é completada usando um modelo para "wrinlded" e "thickened" frentes de chamas:

$$
U_{t}=A\left(u^{\prime}\right)^{3 / 4} U_{l}^{1 / 2} \alpha^{-1 / 4} l_{t}^{1 / 4}=A u^{\prime}\left(\frac{\tau_{t}}{\tau_{c}}\right)^{1 / 4}
$$

Onde:

$A=$ cte;

$u^{\prime}=$ Velocidade RMS;

$U_{l}=$ Velocidade de chama laminar;

$\alpha=\frac{\kappa}{\rho c_{p}}=$ Difusividade térmica (mistura não queimada);

$l_{t}=$ Escala turbulenta; 
$\tau_{t}=\frac{l_{t}}{u^{\prime}}=$ Escala de tempo (turbulência);

$\tau_{c}=\frac{\alpha}{U_{l}{ }^{2}}=$ Escala de tempo (reação química).

A dimensão da escala turbulenta é dada por:

$$
l_{t}=C_{D} \frac{\left(u^{\prime}\right)^{3}}{\varepsilon}
$$

Onde épsilon é o termo referente à taxa de dissipação.

O modelo é baseado no equilíbrio da microescala turbulenta na chama laminar, resultando em uma expressão para a velocidade de chama turbulenta que é estabelecida puramente em termos dos parâmetros da larga escala turbulenta

Esse modelo é aplicado estritamente quando os menores vórtices de turbulência no fluxo (escalas de Kolmogorov) são menores do que a espessura da frente de chama e penetra em seu interior. Pode-se quantificar essa fina região pelos números Karlovitz:

$$
\mathrm{K} a=\frac{t_{l}}{t_{\eta}}=\frac{v_{\eta}{ }^{2}}{U_{l}^{2}}
$$

Onde:

$t_{l}=$ Escala de tempo característica da chama;

$t_{\eta}=$ Menor escala de tempo de Kolmogorov (turbulência);

$v_{\eta}=(v \varepsilon)^{1 / 4}=$ Velocidade de Kolmogorov;

$v=$ Viscosidade sinamática.

\subsubsection{Cálculo da Temperatura Adiabática}

No caso adiabático, assume-se uma função linear da temperatura com a taxa de reação entre a menor temperatura da mistura não queimada $\left(\mathbf{T}_{\mathbf{u}}\right)$ e a maior temperatura da parte queimada $\left(\mathbf{T}_{\mathbf{a d}}\right)$ : 


$$
T=(1-c) T_{u}+c T_{a d}
$$

\subsubsection{Cálculo da Temperatura Não-Adiabática}

No caso não adiabático, resolve-se a equação de transporte de energia. como mostrado a seguir:

$$
\frac{\partial}{\partial t}(\rho h)+\nabla \cdot(\rho \vec{v} h)=\nabla \cdot\left(\frac{\kappa+\kappa_{t}}{c_{p}} \nabla h\right)+S_{h, c h e m}+S_{h, \text { rad }}
$$

Onde $S_{h, r a d}$ representa a perda de calor por radiação, e $S_{h, c h a m}$ o ganho de calor da reação química:

$$
S_{h, \text { chem }}=\rho S_{c} H_{\text {comb }} Y_{\text {fuel }}
$$

Onde:

$S_{c}=$ Taxa média de formação de produto (normalizada);

$H_{\text {comb }}=$ Poder calorífico (combustão);

$Y_{f u e l}=$ Fração de massa de combustível da mistura não queimada.

\subsubsection{Cálculo da Densidade}

Usando a consideração de gás ideal, condição adiabática, e desprezando as variações de pressão e assumindo a massa molecular média constante, tem-se:

$$
\rho_{b} T_{b}=\rho_{u} T_{u}
$$

Onde o sub-índice $\boldsymbol{u}$ se refere à mistura não-queimada (fria) e o sub-índice $\boldsymbol{b}$ se refere à porção queimada (quente).

Como dados de entrada tem-se a densidade, a temperatura da mistura não-queimada, e a temperatura de chama adiabática. 
Para o caso não adiabático, tem-se:

$$
\rho T=\rho_{u} T_{u}
$$

\subsubsection{Modelo de Ignição (spark)}

A equação de transporte para $c$ (mean reaction progress variable) é dada por:

$$
\frac{\partial \rho c}{\partial t}+\nabla \cdot(\rho \vec{v} c)=\nabla \cdot\left(D_{t} \nabla c\right)+\rho_{u} U_{t}|\nabla c|
$$

Onde $\boldsymbol{D}_{\boldsymbol{i}}$ é a difusividade turbulenta, $\boldsymbol{\rho}_{\boldsymbol{u}}$ é a densidade da mistura não-queimada, e $\boldsymbol{U}_{\boldsymbol{i}}$ é a velocidade de chama turbulenta.

Uma vez que a região da centelha costuma ter dimensões menores que o da malha envolvida na simulação, e esse início de combustão (spark) possui natureza laminar, o modelo de Zimont sofre a seguinte modificação:

$$
\frac{\partial \rho c}{\partial t}+\nabla \cdot(\rho \vec{v} c)=\nabla \cdot\left(\left(\kappa+D_{t t}\right) \nabla c\right)+\rho_{u} U_{t}|\nabla c|
$$

Onde $\boldsymbol{\kappa}$ é a difusividade térmica laminar, e a difusividade efetiva $\boldsymbol{D}_{\boldsymbol{u}}$ é dada por:

$$
\begin{array}{ll}
D_{t t}=D_{t}\left(1-\exp \left(\frac{-t_{t d}}{\tau^{\prime}}\right)\right) & \text { se } t_{t d} \geq 0 \\
D_{t t}=D_{t} & \text { se } t_{t d} \prec 0
\end{array}
$$

Onde $\boldsymbol{t}_{\boldsymbol{i} \boldsymbol{d}}=\boldsymbol{t}-\boldsymbol{t}_{\boldsymbol{i g}}$ e $\boldsymbol{t}_{\boldsymbol{i g}}$ denota o instante em que a centelha é disparada.

\subsection{MODELO DE COMBUSTÃO COM CHAMA NÃO PRÉ-MISTURADA}

No modelo de combustão não pré-misturada, o combustível e o comburente reagem em regiões distintas do domínio. O modelo consiste na solução das equações de transporte para um ou dois escalares (frações da mistura). Não são resolvidas equações para espécies individuais; em vez disso, concentrações de espécies são derivados das frações de misturas previstas. Esse modelo tem sido empregado especificamente em simulação de chamas difusas 
turbulentas, como formulação "eddy-dissipation", por exemplo. Ele também permite a predição de espécies intermediárias (radicais). 


\section{SETUP DO CÓDIGO CFD}

\subsection{SOLVER}

Há dois métodos possíveis para escolha de "solvers" no FLUENT 6.2.16, o segregado (segregated) e o acoplado (coupled), pelos quais serão integradas as equações de conservação de massa, momento, energia e outros escalares como turbulência, por exemplo. Em ambos os casos, uma técnica baseada em volumes de controles é empregada e consiste de:

1. Divisão do domínio em volumes de controles discretos usando uma malha computacional;

2. Integração das equações que governam o modelo individualmente nos volume de controles para construir equações algébricas para as variáveis discretas desconhecidas como: velocidade, pressão, temperatura, etc;

3. Linearização das equações discretas e das soluções dos sistemas de equações lineares.

Os dois métodos empregam processos de discretização similares (volumes finitos), mas a abordagem usada para linearizar e resolver as equações discretas é diferente. No método segregado, as equações são resolvidas numa determinada sequências, com cada iteração consistindo dos seguintes passos: 


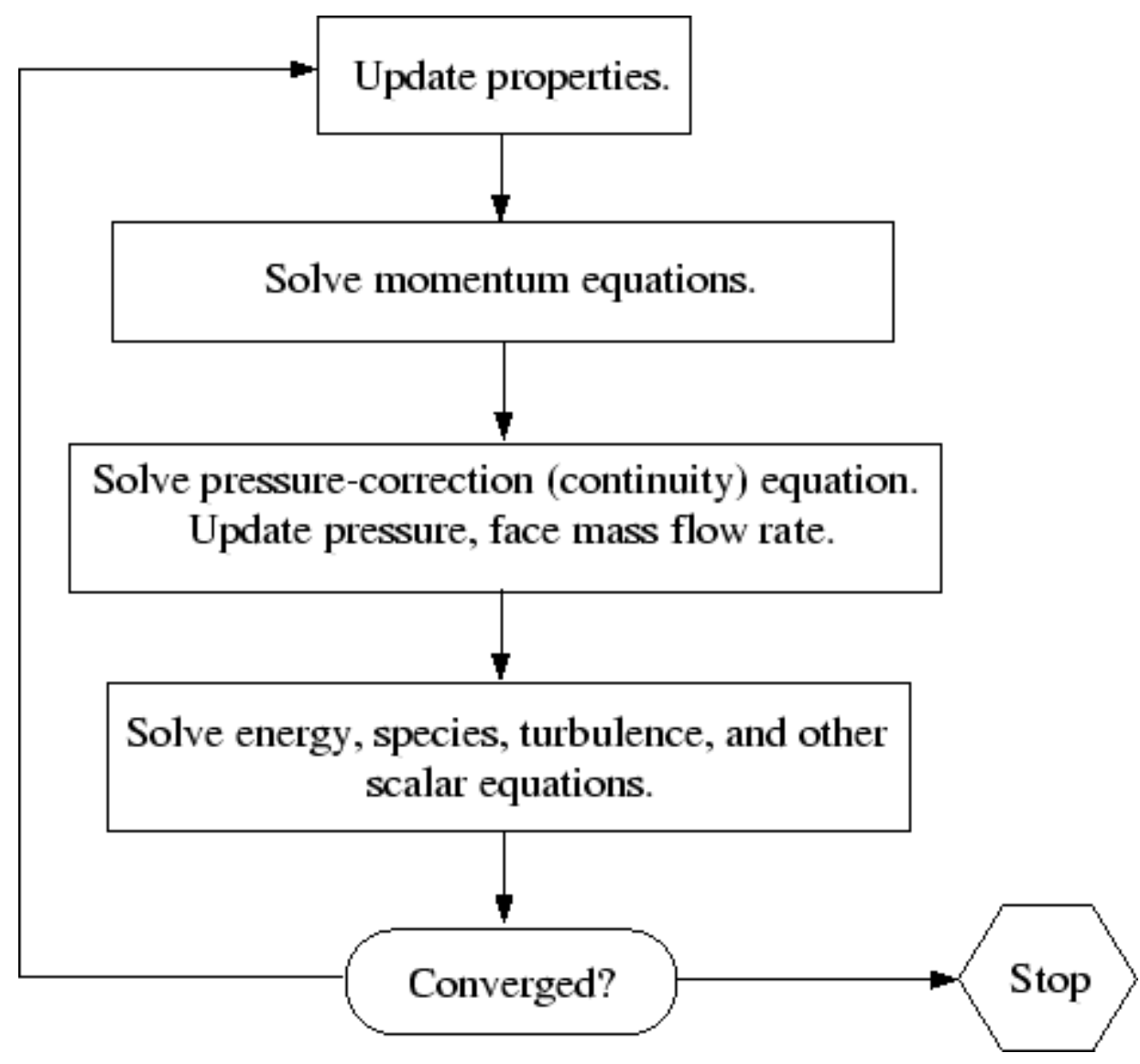

Figura 51 - Método segregado.

O "solver" acoplado resolve as equações de continuidade, momento, energia e transporte simultaneamente, como ilustrado a seguir. 


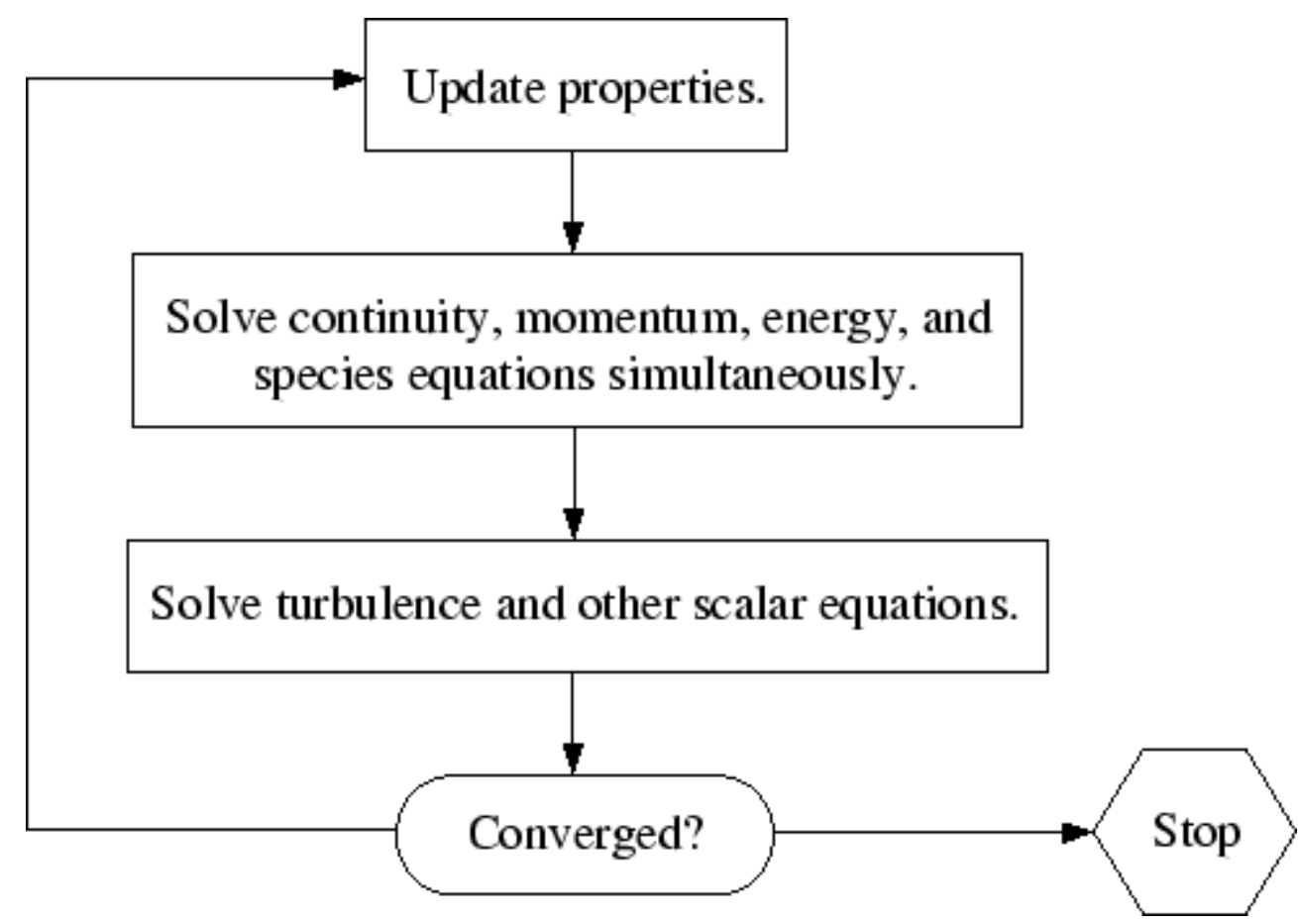

Figura 52 Método acoplado.

Em ambos os casos, o método de linearização pode ser do tipo "implícito" ou "explícito".

- Implícito: para uma dada variável, o valor desconhecido em cada célula é computado usando uma relação que inclui os valores conhecidos e desconhecidos da vizinhança da célula. Entretanto, cada valor desconhecido aparecerá em mais de uma equação no sistema, e essas equações devem ser solucionadas simultaneamente para obter as quantidades desconhecidas.

- Explícito: para uma dada variável, o valor desconhecido em cada célula é computado usando uma relação que inclui apenas valores conhecidos. Entretanto, cada valor desconhecido aparecerá em apenas uma equação no sistema, e as equações para os valores desconhecidos em cada célula podem ser solucionadas, uma de cada vez, para obter as quantidades desconhecidas.

No método de solução segregada, cada equação discreta é linearizada implicitamente em relação à variável independente da equação. Isso resulta em um sistema de equações lineares 
com uma equação para cada célula no domínio. Pelo fato de haver apenas uma equação por célula, às vezes esse sistema é chamado de sistema de equações escalares. Em resumo, a abordagem segregada resolve um simples campo de variável considerando todas as células ao mesmo tempo. Então, resolve-se para o próximo campo de variável também considerando todas as células simultaneamente, e assim por diante. Por isso, não há a opção do método explícito para soluções segregadas.

O método de soluções acopladas permite a escolha entre os métodos de linearização implícito e explícito. Na escolha da opção implícita para soluções acopladas, cada equação do sistema de equações é linearizada implicitamente com respeito a todas as variáveis dependentes. Isso resulta num sistema de equações lineares com $\mathrm{N}$ equações por célula.

$\mathrm{Na}$ escolha da opção explícita para soluções acopladas, cada equação do sistema de equações é linearizada explicitamente. Como no método implícito, isso resultará em um sistema de equações com $\mathrm{N}$ equações no domínio, no entanto, essa abordagem consiste de um sistema de equações explícitas nas variáveis dependentes desconhecidas. 


\section{MATERIAIS E MÉTODOS}

\subsection{SIMULAÇÃO}

Em uma primeira etapa, houve a necessidade de definição do software (código comercial) que seria utilizado para as simulações de CFD que pudessem atender aos requisitos da proposta de trabalho, pois não havia o intuito de desenvolvê-lo. A escolha do código FLUENT se baseou principalmente no fato de ser amplamente usado pela indústria automotiva em diversas áreas sem ser um código modular, que demandasse a inserção de pacotes adicionais para a solução de novos modelos computacionais, além de se confugurar como algo mais customizável. Em contrapartida, outros códigos comerciais desenvolvidos especificamente para motores possuíam bibliotecas específicas que facilitariam os "setups" para as primeiras simulações, como o STAR-CD, por exemplo, cujas maiores dificuldades são os fatos de não haver uma equipe de suporte no Brasil no período em questão e ser pouco customizável.

Hoje, o FLUENT faz parte de um único pacote que integra o CFX e o HIPERMESH, entre outros, compondo o ANSYS.

As geometrias envolvidas foram geradas com o SOLID EDGE 17 e exportadas no formato STL para a geração de malhas computacionais pelo GAMBIT e tratadas pelo TGRID, sendo esses dois últimos pré-processadores do FLUENT. 
A utilização do GT-POWER para soluções de problemas 1D teve o intuito de promover melhores condições de fronteiras para a simulação 3D, devido à dificuldade de se medirem determinados parâmetros experimentalmente.

Em linhas gerais, o trabalho de simulação consistiu em:

- Calibração do modelo 1D do motor Diesel Ottorizado por meio de confrontação com dados experimentais e obtenção de dados de entrada para simulação 3D;

- Geração de geometria 3D, malhas superficiais e volumétricas não estruturadas, e tratamento das malhas;

- Discretização de superfícies e volumes, aplicação das condições de contornos e definições de malhas móveis;

- Simulação de escoamento frio (não reativo), permitindo a análise do processo de formação da mistura;

- Simulação de combustão e comparação da curva de pressão com dados experimentais (calibração) e determinação da taxa de queima;

- Análise comparativa da taxa de queima para diferentes geometrias da câmara de combustão no pistão (“bowl”).

\subsection{ETAPA EXPERIMENTAL}

Para o levantamento de dados experimentais foram utilizados os itens descritos a seguir.

\subsubsection{Motor de Pesquisa FEV}

O motor apresentado a seguir é um FEV monocilíndroco desenvolvido para permitir que o pesquisador mude parâmetros de funcionamento com a máxima simplicidade, desde razão de compressão, estrutura de fluxo de admissão de ar, cruzamentos de válvulas até a configuração do sistema de injeção (direta ou indireta). Além disso, possibilita controle de temperatura de diversas partes do motor separadamente e adaptações de sensores de pressão 
no interior do cilindro, e ainda detecção do ponto em que ocorre autoignição na câmara de combustão. A seguir serão mostrada algumas características desse motor e sistemas auxiliares de medida.

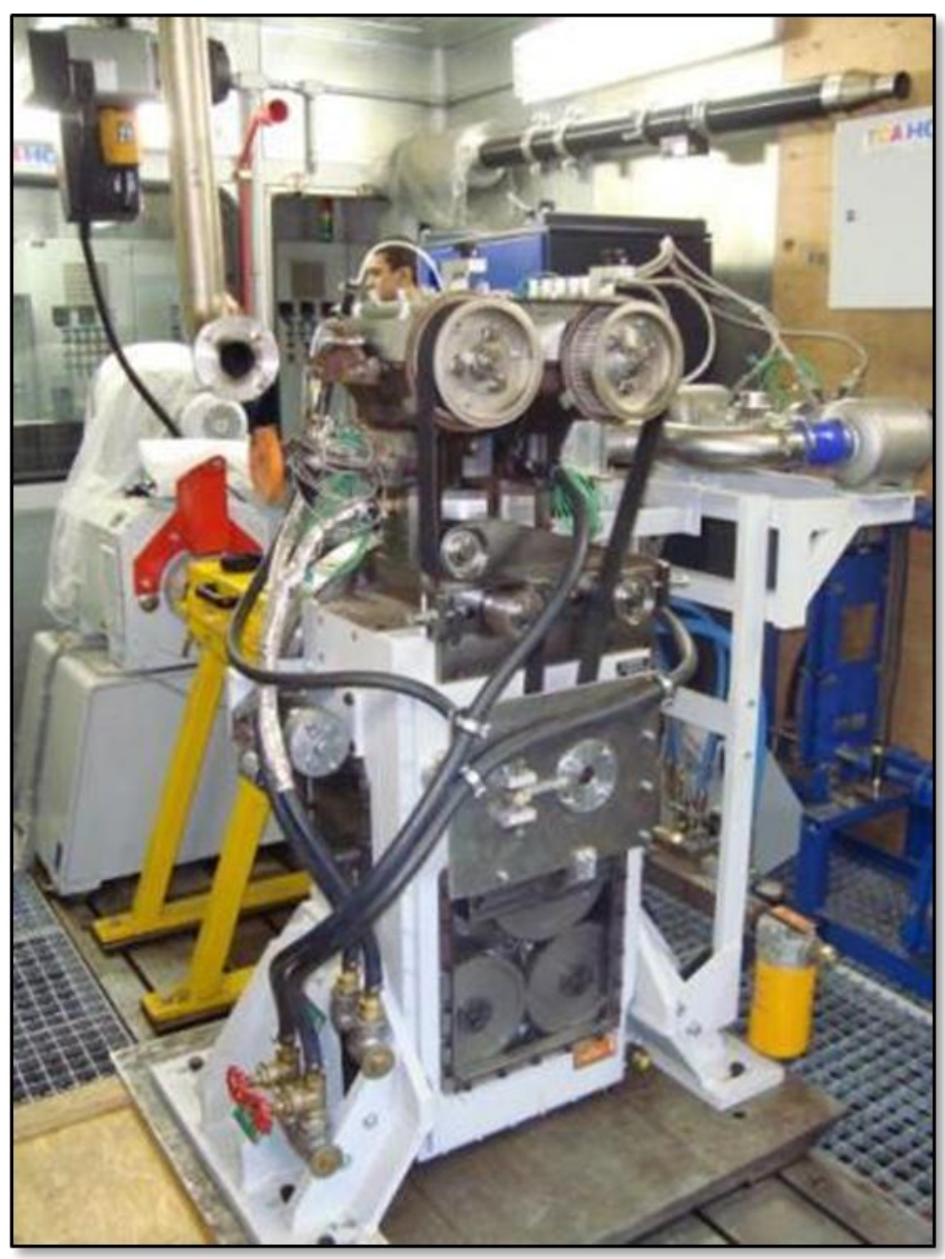

Figura 53 - Motor FEV.

A Figura 53 mostra uma visão frontal do motor FEV montado em sua bancada dinamométrica. 


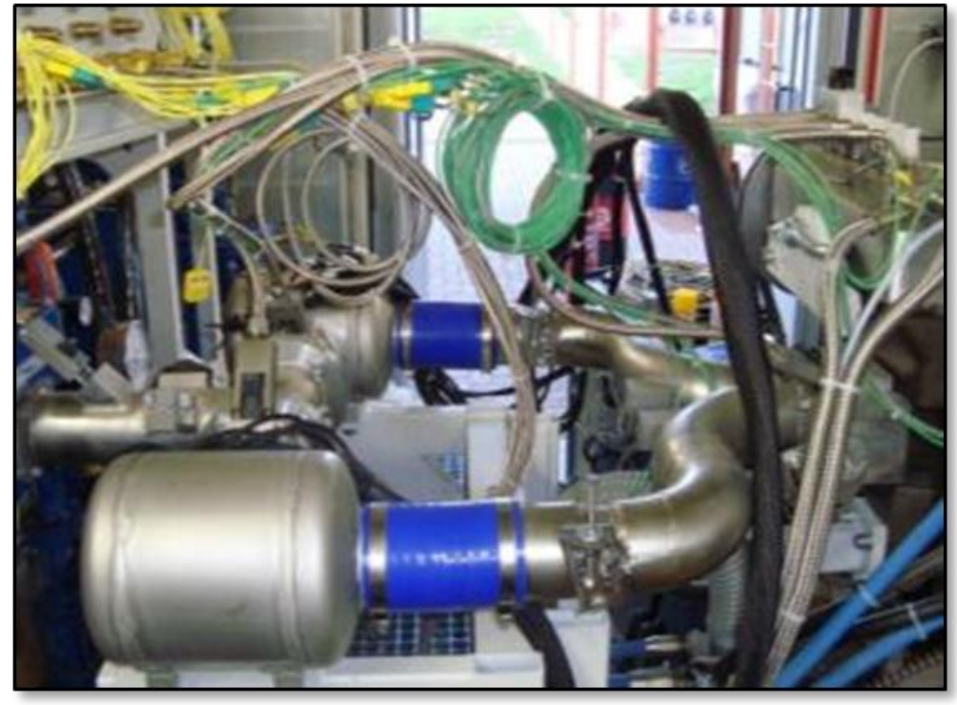

Figura 54 - Visão dos termopares.

Na Figura 54 podem-se ver os diversos termopares (fios amarelos) responsáveis pelas medições de temperaturas de todos os pontos relevantes para os ensaios em questão.

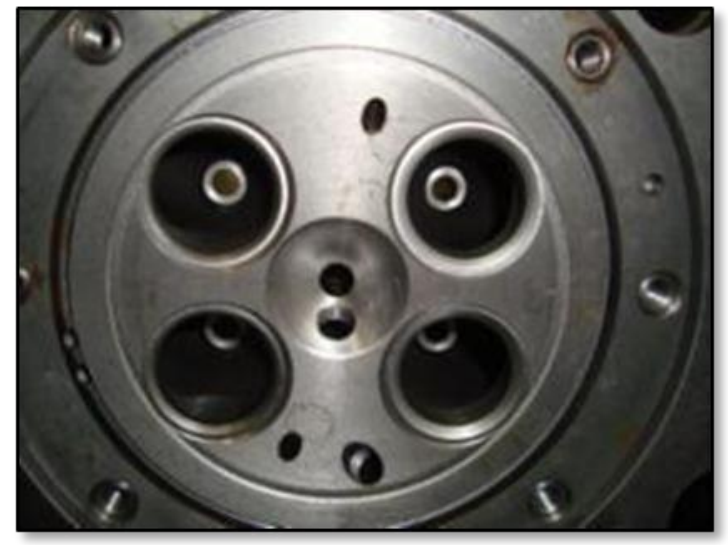

Figura 55 - Cabeçote do motor FEV.

Na Figura 55 tem-se um panorama da face do cabeçote onde se alojam as válvulas de admissão e descarga, especificamente, o objetivo é enfatizar os alojamentos para sensores de medidas de pressão piezoelétricos comumente utilizados nessa aplicação e para o sensor do sistema óptico "Visio Scope", que permite filmar o avanço da frente de chama e confrontar com as curvas de pressão medida e de liberação de calor calculada com base nessa curva de pressão. Abaixo, pode-se observar uma ilustração do "Visio Scope". 


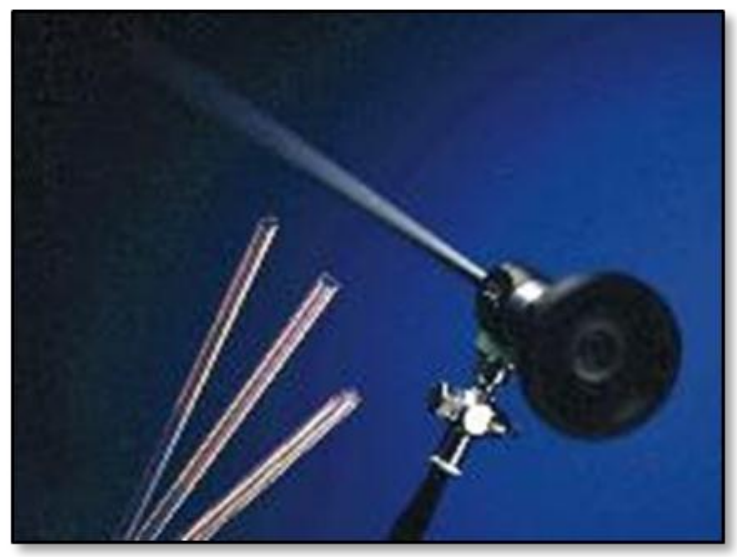

Figura 56 - Sensores ópticos.

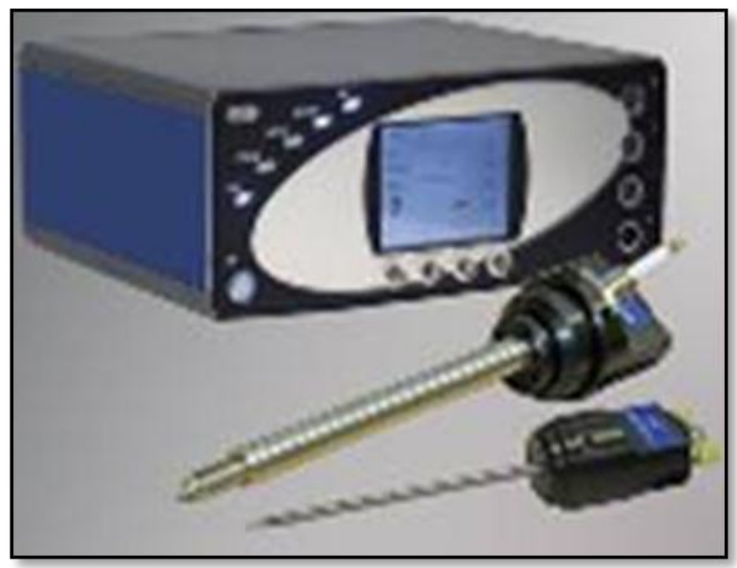

Figura 57 - Hardware do "Visio Scope".

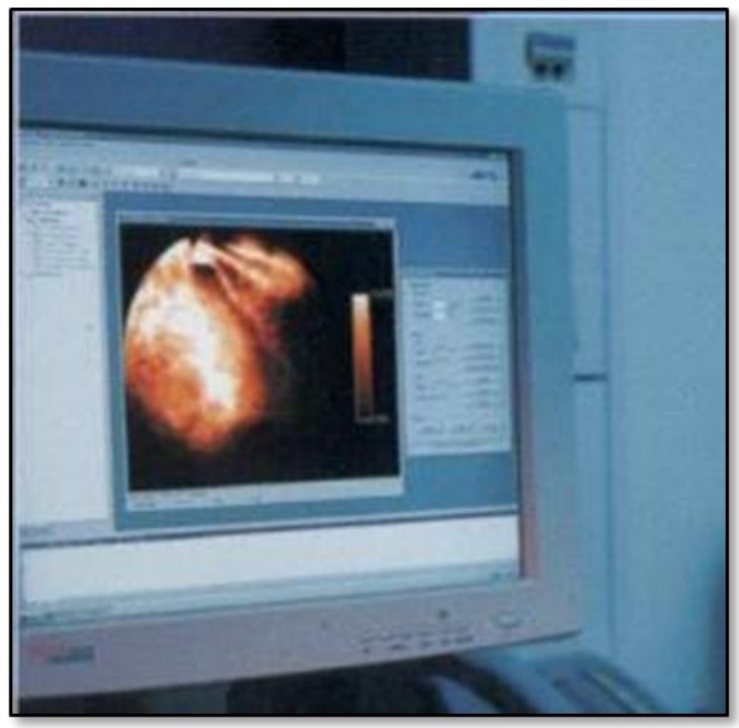

Figura 58 - Captura de imagem. 
Para quantificar a taxa instantânea de queima, utilizou-se o sistema "IndiModul" da AVL, que realizava a leitura da pressão no interior do cilindro com precisão de $0.1^{\circ}$ do virabrequim, precisão essa possibilitada pelo "encoder". A Figura 59 mostra o sistema IndiModul da AVL com suas interfaces IFEM, IndiCom, transdutor de pressão e encoder, e ilustra também curvas características como: Diagrama $\mathrm{P} \times \mathrm{V}$ (na escala log-log), taxa instantânea de queima e percentual de queima acumulado no ciclo.

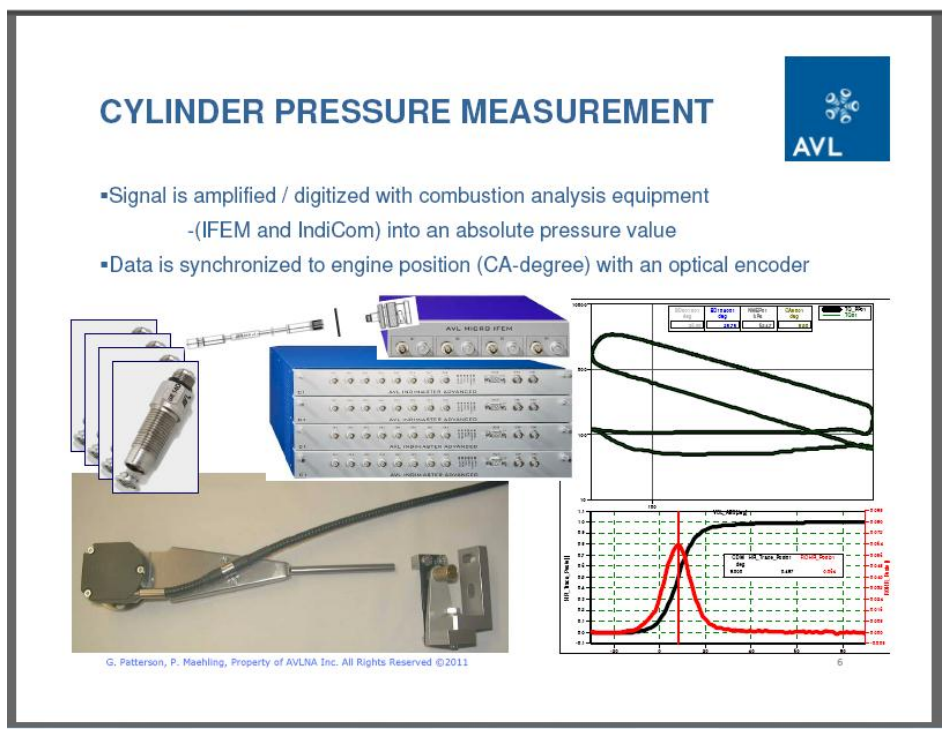

Figura 59 - IndiModul.

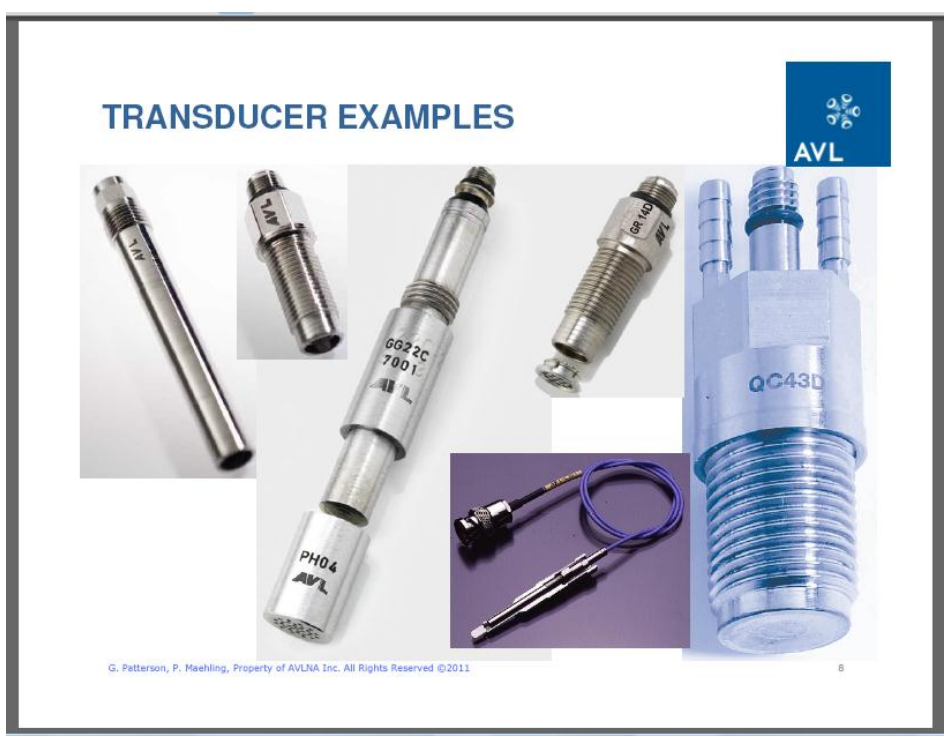

Figura 60 - Tipos de transdutores utilizados. 
Outro sensor importante é o de posicionamento do ponto morto superior para calibração junto ao "encoder" (Figura 61).

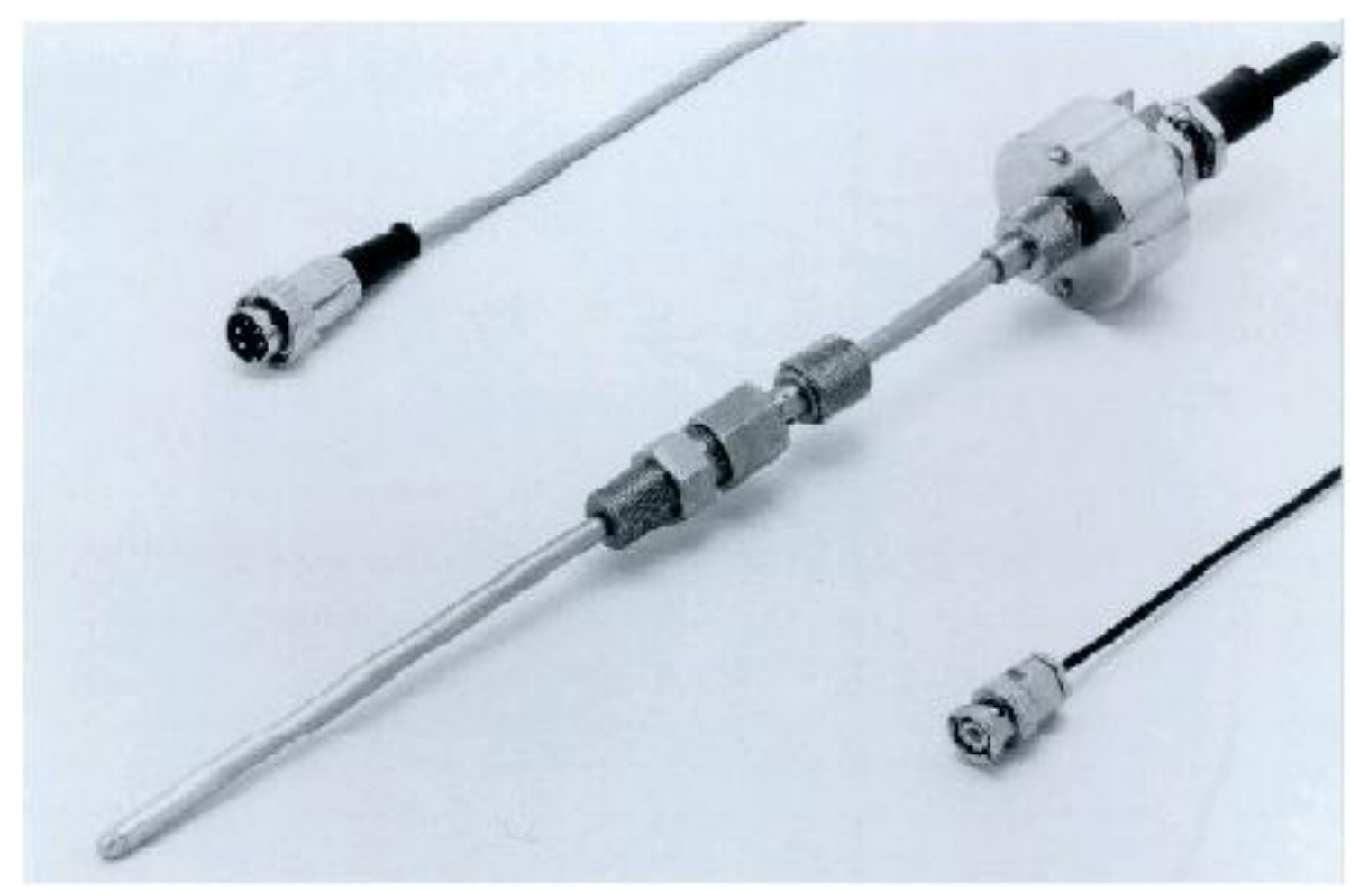

Figura 61 - Sensor de posicionamento do PMS. 


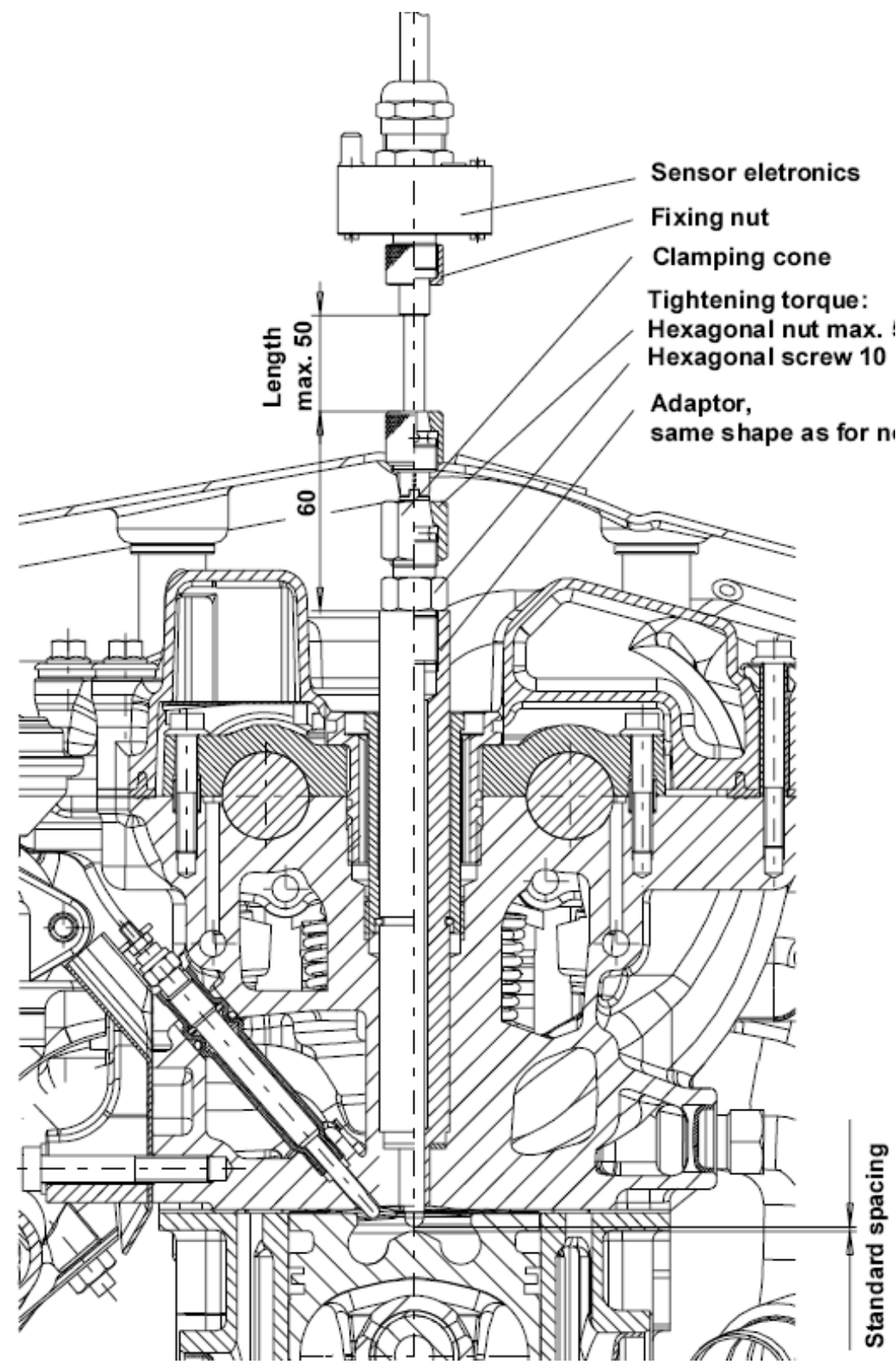

Figura 62 - Esquema de utilização do sensor de PMS. 


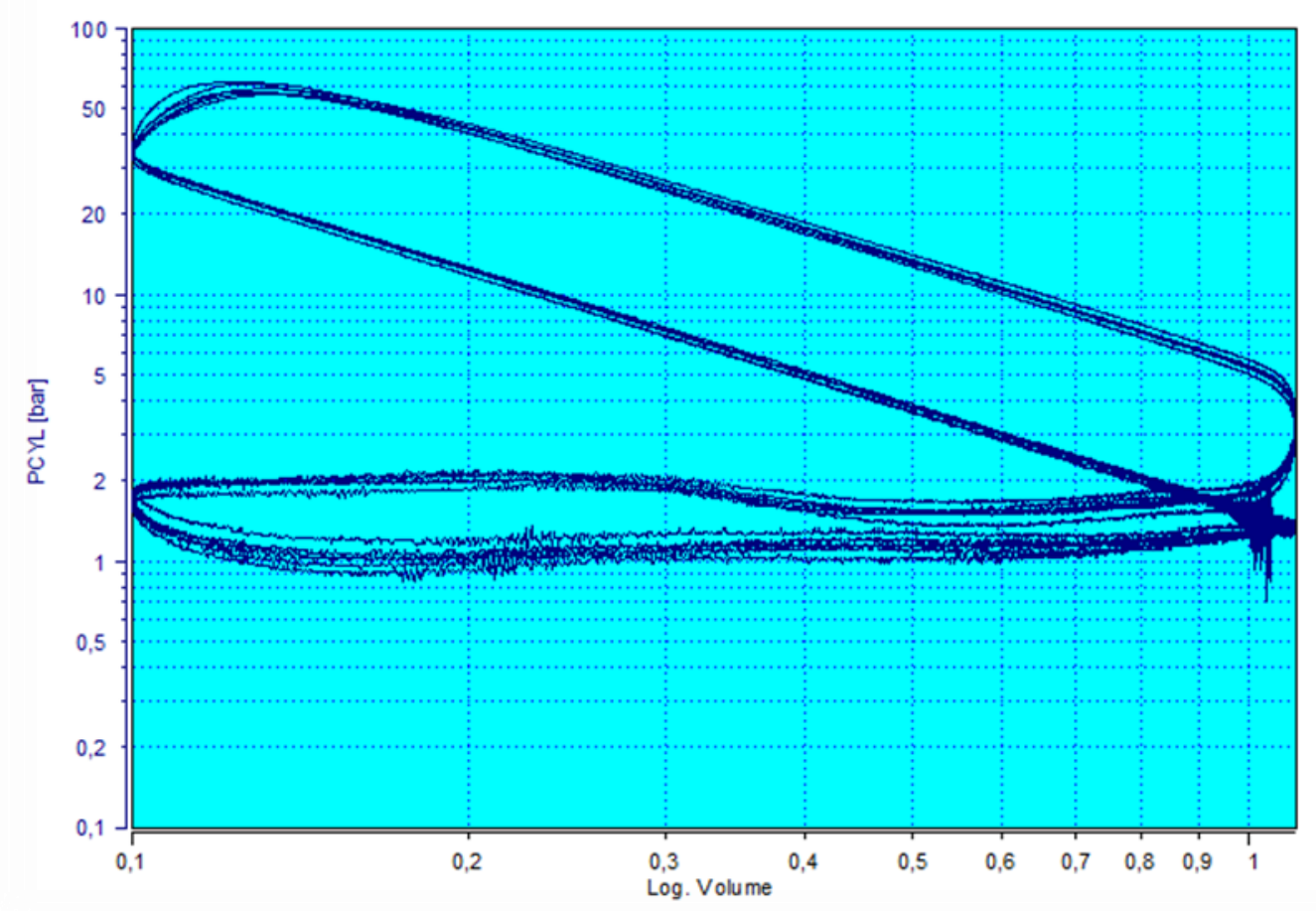

Figura 64 - Diagrama P x V.

Analisando o histórico de pressão no cilindro mostrado na Figura 65 obtido, por sua vez, dos testes com o motor FEV, pode-se notar certa anormalidade na combustão, aparentemente causada por uma autoignição da mistura não queimada, o que produz oscilações da pressão indicada pelo equipamento. A curva de liberação de calor, presente no mesmo gráfico, evidencia uma alta liberação de energia antes mesmo que $50 \%$ da mistura tenha sido queimada, o que também enfatiza a possibilidade de autoignição. 


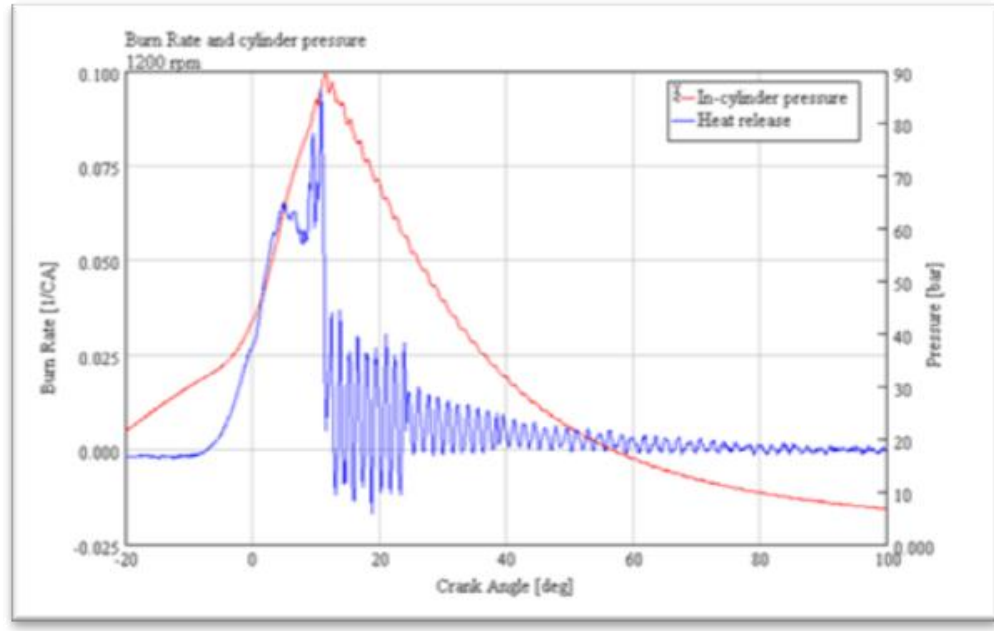

Figura 65 - Pressão no cilindro e taxa de queima.

A resposta em frequência da curva de pressão (Figura 65) foi construída conjuntamente com um caso sem a presença de oscilações de pressão e para uma rotação distinta com presença de oscilação. Através da Figura 66 é possível notar a presença de duas frequências de ressonância além da frequência característica, correspondente a maior amplitude, caracterizada pela rotação de trabalho. Tais frequências, não presentes no caso sem oscilação de pressão, se repetiram para as duas rotações distintas o que indica o mesmo fenômeno, resultante da provável autoignição para os dois casos.

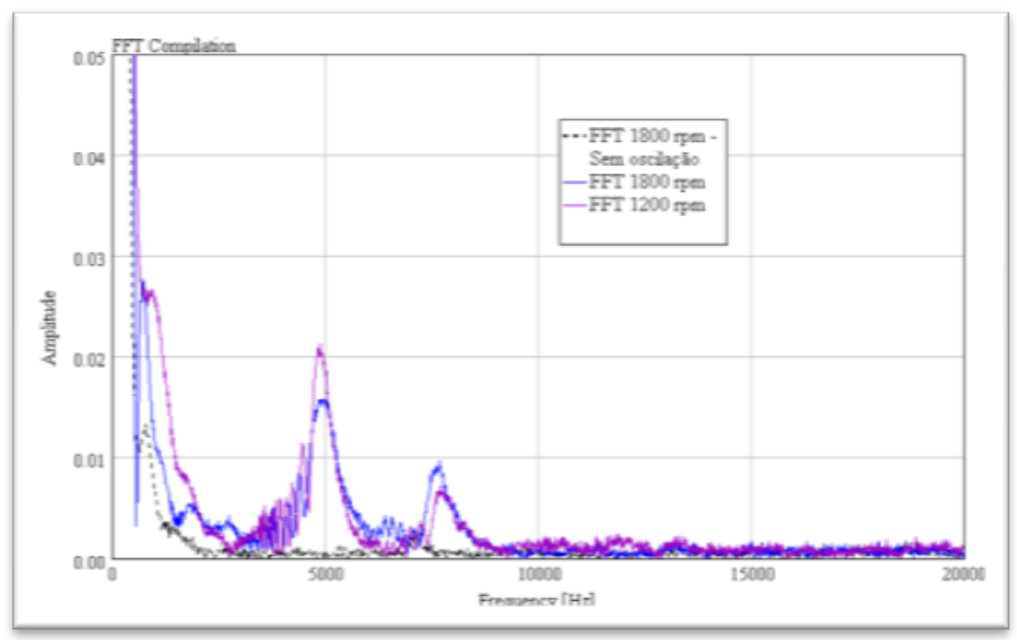

Figura 66 - Resposta em frequência. 


\subsubsection{Análise de Fluxo (PIV)}

O motor FEV pode gerar diferentes estruturas de fluxos para se obterem os índices de "swirl" e "tumble" desejados para cada aplicação específica de ensaios dinamométricos. Entretanto, para quantificá-los utiliza-se uma bancada de fluxo que quantifica os coeficientes de descargas, taxas de swirl e tumble acima mencionados, bem como registra a visualização esquemática das estruturas envolvidas no interior do cilindro por meio da técnica de PIV

A Figura 67 ilustra a bancada de fluxo com suas duas câmeras CCD, o laser e um cabeçote de teste FEV.

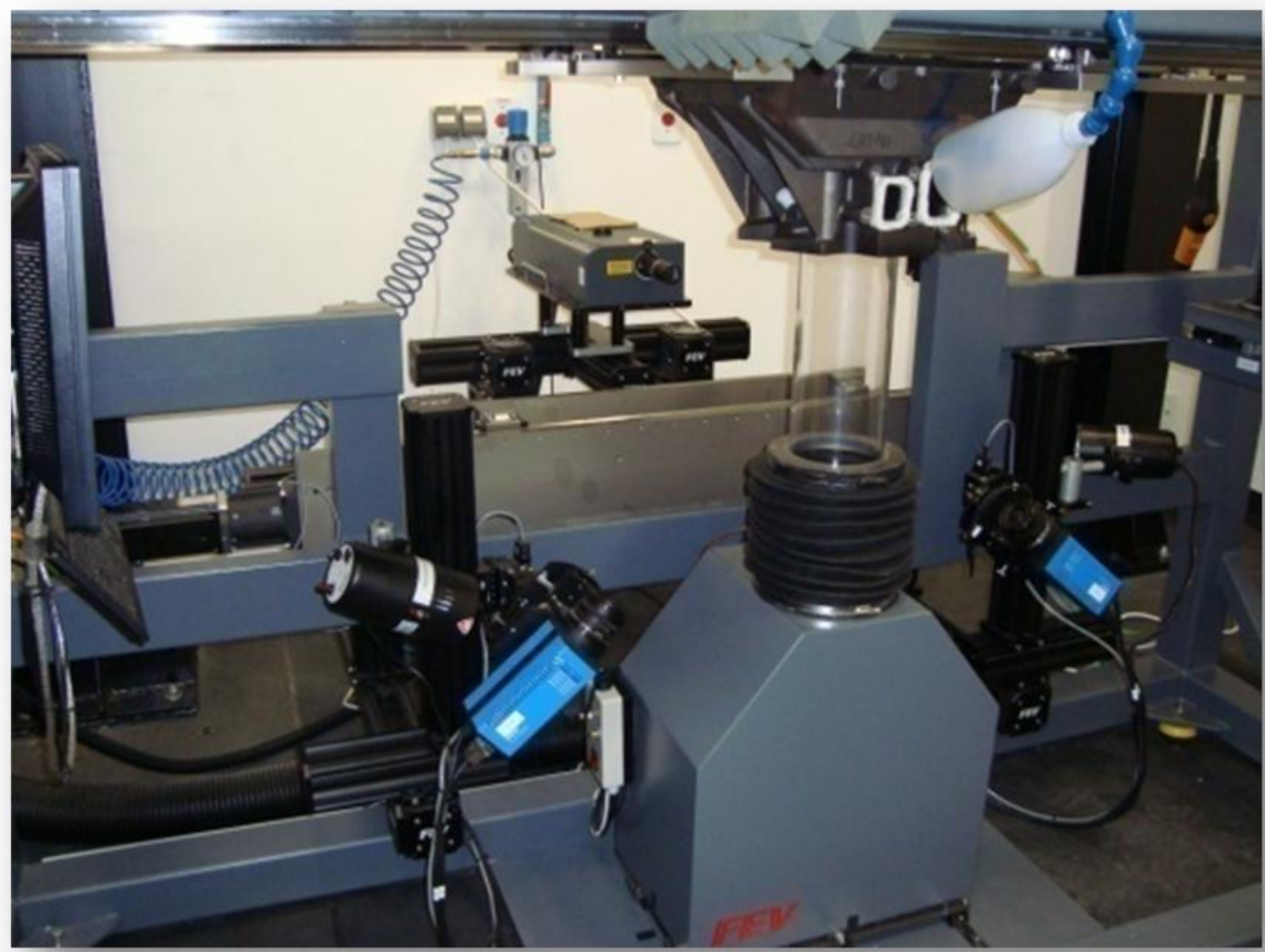

Figura 67 - Bancada de fluxo (PIV) 


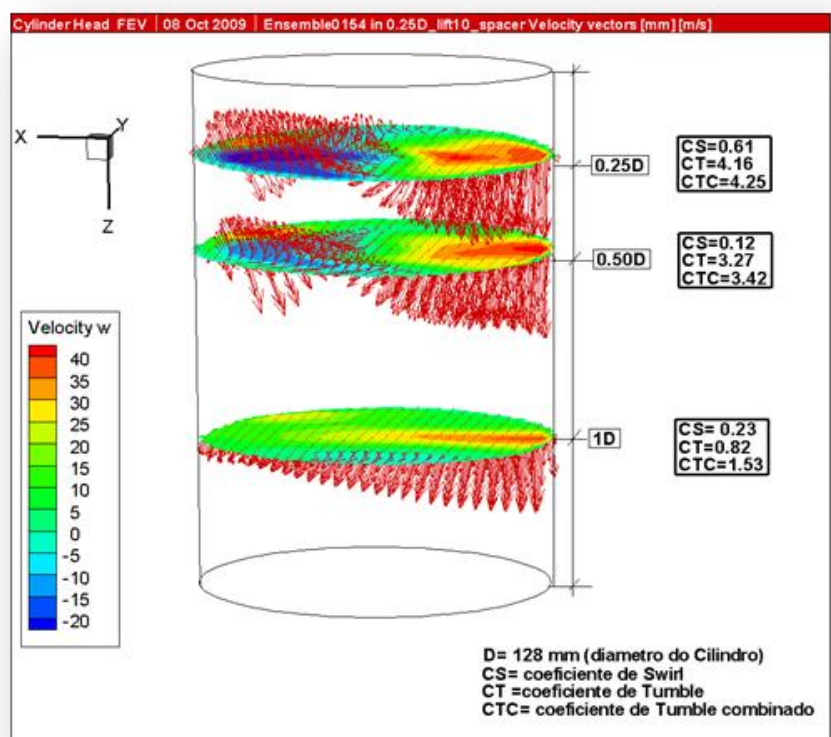

Figura 68 - Esquema tridimensional dos gradientes de velocidades

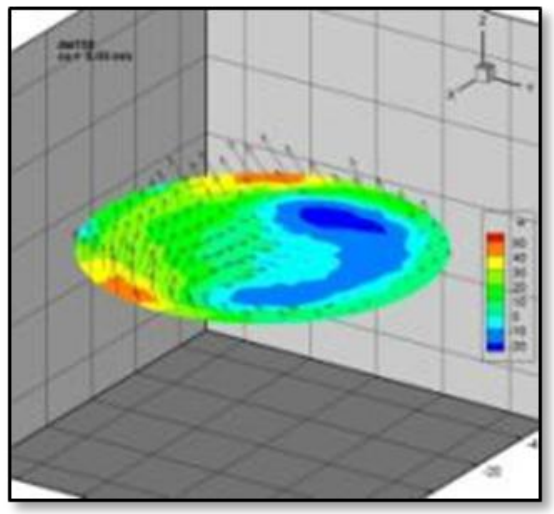

Figura 69 - Fluxo em uma secção transversal

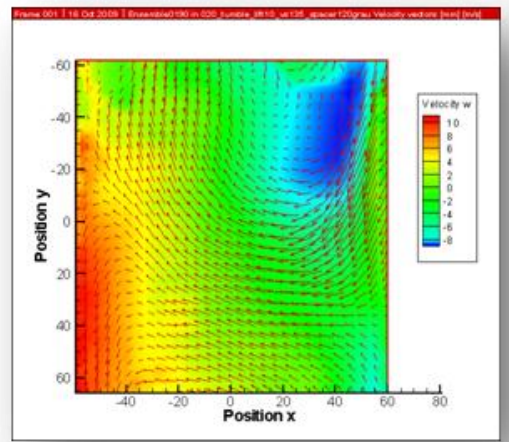

Figura 70 - Fluxo em uma secção vertical 


\subsubsection{Bancada de "Spray"}

Para estudos de injeção direta de combustível, faz-se necessário conhecer as características do spray injetado na câmara de combustão, uma vez que o mesmo vai interagir com paredes do cilindro e pistão. Isso deve ser bem conhecido, pois uma grande quantidade de combustível injetada que se choque com a parede do cilindro, pode danificar o motor como resultado de deficiência de lubrificação, além de gerar aumento dos índices de emissões. Normalmente não se dispõe de tais informações provenientes dos fornecedores de injetores, o que obriga a utilização de uma bancada de spray para ensaiar a injeção nas mesmas condições encontradas no motor.

Para o trabalho em questão, a bancada foi utilizada para a caracterização dos injetores de aplicação PFI.
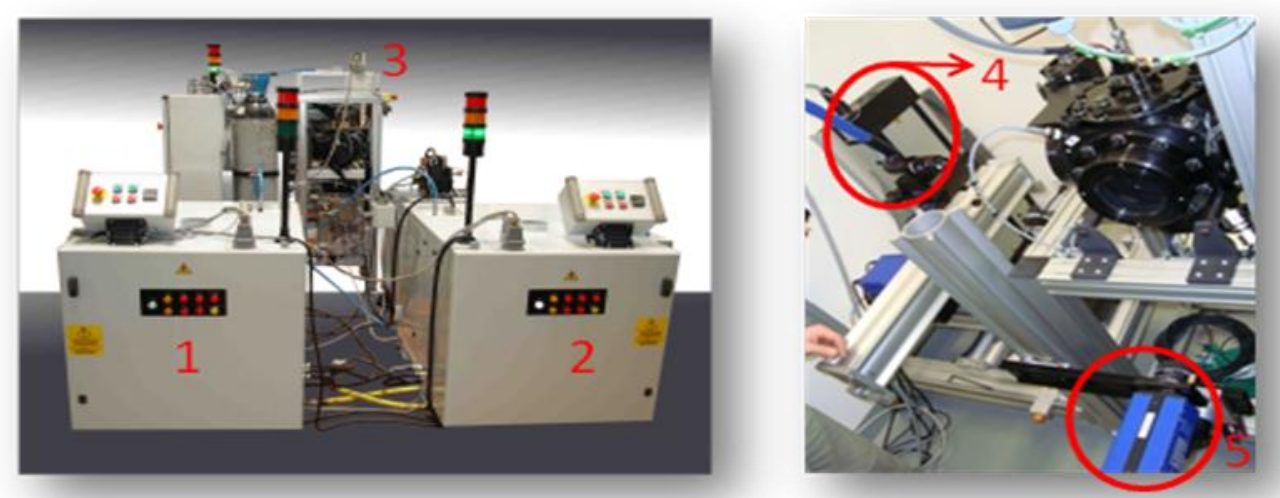

Figura 71 - Bancada de "spray”. 


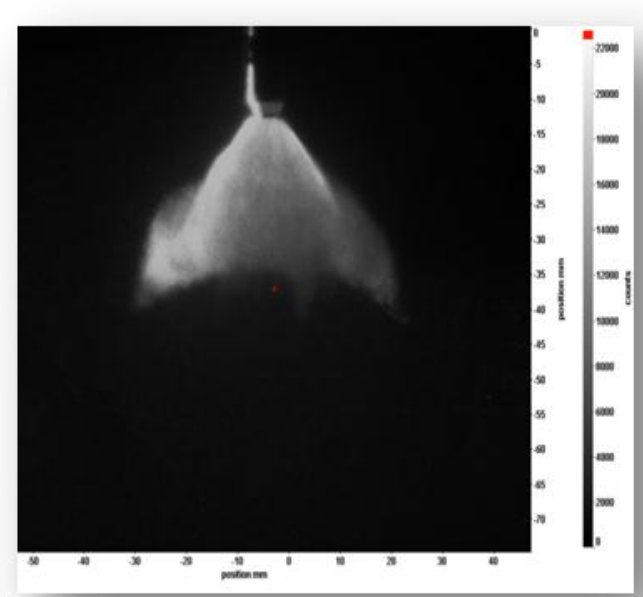

Figura 72 - Injeção de combustível.

A Figura 71 mostra o equipamento de caracterização de injetores: (1) e (2) bancos de armazenamento e bombeamento dos fluidos; (3) câmara de visualização; (4) laser; (5) câmera de alta velocidade CCD.

\subsubsection{Consumo de Combustível}

A forma considerada bem confiável para medida de consumo de combustível foi a encontrada no equipamento da "Metroval", cujo funcionamento se basea no princípio de Coriolis, conforme descrito por Balbinot (2007, vol. 2 - pág. 420).

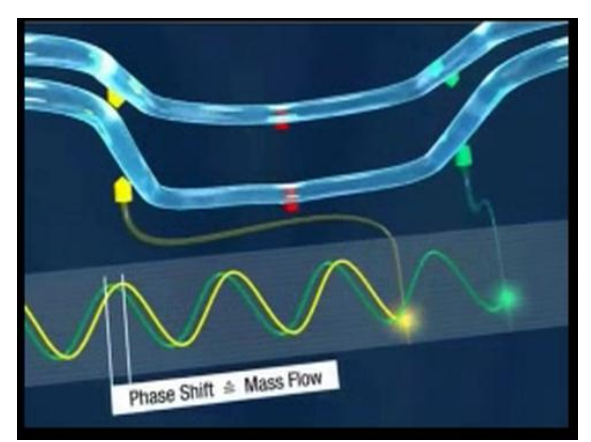

Figura 73 - Princípio de funcionamento. 


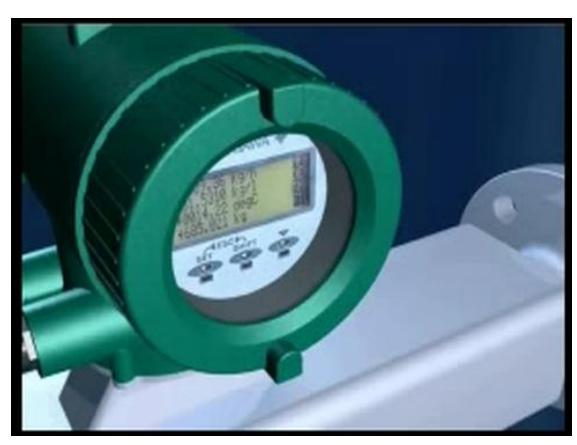

Figura 74 - Medidor de Fluxo. 


\section{FASE DE APRENDIZADO}

\subsection{SIMULAÇÃo DE FLUXO NÃO REATIVO E COMBUSTÃo PARA O CICLO OTTO}

Durante a fase de aprendizado, para uma ampla exploração dos graus de dificuldades dos modelos que envolvem malhas móveis, foram realizadas simulações com uma câmara de combustão do tipo "pent roof”, para a qual é necessário o uso das três técnicas: "smooth", "remeshing" e "leyering".

Abaixo, tem-se uma representação em corte, através de malha não estruturada, da câmara de combustão (tipo "pent roof”) de um motor de ignição por centelha e suas válvulas de admissão e descarga.

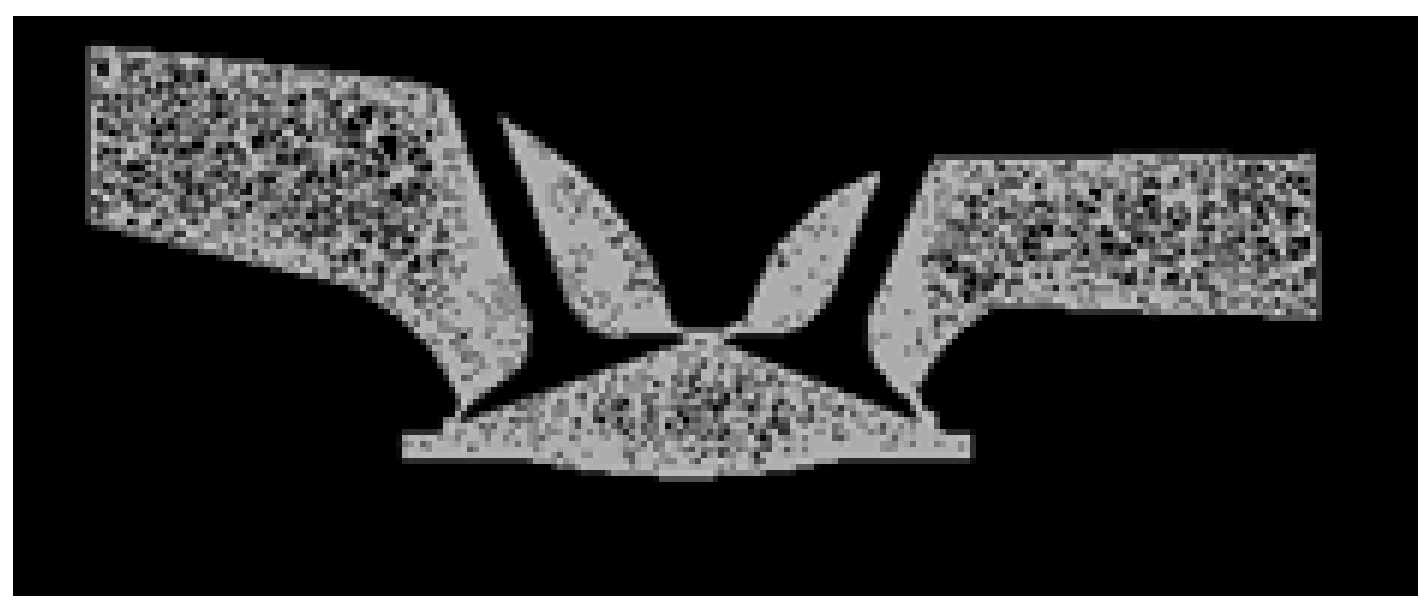

Figura 75 - Malha não estruturada. 
Na Figura 76 nota-se uma sequência que mostra a evolução da velocidade do fluxo de ar no interior do cilindro. Pode-se observar a formação de dois fluxos rotacionais em sentidos opostos, sendo um de maior intensidade (tumble).

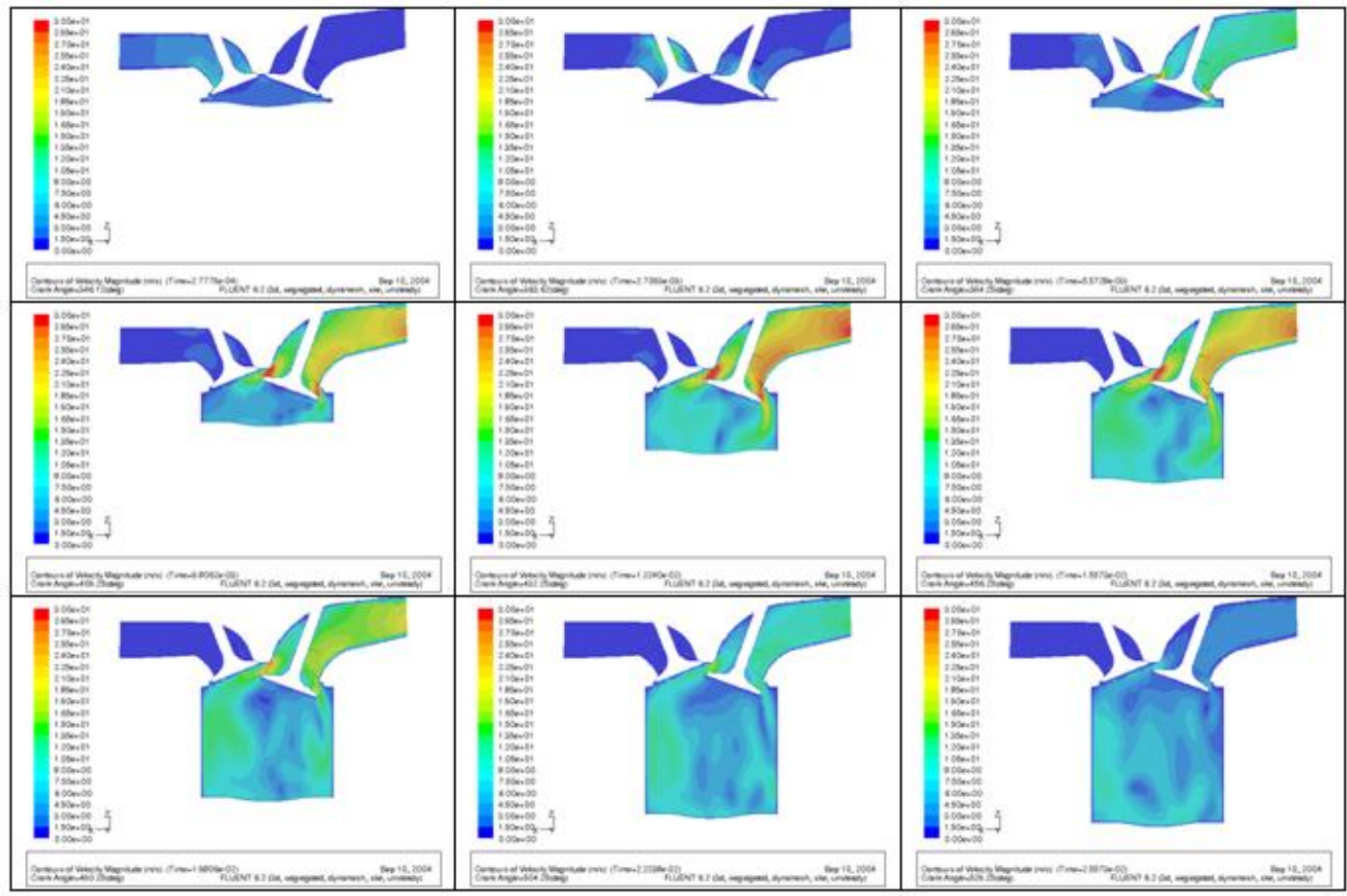

Figura 76 - Fluxo frio

A taxa de tumble em função do ângulo de manivelas é dada pela curva da Figura 77 (simulação): 


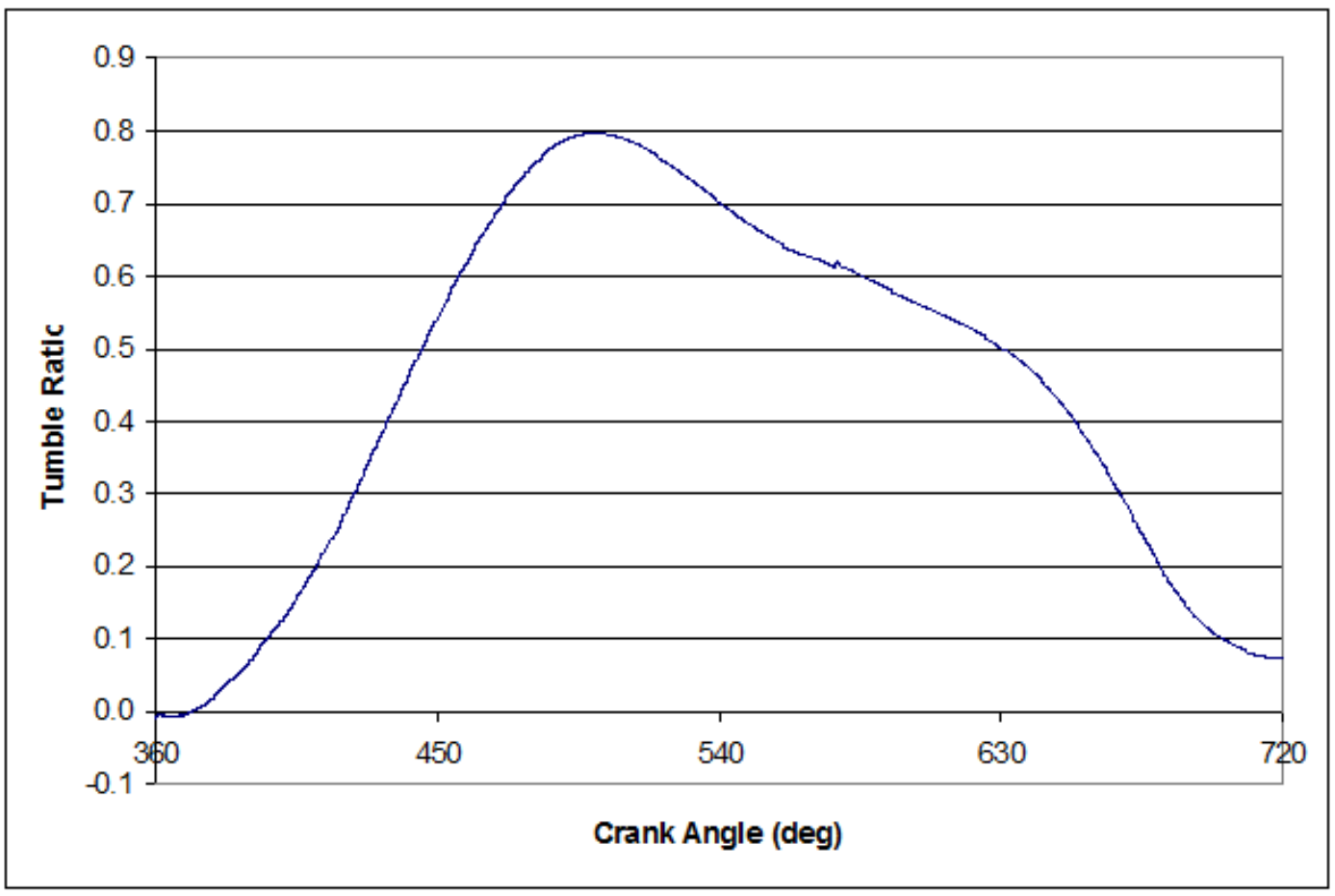

Figura 77 - Taxa de "Tumble". 
A Figura 78 evidencia como a velocidade de escoamento aumenta significativamente no início da abertura da válvula de admissão ao redor de sua face.

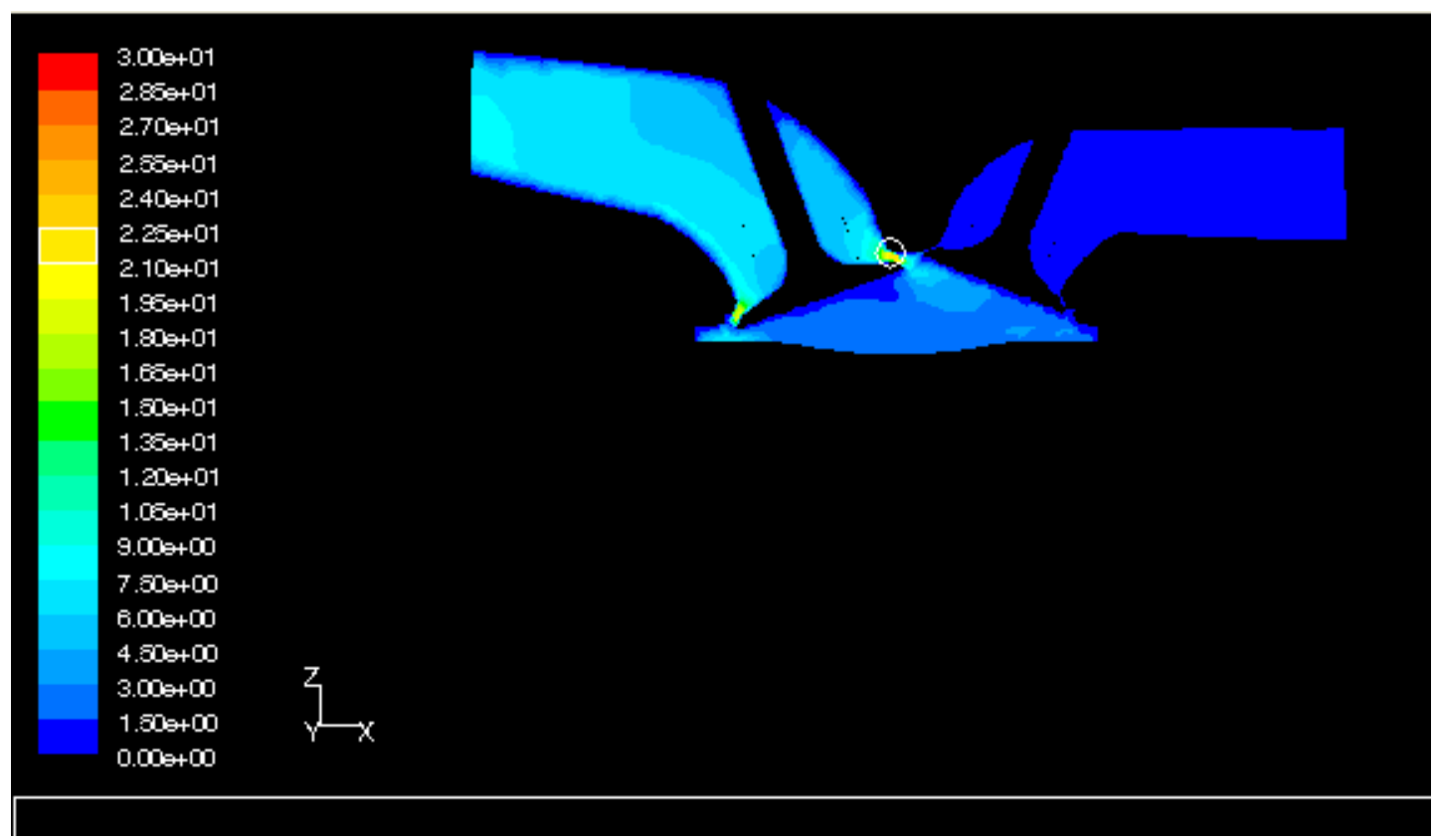

Figura 78 - Perfil de escoamento.

Na Figura 79, tem-se uma ilustração do perfil da evolução da temperatura no interior da câmara de combustão, mostrando o avanço da frente de chama. 


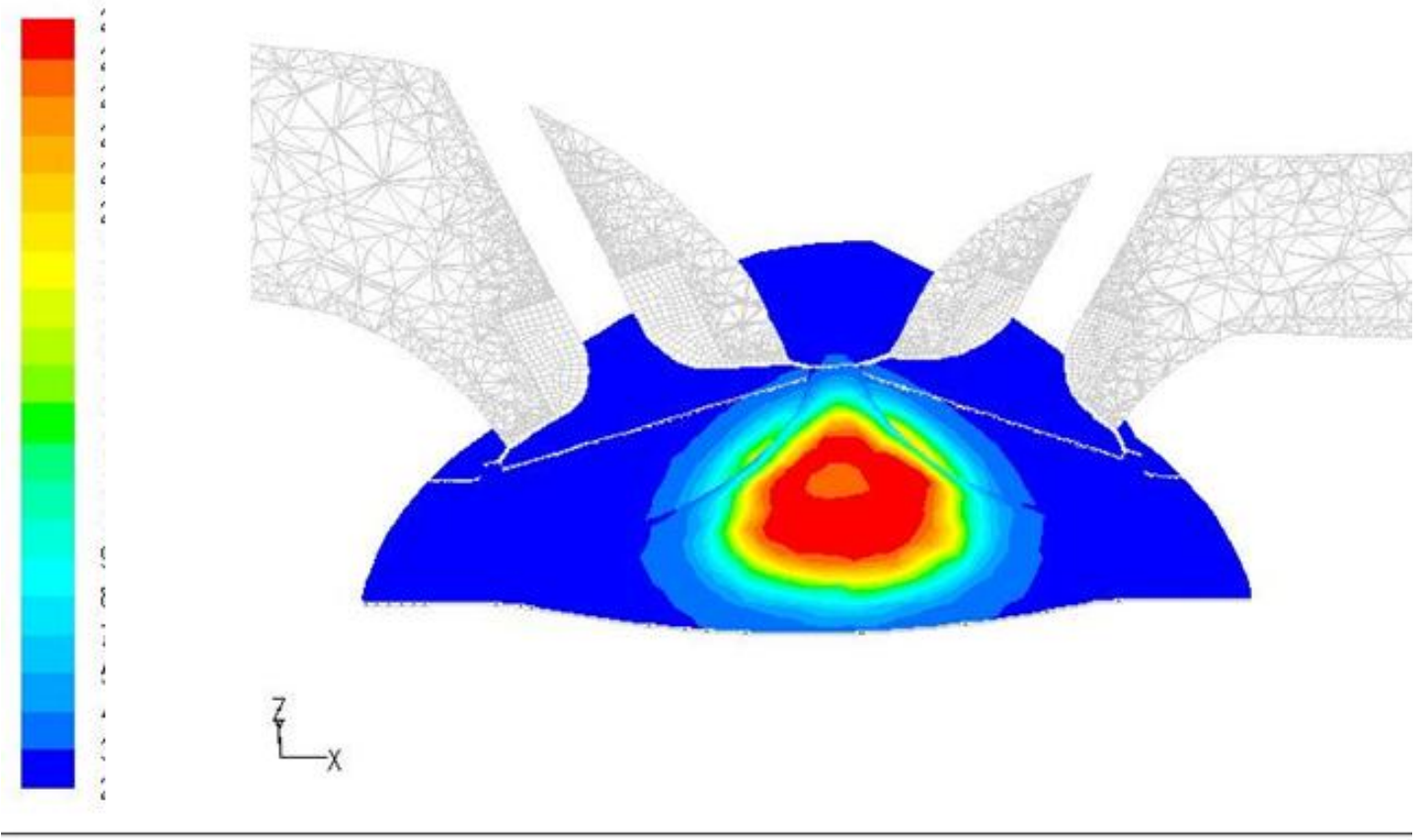

Contours of Static Temperature (k) (Time=6.9444e-04)

Mar 28, 2007 Crank Angle=717.25(deg) FLUENT 6.3 (3d, dp, pbns, dynamesh, ske, unsteady)

Figura 79 - Evolução da temperatura. 
A Figura 80 demonstra a evolução do processo reativo, sendo a parte vermelha relativa à reação completa e a azul, característica da mistura fresca. Notam-se processos intermediários da combustão.
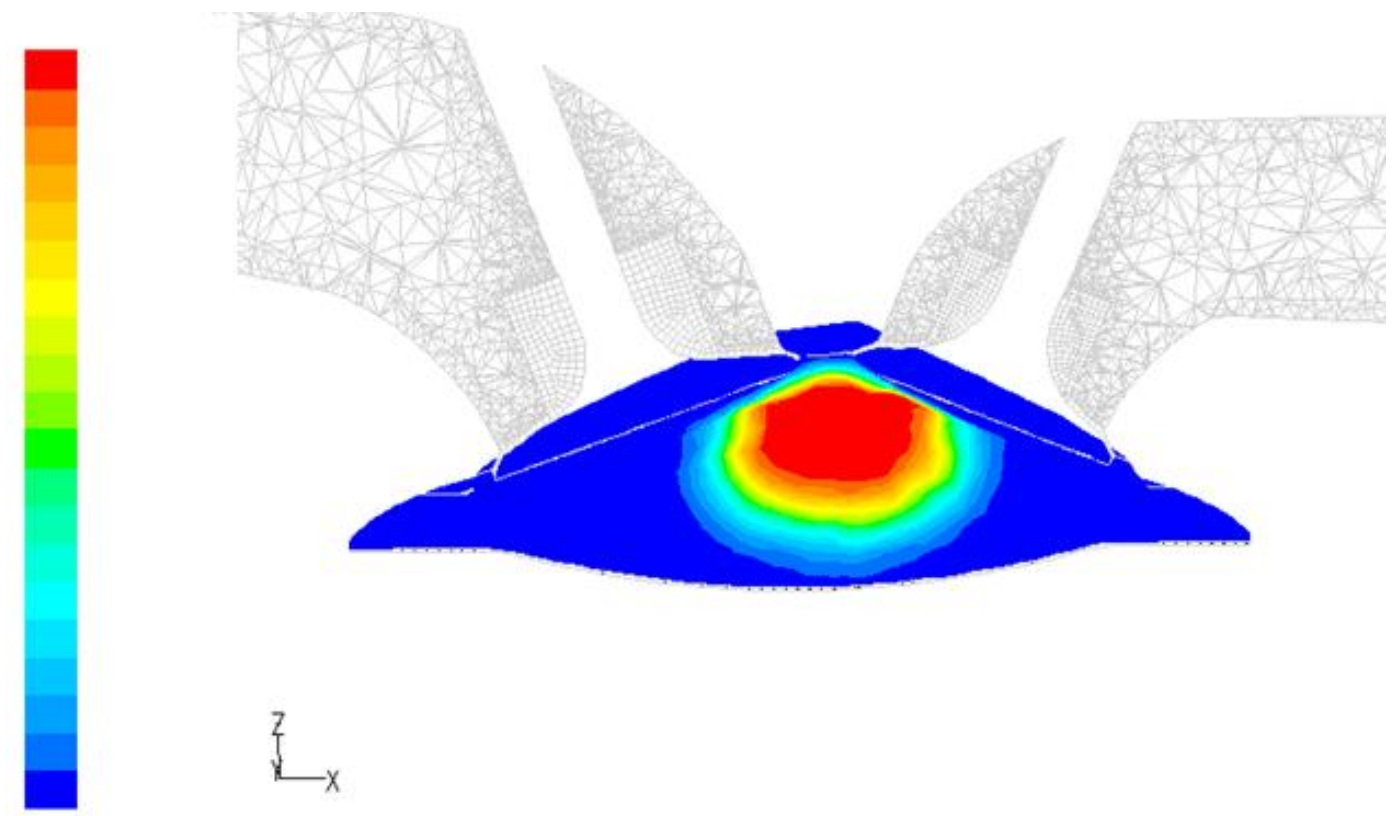

Contours of Progress Variable (Time $=6.9444 \mathrm{e}-04$ )

Mar 28, 2007 Crank Angle $=717.25$ (deg.

Figura 80 - Evolução da frente de chama.

A Figura 81 ilustra a taxa de formação de produtos, mostrando claramente a "espessura" da frente de chama, uma região altamente reativa. 


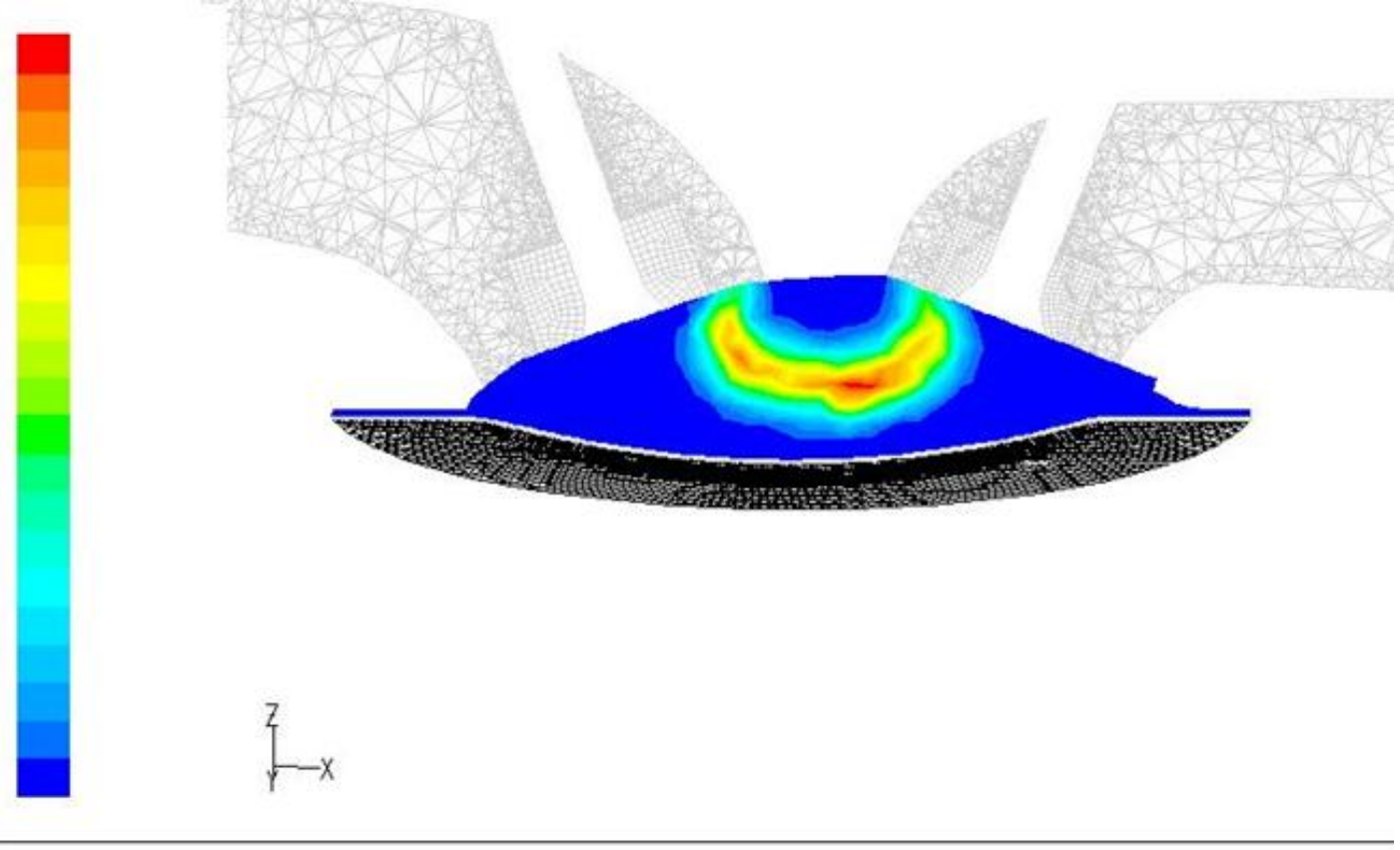

Contours of Product Formation Rate (1/s) (Time-6.9444e-04)

Mar 28, 2007

Crank Angle=717.25(deg)

FLUENT 6.3 (3d, dp. pbns, dynamesh, ske, unsteady)

Figura 81 - Formação de produtos. 
$\mathrm{Na}$ sequência, as figuras Figura 82 e Figura 83Figura 83 explicitam a liberação de calor acumulada no processo e a curva de pressão no cilindro, respectivamente.

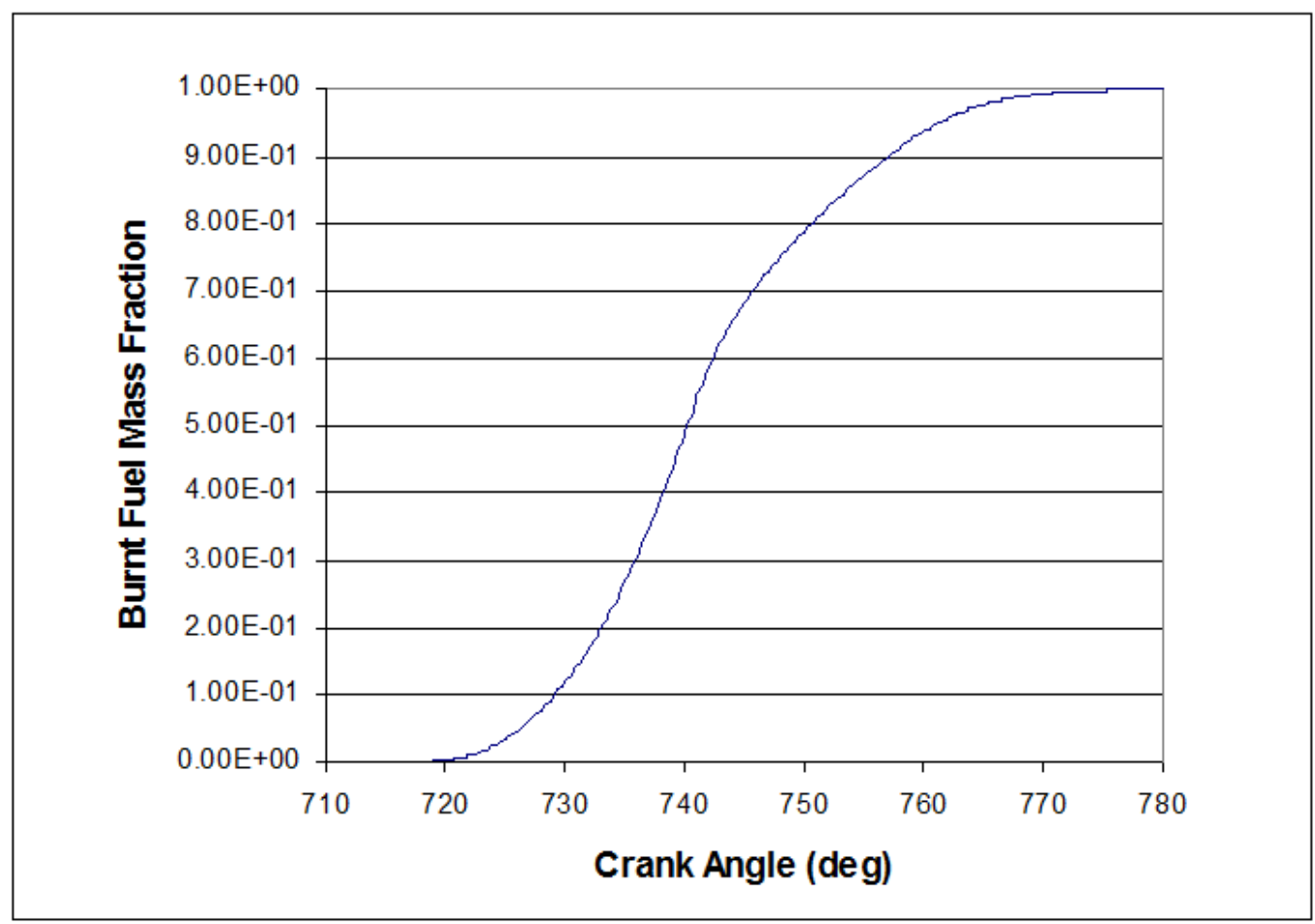

Figura 82 - Liberação de calor (acumulado). 


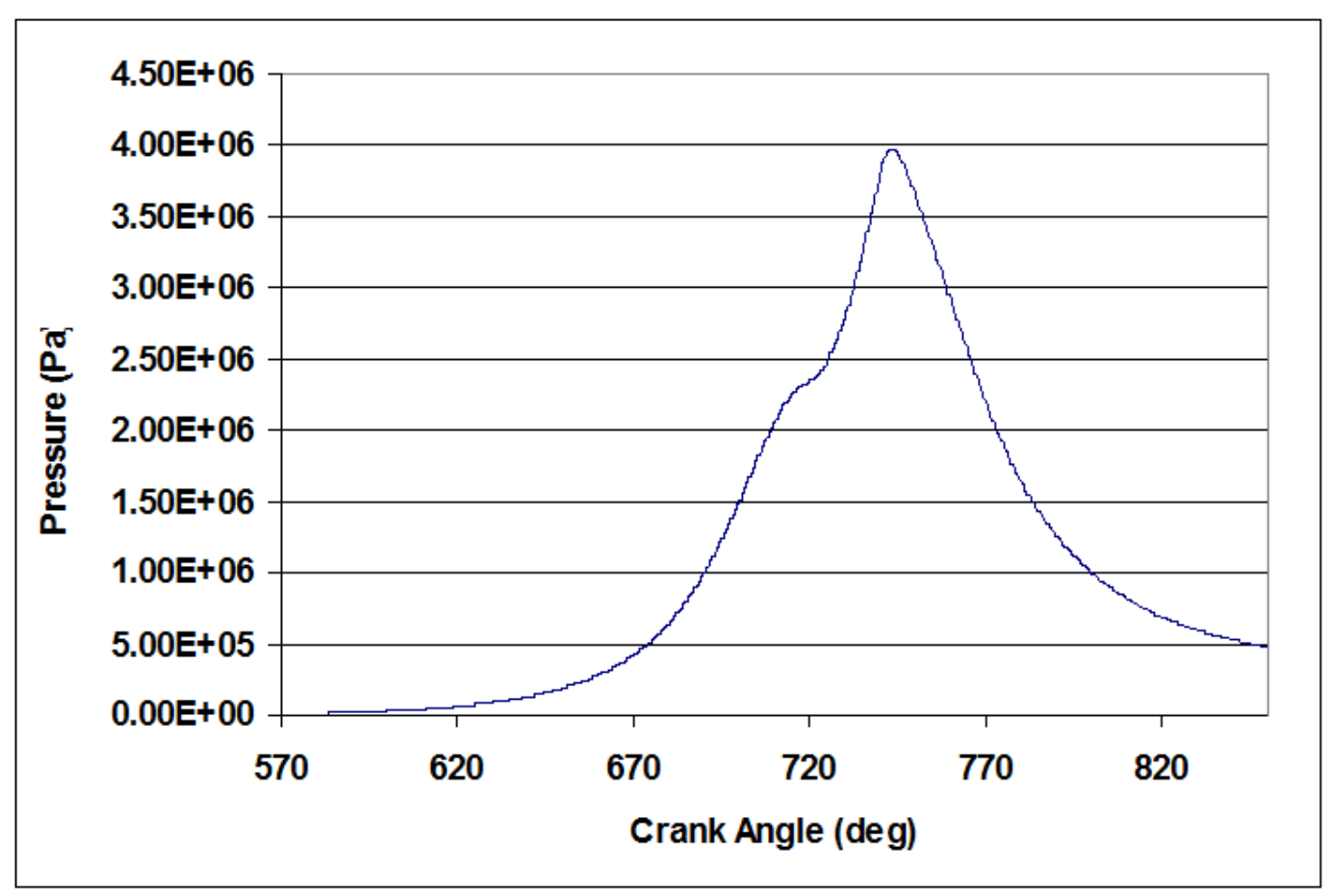

Figura 83 - Curva de pressão no cilindro.

\subsection{SIMULAÇÃO PARA O CICLO DIESEL}

Para esse trabalho, considerou-se um motor Diesel de injeção direta de combustível na câmara de combustão. O modelo de chama não pré-misturada utilizado foi o "Eddy Dissipation", com a proposição de resolver o problema tridimensional e transiente.

Para simplificação, esta simulação começou com a válvula de admissão fechada, no início da fase de compressão, e terminou quando a válvula de escapamento começa a abrir, ou seja, no final da fase de expansão. Apenas "layering" foi considerado para geração de malhas com fronteira móvel, conforme ilustrado na Figura 84 que contém apenas 2400 células tetraédricas, inicialmente. 


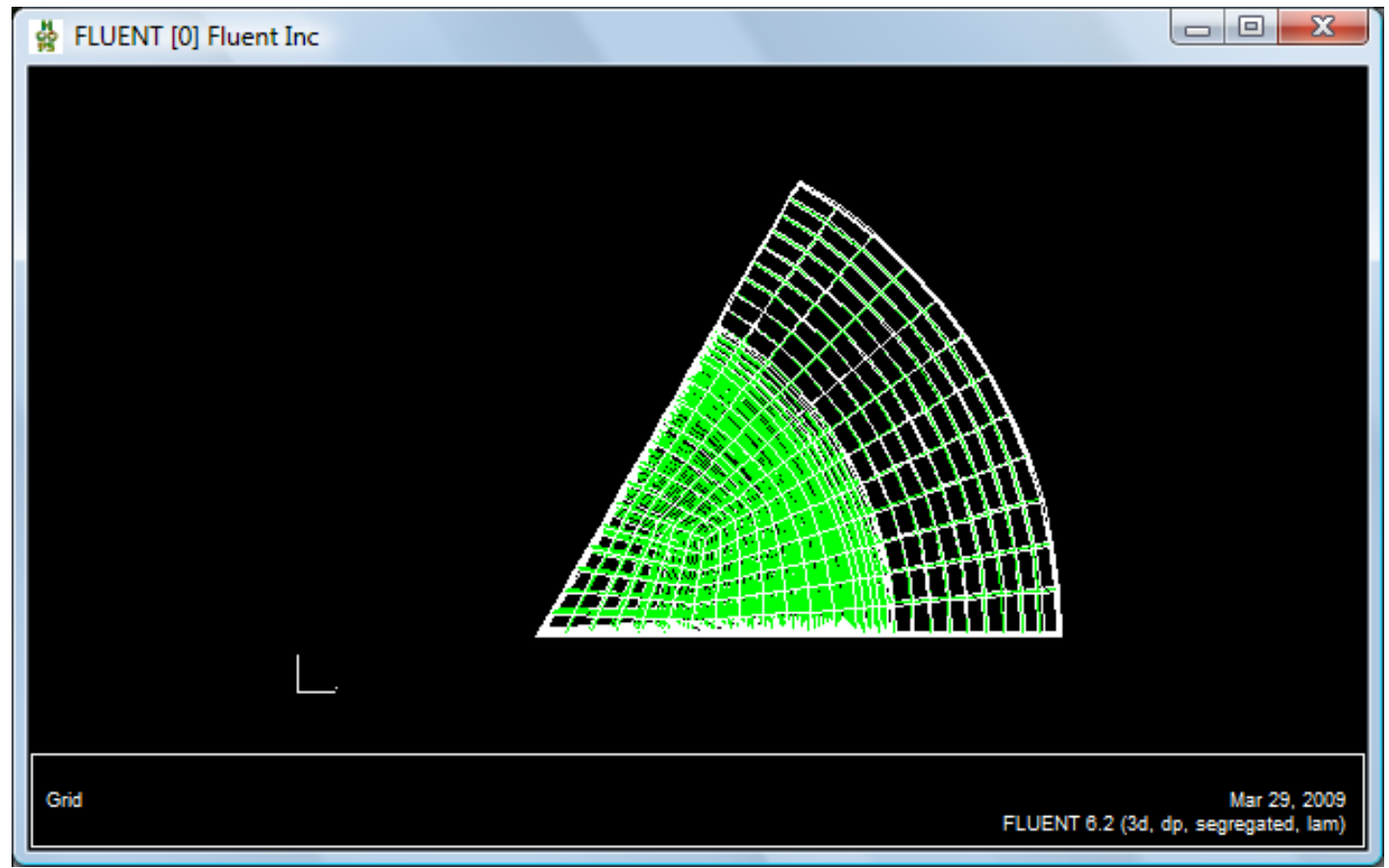

Figura 84 - Malhas computacionais

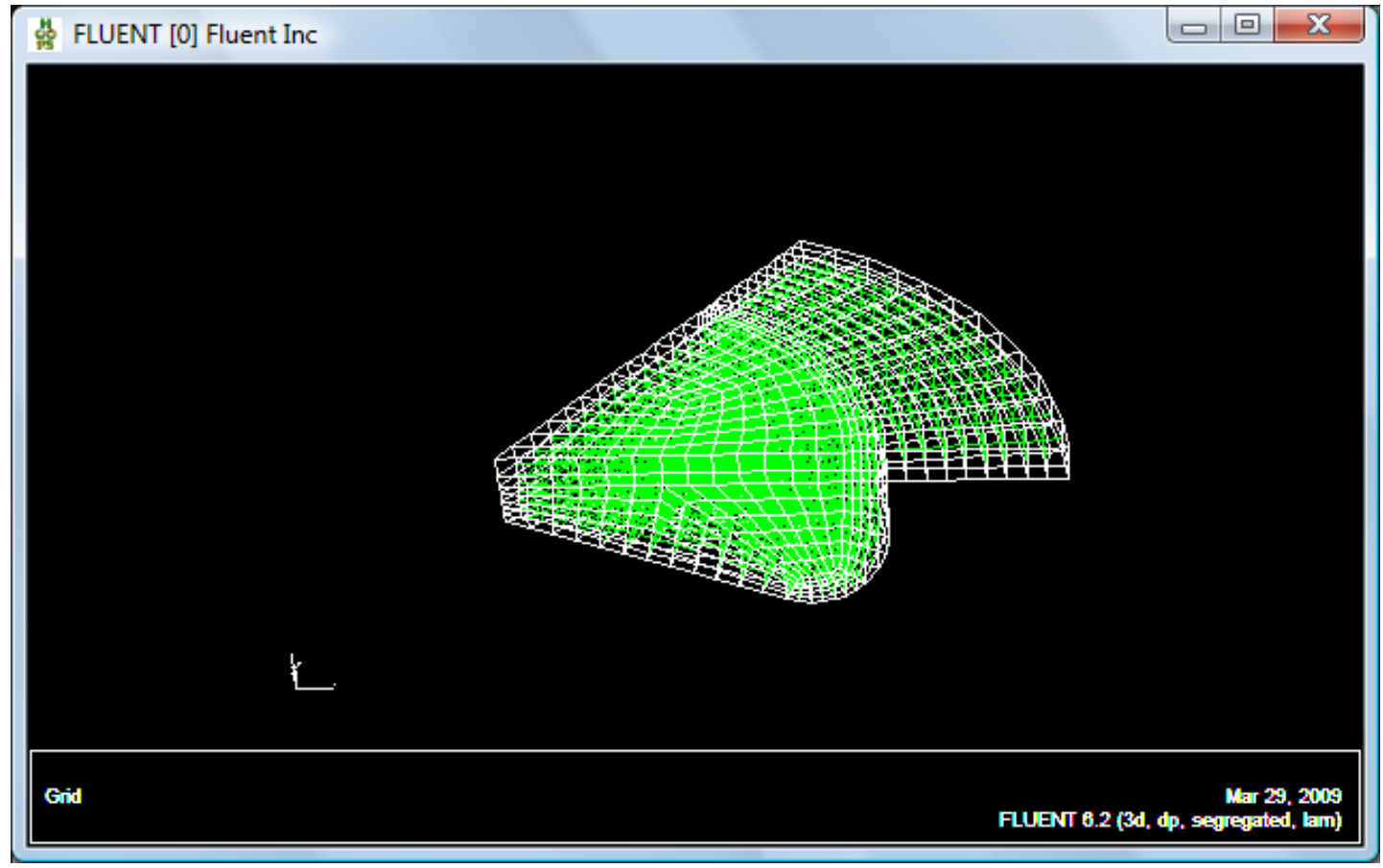

Figura 85 - Propriedade de simetria (ângulo de $60^{\circ}$ )

Pode-se observar que apenas $60^{\circ}$ de malha, correspondente à região de um único furo do injetor, foi gerada, (Figura 85) em função da propriedade de simetria do problema, em relação 
à qual o FLUENT permite análise para toda a extensão de $360^{\circ}$ através de um recurso de fronteiras periódicas.

Ao se definirem os parâmetros de fronteira móvel no Fluent, tem-se a opção "incylinder”, que permite determinar a rotação do motor, ângulo de virabrequim do início e fim do processo de simulação, como ângulo de "time step", também curso do pistão e comprimento de biela, responsáveis pela forma em que as novas células serão geradas durante o "layering".

Para que se tenha mais precisão durante os processos reativos, adotou-se dividir todo o processo em eventos não reativos e reativos, onde os "times steps" correspondentes eram respectivamente, equivalentes a $0.2^{\circ}$ e $0.1^{\circ}$ do virabrequim. Isso permitiu otimizar o tempo de processamento total do processo.

Como a fase de admissão de ar foi desconsiderada nessa simulação, efeitos dinâmicos como "swirl", por exemplo, foram suprimidos dessa simulação, no entanto, uma taxa de "swirl" igual a 2 foi introduzida de forma virtual, considerando-se inicialmente todo o fluido no interior do cilindro como se fosse um corpo rígido girando em torno do eixo $\mathrm{Z}$.

O modelo de turbulência k-epsilon também foi utilizado nessa simulação;

Diferentemente do ciclo Otto que inicia o processo de combustão em um ou mais pontos fixos através de uma centelha, no ciclo Diesel é preciso utilizar um modelo de autoignição que, no FLUENT, é chamado "Ignition Delay Model”, com o qual é possível alterar a energia de ativação, por exemplo.

Quanto à injeção de combustível, adotou-se a forma de cone sólido com os seguintes parâmetros: 
Tabela 1 - Parâmetros de injeção

\begin{tabular}{|l|l|}
\hline X-Position & 0.0197 \\
\hline Y-Position & 0.00984 \\
\hline Z-Position & 6.98 \\
\hline Diameter (in) & 0.01 \\
\hline Temperature (k) & 341 \\
\hline Start Time (s) & 0.01489 \\
\hline Stop Time (s) & 0.01708 \\
\hline X-Axis & 0.866 \\
\hline Y-Axis & 0.5 \\
\hline Z-Axis & -0.4617 \\
\hline Velocity Mag. (m/s) & 468 \\
\hline Cone Angle (deg) & 8 \\
\hline Radius (in) & 0 \\
\hline Total Flow Rate (kg/s) & 0.00807 \\
\hline
\end{tabular}

Outra etapa importante foi a definição dos métodos de discretização para as soluções das equações diferenciais que representam o problema em questão. Métodos como "Upwind" e PISO (acoplamento pressão-velocidade) foram utilizados.

Para o controle de iterações, verificou-se um bom compromisso para 50 iterações por “Time Step", sendo um total de 1675 "steps".

A substância em questão foi o óleo diesel, representado pela fórmula $\mathrm{C}_{16} \mathrm{H}_{29}$.

A Figura 86 ilustra o perfil de velocidades tangenciais no interior do cilindro, mostrando claramente a influência da imposição de um "swirl” inicial, e a Figura 87 evidencia o perfil de velocidades radiais, onde pode ser observada a injeção de combustível na base do pistão. 


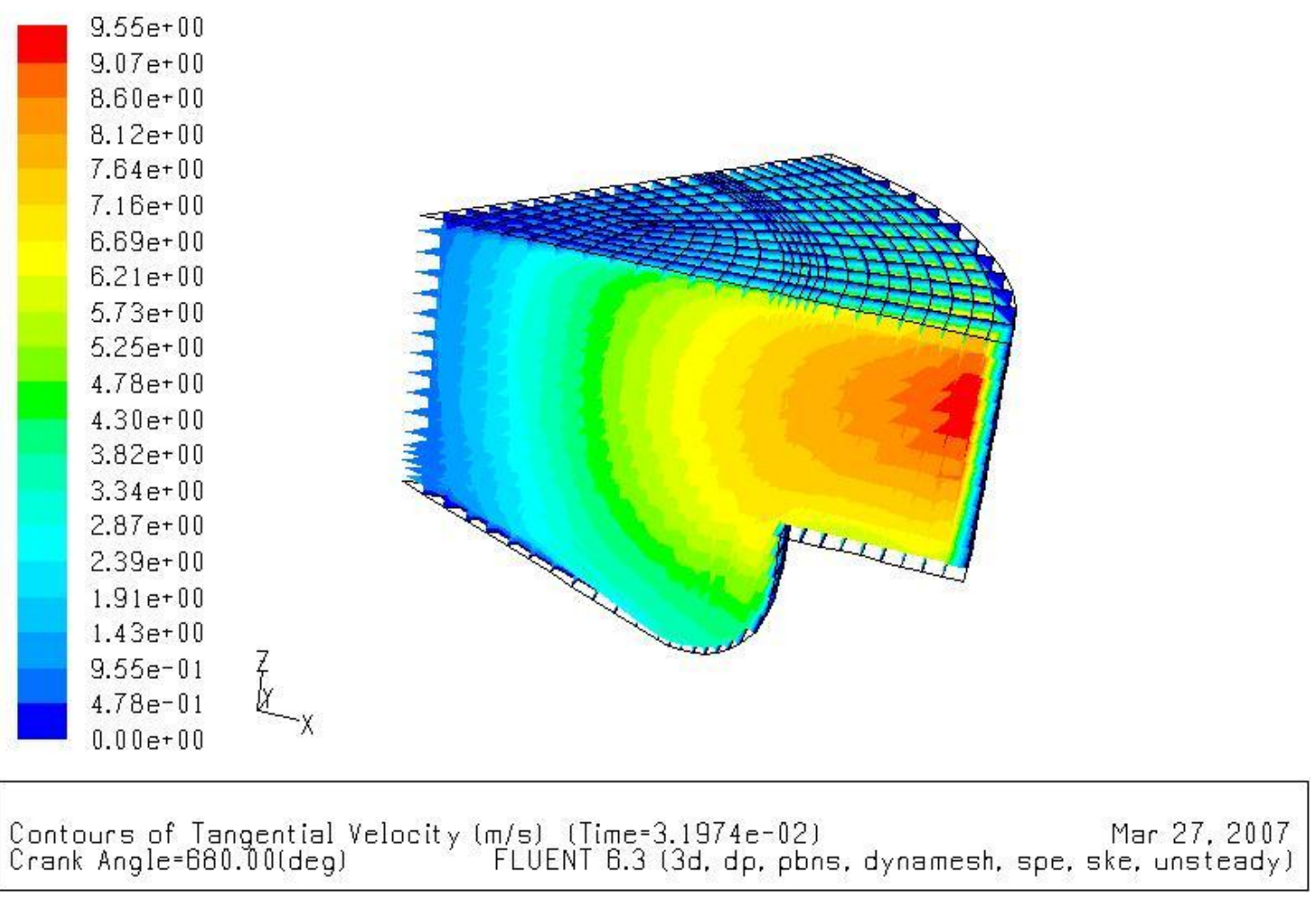

Figura 86 - Perfil de velocidade tangencial.
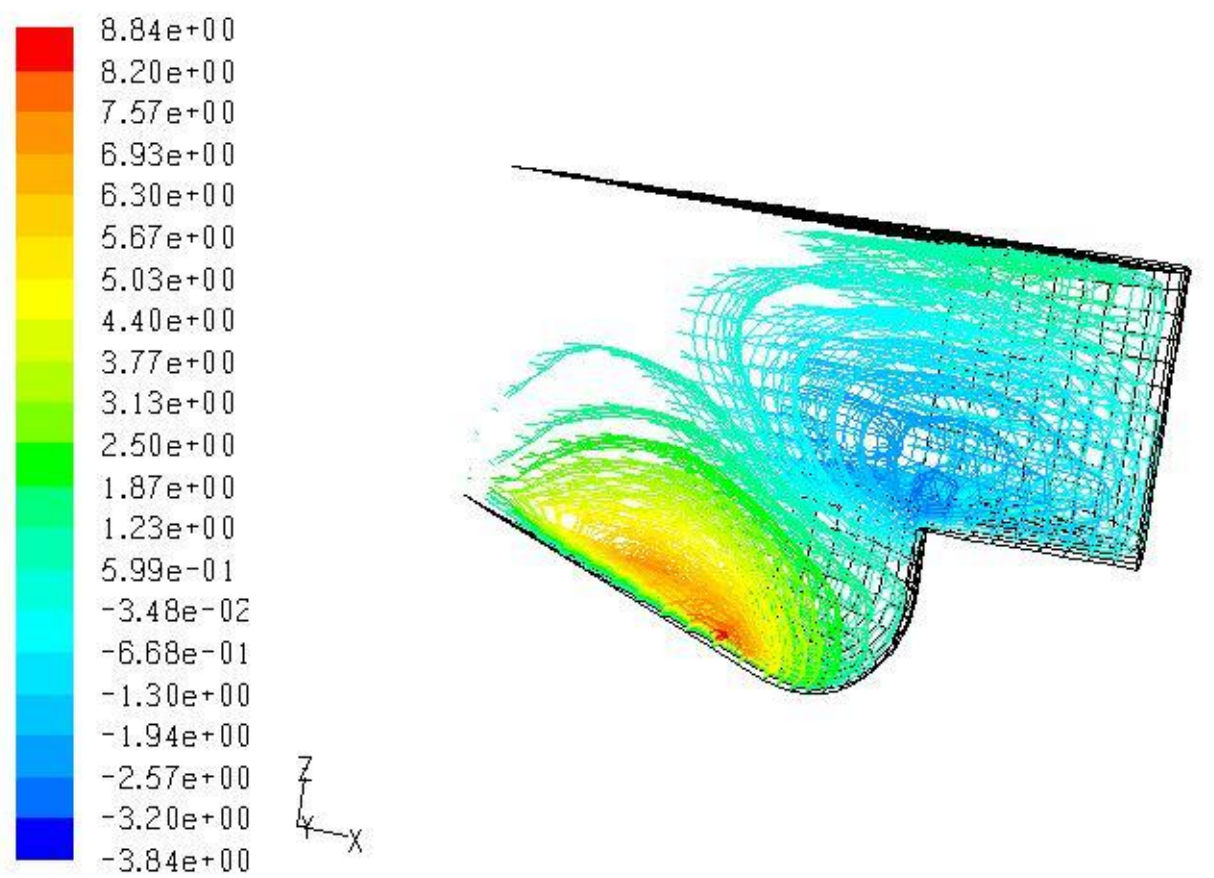

Contours of Radial Velocity (m/s) (Time $=3.1974 \mathrm{e}-02$ )

Mar 27,2007

Crank Angle $=680.00$ (deg) FLUENT $\dot{6} .3$ (3d, dp, pbns, dynamesh, spe, ske, unsteady)

Figura 87 - Perfil de velocidade radial. 
O perfil de temperatura na face do pistão é mostrado na Figura 88, o que está relacionado com a liberação de calor da combustão.

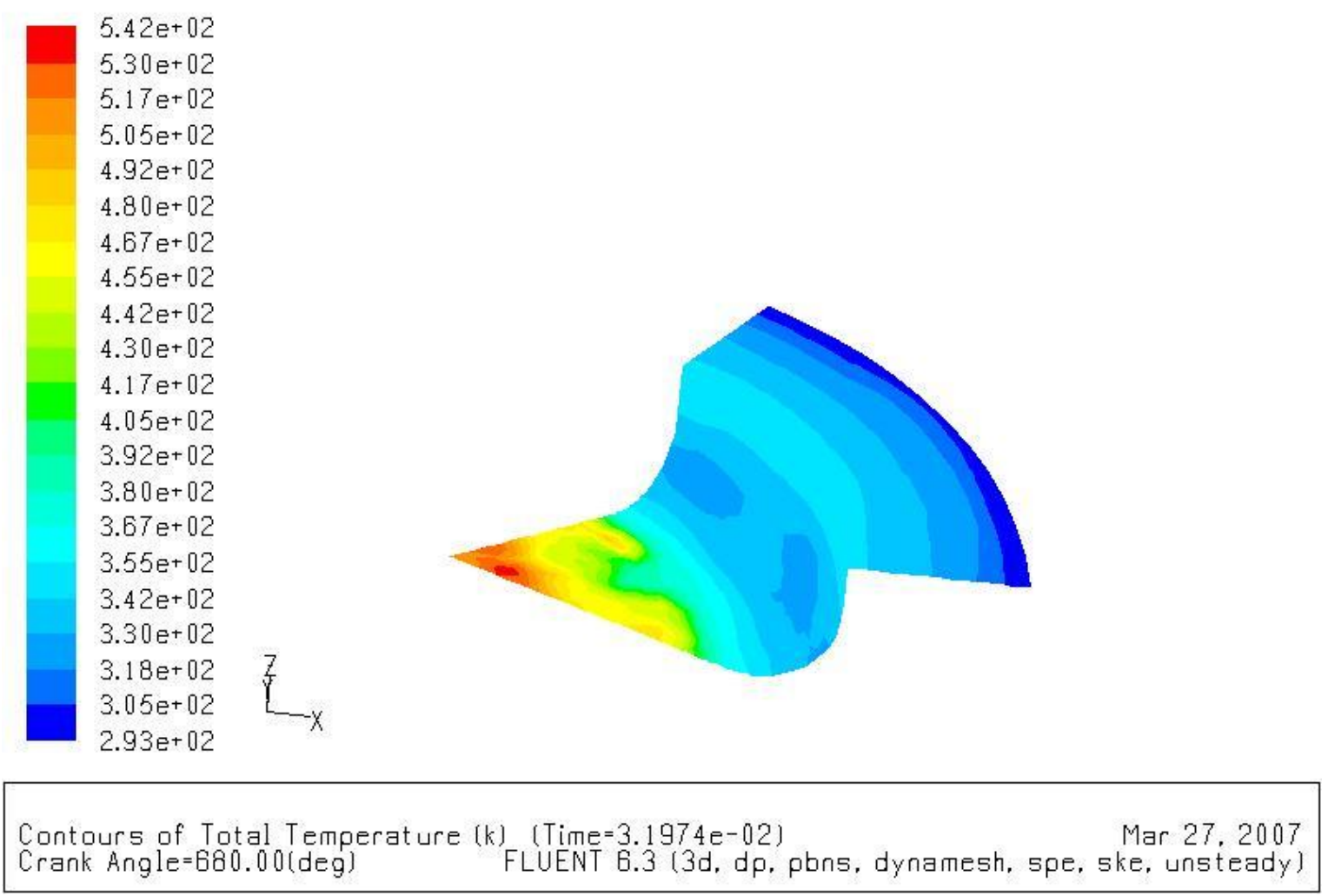

Figura 88 - Perfil de temperatura total.

O perfil de energia cinética turbulenta é mostrado na Figura 89. Podem-se observar altos níveis na região do spray de combustível e região de encontro da cavidade do pistão (bowl) e área de compressão (squish), como era de se esperar. 


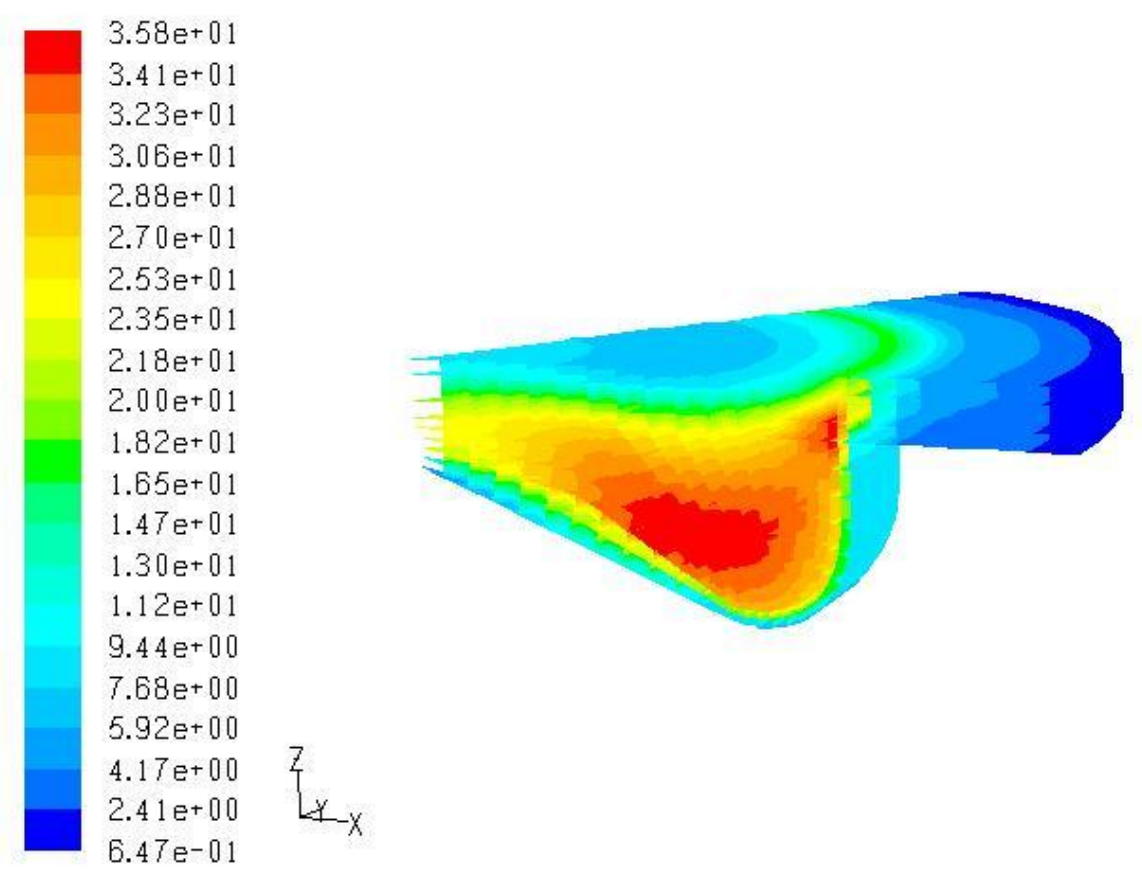

Contours of Turbulent Kinetic Energy ( $k$ ) (m2/s2) (Time=3.6970 e-02)

Uma observação interessante é a da Figura 90, que mostra o perfil de temperatura na parede do cilindro e face da câmara de combustão, revelando gradientes de temperaturas que podem levar à fadiga de material. 
$2.36 e+03$

$2.31 e+03$

$2.26 e+03$

$2.21 \mathrm{e}+03$

$2.17 e+03$

$2.12 \mathrm{e}+03$

$2.07 e+03$

$2.03 e+03$

$1.98 e+03$

$1.93 e+03$

$1.89 e+03$

$1.84 \mathrm{e}+03$

$1.79 e+03$

$1.75 e+03$

$1.70 \mathrm{e}+03$

$1.65 e+03$

$1.60 e+03$

$1.56 \mathrm{e}+03$

$1.51 \mathrm{e}+03$

$1.46 e+03$

$1.42 \mathrm{e}+03$

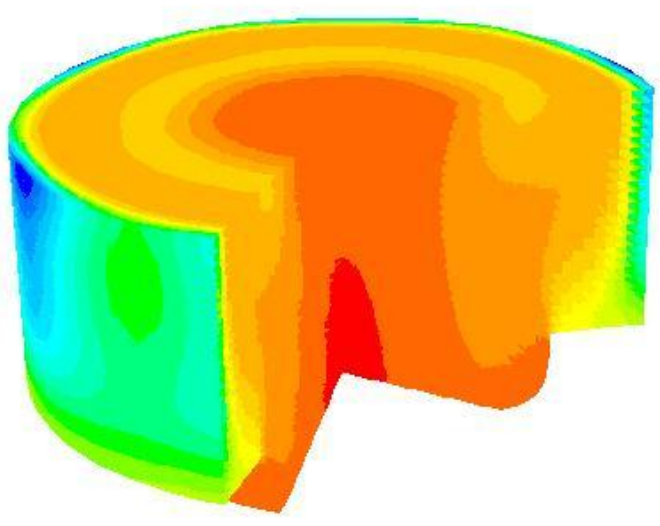

Contours of Static Temperature (k) (Time=4.1966e-02)

Mar 27, 2007 Crank Angle $=780.00$ (deg) FLUENT 6.3 (3d, dp, pbns, dynamesh, spe, ske, unsteady)

Figura 90 - Perfil de temperatura estática. 


\section{FASE DE DESENVOLVIMENTO}

\subsection{DESENVOLVIMENTO DA CÂMARA DE COMBUSTÃo}

\subsubsection{Simulação de Escoamento Não Reativo}

O primeiro critério adotado foi investigar o efeito da geometria da câmara de combustão na estrutura de fluxo e grandezas como energia cinética turbulenta, e entender como isso afeta a taxa de queima. Dessa forma, pode-se simular inicialmente apenas o escoamento não reativo. Para uma primeira comparação do modelo utilizado com dados experimentais, foi analisado o perfil de escoamento no interior do cilindro em uma secção transversal medida por meio de técnica PIV, e conforme ilustrado na Figura 91, é perfeitamente aceitável o caráter preditivo de tal modelo para escoamentos não reativos.

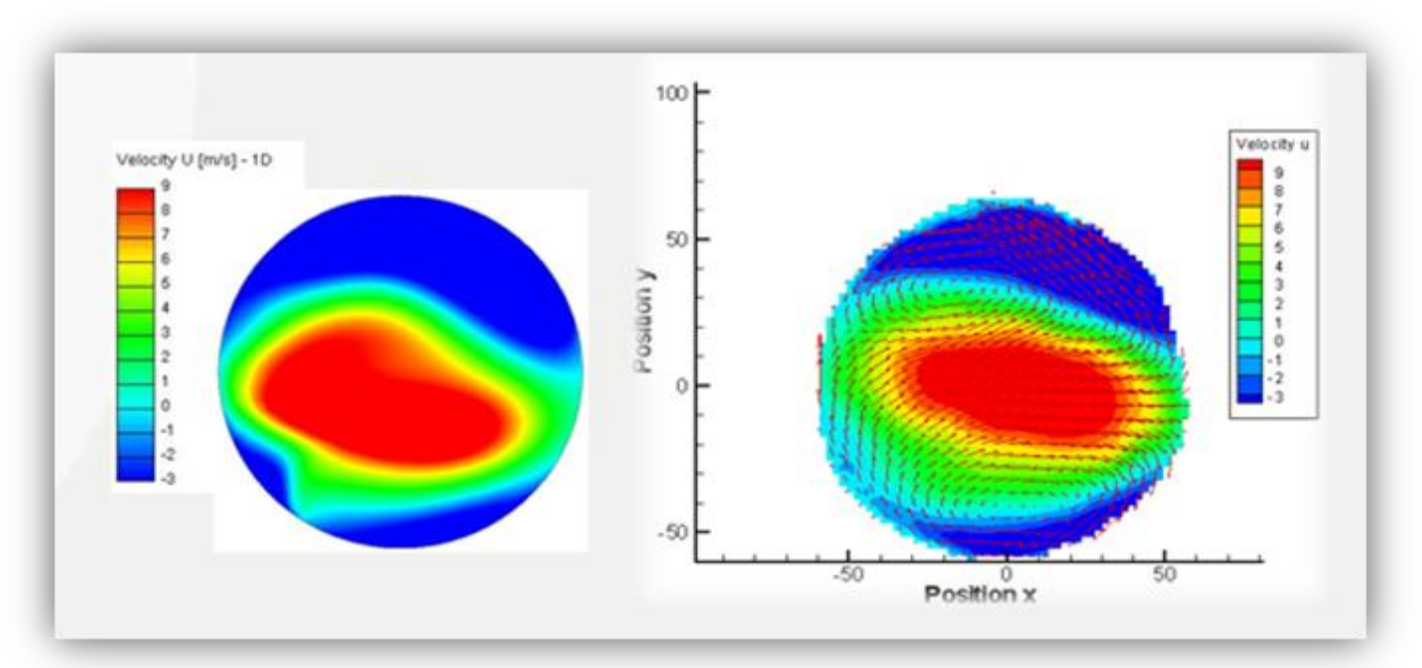

Figura 91 - Simulação x Experimental 
Como o desenvolvimento é focado em um motor de cabeçote plano, a geometria da câmara de combustão fica em sua maior parte na cavidade no pistão, sendo o volume da região de "squish" uma parcela menos significativa, mas que deve ser observada com critério.

A Figura 92 ilustra as primeiras propostas de geometrias simuladas, tendo como referência (baseline) a câmara cuja cavidade é plana em sua base, muito conhecida como “banheira no pistão", que é a configuração adotada no motor FEV (experimental).

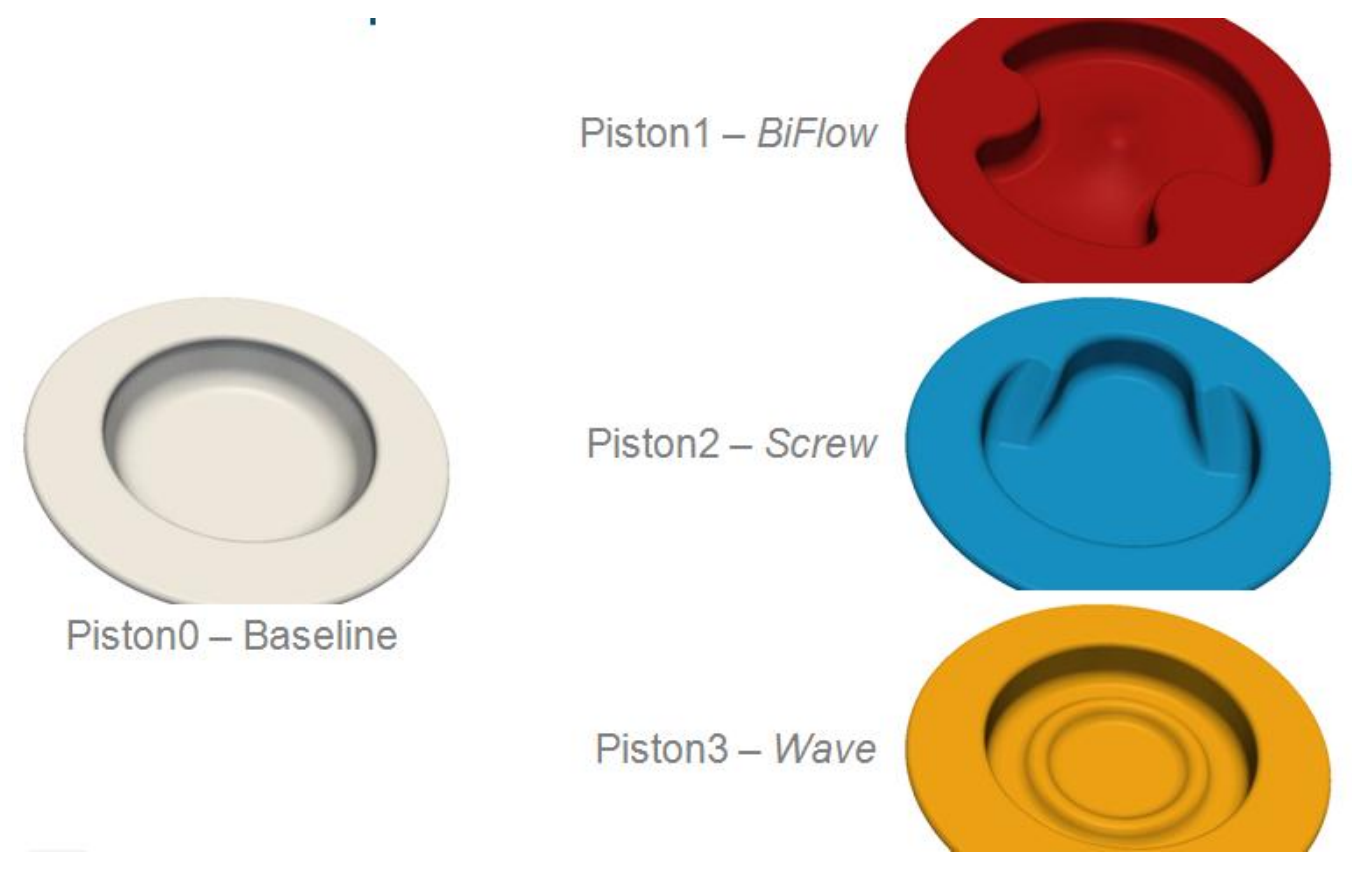

Figura 92 - Geometrias propostas.

Utilizando-se a estrutura de fluxo do cabeçote FEV, e simulando o escoamento do ar para o interior do cilindro, é possível comparar as energias cinéticas turbulentas, conforme ilustrado na Figura 93. 
TKE $[\mathrm{m} 2 / \mathrm{s} 2]$

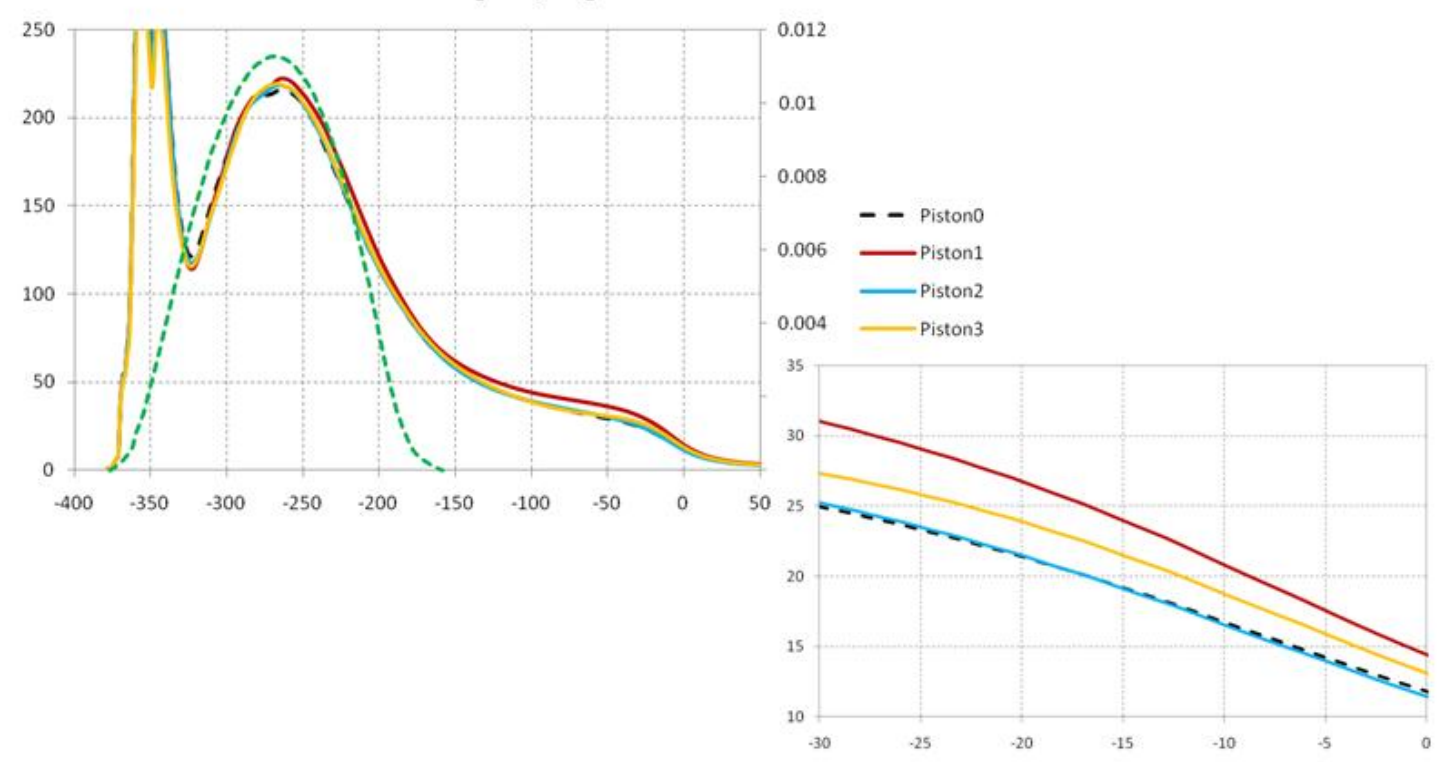

Figura 93 - Energia cinética turbulenta.

Observa-se que a energia cinética turbulenta é fortemente influenciada pelo movimento de abertura e fechamento da válvula de admissão (tracejado verde), tendo sua máxima magnitude coincidente com o ponto de abertura total da mesma.

O efeito da geometria da câmara de combustão só é representativo na fase de compressão, e embora de menor magnitude que durante a fase de admissão, é extremamente importante para a fase inicial da combustão.

Neste comparativo, a geometria da câmara com o pistão 1 (Biflow) se destaca em termos de energia cinética turbulenta no momento do disparo da centelha, que se dará a 25 graus APMS.

A seguir, é possível notar nas comparações visuais entre a câmara de referência (baseline) e as outras propostas, as distribuições dos perfis de energias cinéticas turbulentas próximos à vela de ignição (figuras Figura 94 eFigura 95). 


\section{Energia Cinética Turbulenta (Piston1 BiFlow)}

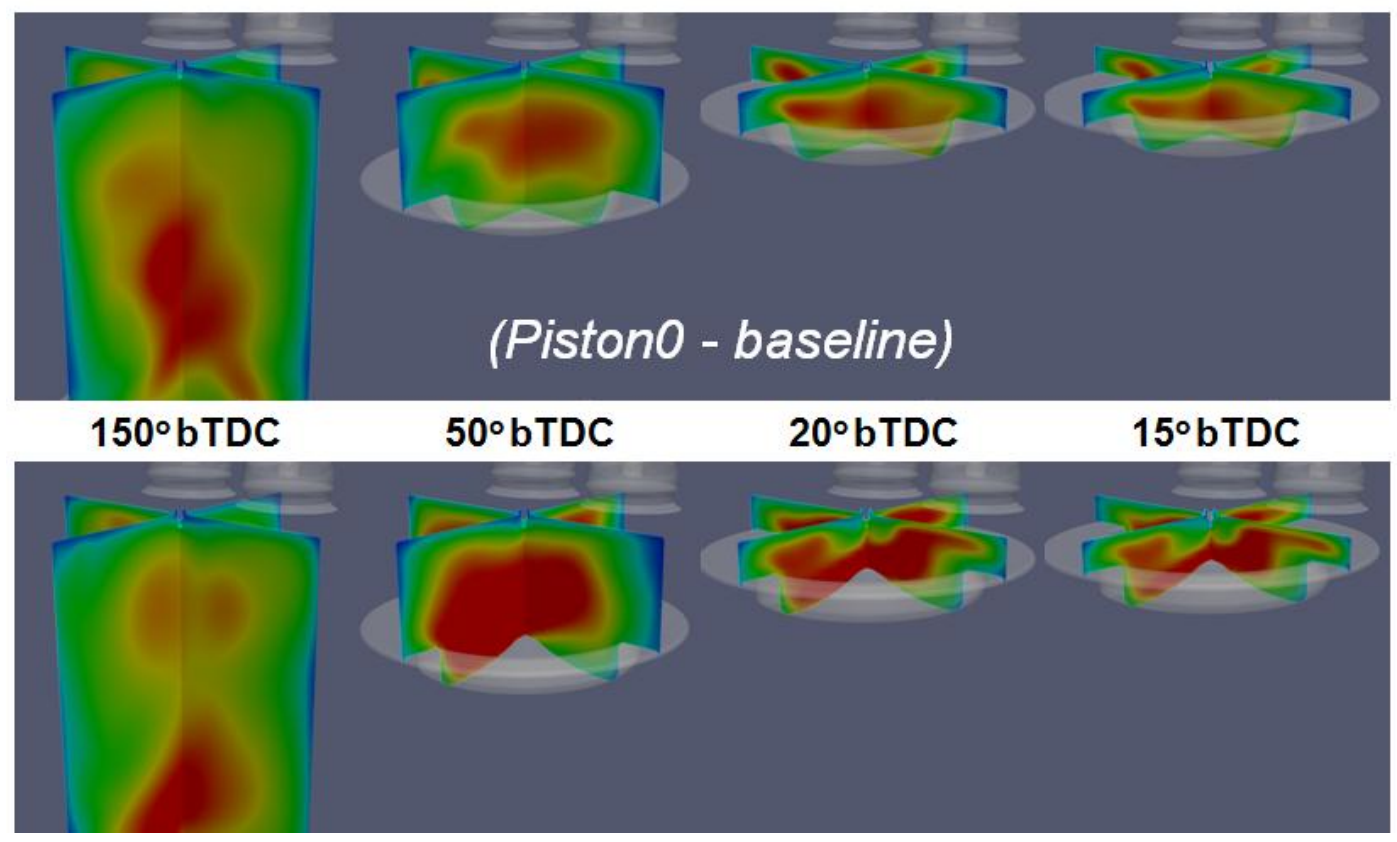

Figura 94 - Comparativo Biflow e Beseline (TKE).

\section{Energia Cinética Turbulenta (Piston2 Screw)}

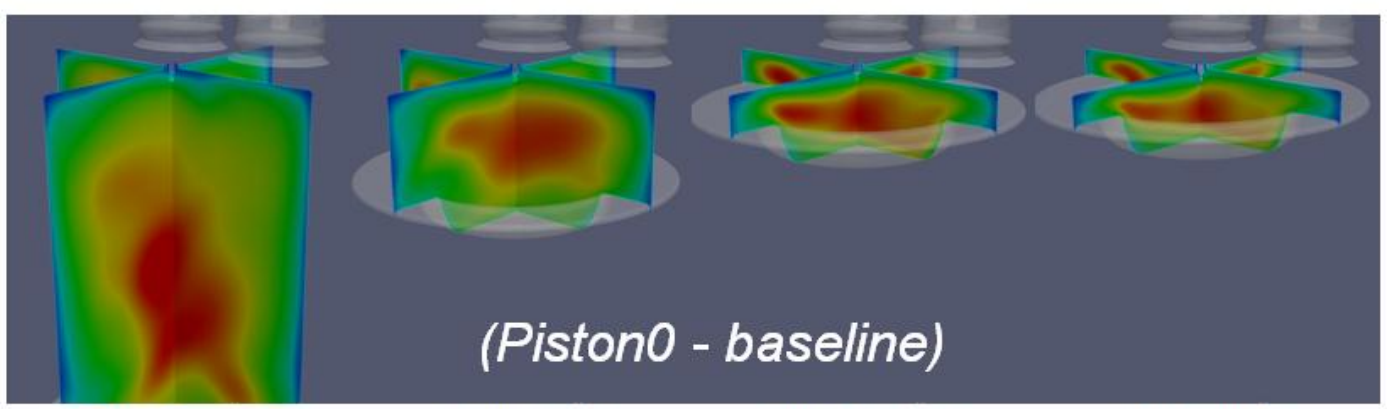

$150^{\circ} \mathrm{bTDC}$ $50^{\circ} \mathrm{bTDC}$ $20^{\circ} \mathrm{bTDC}$

$15^{\circ} \mathrm{bTDC}$

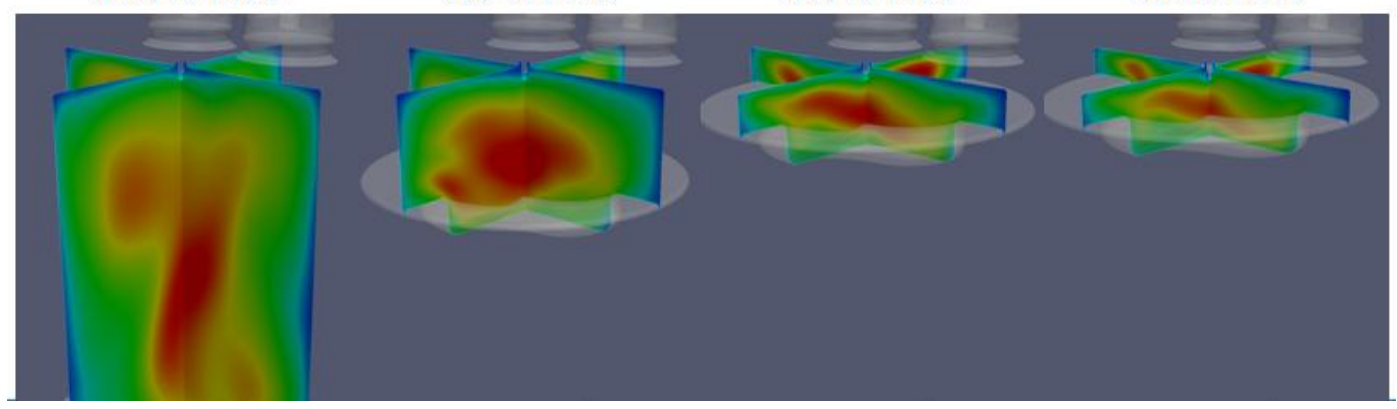

Figura 95 - Comparativo Screw e Baseline (TKE).

Embora o pistão 1 tenha se mostrado interessante do ponto de vista da magnitude da energia cinética turbulenta gerada, sua menor distribuição no entorno da vela de ignição não 
parece tão adequada. Isso pode ter ocorrido por conta dos ressaltos construídos para a quebra das macroestruturas ("swirl") em menores vórtices de turbulência na fase finas de compressão.

Outras duas propostas são representadas na Figura 96, onde o ressalto central do pistão 5 sugere o redirecionamento das microestruturas turbulentas para a vela de ignição, ainda que sem a intensa quebra das macroestruturas propostas pelo pistão 1; por outro lado, e o pistão 6 propõe quebras mais sutis dessas estruturas turbulentas.

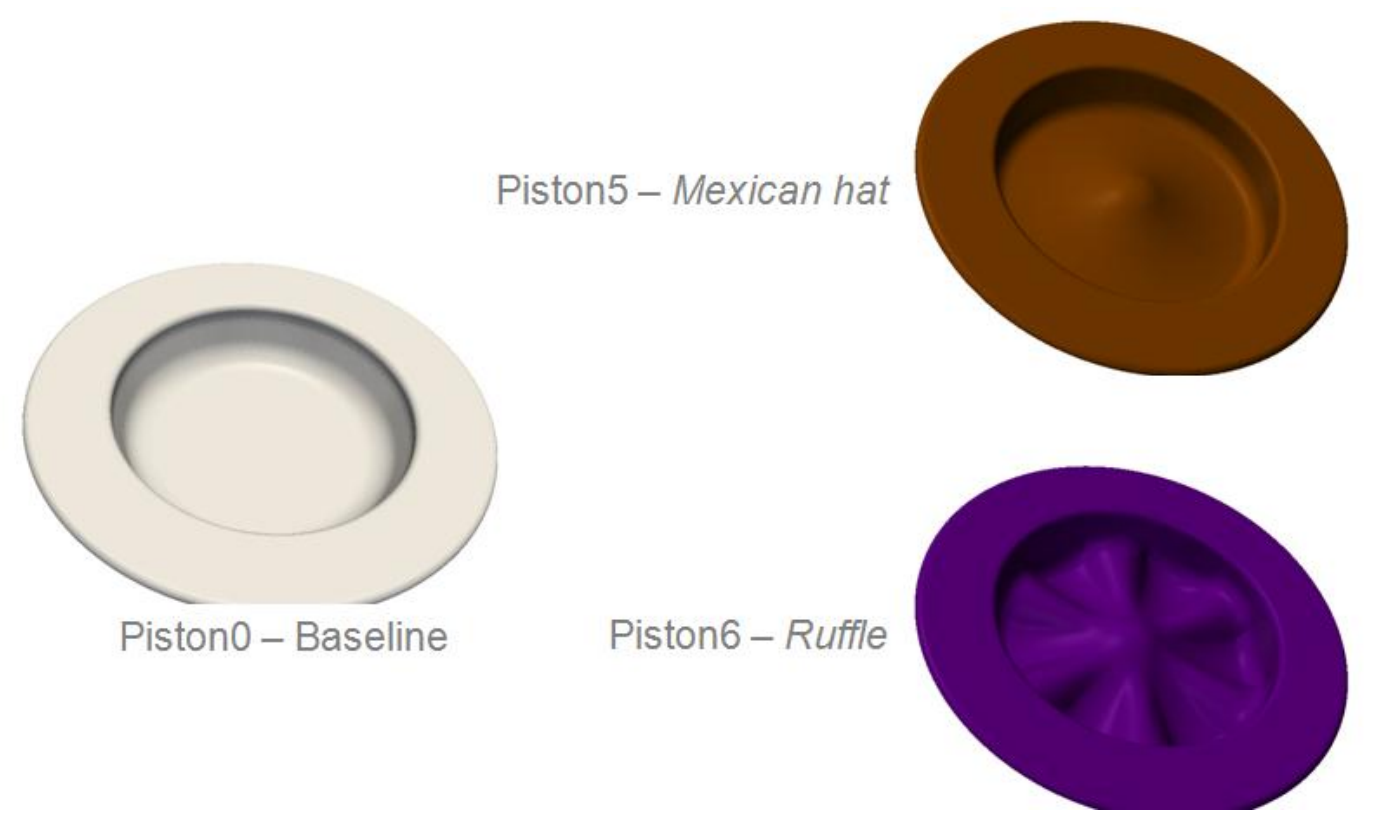

Figura 96 - Novas propostas de câmaras de combustão.

No comparativo ilustrado na Figura 97 o pistão 5 (Chapéu Mexicano) mostrou maiores níveis de energia cinética turbulenta no momento do disparo da centelha, e conforme esperado, houve o redirecionamento das microestruturas turbulentas para próximo da vela de ignição (Figura 98). 


\section{Fluxo: Cabeçote FEV}

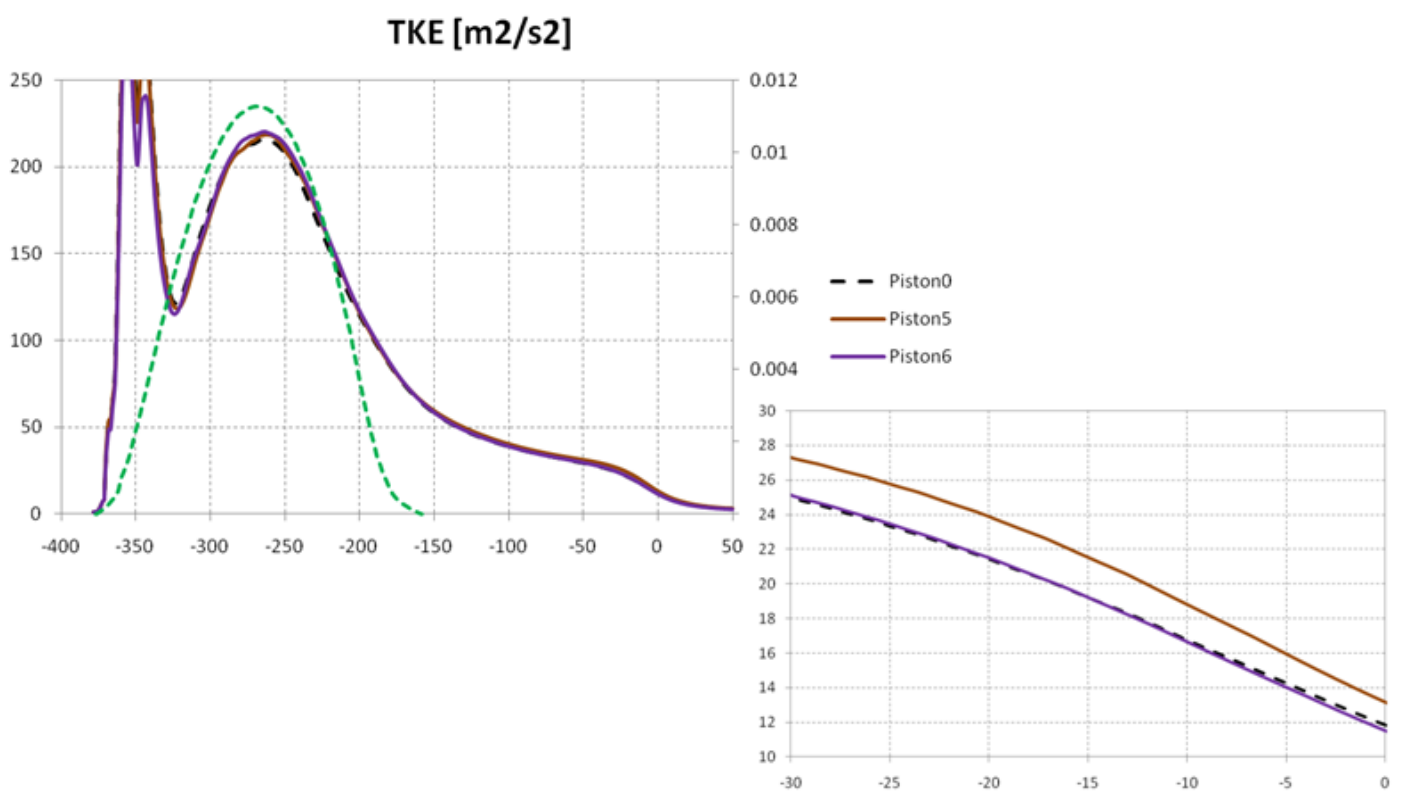

Figura 97 - Energia Cinética Turbulenta.

\section{Energia Cinética Turbulenta (Piston5)}

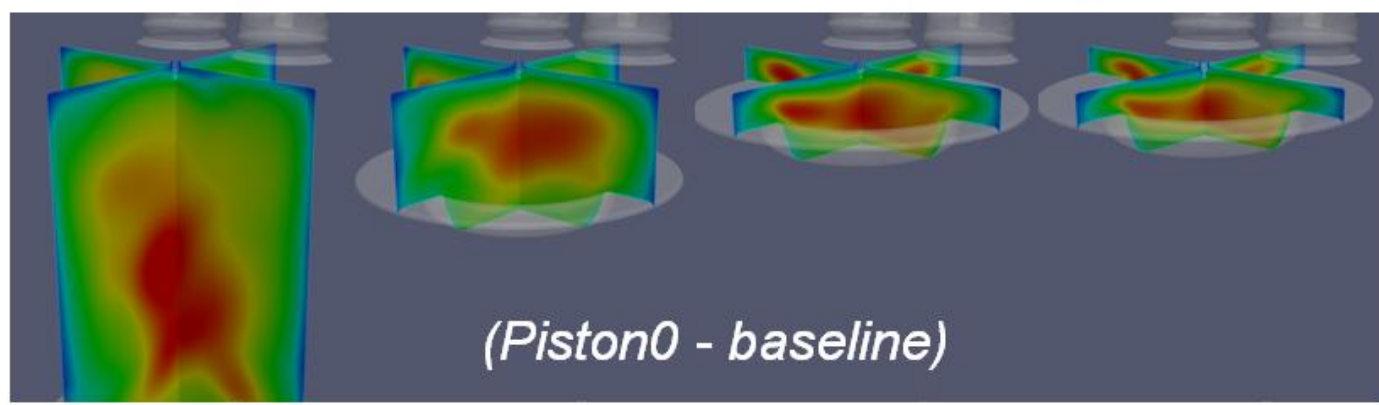

$150^{\circ} \mathrm{bTDC}$

$50^{\circ} \mathrm{bTDC}$

$20^{\circ} \mathrm{bTDC}$

$15^{\circ} \mathrm{bTDC}$

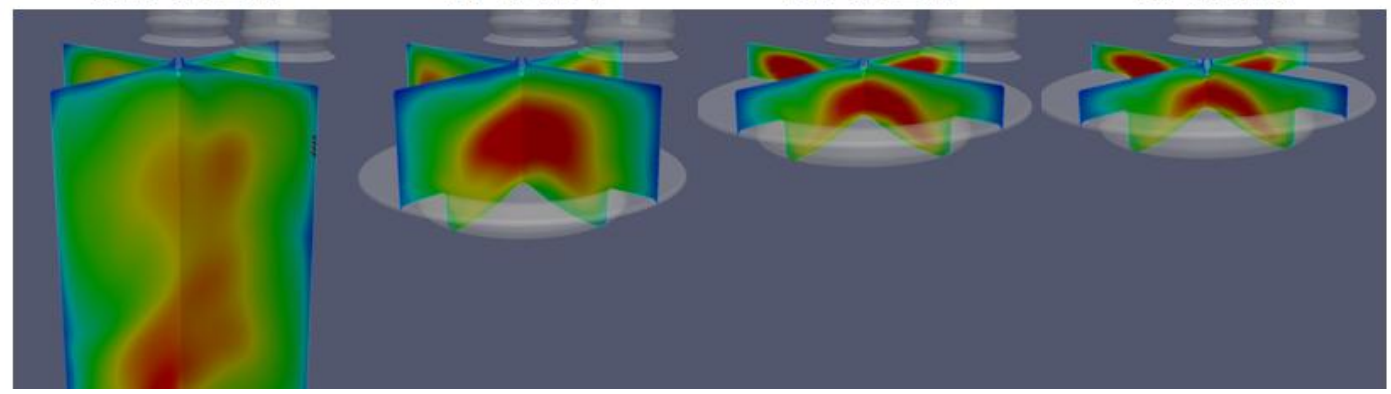

Figura 98 - Comparativo chapéu mexicano e baseline.

A Figura 99 mostra um comparativo dos projetos de pistões mais promissores, levando-se em consideração apenas escoamentos não reativos. 


\section{Comparativo: projetos mais promissores}

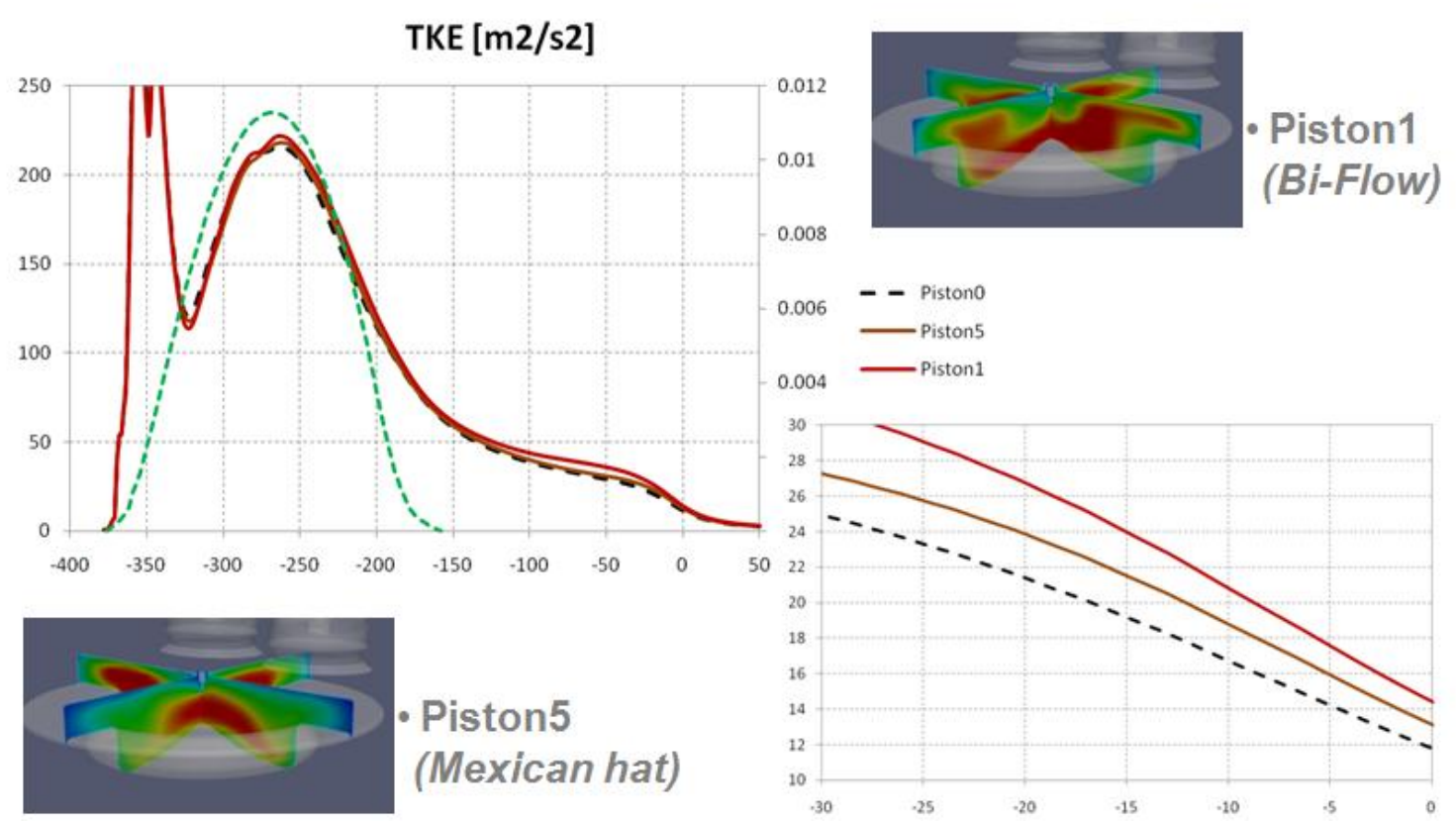

Figura 99 - Projetos mais promissores

Uma observação interessante diz respeito ao fato de que apesar da energia cinética turbulenta ser globalmente maior para a câmara do pistão 1 (Biflow), para o pistão 5 (Chapéu Mexicano) ela é mais concentrada na região central superior, ou seja, mais adequada à fase inicial da propagação da frente de chama. De fato, esse efeito será mostrado mais adiante no comparativo envolvendo combustão, e corroborado experimentalmente.

\subsubsection{Simulação da Combustão}

Para uma primeira análise do grau de predição do modelos de combustão foi feita uma comparação com dados experimentais, os quais foram processados com o auxílio do "GTPower", como o cálculo da taxa de queima, por exemplo. A massa de ar que entra no cilindro (Figura 100) foi simulado com um erro de cerca de $1 \%$ e a pressão de pico no interior do cilindro com cerca de 3\% (Figura 101). 
É importante ter em mente que há perdas térmicas que o modelo de combustão não é capaz de predizer com exatidão, e como a curva de pressão no cilindro é o ponto de partida para os cálculos das taxas de liberação de calor instantânea e acumula. Conhecer o erro da predição da curva de pressão apenas por compressão (motoring) auxilia na detecção do erro do modelo de combustão.

\section{Massa de ar no cilindro ("motoring")}

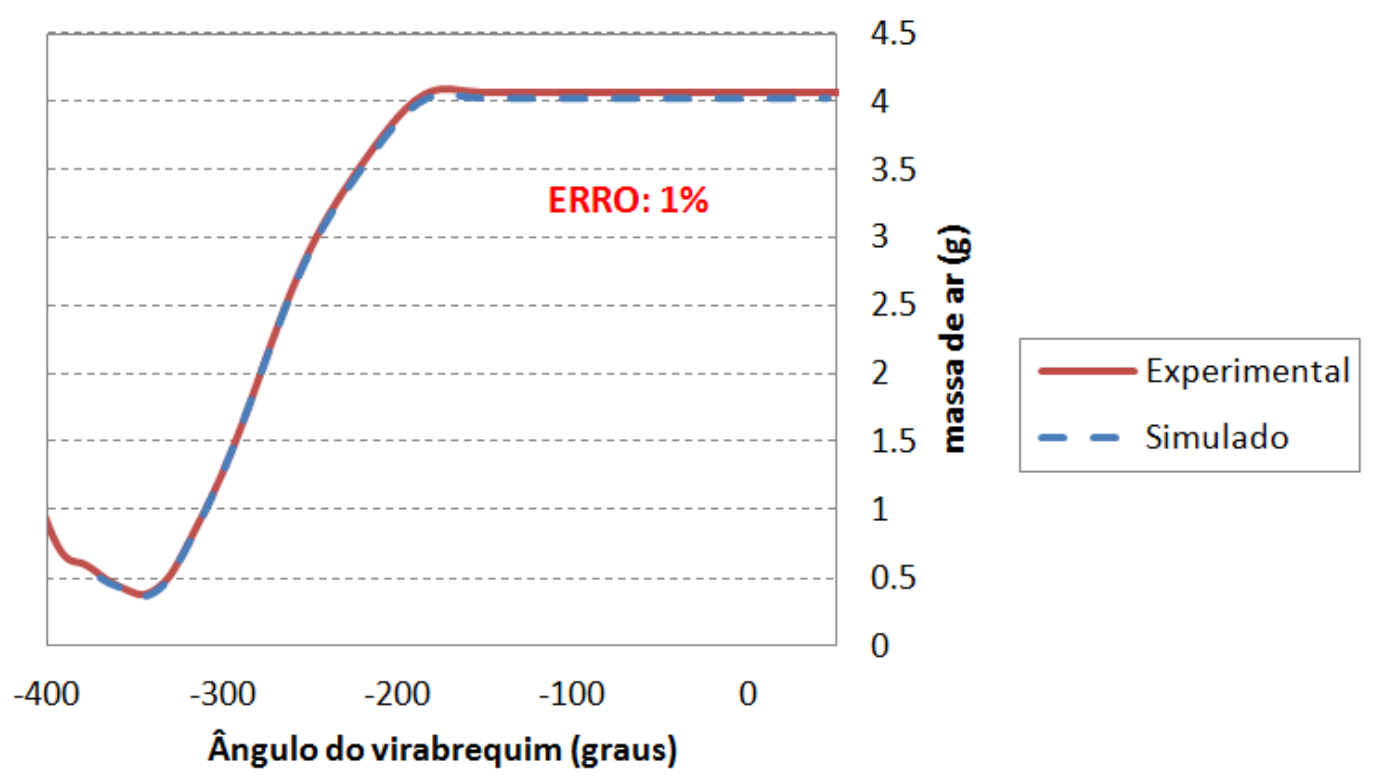

Figura 100 - Massa de ar no cilindro. 


\section{Pressão no cilindro}

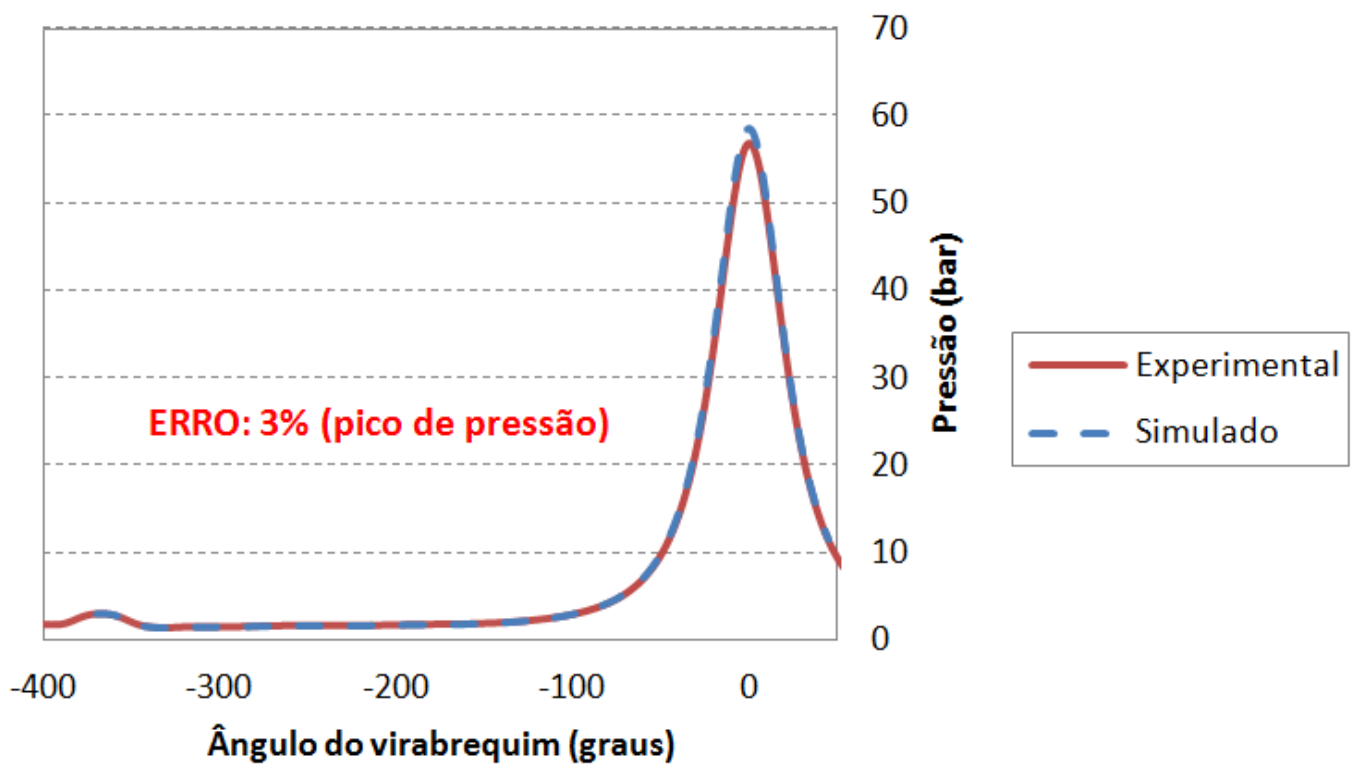

Figura 101 - Pressão no cilindro.

A Figura 102 apresenta uma comparação entre os dados experimentais (motor FEV) e os simulados, sendo estes: o baseline (pistão 0 - com base plana), "Biflow" (pistão 1 - com dois ressaltos laterais) e o "Mexhat" (pistão 5 - tipo chapéu mexicano). Uma primeira observação se liga ao fato de a taxa instantânea de liberação de calor ser mais acentuada na simulação do “baseline" em relação ao obtido experimentalmente, pois a condição imposta de homogeneidade total pode ser uma explicação para tal diferença. Este fato será mostrado mais adiante na análise do processo de formação de mistura ar / combustível.

Envolvendo combustão, a câmara com o pistão 1 (“biflow”) se mostrou menos eficaz que o próprio "baseline", entretanto a câmara com o pistão 5 ("mexhat") foi a que conduziu a maior taxa instantânea de queima (Figura 102).

Observando a curva de liberação de calor "acumulado", fica bem marcante que para o pistão 5, tem-se o maior percentual de queima no menor ângulo do virabrequim (Figura 103). 


\section{Taxa instantânea de liberação de calor}

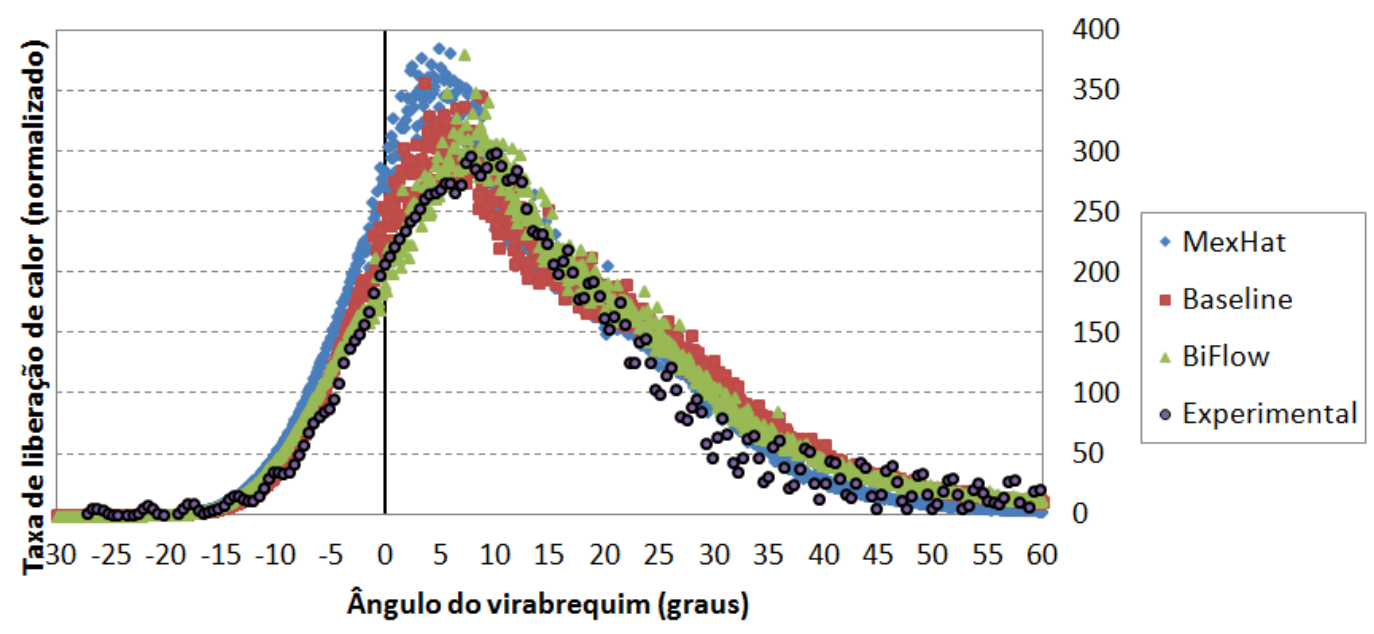

Figura 102 - Comparativo entre dados simulados e experimentais.

\section{Liberação de calor (acumulado)}

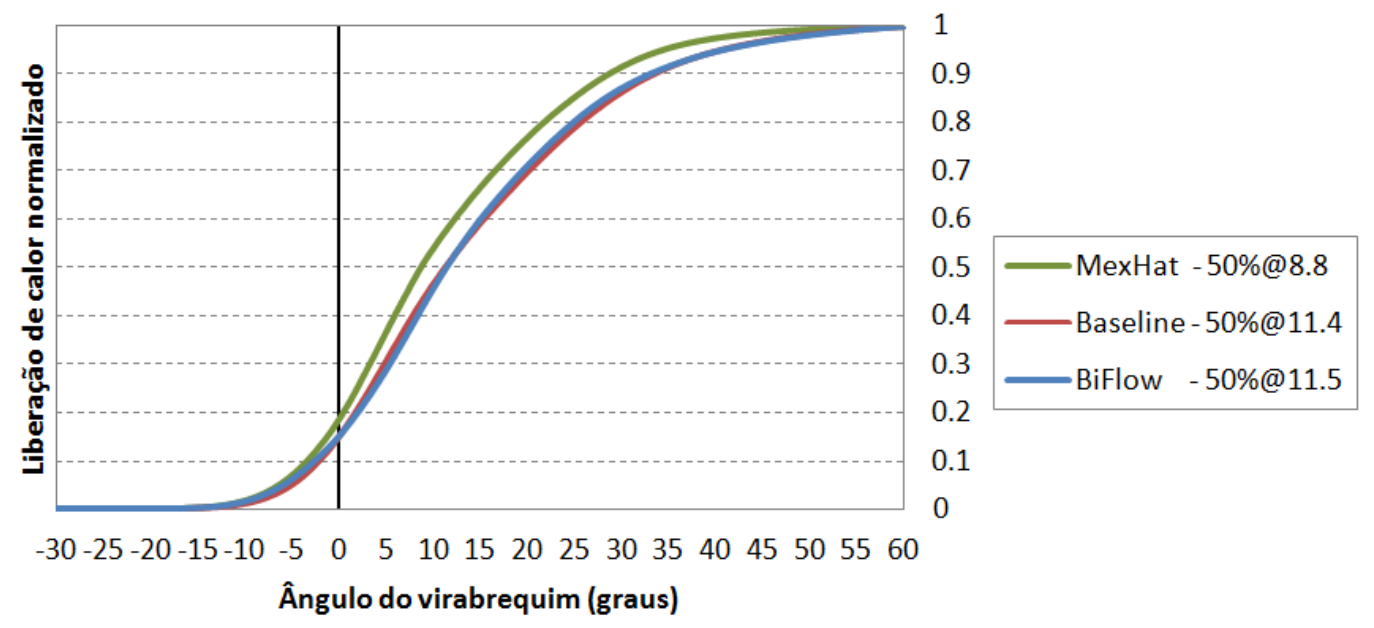

Figura 103 - Comparativo entre dados simulados - calor acumulado.

Conforme citado anteriormente, usualmente o MBT ocorre quando $50 \%$ de massa queimada se situa em torno de $7^{\circ}$ DPMS. Observando a figura 103 e comparando com a 102 , percebe-se que o motor só se aproxima do MBT para a configuração do pistão 5 (Mexhat), ou seja, nem mesmo o motor experimental se encontra nessa condição experimentalmente. De fato, o motor operava em plena carga limitado pelo "LDI" (limite de detonação inferior), sendo esta condição um dos motivos para a busca de uma câmara de combustão menos suscetível ao fenômeno de detonação. 
Para uma melhor compreensão do resultado mostrado na análise gráfica, serão descritas algumas representações dos processos de propagaçãos das frentes de chamas para cada caso em questão. Assim, é possível observar como cada geometria influencia cada etapa do processo.

A sequência representada pelas figuras Figura 104, Figura 105, e Figura 106 ilustra a propagação da frente de chama e a taxa instantânea de queima a $8^{\circ}$ APMS para as câmaras "Baseline", "Biflow" e Chapéu Mexicano (Mexhat)", respectivamente. Nessa fase, nota-se uma queima mais lenta para a configuração "Baseline", o que não se mantém em relação à configuração "Biflow", conforme ilustrados pelas figuras Figura 110 e Figura 111. Em toda a sequência, a configuração "Mexhat" mostra uma propagação mais rápida da frente de chama.

A relação entre velocidade de propagação da frente de chama e energia cinética turbulenta fica bem representada pelas figuras Figura 119, Figura 120, e Figura 121, o que auxilia a compreensão sobre as distorções que existem nas próprias frentes de chamas observadas na sequência. 


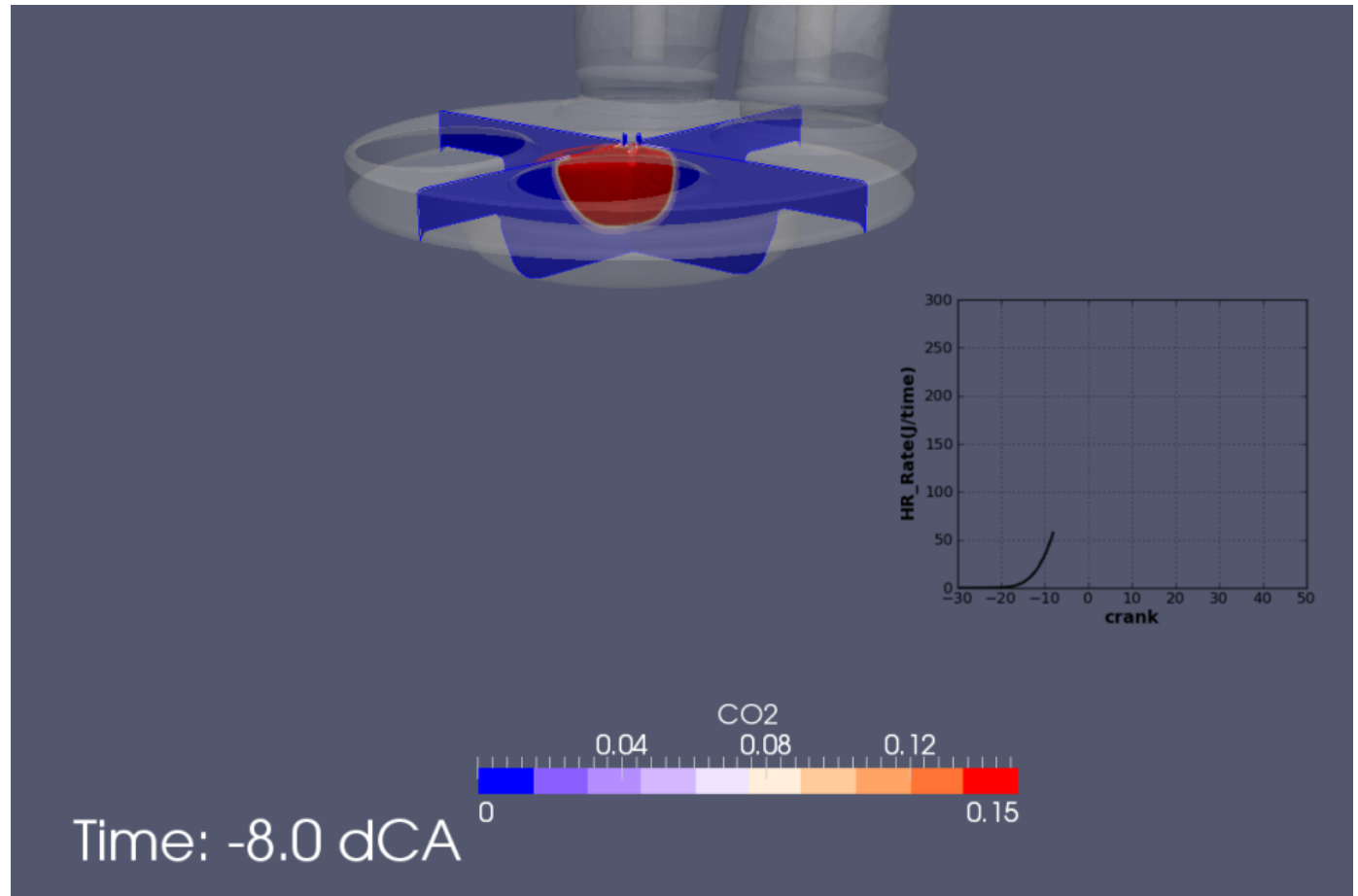

Figura 104 - Frente de chama e taxa de queima a $8^{\circ}$ APMS ("Baseline").

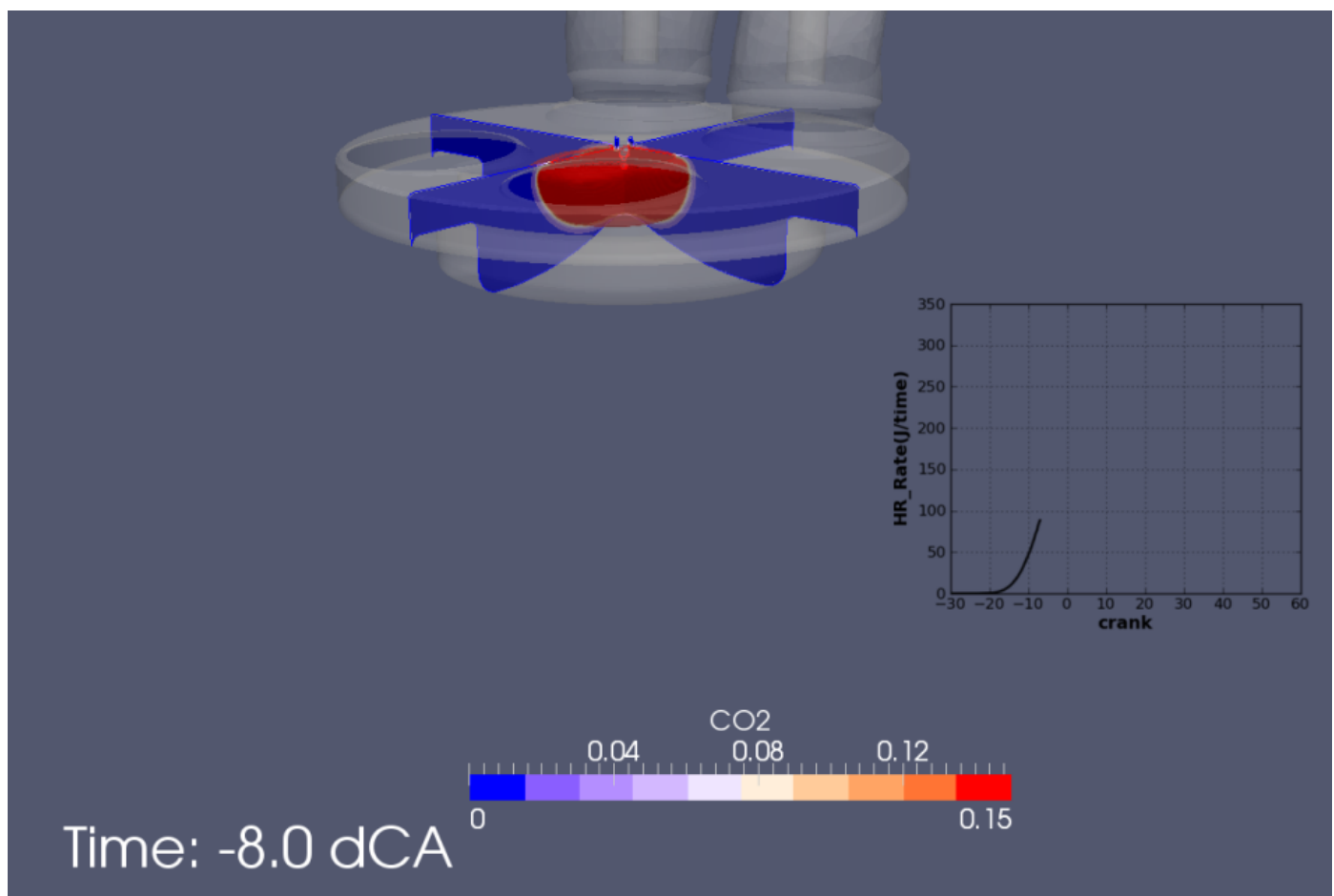

Figura 105 - Frente de chama e taxa de queima a $8^{\circ}$ APMS ("Biflow"). 


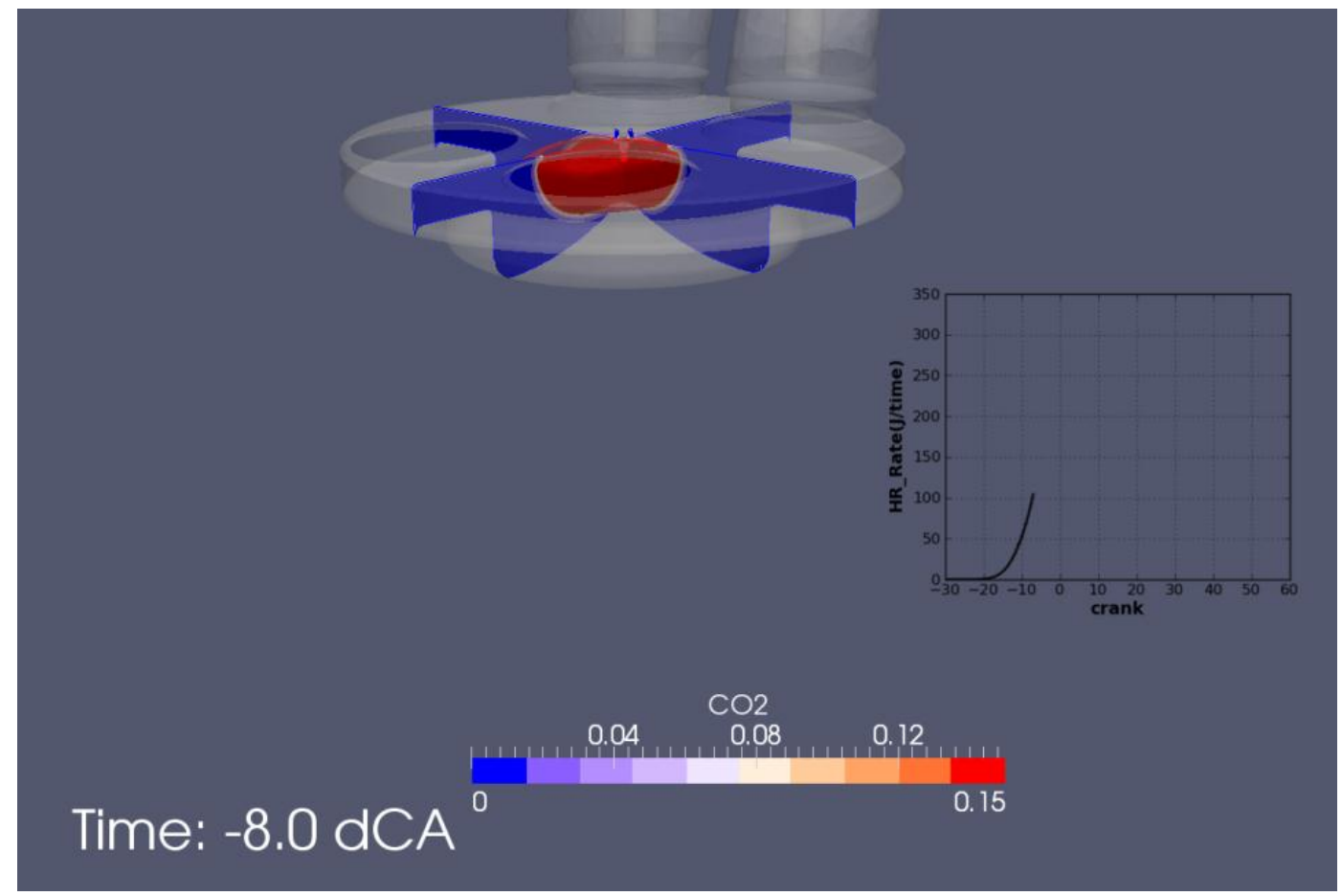

Figura 106 - Frente de chama e taxa de queima a $8^{\circ}$ APMS ("Mexhat').

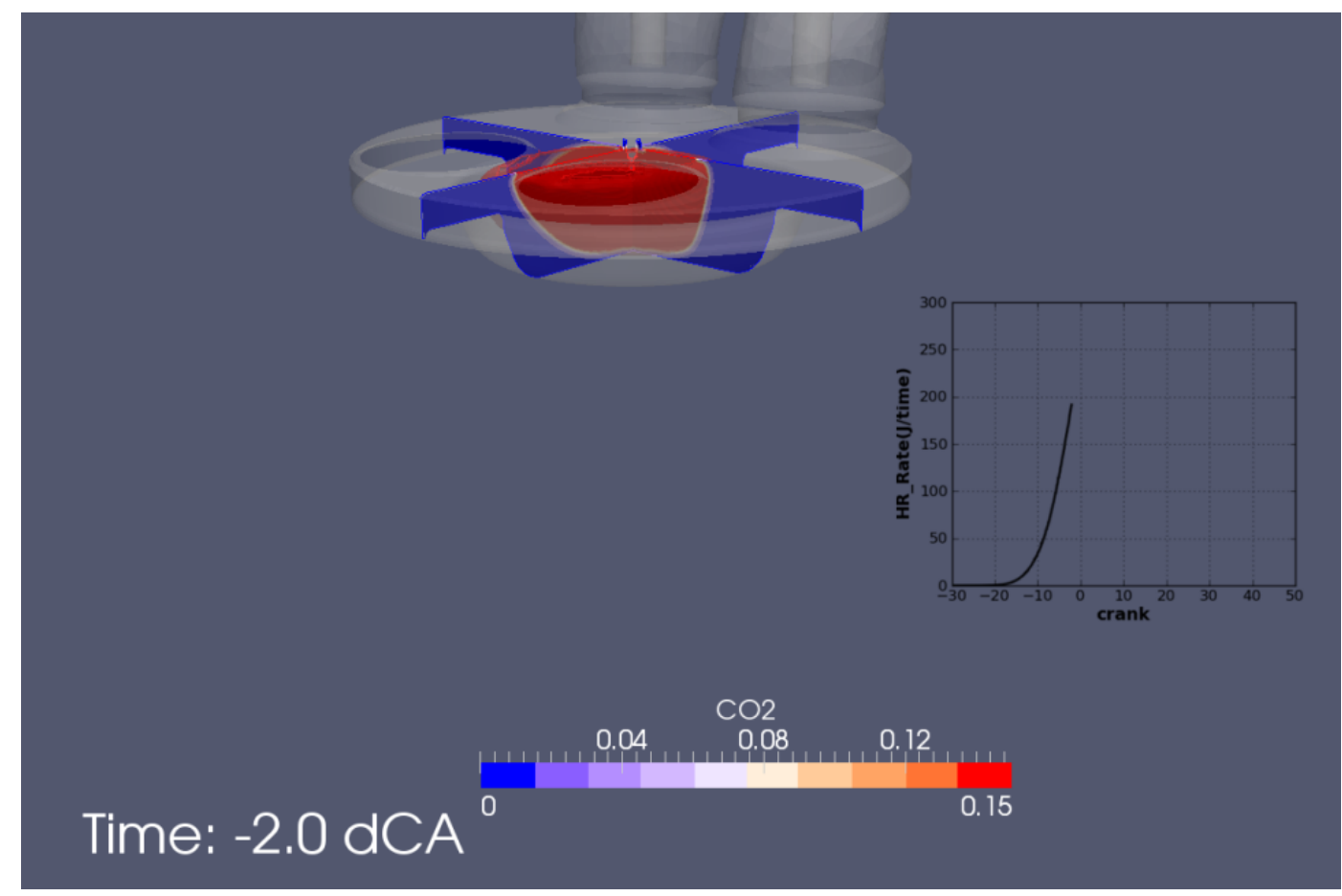

Figura 107 - Frente de chama e taxa de queima a $2^{\circ}$ APMS ("Baseline"). 


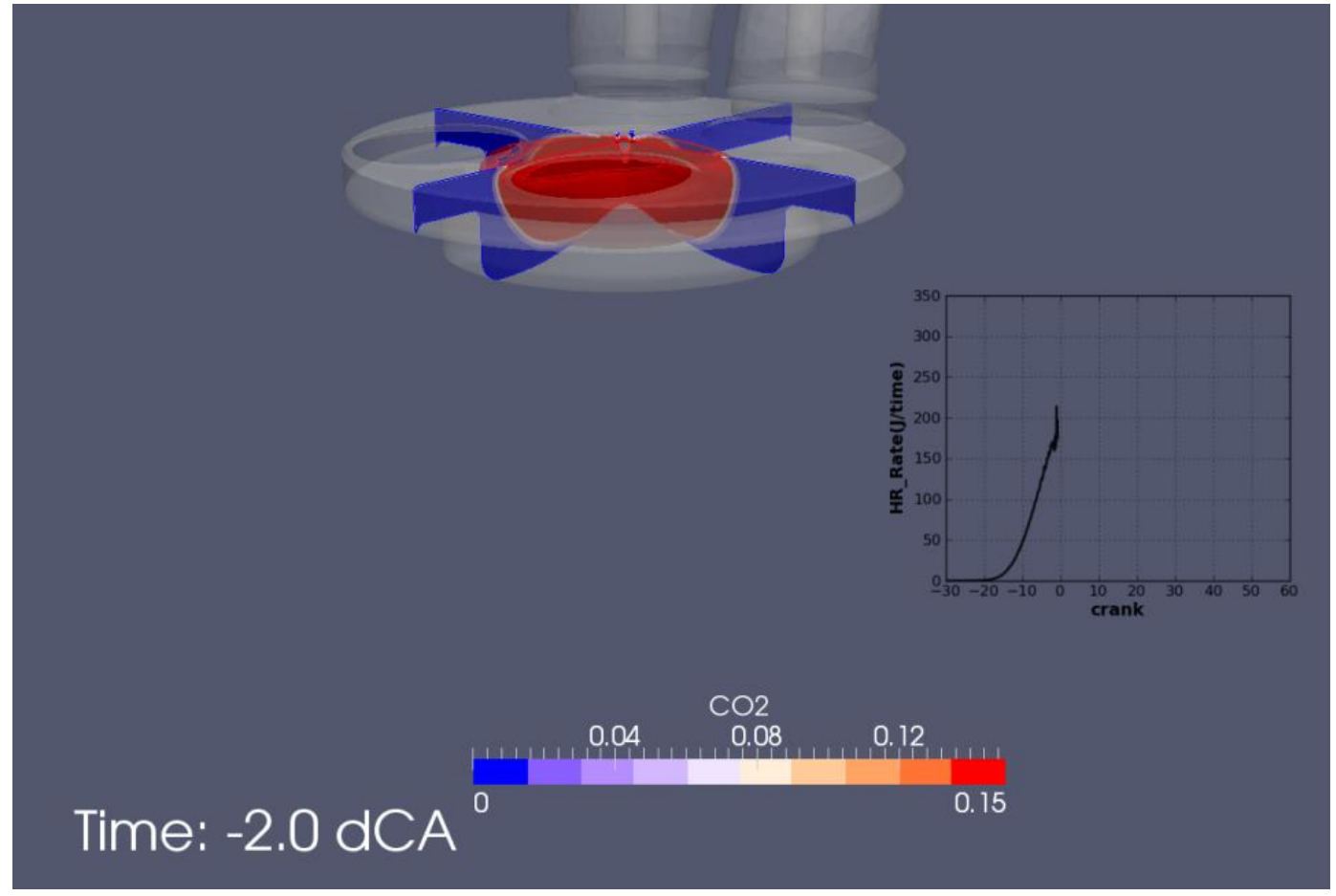

Figura 108 - Frente de chama e taxa de queima a $2^{\circ}$ APMS ("Biflow").

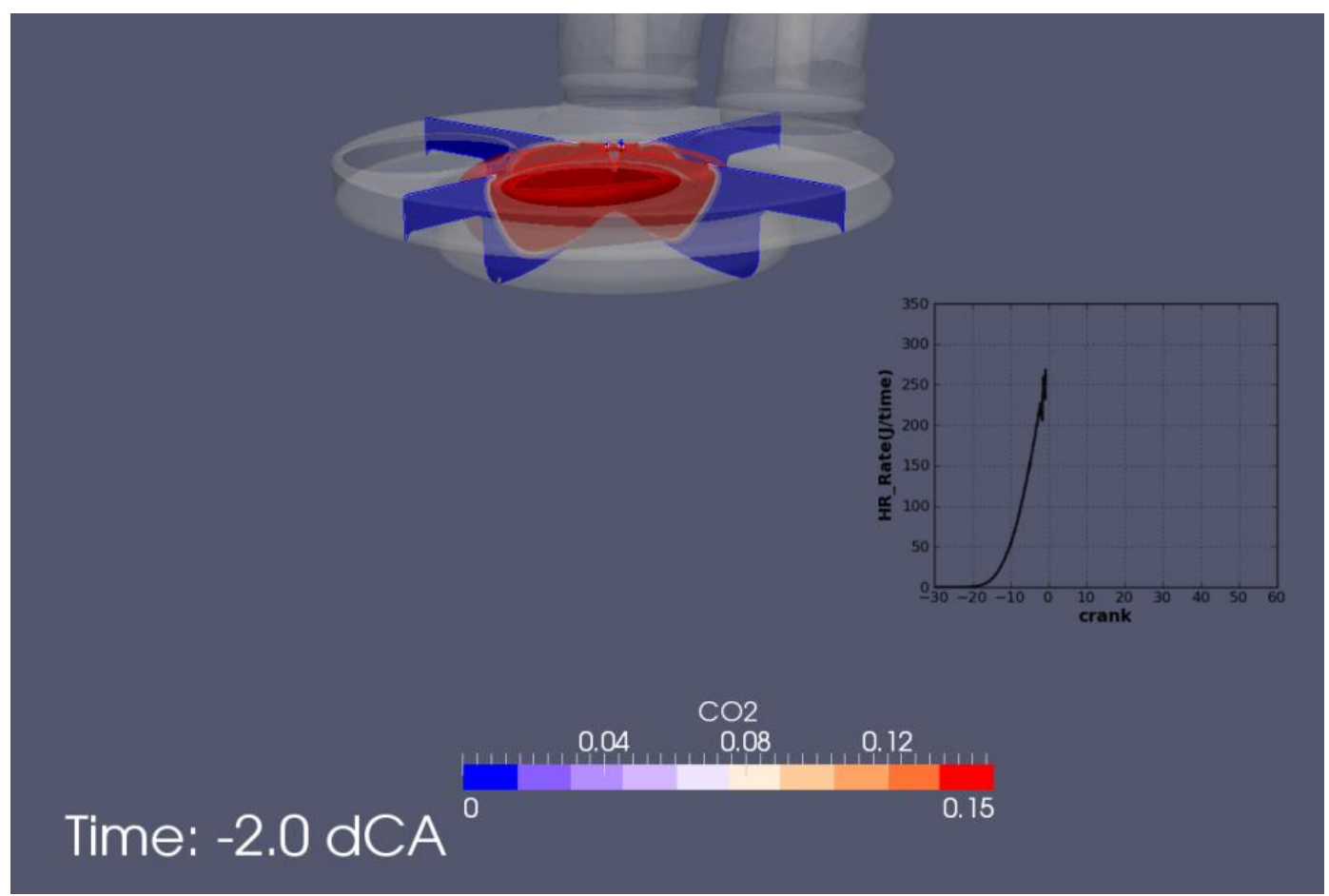

Figura 109 - Frente de chama e taxa de queima a $2^{\circ}$ APMS ("Mexhat"). 


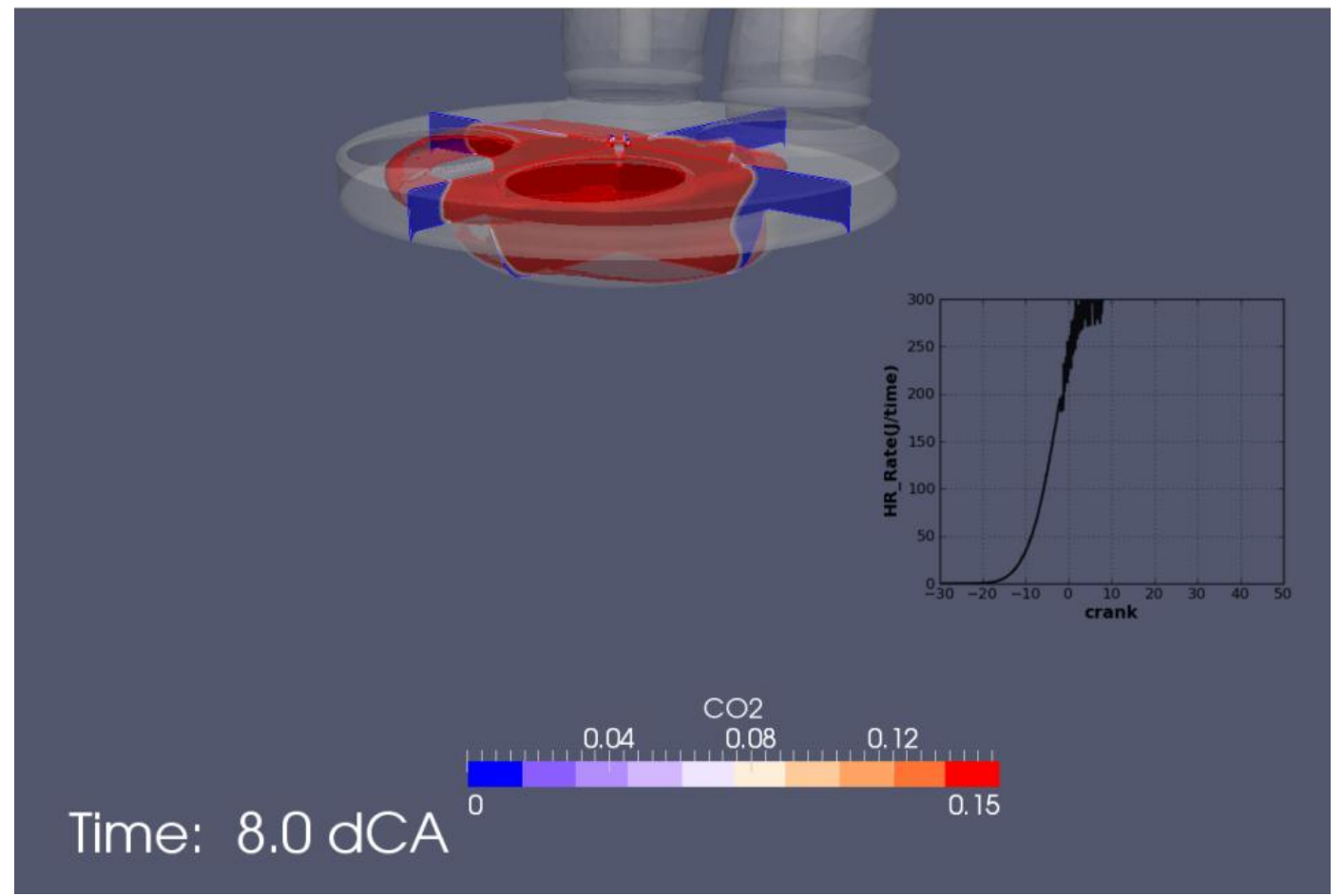

Figura 110 - Frente de chama e taxa de queima a $8^{\circ}$ DPMS ("Baseline").

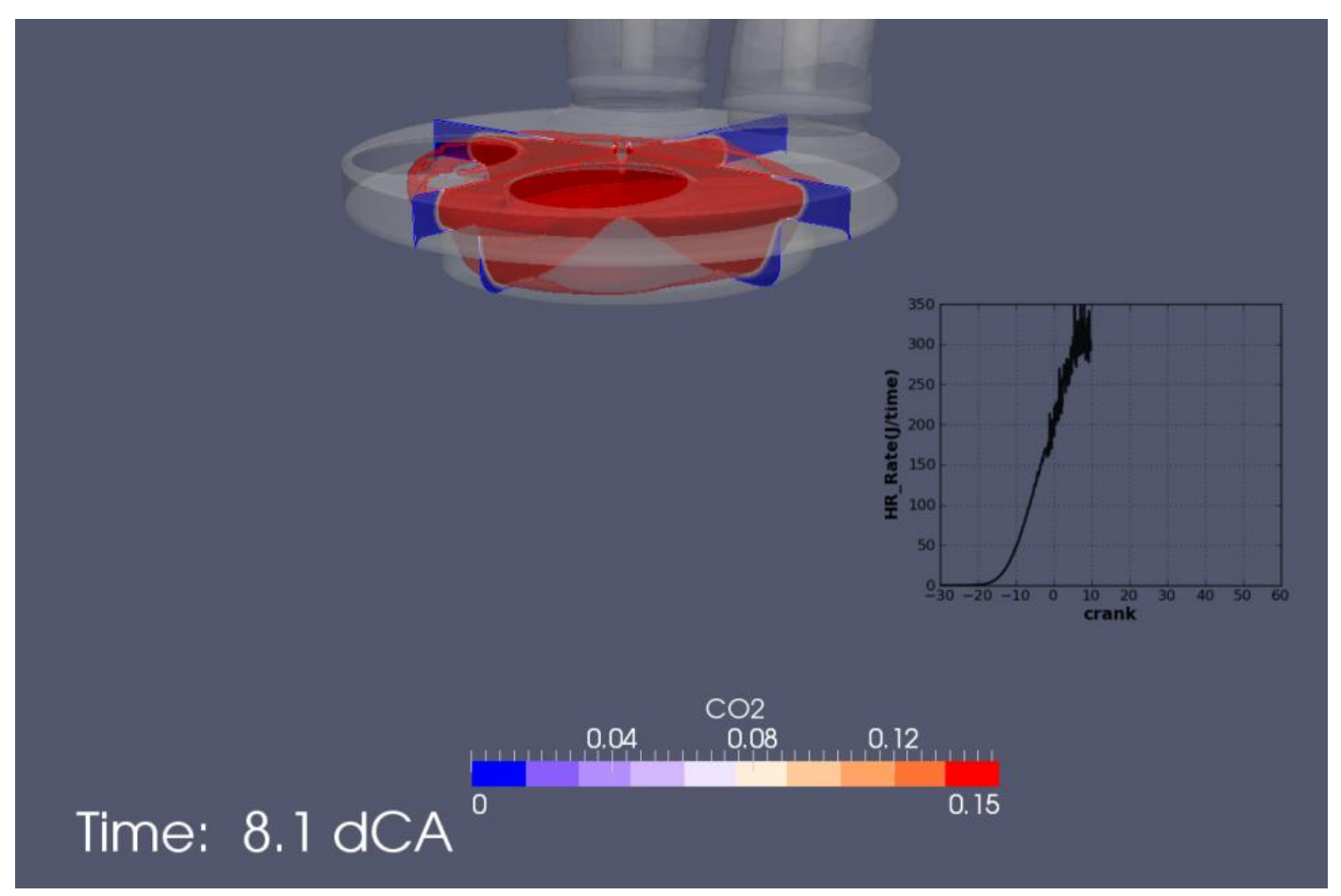

Figura 111 - Frente de chama e taxa de queima a $8^{\circ}$ DPMS ("Biflow"). 


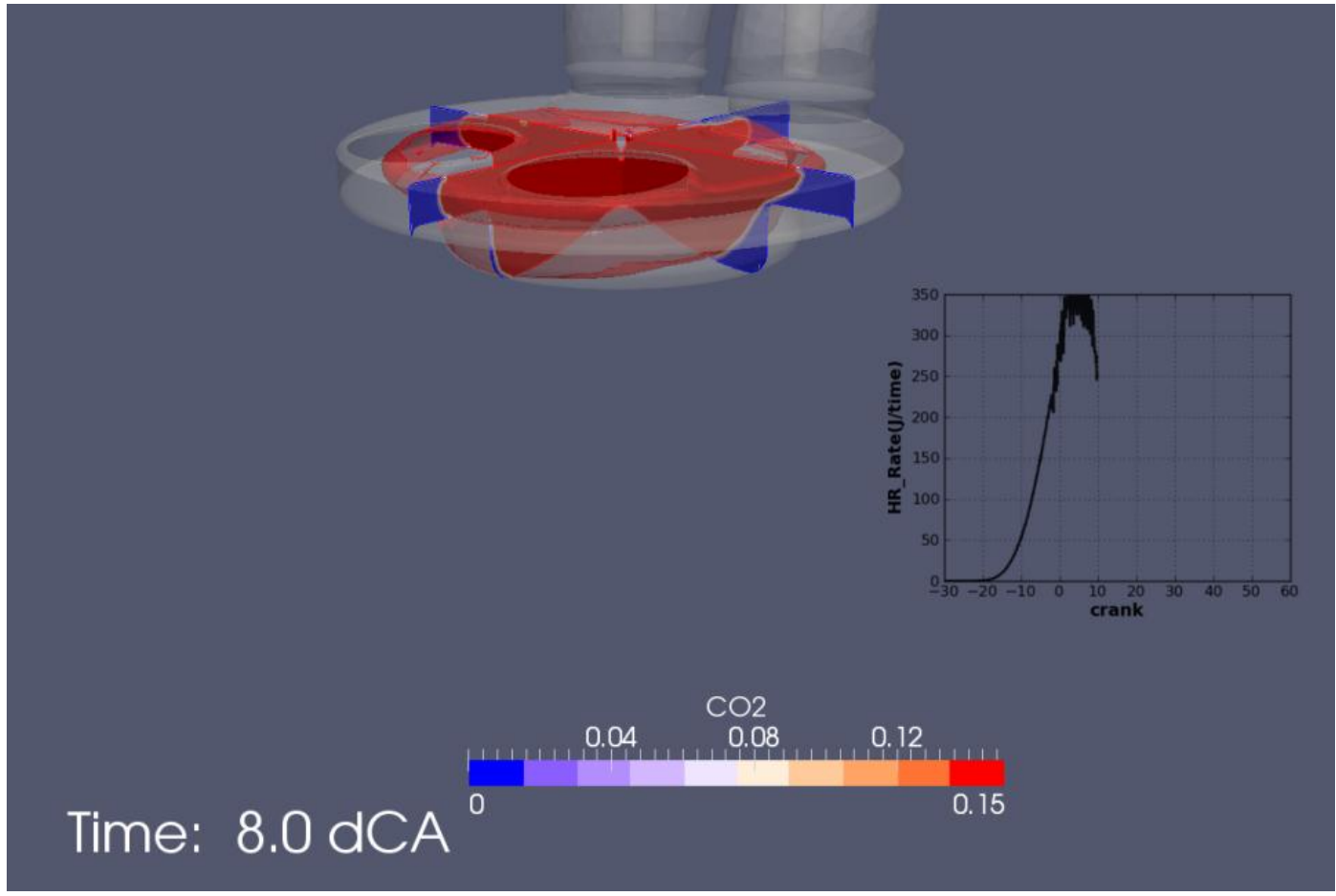

Figura 112 - Frente de chama e taxa de queima a $8^{\circ}$ DPMS ("Maxhat").

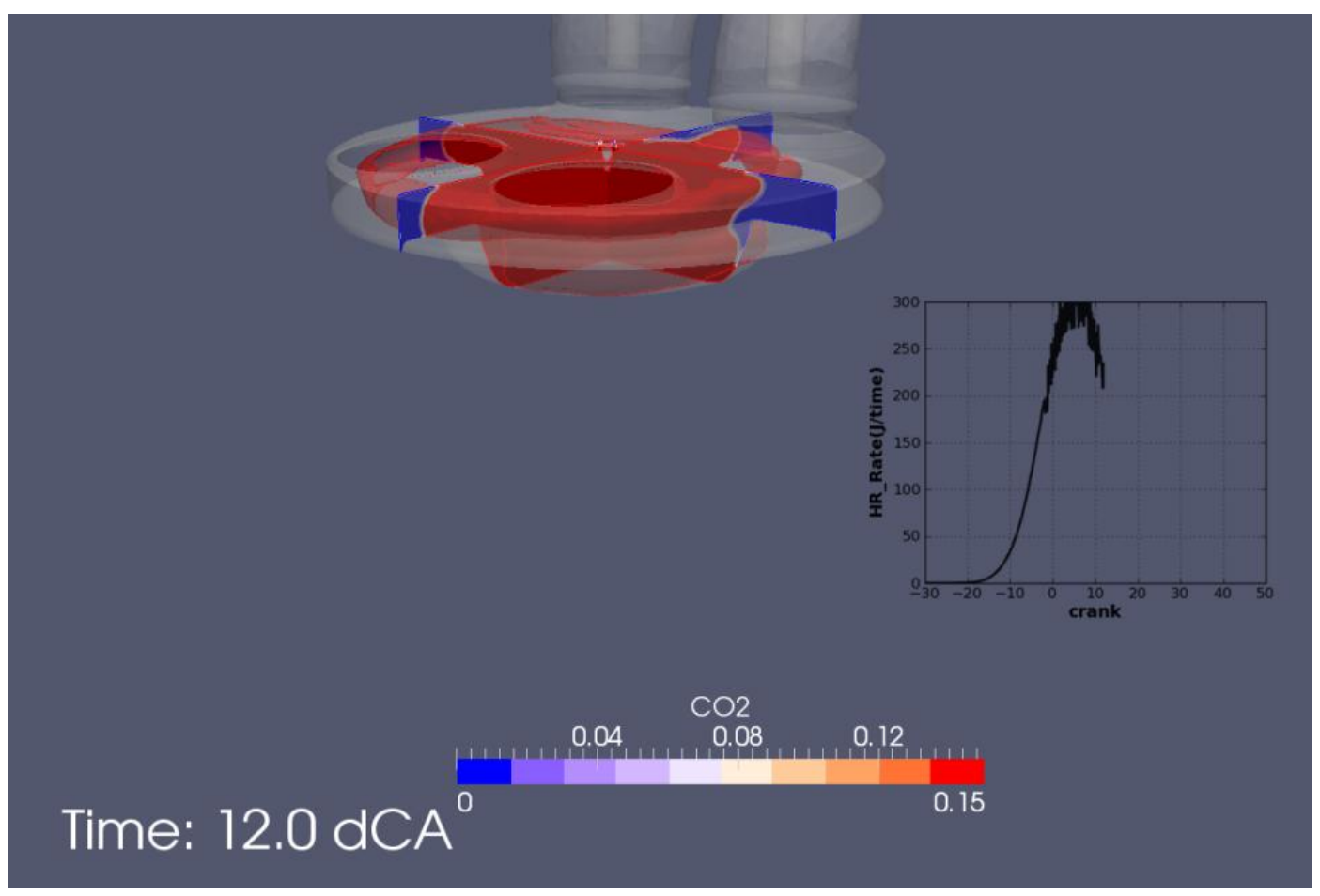

Figura 113 - Frente de chama e taxa de queima a $12^{\circ}$ DPMS (“Baseline”). 


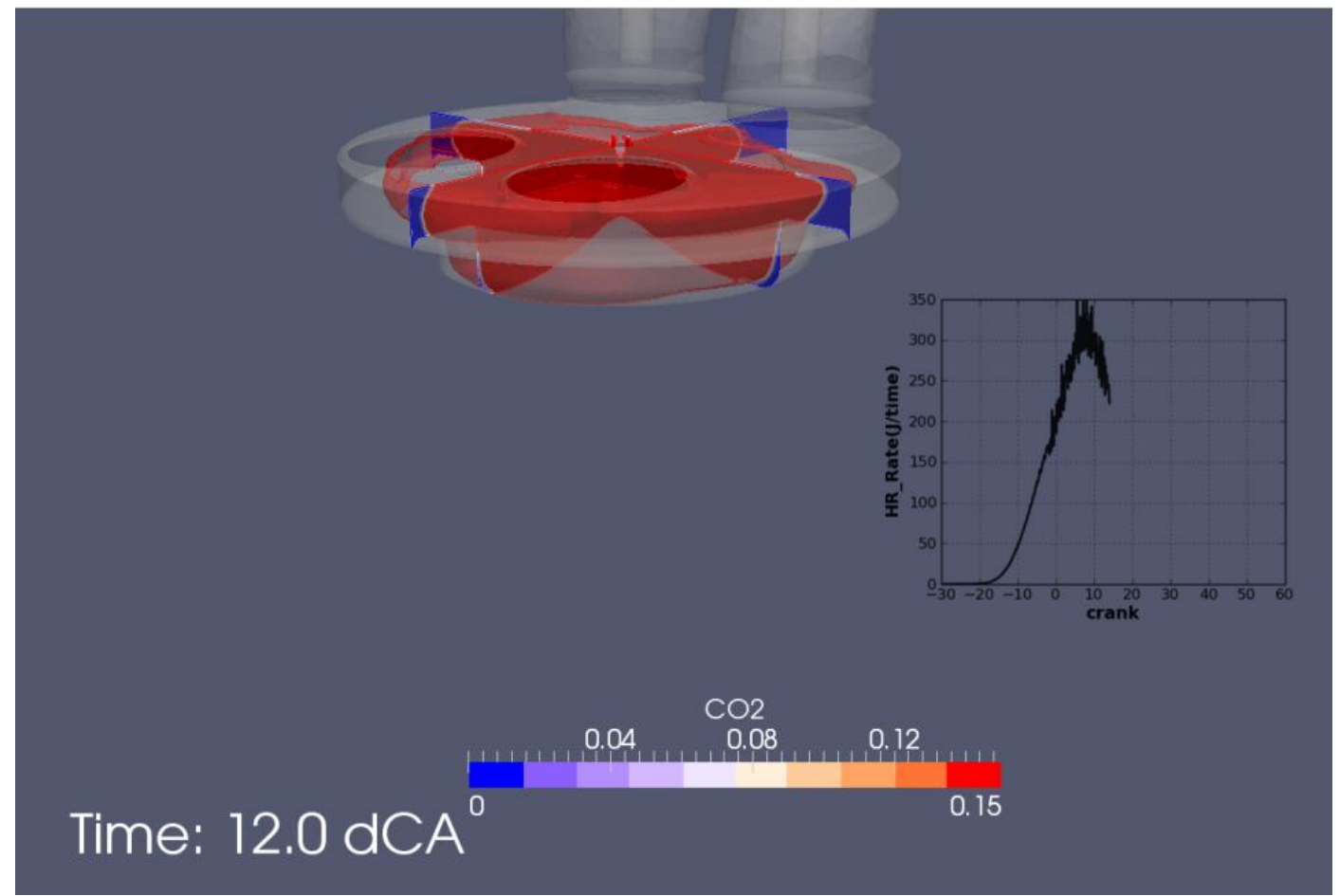

Figura 114 - Frente de chama e taxa de queima a $12^{\circ}$ DPMS (“Biflow”).

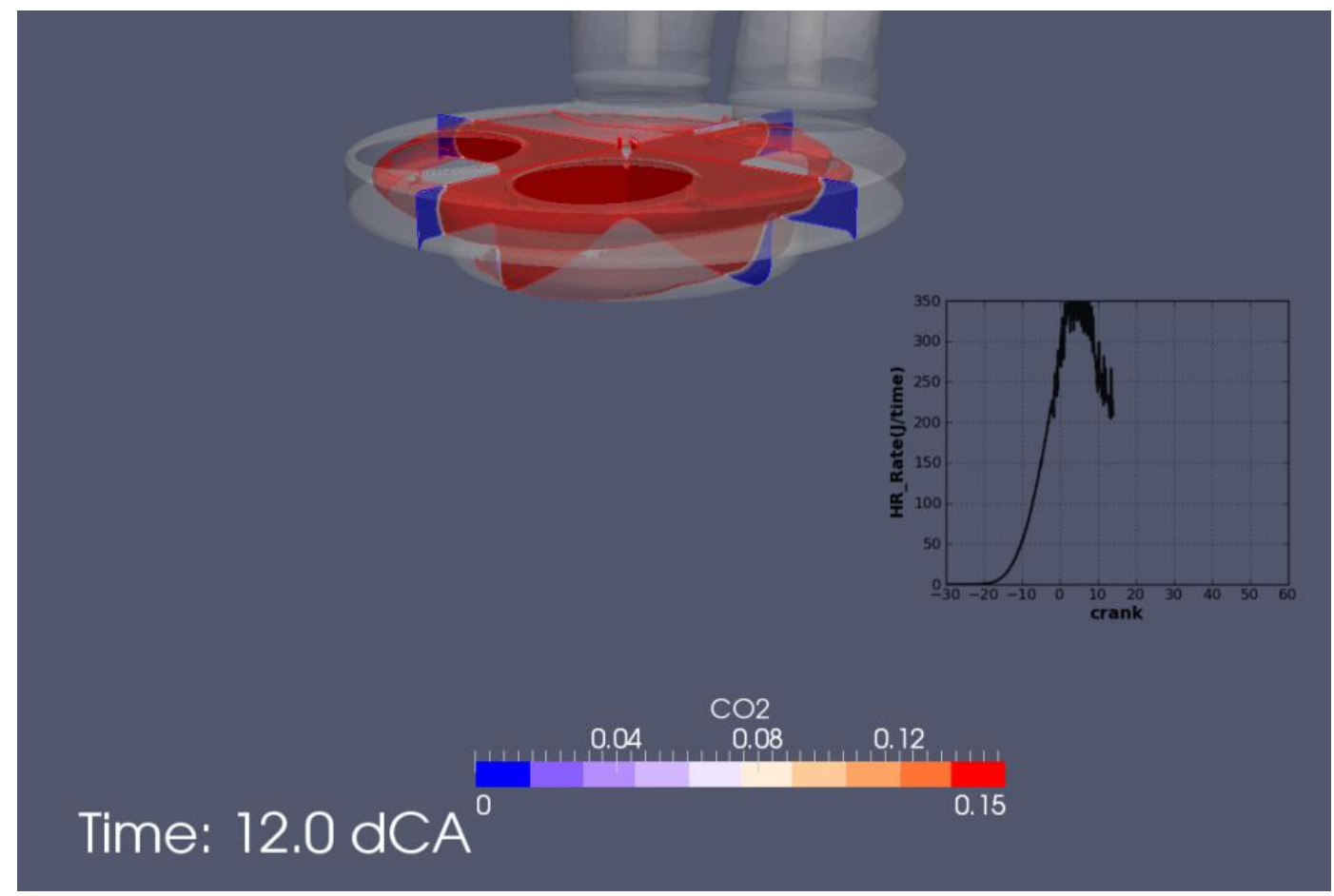

Figura 115 - Frente de chama e taxa de queima a $12^{\circ}$ DPMS ("Mexhat"). 


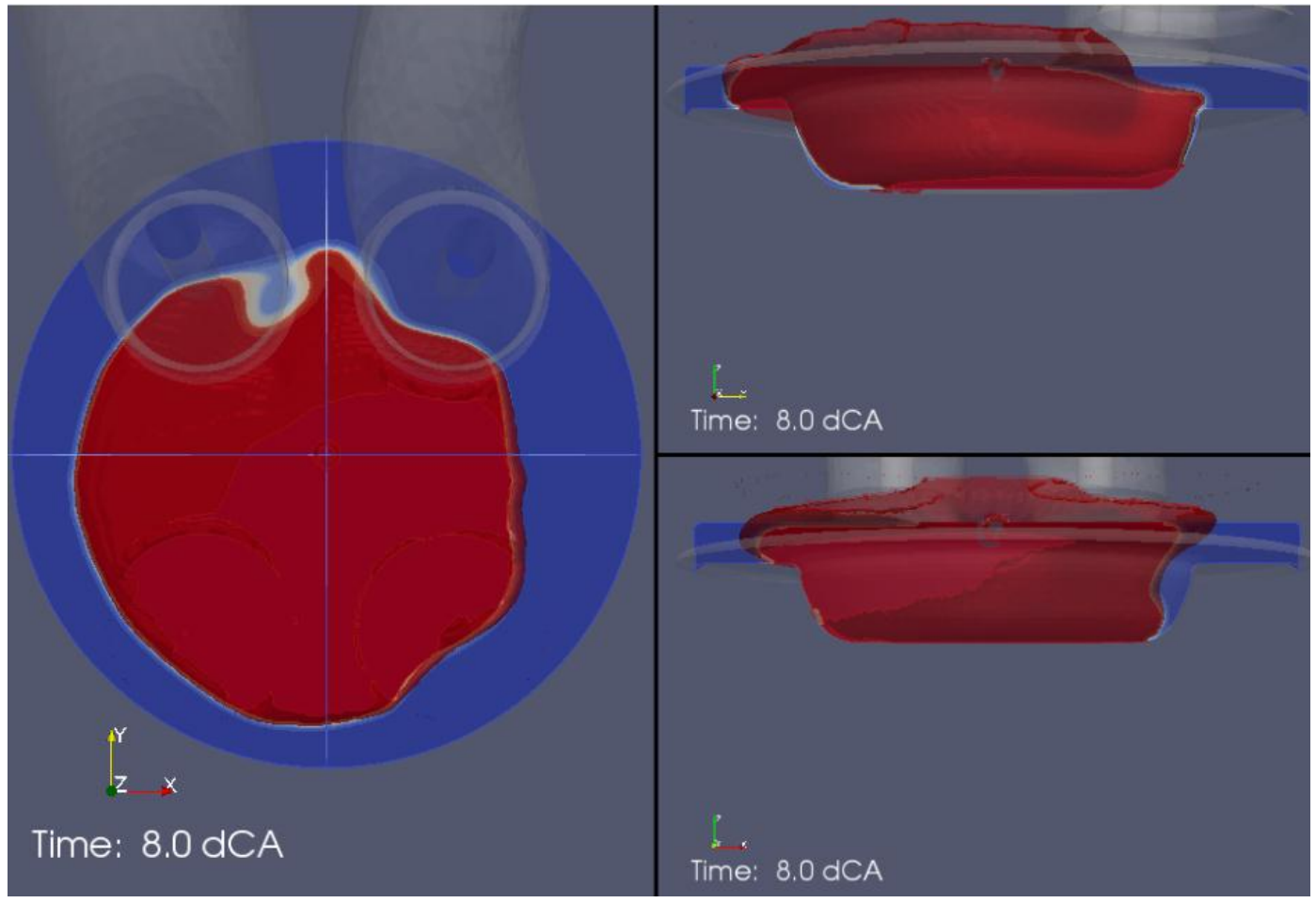

Figura 116 - Frente de chama a $8^{\circ}$ DPMS ("Baseline").

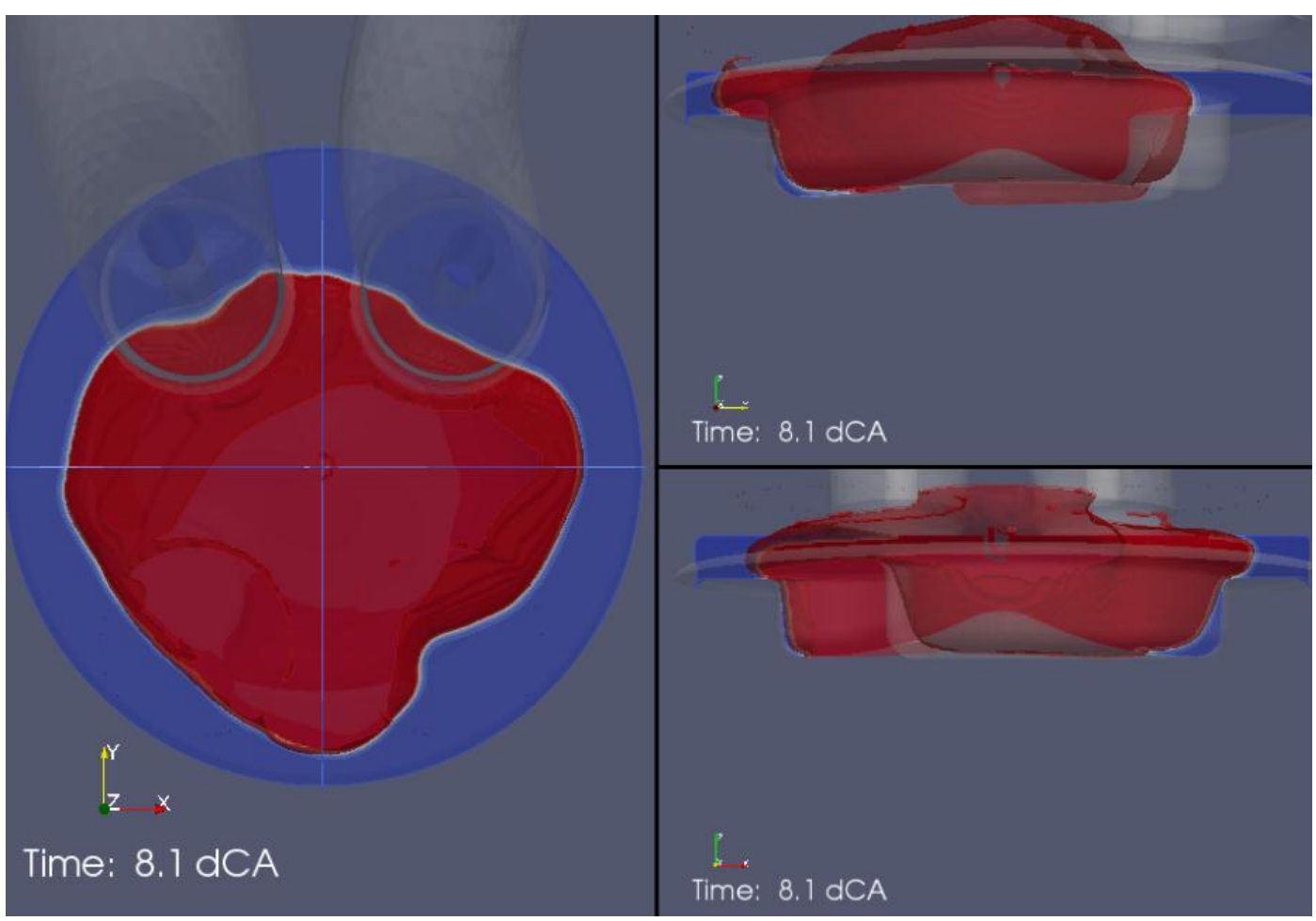

Figura 117 - Frente de chama a $8^{\circ}$ DPMS ("Biflow"). 


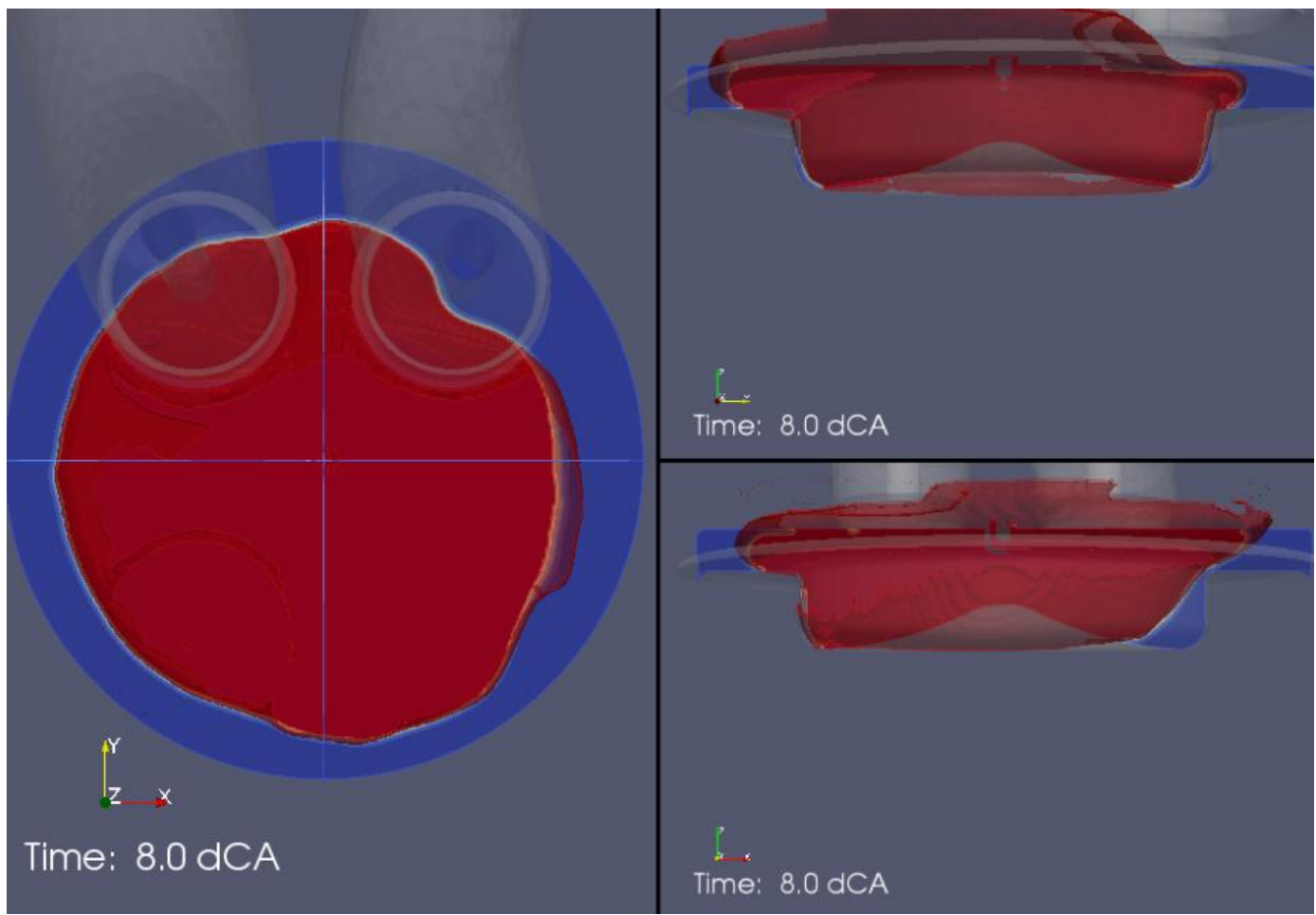

Figura 118 - Frente de chama a $8^{\circ}$ DPMS (“Mexhat”).

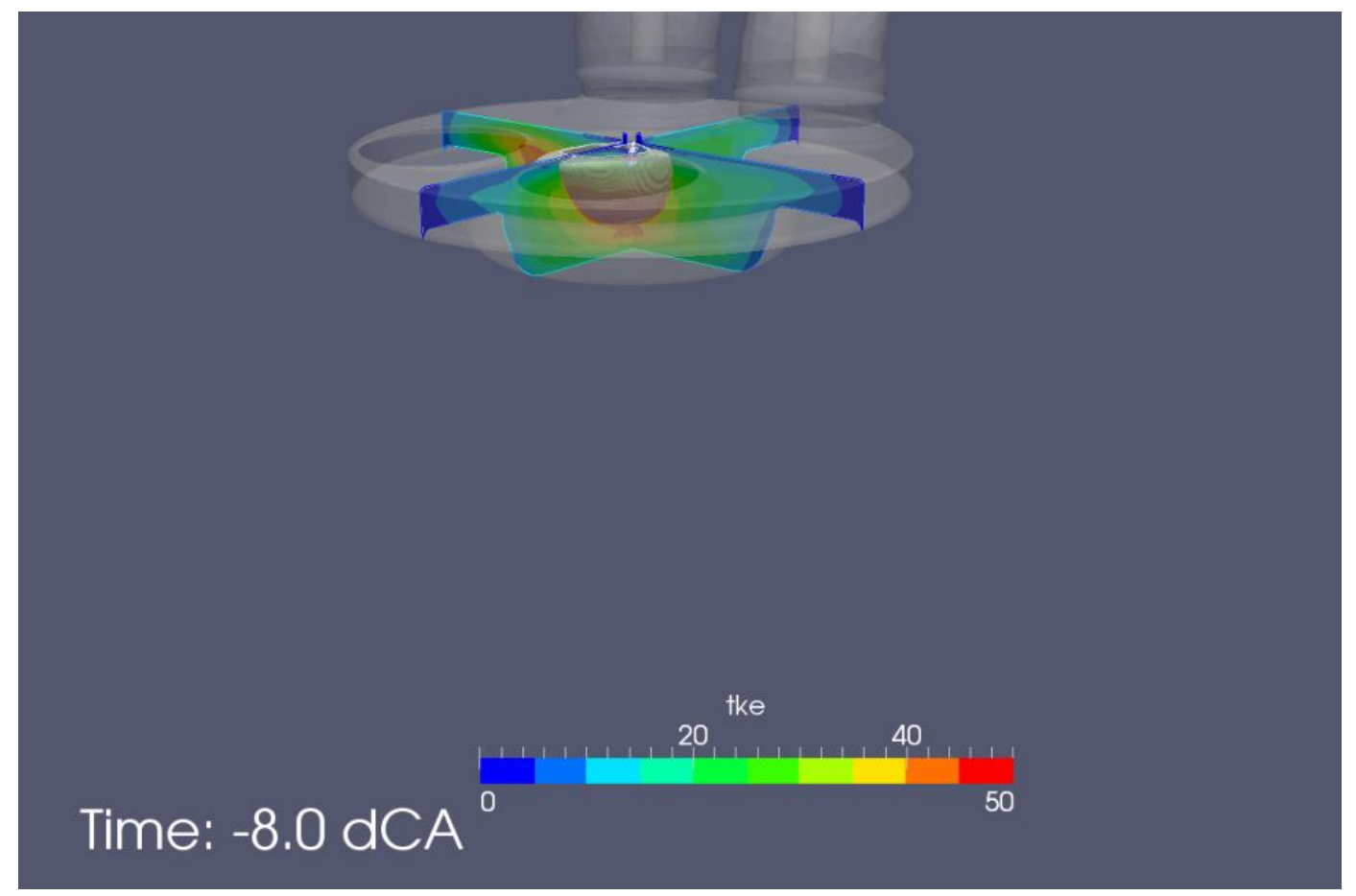

Figura 119 - Frente de chama e energia cinética turbulenta a $8^{\circ}$ APMS ("Baseline"). 


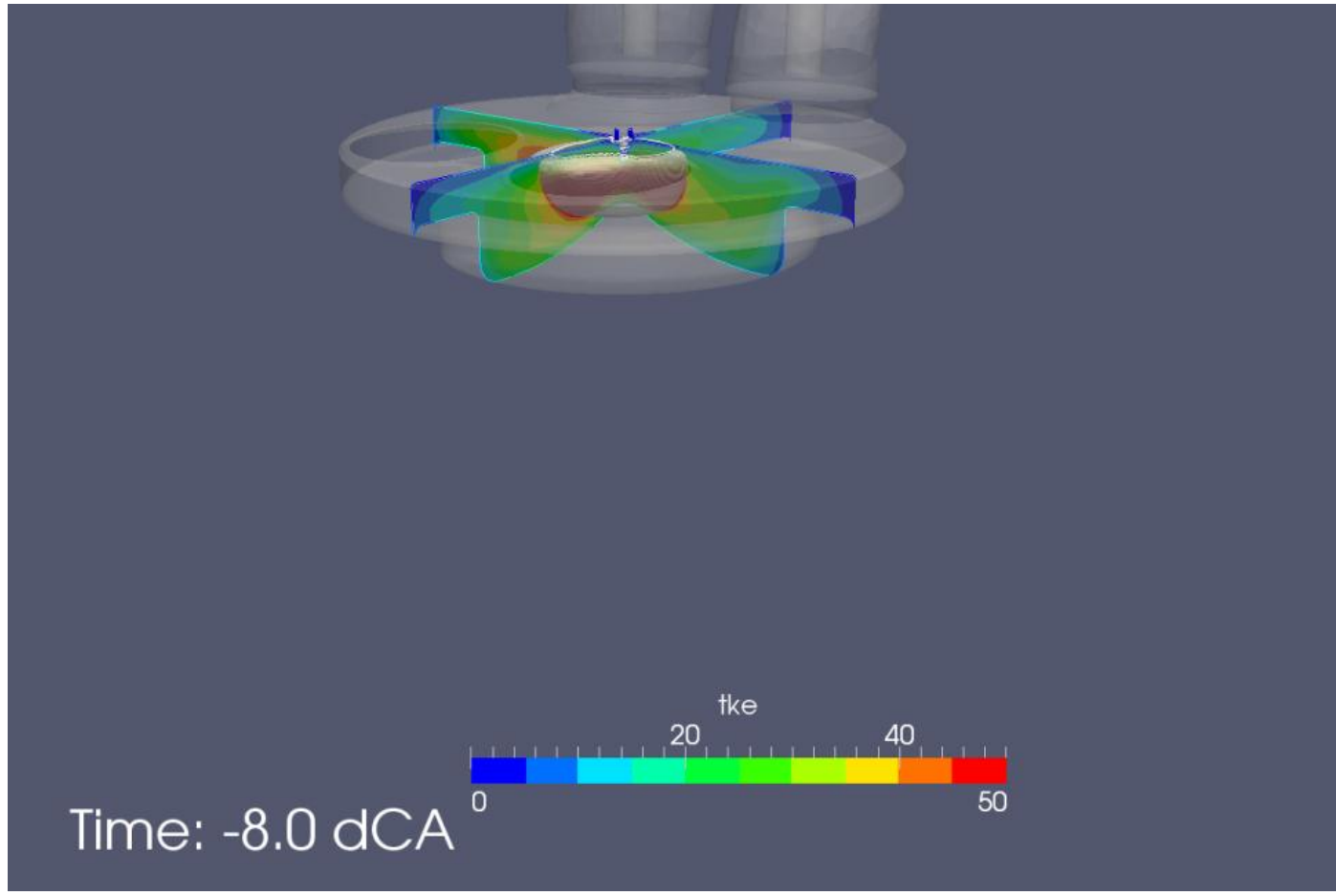

Figura 120 - Frente de chama e energia cinética turbulenta a $8^{\circ}$ APMS ("Biflow”).

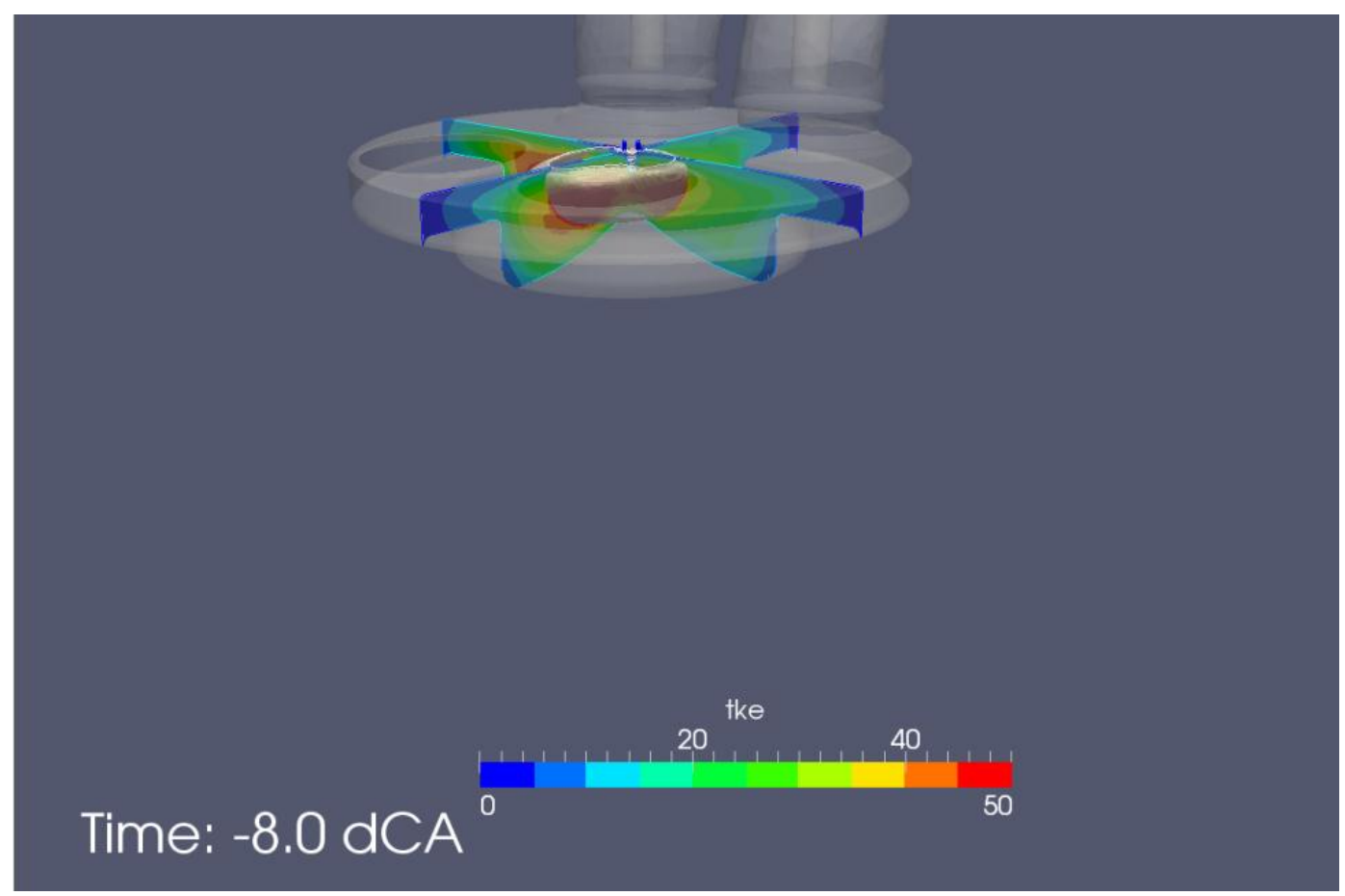

Figura 121 - Frente de chama e energia cinética turbulenta a $8^{\circ}$ APMS ("Mexhat”).

Com base na análise comparativa dos resultados mostrados nesta seção, foi possível definir a geometria da câmara de combustão mais propensa ao controle de detonação e à 
queima mais eficiente, ou seja, a configuração com pistão conhecido por "Chapéu Mexicano" (denotado por "Mexhat") e classificado como pistão 5 durante o trabalho de desenvolvimento.

\subsubsection{Análise Experimental das Câmaras de Combustão “Chapéu Mexicano” e "Baseline".}

Após a construção do pistão definido como "Chapéu Mexicano", foi feita uma análise comparativa com o "Baseline" em um motor FEV monocilíndrico de pesquisa, o qual não seguiu rigorosamente as mesmas condições de ensaios realizados com o primeiro "Baseline" (mesma geometria) mostrado na Figura 102, pois os testes envolvidos visavam apenas a comparação experimental, sem necessariamente ter sido planejado com base nas simulações já feitas. De qualquer forma, esperou-se que as conclusões fossem as mesmas.

As provas foram realizadas sob as seguintes condições:

- Inicio das provas com IMEP de 10 bar;

- Realização de diluição da mistura até o motor atingir o COV (coeficiente de variância) de 3,5;

- Aumento da carga até o motor apresentar o índice de Knock de 1,5 bar;

- $50 \%$ de massa queimada ocorrendo entre $7^{\circ}$ e $9^{\circ} \mathrm{DPMS}$

- Motor operando na rotação de 1800 RPM (conforme aplicação no motogerador);

- Cargas de 10, 12, 14, 16, 17, 18, 19 e 20 bar de IMEP;

- $\quad$ Temperatura do ar de admissão entre $21,5^{\circ} \mathrm{C}$ e $27^{\circ} \mathrm{C}$;

- Pressão barométrica entre 94,8 kPa e 95,2 kPa;

Os equipamentos utilizados foram:

- Motor monocilíndrico de pesquisa FEV;

- Analisador de combustão AVL Indimodul;

- Dinamômetro Horiba DYNAS-3 LI250. 


\subsubsection{Resultados Experimentais}

A Figura 122 ilustra um comparativo entre a câmara de combustão 'Baseline" e a “Chapéu Mexicano” em relação ao ângulo de queima para diferentes diluições da mistura ar/combustível. Usualmente descartam-se os primeiros e os últimos $10 \%$ de massa queimada e mede-se entre $10 \%$ e $90 \%$ de massa queimada como sendo o ângulo efetivo de queima. Com este critério, não houve uma diferença significativa no ângulo de queima para as duas configurações no IMEP de 10 bar, havendo, entretanto, um aumento no grau de diluição da mistura para o "Chapéu Mexicano", uma vez que se procurou atingir o máximo de diluição possível, respeitando o limite de COV de 3.5.

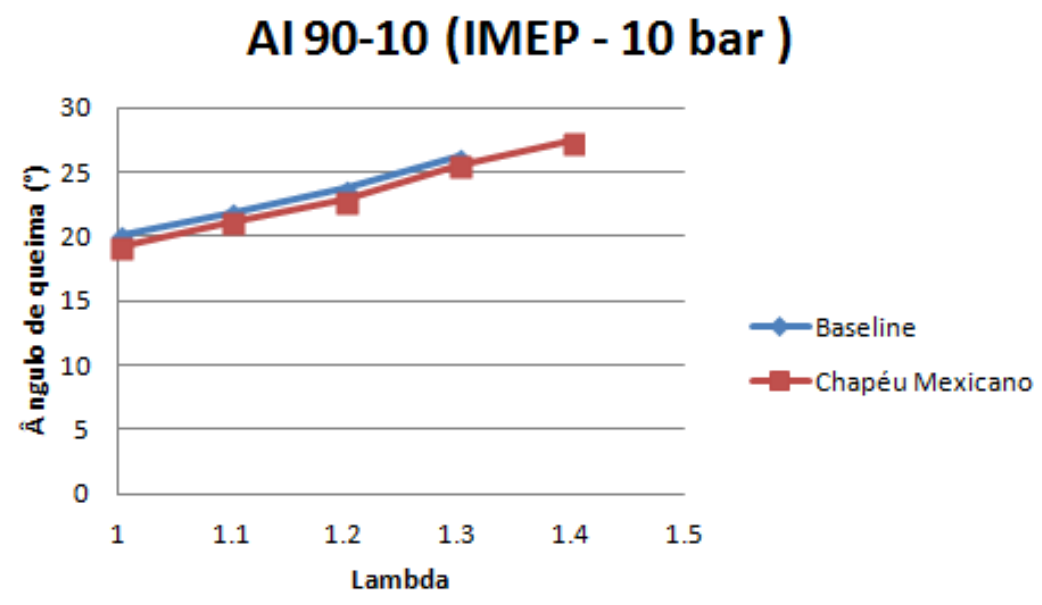

Figura 122 - Ângulo efetivo de queima.

Para o IMEP de 18 bar (Figura 123), que é a condição simulada anteriormente, confirmou-se o previsto, ou seja, a queima mais rápida para a configuração do "Chapéu Mexicano", com a observação do fato de poder se expandir o grau de diluição da mistura. Esse comportamento foi explicado, com base nas figuras Figura 99 e Figura 121, como sendo resultado da energia cinética turbulenta mais intensa nas proximidades da vela de ignição. $\mathrm{O}$ 
ressalto no centro do pistão também contribuiu com a capacidade de se trabalhar com misturas mais pobres, tornando a queima mais eficiente.

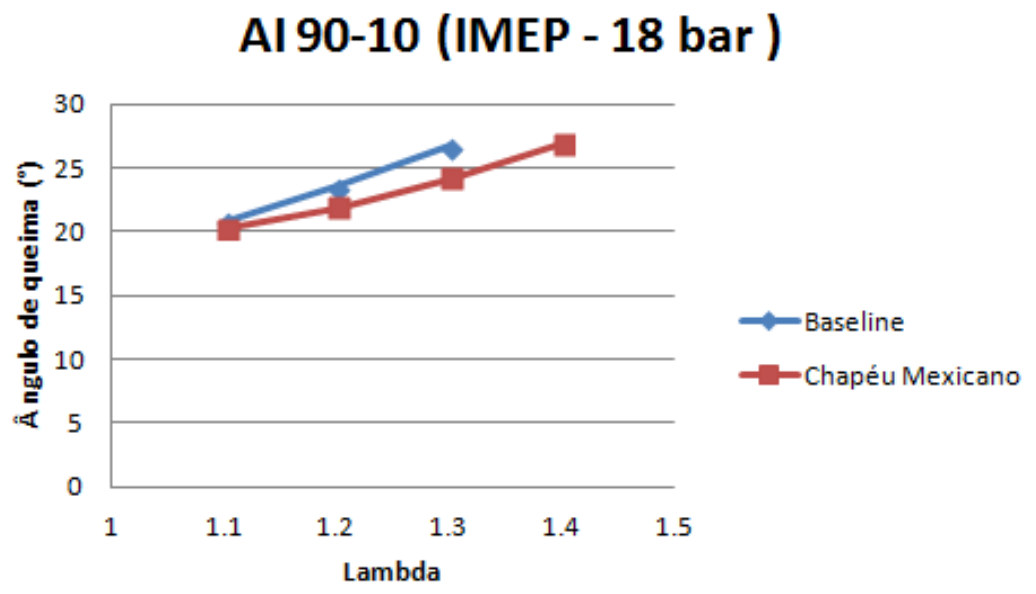

Figura 123 - Ângulo efetivo de queima.

De forma coerente com o observado com o ângulo de queima para 10 bar de IMEP, não houve ganho de rendimento significativo para as mesmas condições de ensaio para ambas as geometrias, nem mesmo incremento de rendimento para o ponto de maior diluição atingido pela configuração do "chapéu mexicano" (Figura 124).

\section{Rendimento Indicado (IMEP - 10 bar )}

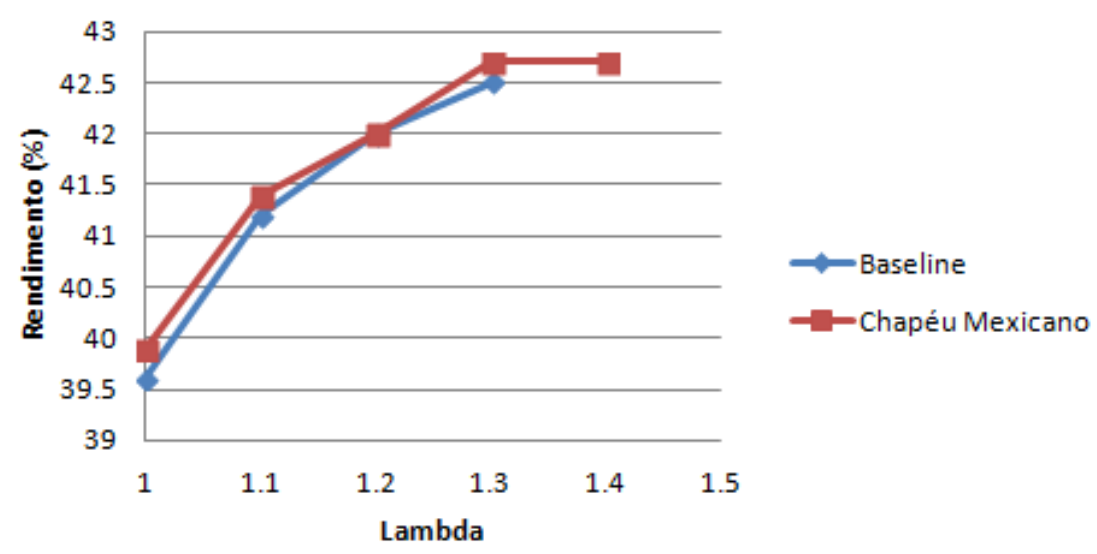

Figura 124 - Rendimento indicado. 
Para o IMEP de 18 bar, confirmou-se o previsto em simulação, ou seja, esperava-se por um aumento no rendimento indicado proveniente de uma queima mais rápida e também mais estável (Figura 125).

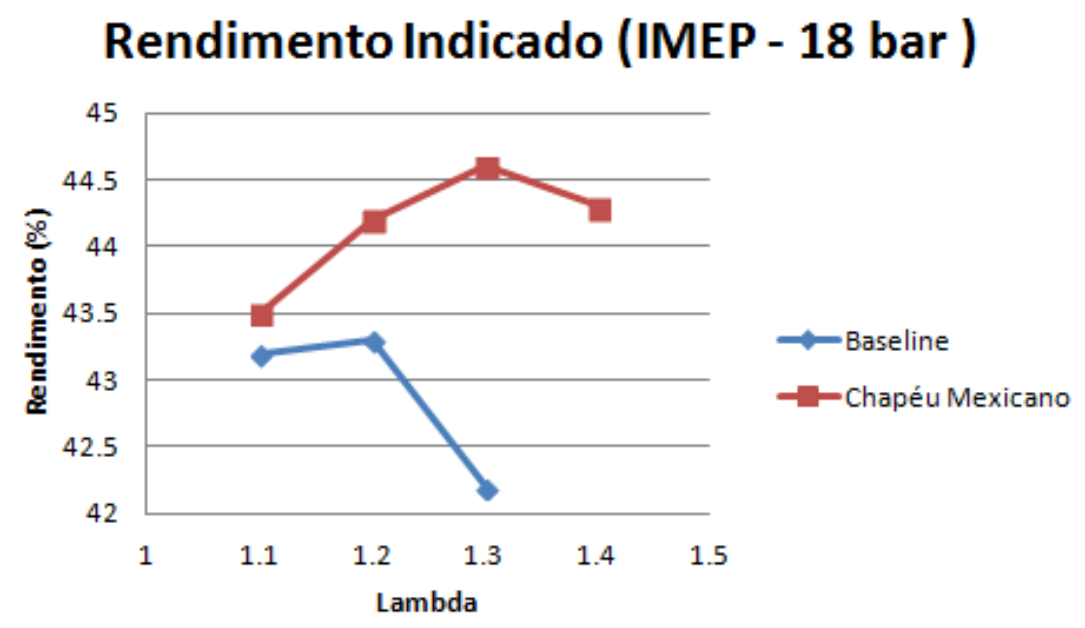

Figura 125 - Rendimento indicado.

\subsubsection{Análise da Formação da Mistura Ar/Combustível (simulação 3D)}

Após definição da geometria da câmara de combustão a ser construída, faz-se necessária uma investigação do processo de formação de mistura desde a injeção de combustível no pórtico de admissão até o momento do disparo da centelha, a fim de verificar o grau de homogeneidade da mesma, e confrontá-lo com a hipótese de mistura homogênea utilizada na simulação 3D.

Uma extensão desta análise consistiu no estudo para a aplicação do conceito em um motor multicilíndrico, pois havendo refluxo de combustível para o pleno de admissão, a distribuição de mistura para cada cilindro passa a ser diferente, influenciando nos dados experimentais coletados no motor real utilizado. 
A Figura 126 ilustra perfis da câmara de combustão com a geometria selecionada na cavidade do pistão e dos dois pórticos de admissão, sendo um característico para geração de "swirl" e outro de fluxo direto.

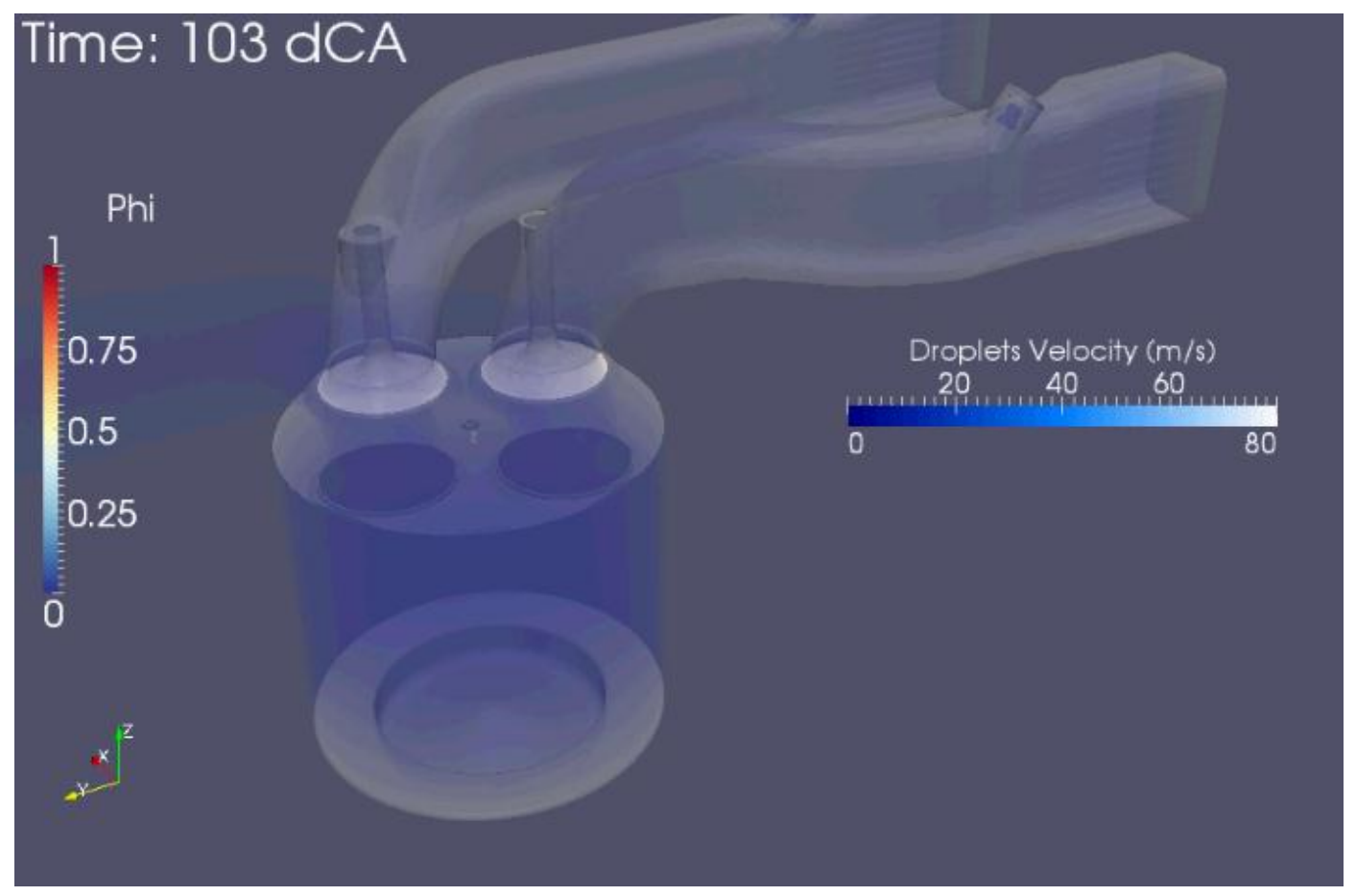

Figura 126 - Câmara de combustão e pórticos de admissão.

Uma sequência de eventos será mostrada a partir da ilustração acima, onde há duas escalas coloridas. A escala horizontal representa a velocidade de escoamento das gotas de combustível líquido, cujo intuito é observar tanto o escoamento em direção ao cilindro quanto de observar a dinâmica de depósito de filme líquido nas paredes dos pórticos de admissão e sua evaporação. A escala vertical representa o fator " $\Phi$ ” para a mistura de ar e vapor de combustível no interior do cilindro, permitindo a análise de sua distribuição momentos antes do disparo da centelha. O tempo de simulação está representado em ângulos do virabrequim, sendo $0^{\circ}$ e $720^{\circ}$ os valores que marcam a fase de expansão, escolhidos de forma conveniente, pois o foco é a injeção de combustível no pórtico de admissão, o qual começa 
(antecipadamente) na fase de expansão e não de admissão. Usualmente, a expansão se dá a $360^{\circ}$ para a simulação de combustão.

A Figura 127 mostra dois jatos de combustível injetados simultaneamente nos dois pórticos de admissão, permidindo visualizar a formação de filme líquido nas paredes dos mesmos, enquanto que parte da injeção se atomiza em gotas de diversos tamanhos e outra passa diretamente para a fase de vapor. Uma observação importante é que o direcionamento do jato não se deu como usual, em direção à face da válvula de admissão, devido ao fato da base do pórtico utilizado ser originária de uma aplicação Diesel, onde apenas ar flui pelo mesmo, no caso em questão, foi feita uma flange para acoplar o injetor ao pórtico e ao pleno de admissão.

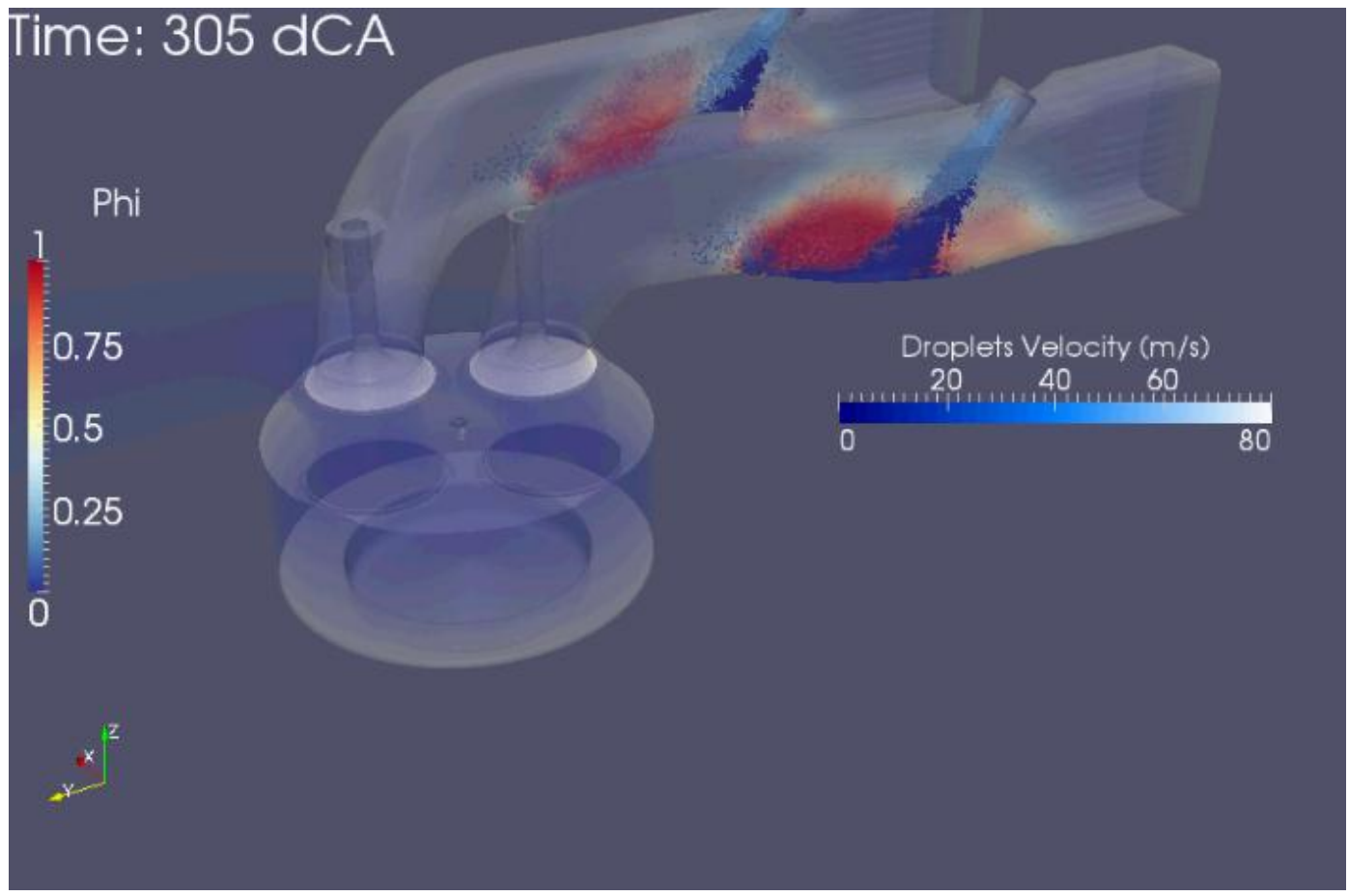

Figura 127 - Injeção de combustível.

Observa-se, também, a distorção do jato de combustível durante o cruzamento de válvulas, ou seja, enquanto a válvula de descarga está aberta simultaneamente com a de admissão. O refluxo de gases queimados no pórtico de admissão provenientes do ciclo 
anterior provoca, não só essa distorção, mas um retorno para o pleno de admissão de parte da mistura, o que também é observado experimentalmente por meio do equipamento de visualização óptica.

Uma importante observação pode ser feita a partir da análise das figuras Figura 128 e Figura 129, onde se pode notar que, para o primeiro ciclo, o efeito de distorção do jato durante o cruzamento de válvulas é marcante, enquanto que para três ciclos posteriores, já com a simulação convergente, não só numericamente, mas também em eventos (regime), esse efeito de distorção não fica evidente para a condição de operação simulada. O vapor de combustível remanescente do ciclo anterior parece influenciar nesse fenômeno, uma vez que não se espera que esse fato seja decorrente de problemas de convergência numérica, pois foi definida curta variação angular para cada "time step" $\left(0,1^{\circ}\right.$ do virabrequim) associado ao alto número de iterações por "time step" a fim de garantir convergência em cada um deles.

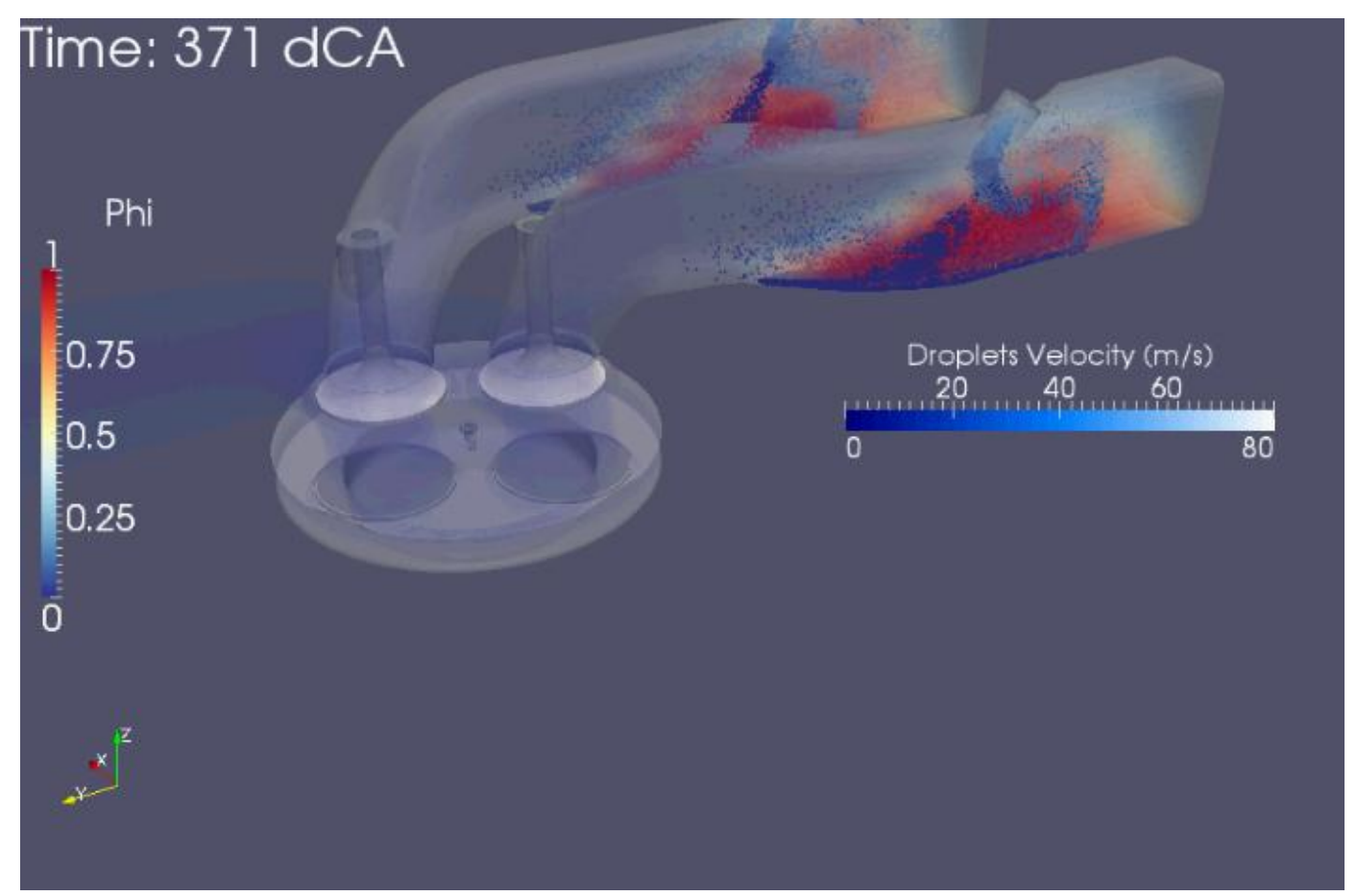

Figura 128 - Distorção do jato de combustível. 


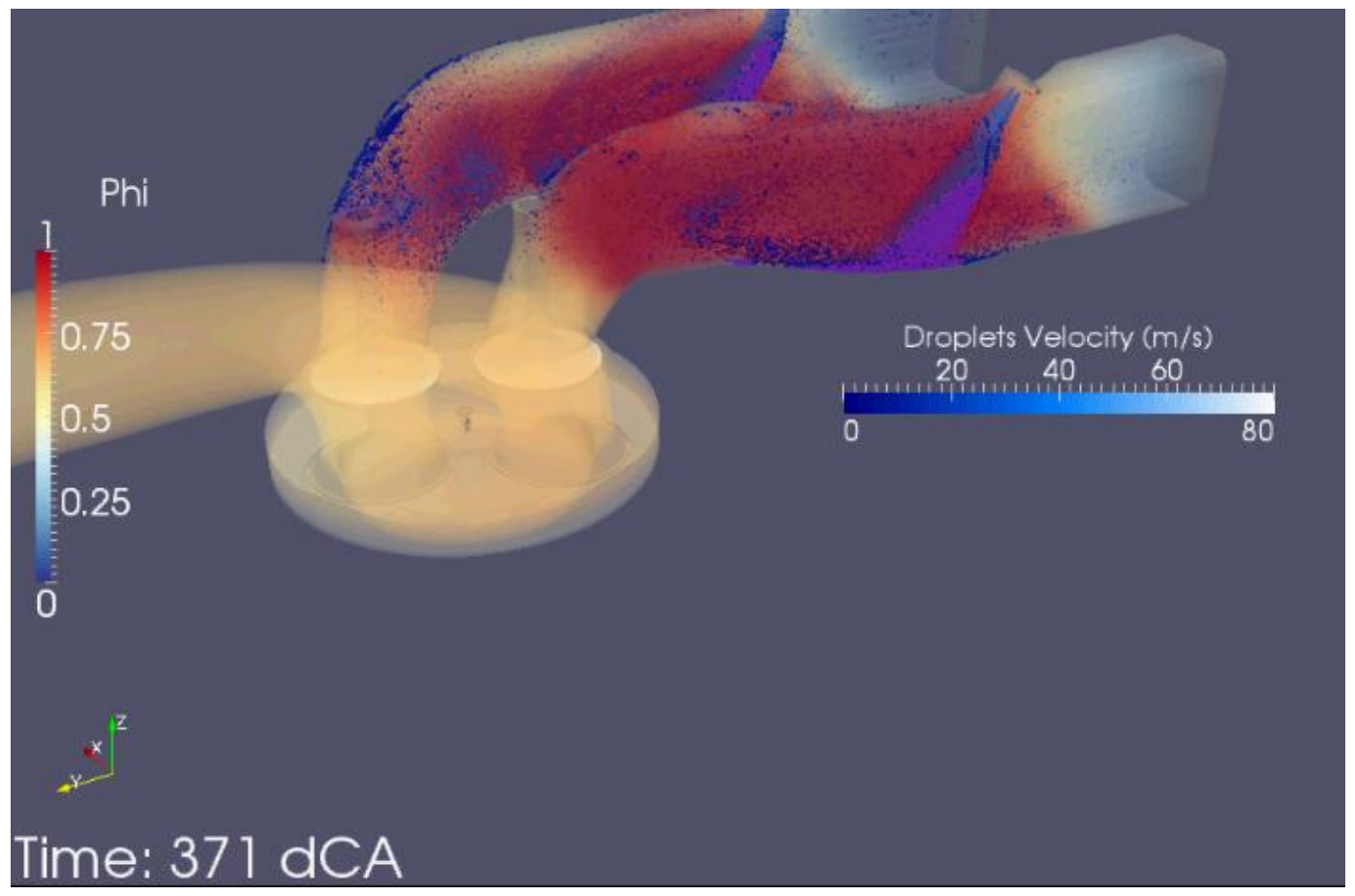

Figura 129 - Distorção do jato de combustível.

Próximo do momento de fechamento da válvula de admissão, pode-se observar (Figura 130) que o filme fluido depositado na base do pórtico diminuiu significativamente, entretanto grande depósito é notado nas paredes laterais, sendo mais acentuado no pórtico de "swirl". 


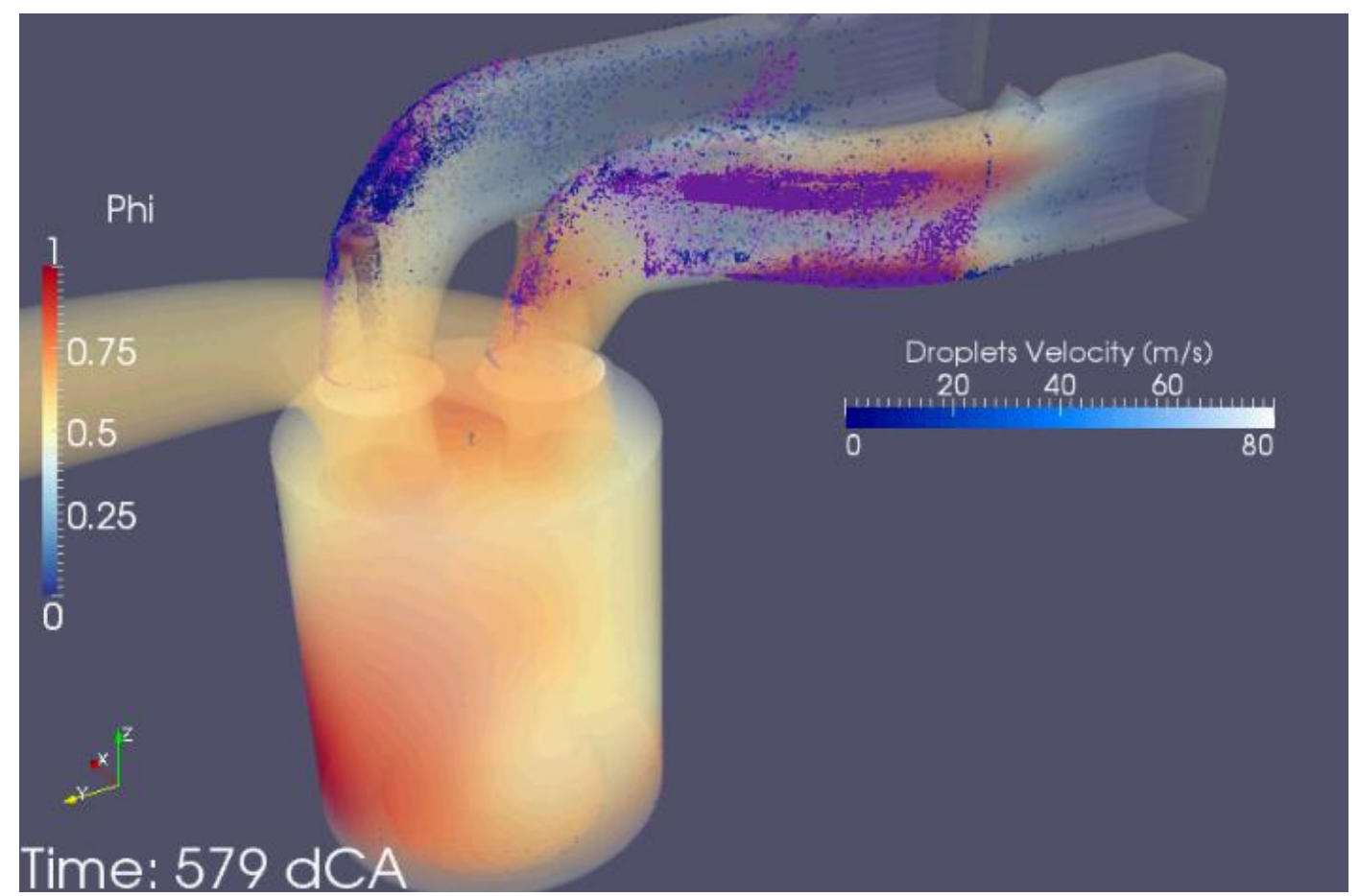

Figura 130 - Fechamento da válvula de admissão.

Na sequência, a Figura 131 ilustra a posição do pistão no momento do disparo da centelha. No pórtico, o processo de evaporação do filme líquido fica evidente. Em relação à câmara de combustão, qualitativamente parece haver somente vapor de combustível e o valor de $\Phi$ dentro do esperado. 


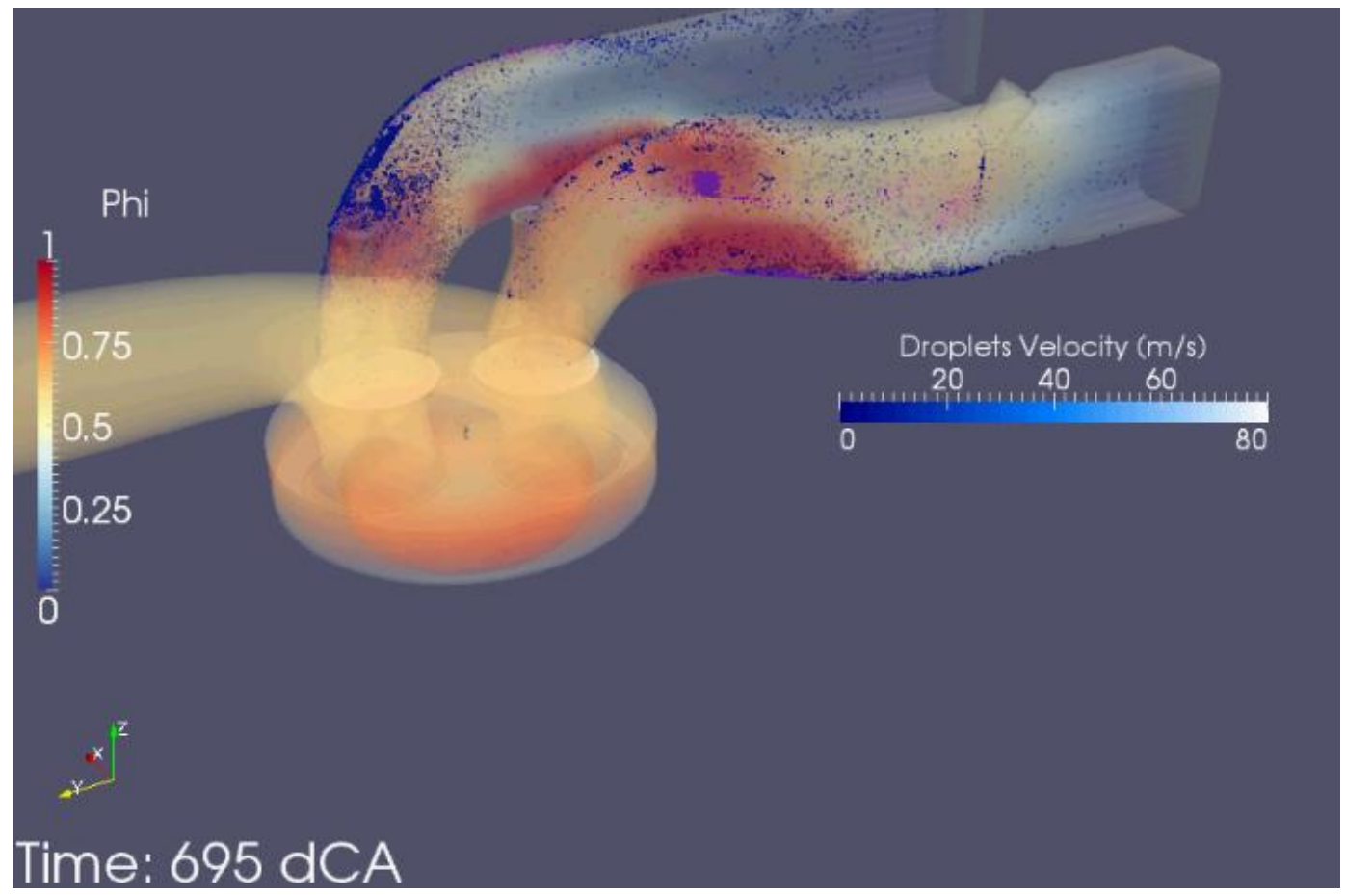

Figura 131 - Momento de ignição (25 APMS).

Com o fechamento da válvula de admissão em cada pórtico, observa-se que parte da mistura não chega ao interior do cilindro, ficando alí armazenada para o próximo ciclo. Quando em regime, não há perdas por esse efeito, já que o que ficará para o próximo ciclo foi igualmente recebido do anterior. Esta observação também sugeriu a adequação do melhor momento de injeção para cada condição de carga do motor.

Uma condição imposta ao modelo de simulação é que todo o combustível esteja na fase de vapor no momento do disparo da centelha, e conforme desejado, observa-se a evaporação completa das gotas até o final do curso de compressão, ilustrado na Figura 132. 


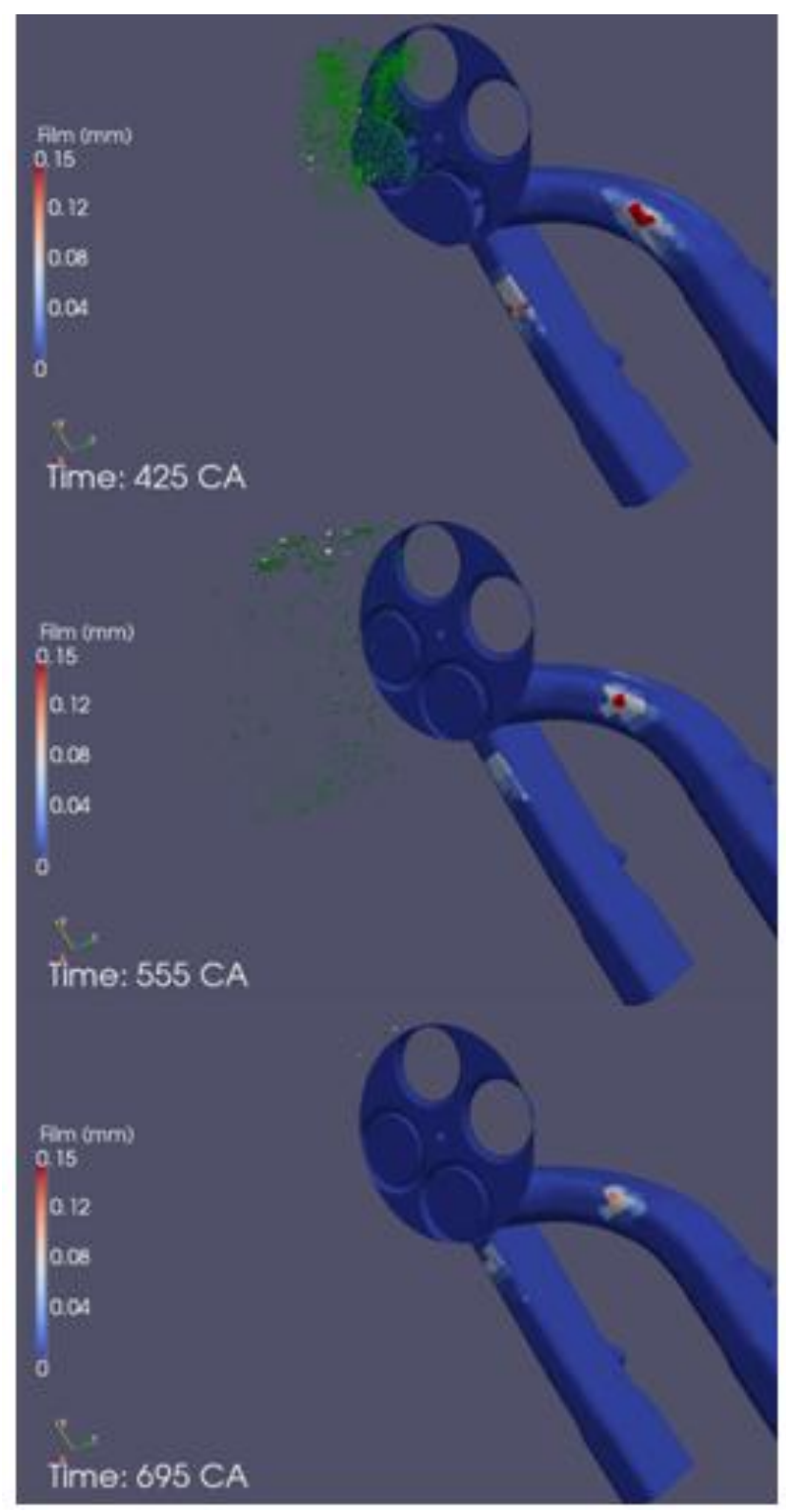

Figura 132 - Evaporação das gotas.

Outra condição é a de homogeneidade da mistura, ou seja, uma distribuição uniforme do valor de $\Phi$ no interior do cilindro antes do disparo da centelha (Figura 133). O que se pôde observar, de forma quantitativa, é o fato de que o seu valor esperado foi encontrado na região da vela de ignição, conforme desejado, entretanto uma estratificação foi observada nos cantos da cavidade da câmara no pistão, sugerindo que ainda há o que se trabalhar em termos de formação de mistura, no tocante à injeção de combustível, geração de turbulência pelos 
pórticos de admissão e geometria de câmara de combustão para auxiliar a fase final desse processo.

De qualquer maneira, a distribuição não homogênea de $\Phi$ não provocou diferenças mensuráveis que comprometessem a assertividade do modelo simulado em relação aos dados experimentais, conforme considerado anteriormente.

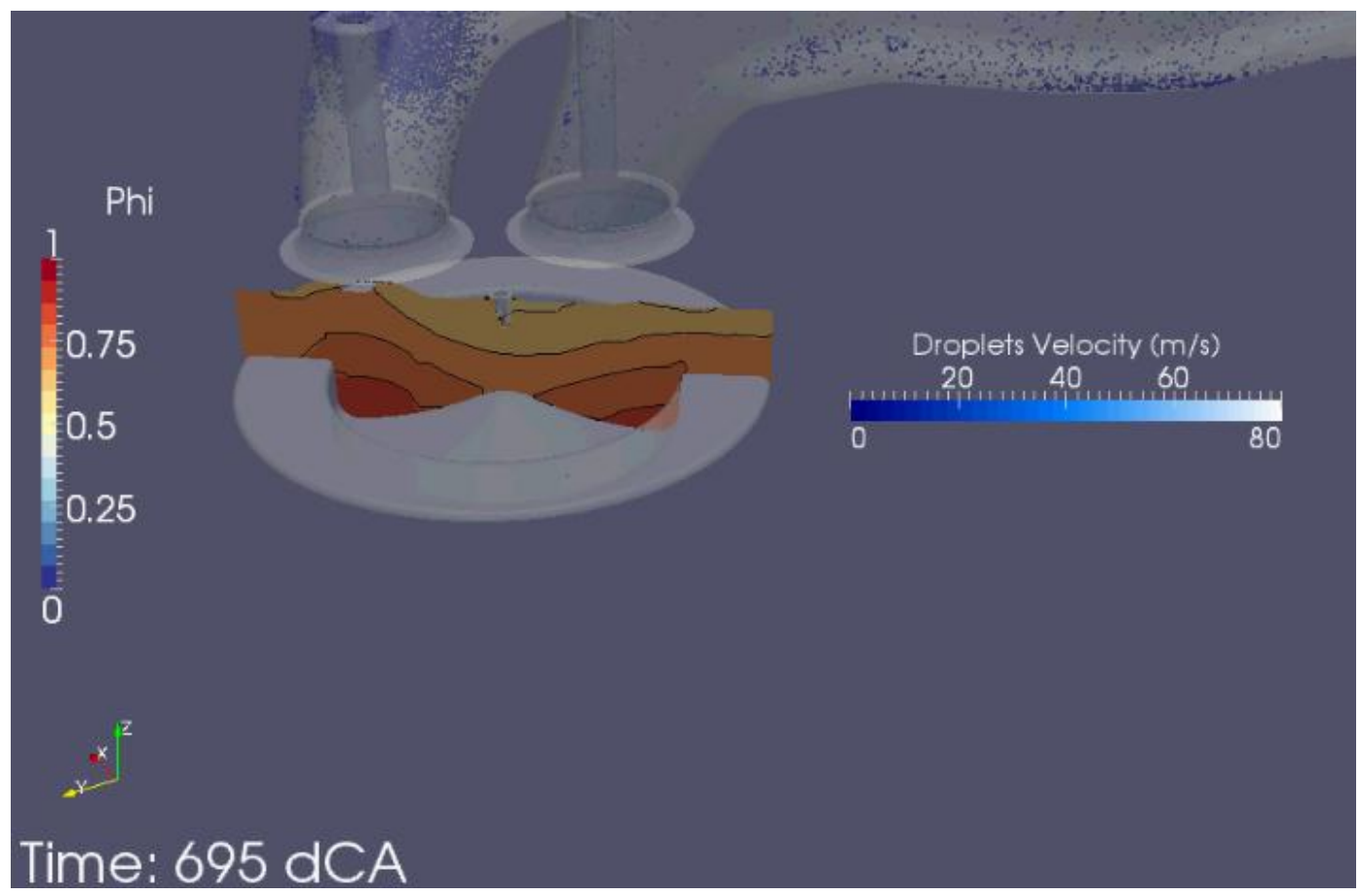

Figura 133 - Distribuição de $\Phi$ na câmara de combustão.

$\mathrm{Na}$ busca de melhor qualidade de formação de mistura ainda no pórtico de admissão, foram investigadas outras possibilidades de jatos de combustível, a partir de variações da abertura angular do cone de injeção e do redirecionamento dos mesmos.

Redirecionando-se o jato de combustível de modo a ficar mais voltado para a válvula de admissão, mesmo que isso não signifique atingi-la diretamente, esperou-se diminuir o efeito de refluxo em direção ao pleno de admissão.

Outra configuração avaliada foi a diminuição do ângulo do cone de injeção a fim de gerar menor volume de combustível se chocando com as paredes laterais dos pórticos de admissão. 
Na sequência, as figuras Figura 134, Figura 135, e Figura 136 ilustram o efeito da inclinação do injetor na formação de filme líquido e no refluxo em direção ao pleno de admissão.

Fica evidente a menor tendência de refluxo da mistura ar / combustível para o pleno de admissão no caso da aplicação do injetor mais inclinado em direção à válvula de admissão., assim como menor formação de filme líquido.

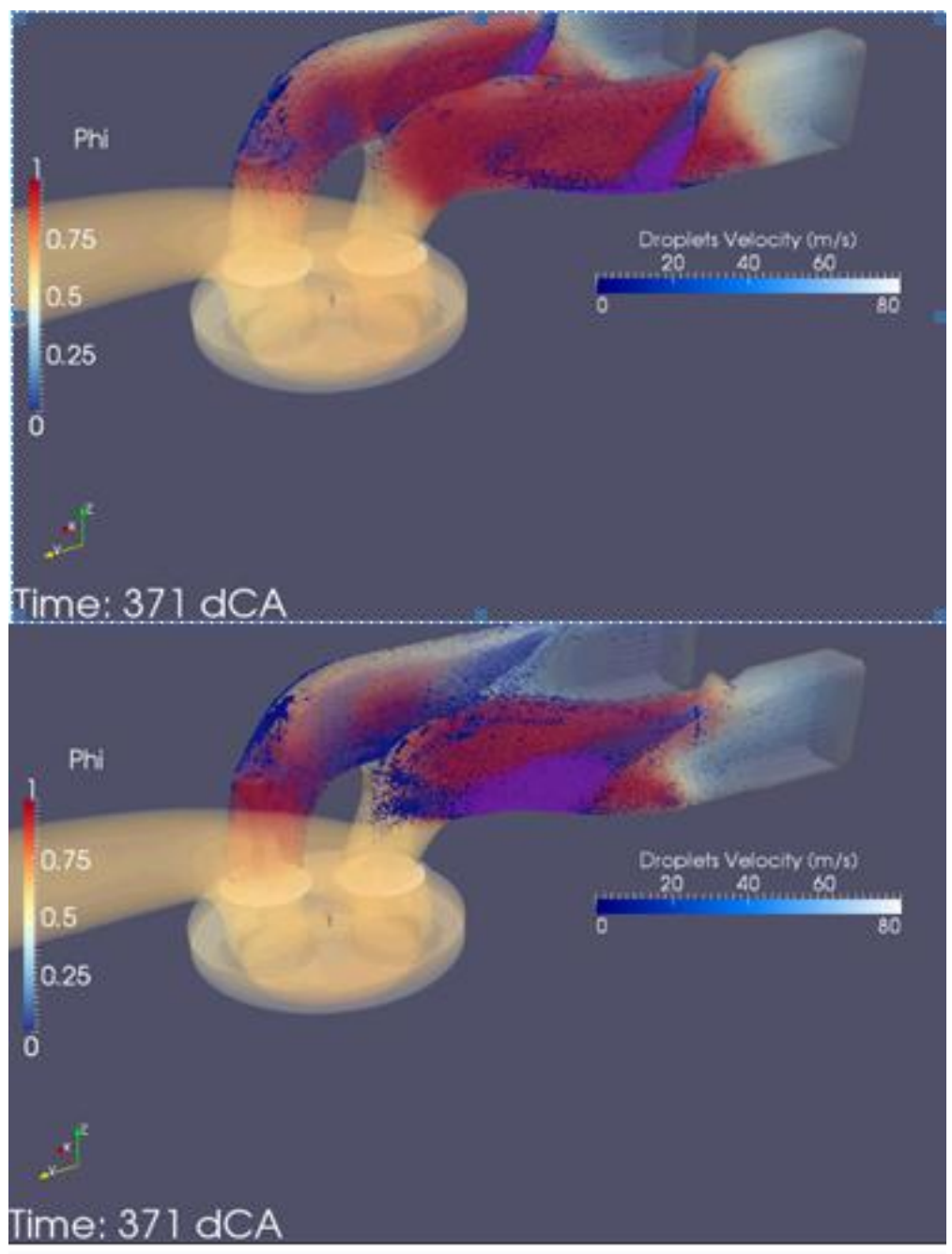

Figura 134 - Efeito da inclinação do injetor (durante cruzamento de válvulas). 


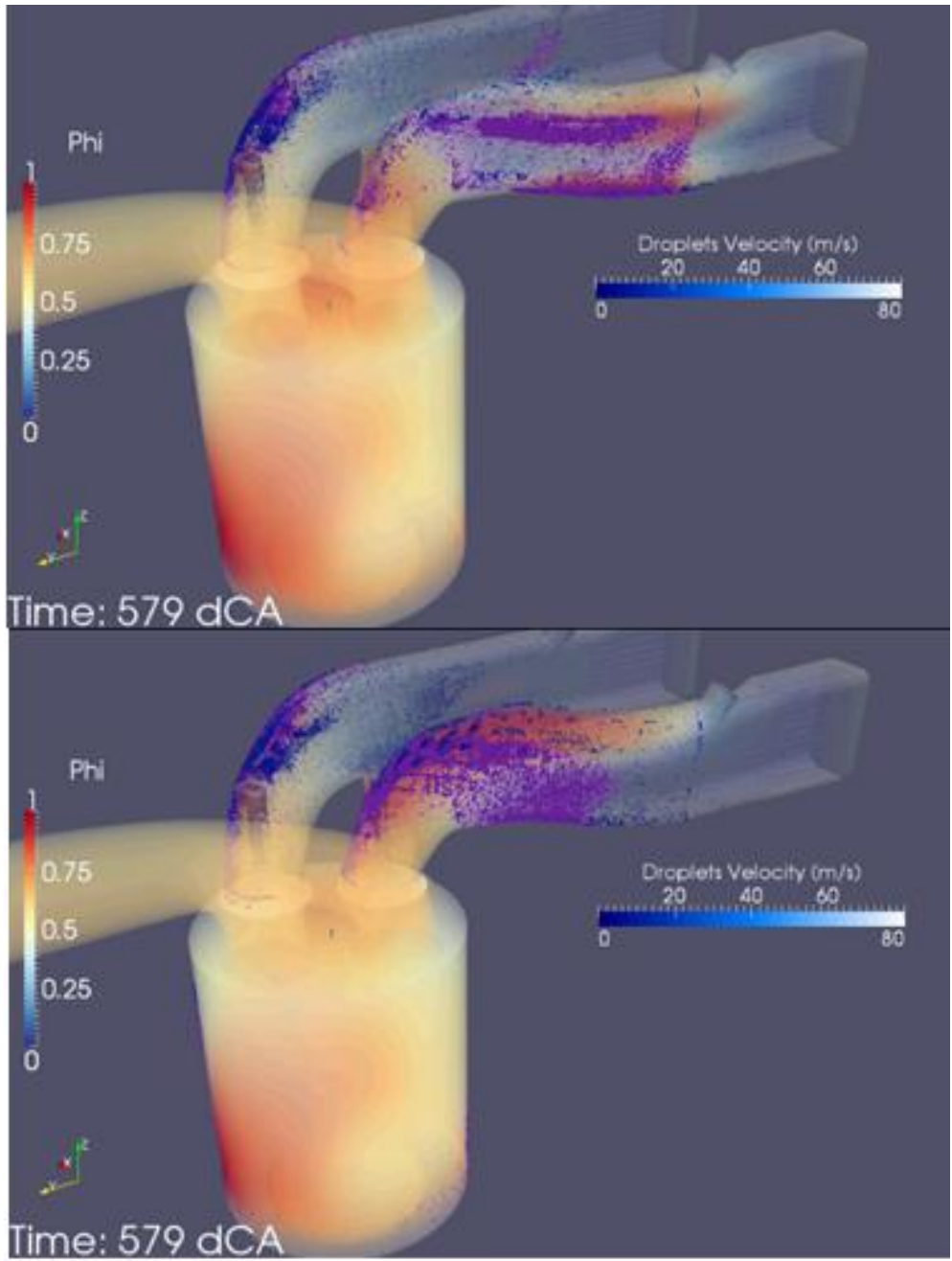

Figura 135 - Efeito da inclinação do injetor (término da admissão). 


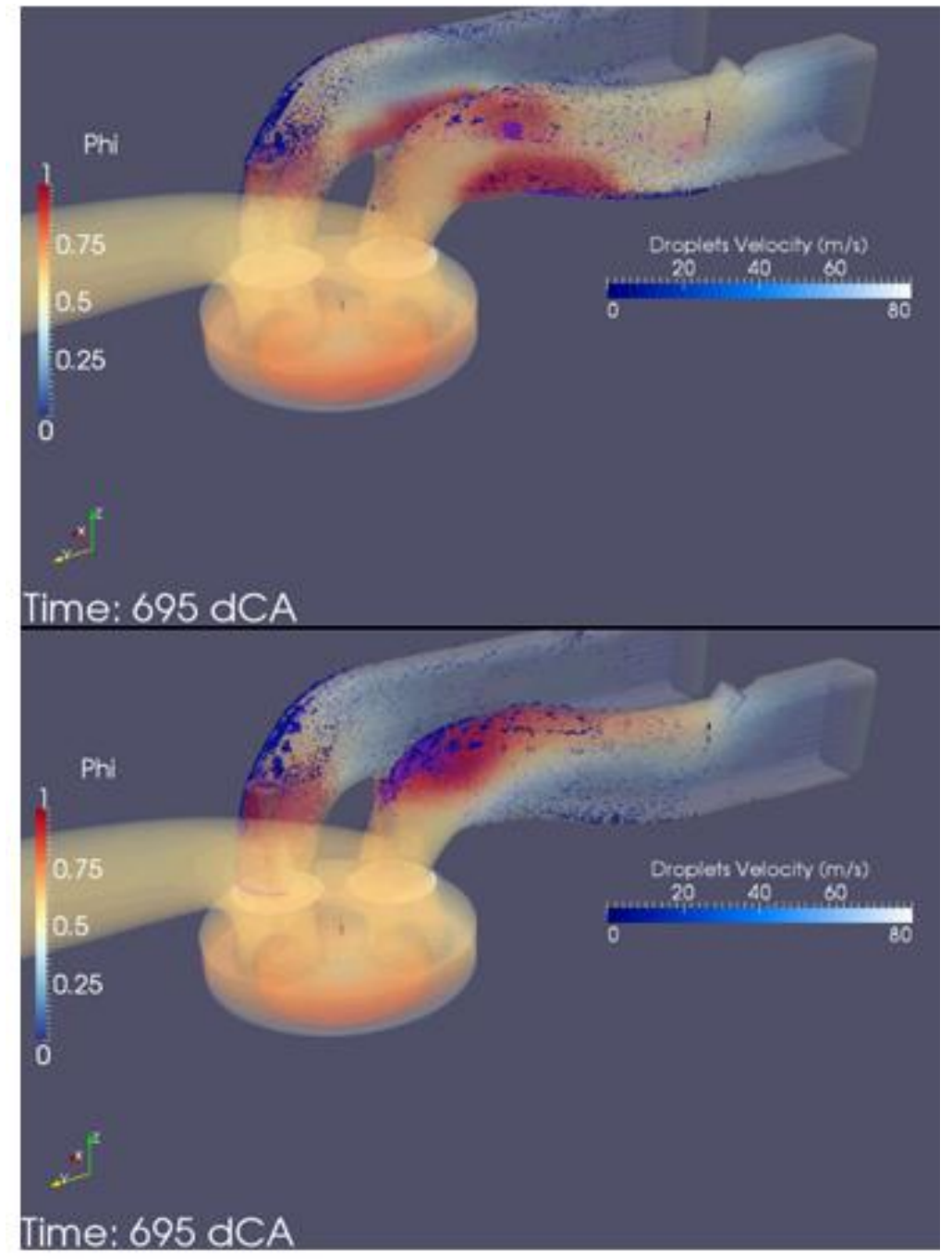

Figura 136 - Efeito da inclinação do injetor (momento da ignição).

A sequência a seguir, desde a Figura 137 até a Figura 142, repete as abordagens anteriores com ângulo do cone de injeção diferente. 


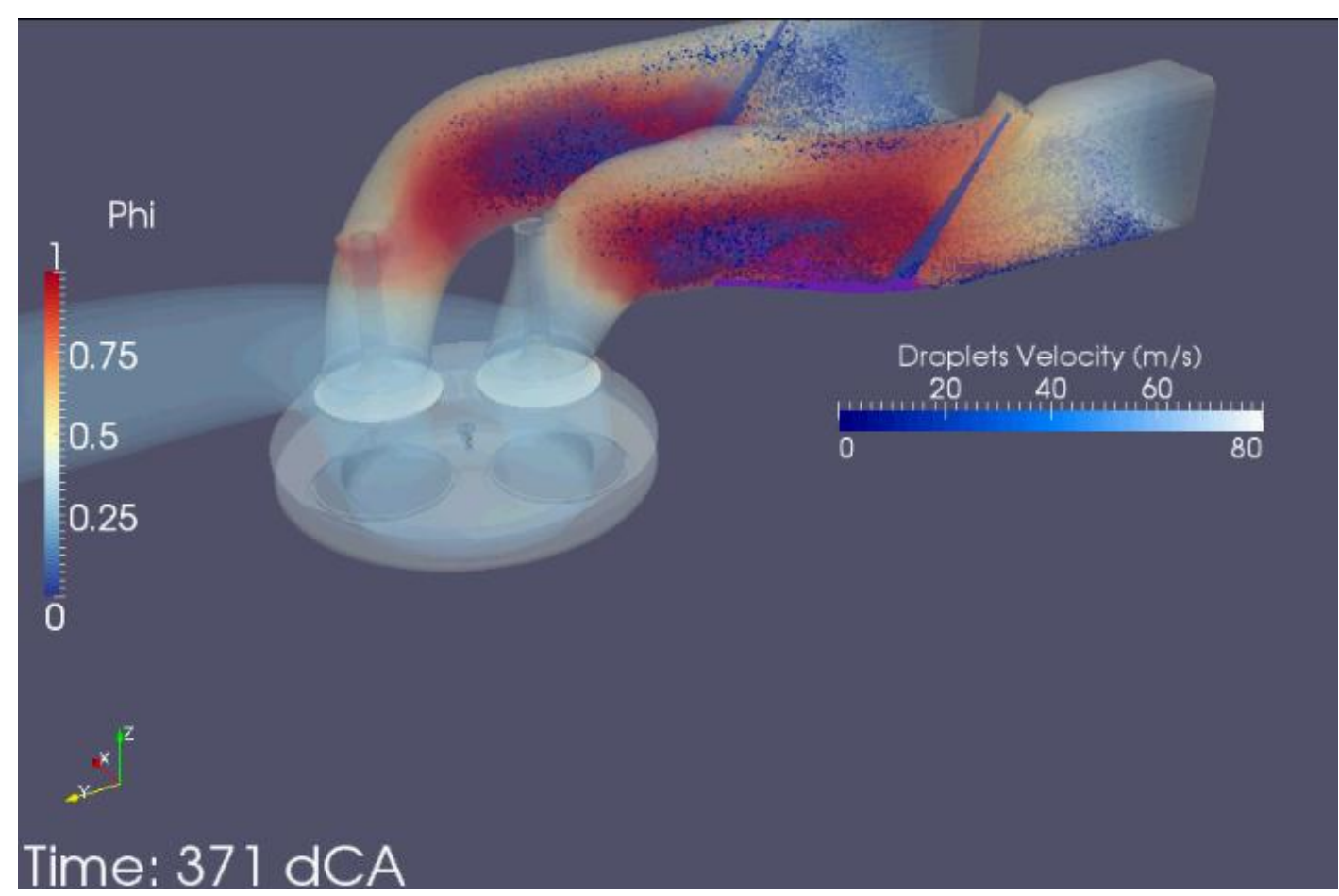

Figura 137 - Efeito do ângulo do cone de injeção (371 graus).

$\mathrm{Na}$ análise das figuras Figura 138 e Figura 141, fica evidente a distorção do jato de combustível durante o atraso do fechamento da válvula de admissão para as diferentes inclinações dos seus injetores. Na imagem da Figura 139, também se pode observar claramente que parte do jato de combustível foi empurrada em direção ao pleno, que fica imediatamente na face de entrada do pórtico. 


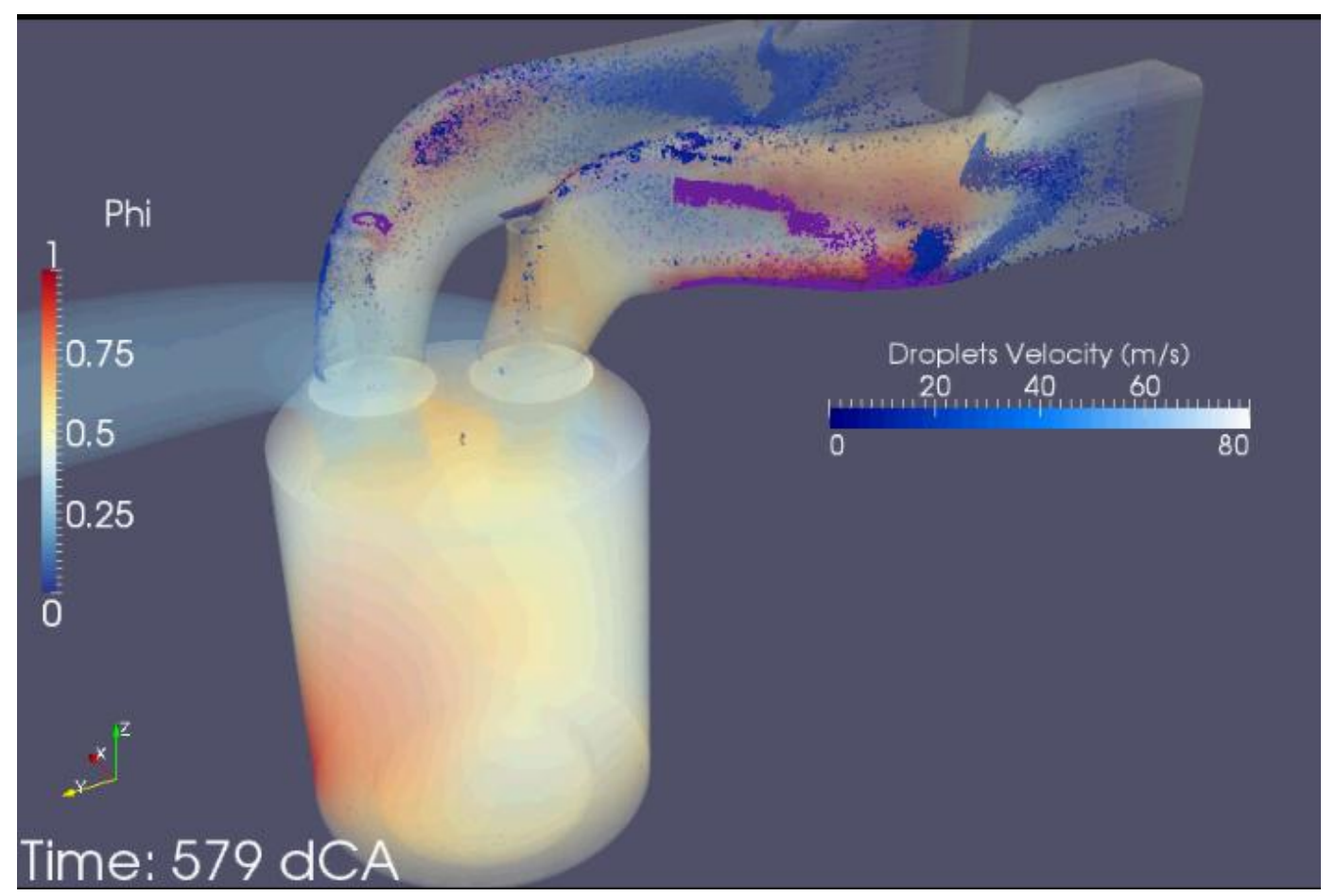

Figura 138 - Efeito do ângulo do cone de injeção (579 graus).

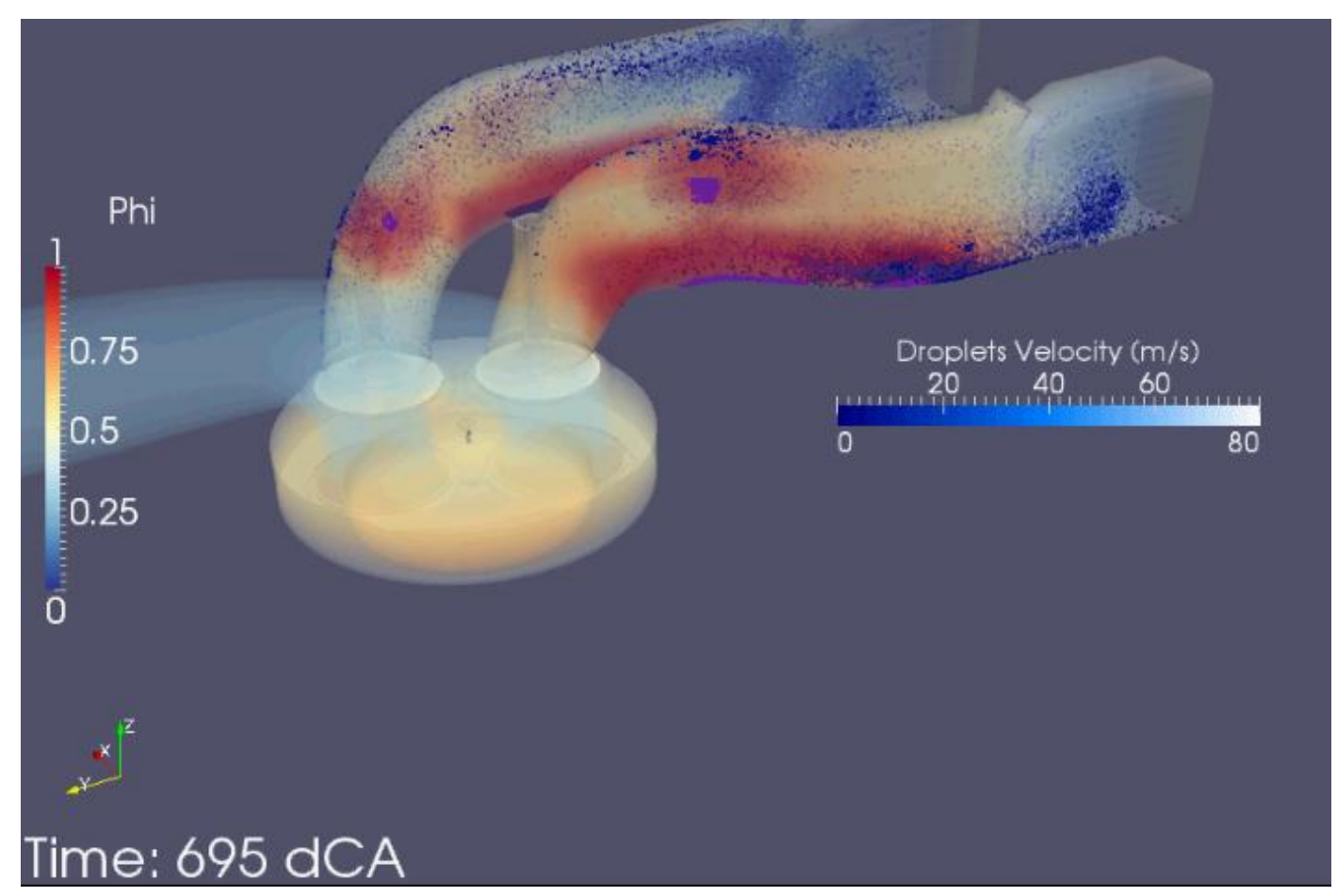

Figura 139 - Efeito do ângulo do cone de injeção (695 graus). 


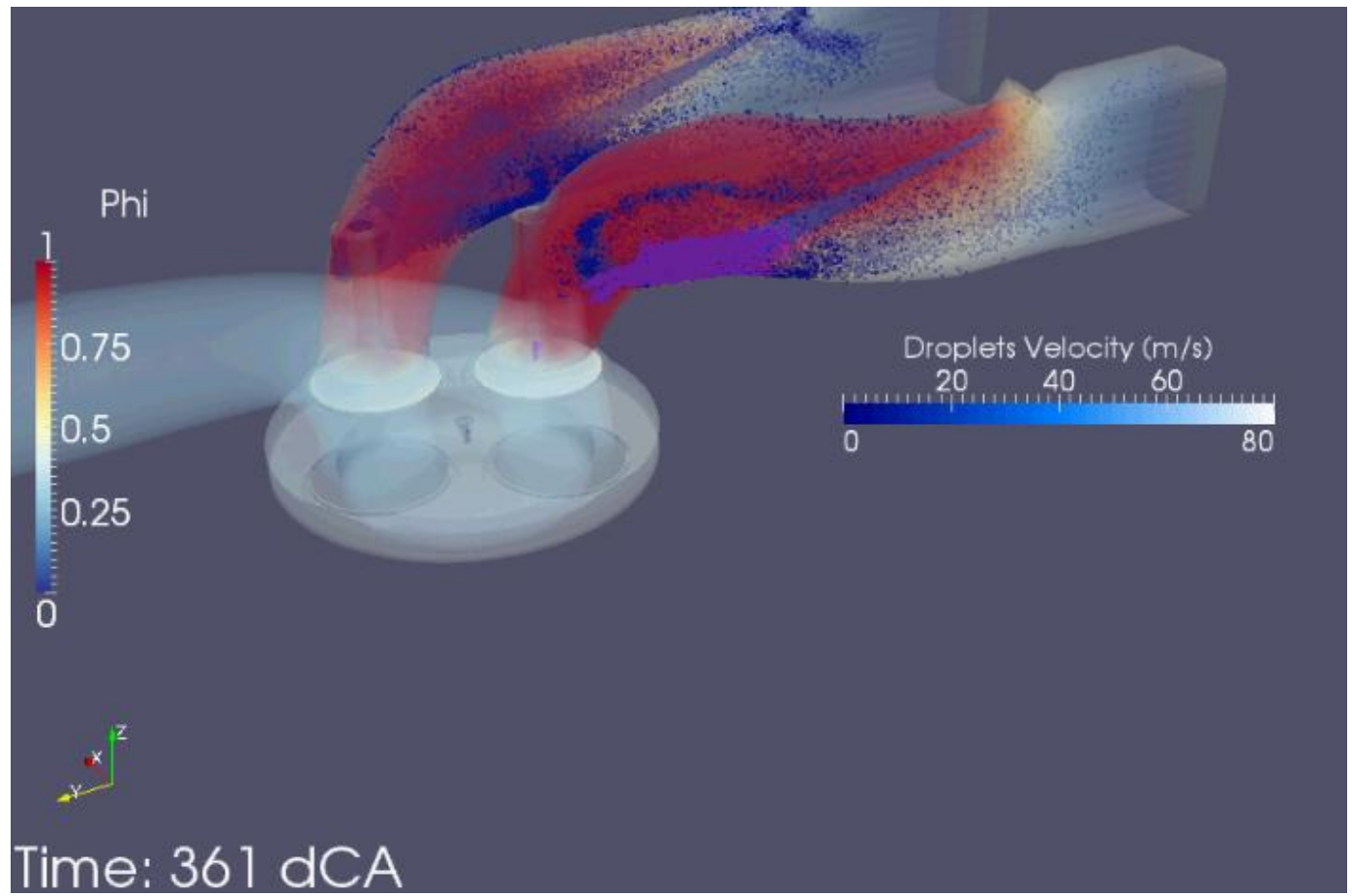

Figura 140 - Efeito do ângulo do cone de injeção com inclinação (361 graus).

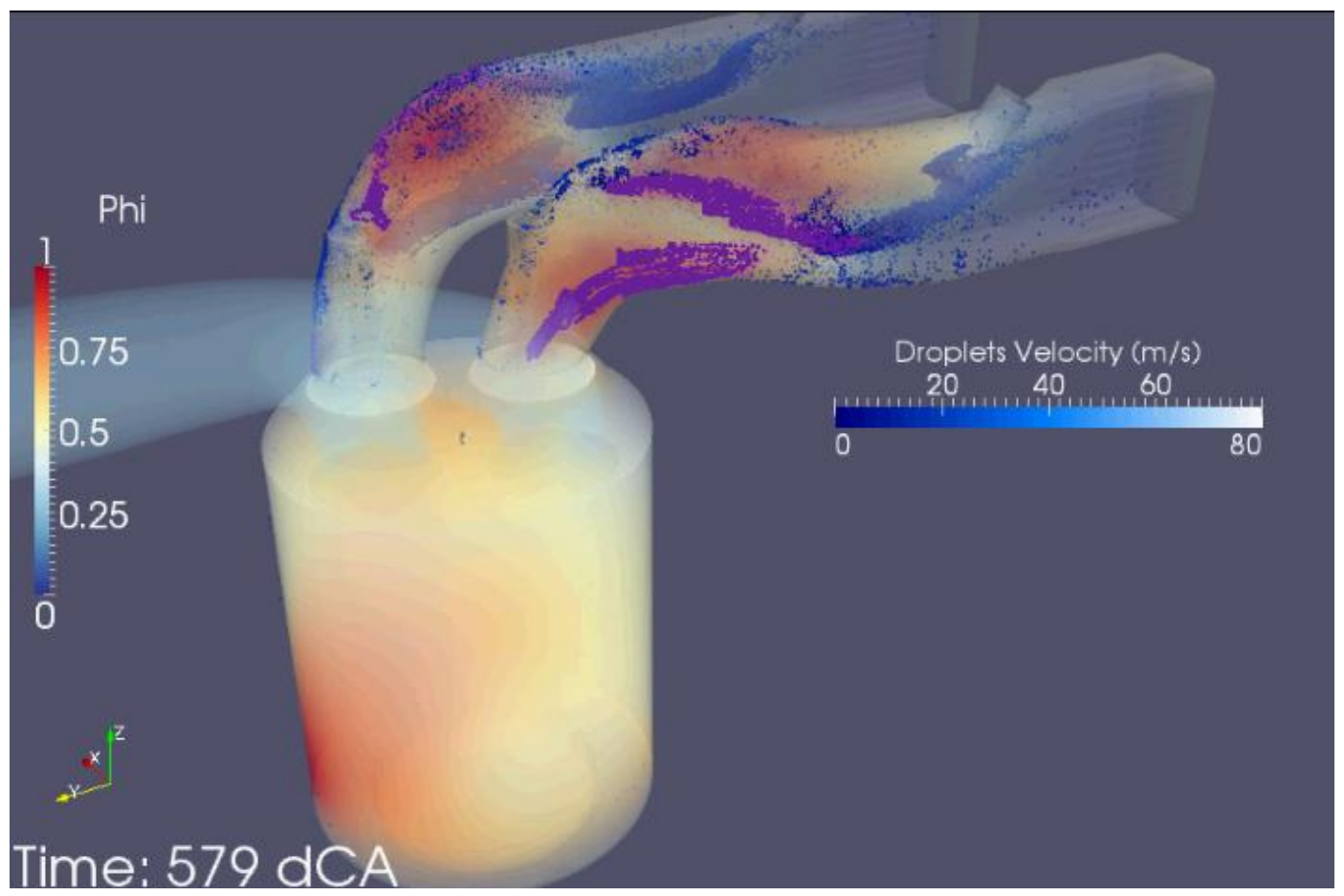

Figura 141 - Efeito do ângulo do cone de injeção com inclinação (579 graus). 


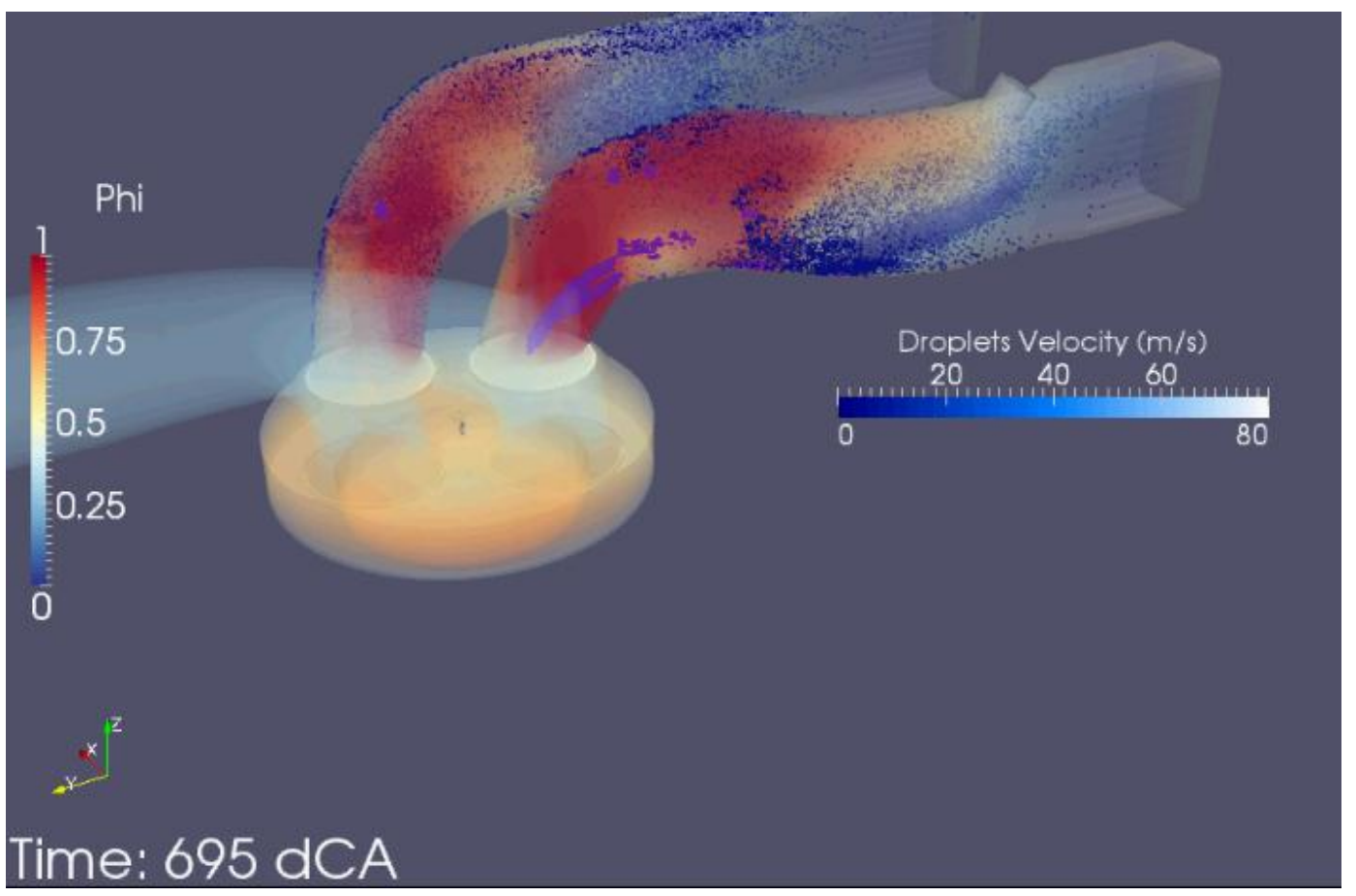

Figura 142 - Efeito do ângulo do cone de injeção com inclinação (695 graus).

Conforme citado anteriormente, foi feita uma análise experimental do refluxo de combustível para o pórtico de admissão par meio de instrumentação óptica, o que permitiu comparação com o previsto numericamente.

Para facilitar a compreensão, a Figura 143 ilustra, com uma visão frontal do duto de fluxo direto, a sequência adotada anteriormente para análise conforme sequências anteriores: cruzamento de válvulas, fechamento da válvula de admissão com retardo e momento da ignição. Na Figura 144, tem-se a comparação visual entre um momento inicial de injeção simulado e outro experimental, sendo esse bem representativo do ponto de vista qualitativo. $\mathrm{O}$ mesmo pode ser dito a respeito do momento referente ao cruzamento de válvulas, quando ocorre refluxo de combustível para o pleno, representado pela Figura 145. A Figura 146 também corrobora, de maneira definitiva o fato de haver refluxo de combustível, entretanto há outros efeitos que precisam ser considerados, pois a maior velocidade de escoamento no interior do pleno próximo ao cilindro 1 provoca mais arrasto de combustível do que para o cilindro 6, por exemplo. 


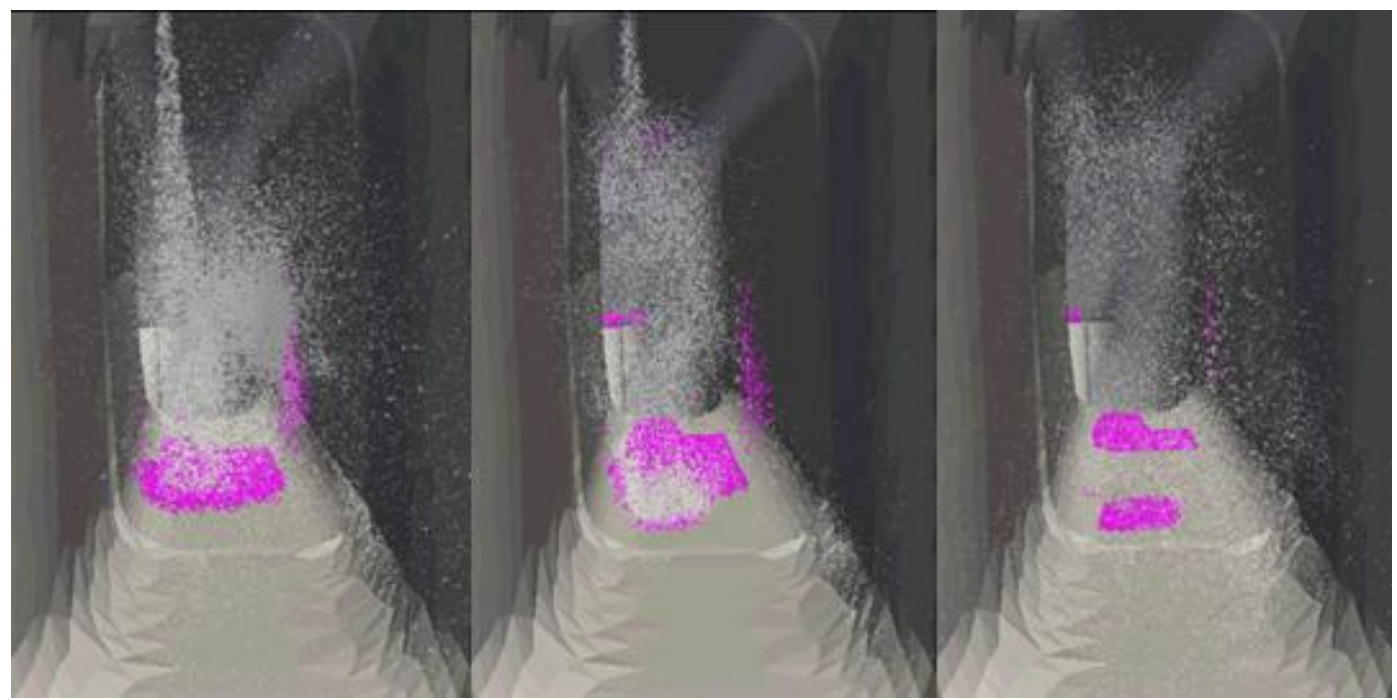

Figura 143 - Sequência 371, 579 e 695

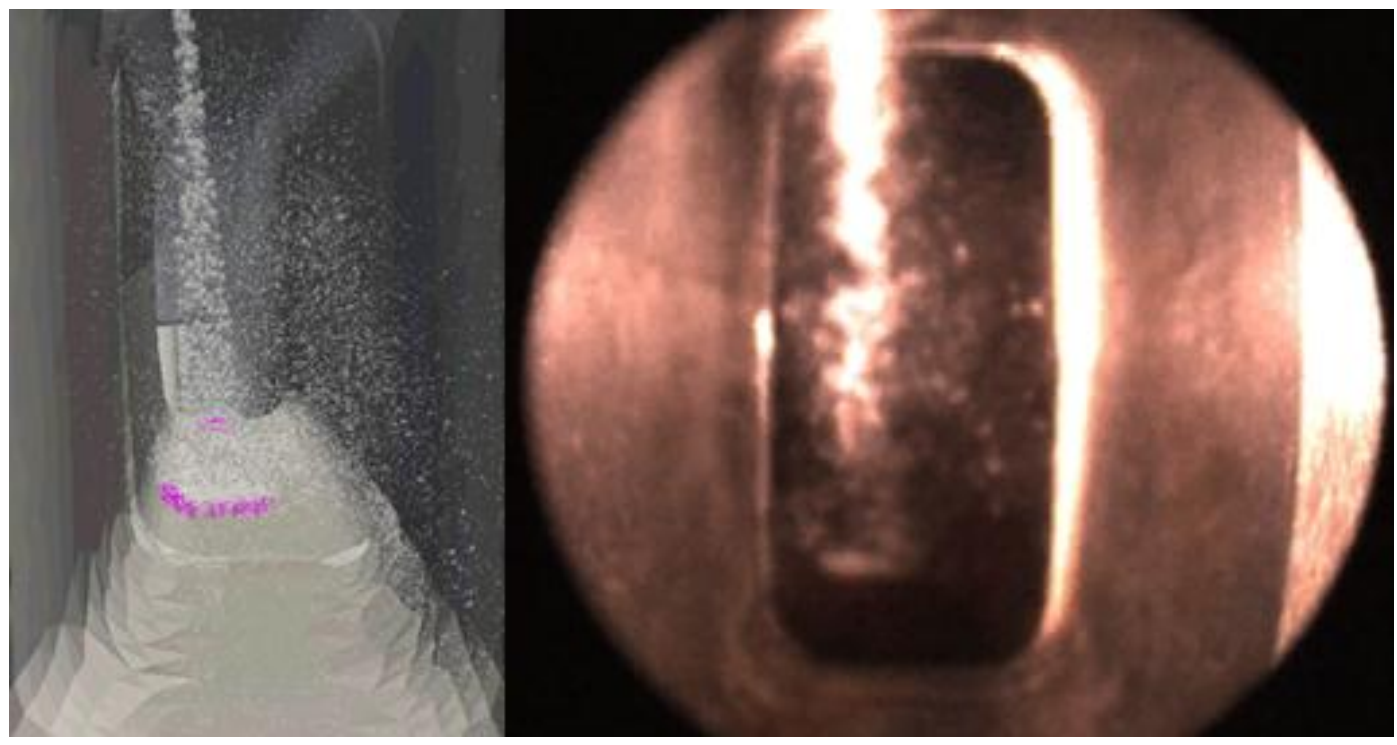

Figura 144 - Comparação entre simulação e experimentação. 


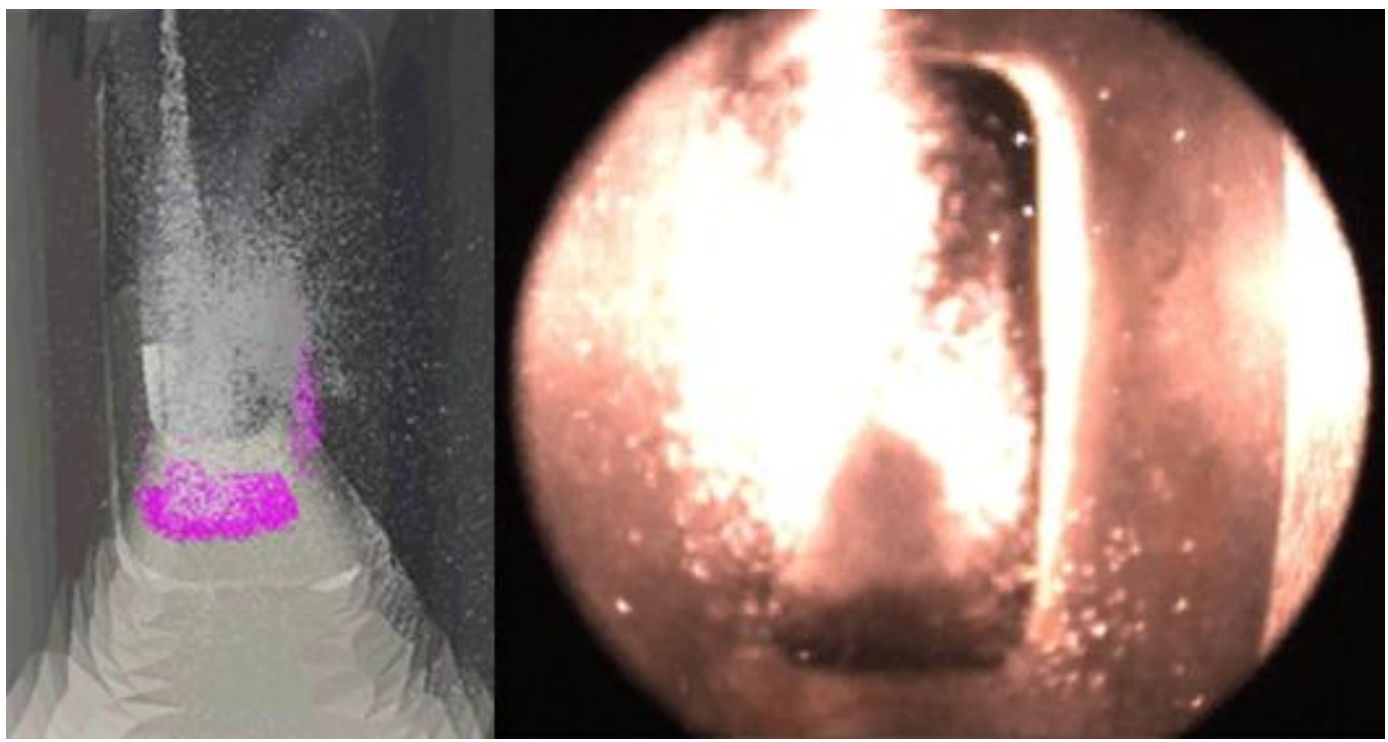

Figura 145 - Comparação entre simulação e experimentação.

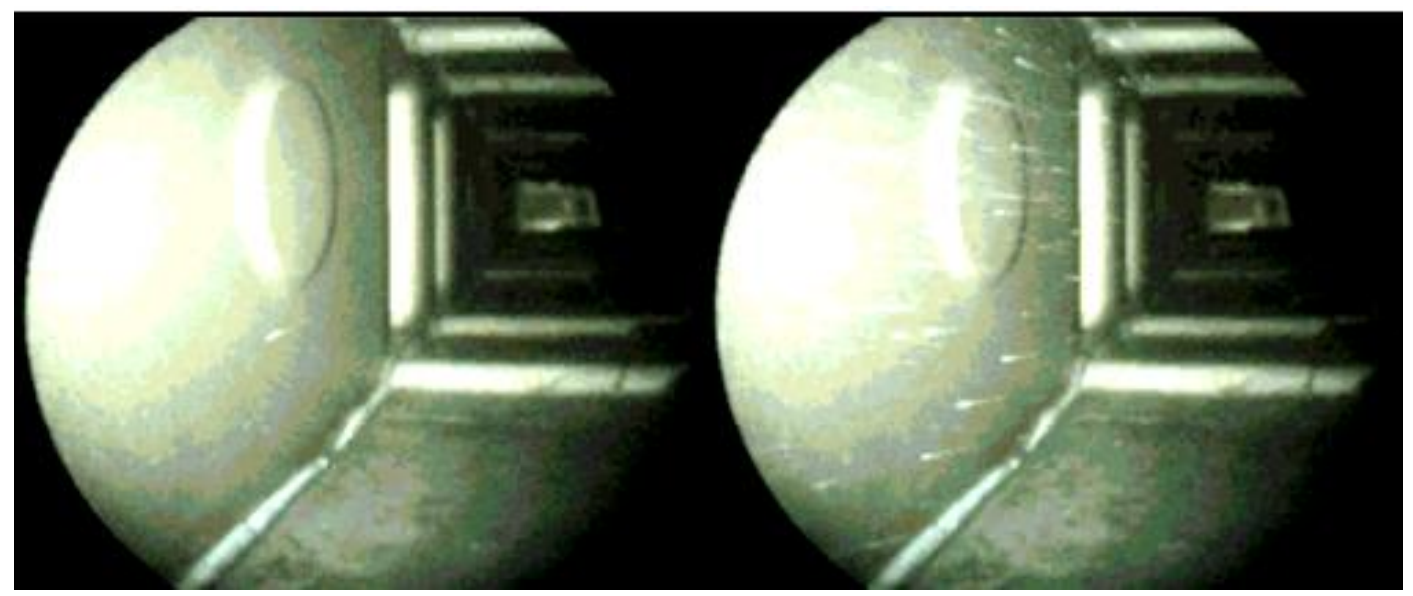

Figura 146 - Refluxo de combustível para o pleno (experimental).

Adequando-se a duração do tempo e momento de injeção à condição de carga do motor é possível minimizar a formação de filme líquido. Uma experiência feita para baixa carga e curta duração de injeção com válvula aberta possibilita ver tal efeito, conforme ilustrado na Figura 147 para injeção no pórtico de "swirl". Uma sequência de cinco fotos mostra a evolução do jato de combustível, e desde a primeira foto é visível o filme líquido remanescente do ciclo anterior, conforme previsto em simulações mostradas anteriormente. 


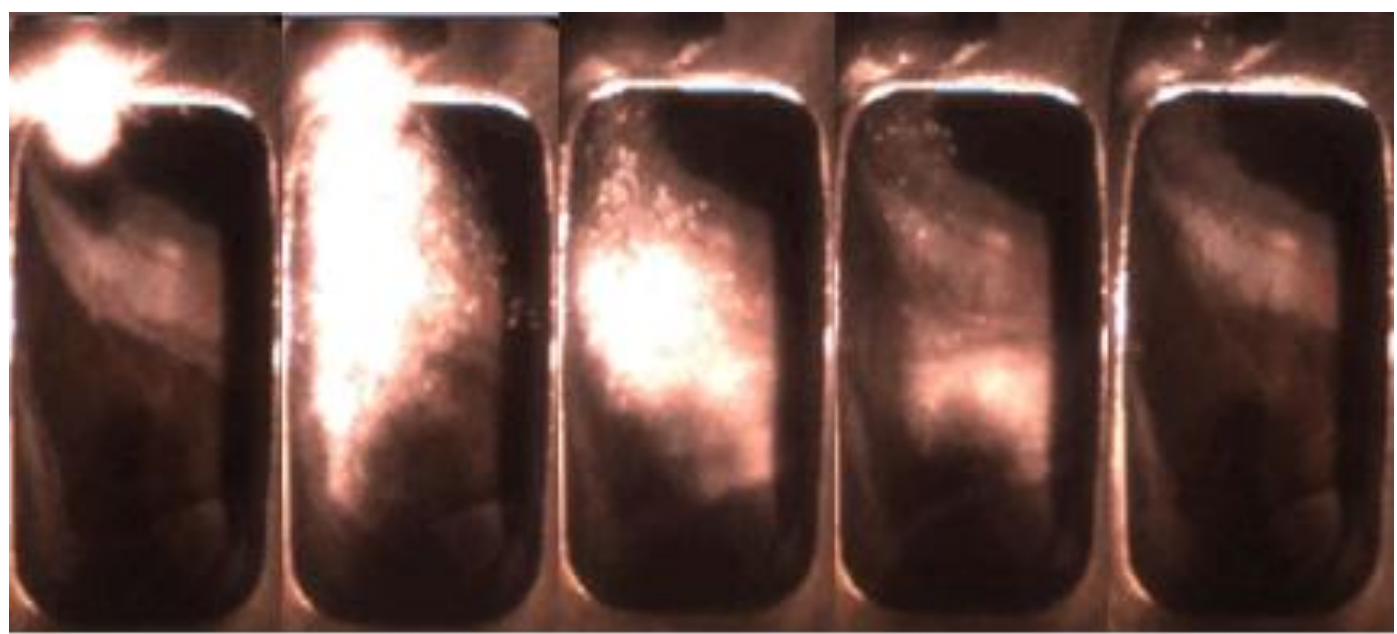

Figura 147 - Formação de filme líquido.

Os gráficos a seguir ilustram o comparativo entre as diferentes propostas para o perfil de injeção, conforme mostrado nas figuras anteriores. A porção de filme líquido depositada no pórtico de swirl ao longo de dois ciclos foi quantificada para permitir uma conclusão menos qualitativa do melhor perfil a ser adotado no motor real. Analisando-se os gráficos das figuras Figura 148 e Figura 149, fica evidente que o depósito de filme líquido é menos acentuado com a inclinação do injetor. Em contrapartida, a diminuição do ângulo do cone de injeção provocou o aumento do depósito.

É interessante que pela análise feita com base somente na Figura 135, não fica tão evidente o resultado da Figura 148. Entretanto, se forem observados atentamente os depósitos de filme líquido nas bases dos pórticos de "swirl" ilustrados na Figura 136, de fato é sugestivo que a maior parcela de formação de filme se dá na base e menos nas laterais. 


\section{Filme fluido no pórtico de admissão}

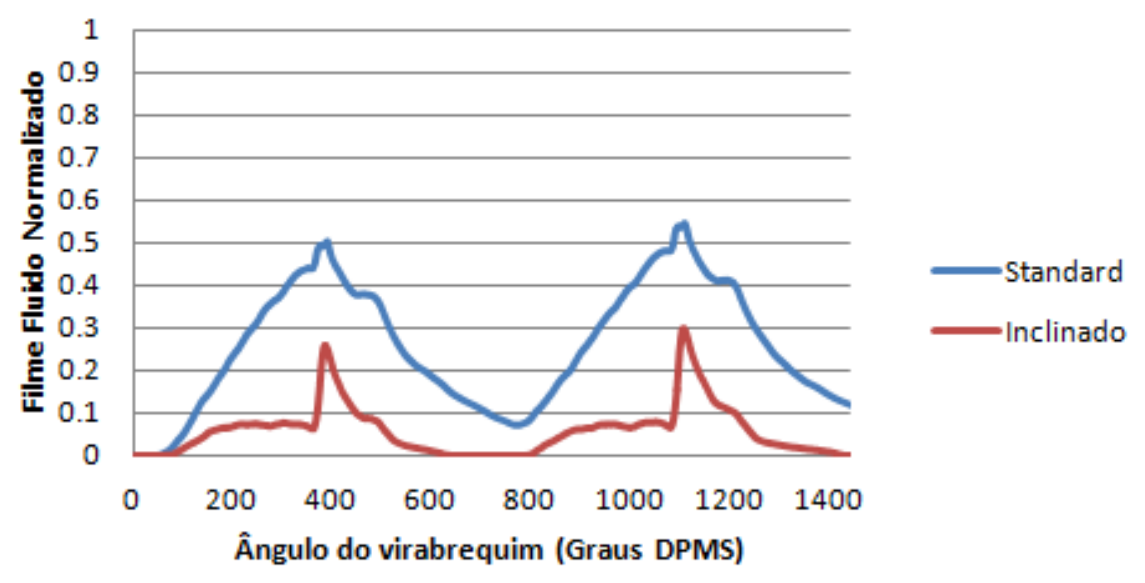

Figura 148 - Comparativo de quantidade de filme líquido.

\section{Filme fluido no pórtico de admissão}

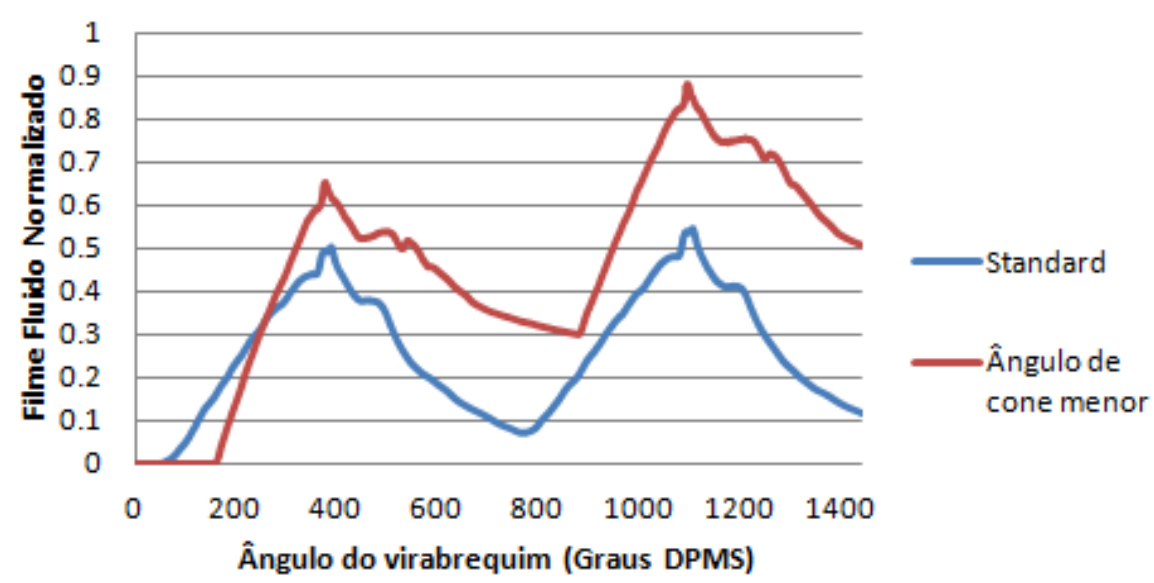

Figura 149 - Comparativo de quantidade de filme líquido.

De uma forma geral, a análise numérica do processo de formação de mistura se mostrou satisfatória para uma tomada de decisão segura sobre o tipo de configuração a ser adotada no motor multicilíndrico real, e para a compreensão de como o processo de formação de mistura pode influenciar o próprio projeto da câmara de combustão, por ser essa a responsável pela fase final desse processo para que haja garantias de que a relação ar / combustível esteja 
dentro dos limites préestabelecidos, mesmo com evidência de não homogeneidade da mistura na câmara de combustão. 


\section{CONCLUSÕES}

Conclui-se que:

- A utilização de ferramentas computacionais de simulação 1D e 3D se mostraram eficazes na redução de custo experimental e de tempo no desenvolvimento de uma câmara de combustão para um motor de combustão interna;

- O modelo de combustão de chama pré-misturada pôde ser utilizado com bastante representatividade em relação a um motor real operando no ciclo Otto;

- A simulação do processo de formação de mistura utilizando modelo de escoamento não reativo mostrou-se representativo ao se comparar com resultados experimentais, permitindo, assim, análise preditiva do grau de homogeneidade da mistura e da distribuição do fator $\Phi$ no interior do cilindro;

- Após a predição de que a câmara "Chapéu Mexicano" traria benefícios em relação ao "Baseline", e a consequente construção do novo pistão, foi feita uma análise experimental comparativa que constatou este fato em um motor de pesquisa FEV;

- A partir do modelo utilizado, já validado e calibrado, é possível utilizá-lo para análises preditivas de novas geometrias de câmaras de combustão. 


\section{PROPOSTAS PARA TRABALHOS FUTUROS}

- Análise experimental da aplicação da câmara de combustão "Chapéu Mexicano" em um motor multicilindrico;

- Criação e avaliação de novas geometrias de câmaras de combustão com o modelo de combustão (CFD) já previamente calibrado;

- Otimização de uma câmara de combustão através da variação discreta de um número limitado de parâmetros e a sistematização de simulações que permitam uma análise de tendência em relação a uma ou mais grandezas de interesse;

- Avaliação, por CFD, da influência do combustível utilizado nos requisitos geométricos das câmaras de combustão;

- Simulação direta dos processos de escoamentos multifásicos, multiespécies e reativos sem o auxílio de modelos, fazendo-se uso de computadores de alto desempenho (“clusters", por exemplo);

- Simulação de câmaras de combustão específicas para otimização do emprego de injeção direta de combustível em motores do ciclo Otto movidos a etanol. 


\section{BIBLIOGRAFIA}

\subsection{BIBLIOGRAFIA REFERENCIADA}

AUTOMOTIVE ENGINEER (1977). v.2, n.6, p.49, dez.

AUTOMOTIVE ENGINEERING (1974). v.82, n.9, p. 53, set.

AUTOMOTIVE ENGINEERING (1987). v.95, n8, p.116-120, ago.

ÁVILA, M. T. (1994). Estudo de motor de combustão interna, do ciclo Otto, movido a etanol previamente vaporizado. São Carlos. Dissertação (mestrado). Escola de Engenharia de São Carlos. Universidade de São Paulo.

BALBINOT, A.; BRUSAMARELLO, V. J. (2007). Instrumentação e fundamentos de medidas. v.2.

BREHM, C.; WHITELOW, J.H. (1999). Air and fuel characteristics in the intake port of a SI engine. SAE paper 1999-01-1491, may.

CARIS, D.F. et al. (1956). Mechanical octanes for higher efficiency. SAE transactions, v.64, p.76-100, junho.

DIGGS (1953). The effect of combustion time on knock in a spark ignition engine. SAE Transactions, v.61, p.402.

FIOCK et al. (1940). Flame speed and energy considerations in a spherical bombs. NACA TR 682

FUJIMOTO, H. et al. (1995). A study on the formation of vertical vortex in the cylinder of an I.C. engine using CFD: Effect of intake valve closing timing. JSAE review, n.16, p.349-355.

FUJIMOTO, M. et al. (2002). Effect of combustion chamber shape on tumble flow, squishgenerated flow and burn rate. JSAE review, n.23, p.291-296. 
GERRISH, H.C.; VOSS, F. (1940). Analysis of cylinder-pressure-indicator diagrams showing effects of mixture strength and spark timing. NACA TN 772, September.

GLUCKSTEIN, M.E.. WALCUTT, C. (1960). End-gas temperature-pressure histories and their relation to knock. SAE paper, june.

HENRY, R.R. (2001). Single-cylinder engine tests of a motor-driven, variable-valve actuator. SAE paper 2001-01-0241, mar.

HEISLER, H. (1995). Advanced engine technology. London, SAE, ISBN 1560917563.

HERON e FELT (1950). Cylinder performance compression ratio and mechanical octane number effects. SAE Transactions, v.4, p.455.

HEYWOOD, J.B. (1988). Internal Combustion Engine Fundamentals. New York. Mc Graw Hill.

JANEWAY, R.N. (1928). Combustion control by cylinder head design. SAE transactions, v.24, p.139-156.

JUDGE, A.W. (1965). Modern Petrol Engines. London. Butler \& Tanner Ltd. First Edition.

LEÃO, R.M. (2002). Etanol (Energia Verde).São Paulo. Instituto de Qualificação Editora Ltda.

LEE, D.W. (1938). A study of air flow in an engine cylinder. NACA TR 653, sep,

LEE, D.W. (1940). The effects of engine speed and mixture temperature on the knocking characteristics of several fuels. NACA TN 767.

LENZ, H.P. (1992). Mixture formation in spark-ignition engines. Springer-Veriag Wien New York, ISBN 3-221-82331-X.

LICHTY, L.C. (1967). Combustion Engine Processes. New York. Mc Graw - Hill.

MALEEV, V.L. (1945). Internal - Combustion Engines (Theory and Design). New York. Mc Graw - Hill. Second Edition.

MARVIN, C.F.; WHARTON, A.; ROEDEN, C.H. (1936). Further studies of flame movement and pressure development in an engine cylinder. NACA TR 556, sep.

METAL LEVE (2002). Informações Técnicas. Metal Leve.

METAL LEVE (2004). Catálogo de Pistões. Metal Leve. 
MOGI, K. et al. (1998). Analysis and avoidance of pré-ignition in S.I. engines. JSAE review, n.19, p.9-14.

OBERT, E.F. (1971). Motores de combustão interna. $2^{\circ}$ edição. Porto Alegre. Editora Globo S.A.

OZASA, T,. SUZUKI, S.; KONDO, H. (1991). Effect of combustion chamber shape on a lean-burn S.I. engine. JSAE review, v.12, n.2, april.

PAGLIUSO, J. D. (2003). Notas de aula da disciplina "Poluição do Ar".

POULOS, S.G.; HEYWOOD, J.B. (1983). The effect of chamber geometry on spark-ignition engine combustion. SAE Technical Paper 830334.

RASSWEILER, G.M.; WITHROW, L.; CORNELIUS, W. (1940). Engine combustion and pressure development. SAE transactions v.46, n.1, jan.

RICARDO, H.R. (1954). The high-speed internal-combustion engine. London and Glasgow, Blackie \& Son Limited, fourth edition.

RINSCHLER, G.L.; ASMUS, T. (1995). Powerplant perspectives: part I. AUTOMOTIVE ENGINEERING. V.103, n.4, p.38.

ROTHROCK, A. M.; SPENCER, R.C. (1939). The influence of direct air flow on combustion in a spark-ignition engine. NACA TR 657, P.313-325, October.

ROTHROCK, A. M.; BIERMANN, A.E. (1940). Correlation of knocking characteristics of fuels in an engine having a hemispherical combustion chamber. NACA TN 768, jul.

SANDERS, J.C.; PETERS, M.D. (1945). The effect of high temperature of the cylinder head on the knocking tendency of an air-cooled engine cylinder. NACA WR E5A29a, feb.

SANTOS, R.F.E. (2000). Análise de um sistema de injeção eletrônica direta de combustível, adaptado em um motor de combustão interna com ignição por centelha. São Carlos. Dissertação (mestrado). Escola de Engenharia de São Carlos. Universidade de São Paulo.

STAN, C. et al. (2001). Internal Mixture Formation and Combustion from Gasoline to Ethanol. SAE technical paper $2001-01-1207$.

SWETT JR., (1949). Spark Ignition of Flowing Gases. NACA RM E9E17, aug.

TAYLOR, C.F. (1962). The effect of cylinder size on detonation and octane requirement. SAE transactions, v.70, p.175-186. 
TAYLOR, C.F. (1976). Análise dos motores de combustão interna. São Paulo, Editora Esgerd Blücher Ltda. v.1 e v.2.

UEDA, T. et al. (1999). Effect of squish área shape on knocking in a four-valve spark ignition engine. SAE paper 1999-01-1494, may.

URUSHIHARA, T. et al. (1996). Effect of swirl and tumble motion on fuel vapor behavior and mixture stratification in lean burn engine. JSAE review, n.17, p.239-244.

WYSZYNSKI, L.P.; STONE, C.R.; KALGHATGI, G.T. (2002). The volumetric efficiency of direct and port injection gasoline engines with different fuels. SAE paper 2002-01-0839, mar.

YAMAGUSHI, K.; YAMAMOTO, H.; SHIRAISHI, T.; OHSUGA, M. (1996). Influence of mixture preparation on HC emission of SI engine with high swirl ratio under cold conditions. JSAE review, n.17, p.107-112.

ZHAO, F. et al. (1999). Automotive spark - ignited direct - injection gasoline engines. Progress in Energy and Combustion Science. V.25, p.437-562.

ZINNER, K. (1939). Engine knock and combustion chamber form. NACA TM 914, V.42, N.9, may. 


\subsection{BIBLIOGRAFIA CONSULTADA}

AVL (2009) Combustion Engines Development, $1^{\mathrm{a}}$ edição, Germany. Vieweg \& Teubner, Wiesbaden.

AYALA, F.; HEYWOOD, J. B. (2007) Lean SI Engines: The role of combustion variability in defining lean limits. SAE Paper 2007-24-0030

BERGMANN, H.K. (1982). A highly efficient alcohol vapor aspirating spark-ignition engine with heat recovery. SAE paper 821190, p.77-87.

BODEN, R. H.; SCHECTER, H. (1944). Dynamics of the inlet system of a four-stroke engine. NACA TN 935. jun.

BOSCH (1999). Gasoline-engine management. $1^{\circ}$ edição. Germany, SAE, 370p.

BOWDITCH, F.W.; STEBAR, R.F. (1958). Autoignition associated with hot starting. SAE transactions, v.66, p.179-192.

FAN, L.; HEITZ, R. (2000) Development of an ignition and combustion model for sparkignition engines. SAE Paper 2000-01-2809.

FERGUSON, C.R. (1986). Internal combustion engines. $2^{\circ}$ edição. New York. John Wiley \& Sons. 543p.

GERTY, M.; HEYWOOD, J. B. (2006) An investigation of gasoline engine knock limited performance and the effects of hydrogen enhancement. SAE Paper 2006-01-0228.

HATTORI, F.; TAKEDA, K.; YAEGASHI, T.; HARADA, A. (1997). Analysis of fuel and combustion behavior during cold starting of SI gasoline engine. JSAE review, n.18, p.351359 , fev.

HITACHI REVIEW. (1986). Power train control system for lean combustion engines. v.35, n.3, p.141-144.

MATTAVI, J.N.; AMANN, C.A. (1980). Combustion Modeling in Reciprocating Engines. New York - London. Plenum Press.

MEYER, R.; HEYWOOD, J. B. (1999) Evaporation of in-cylinder liquid fuel droplets in an SI-Engine: A diagnostic Based modeling study. SAE Paper 1999-01-0567.

MITTAL, V.; REVIER, B. M.; HEYWOOD, J. B. (2007) Phenomena that determine knock onset in spark-ignition engines. SAE Paper 2007-01-0007. 
RICARDO, H.R. (1931). The high-speed internal-combustion engine. London and Glasgow, Blackie \& Son Limited, second edition.

ZHAO, F. (2002) Automotive Gasoline Direct Injection Engines. SAE. 